DOE/RL-91-28

Revision 1

UC- 630,721

\title{
Hanford Facility Dangerous Waste Permit Application, General Information
}

Dete Published

May 1993

\section{DISCLAIMER}

This report was prepared as an account of work sponsored by an agency of the United States Government. Neither the United States Government nor any agency thereof, nor any of their employees, makes any warranty, express or implied, or assumes any legal liability or responsibility for the accuracy, completeness, or usefulness of any information, apparatus, product, or process disclosed, or represents that its use would not infringe privately owned rights. Reference herein to any specific commercial product, process, or service by trade name, trademark, manufacturer, or otherwise does not necessarily constitute or imply its endorsement, recommendation. or favoring by the United States Government or any agency thereof. The views an! opinions of authors expressed herein do not necessarily state or reflect those of the United States Government or any agency thereof.

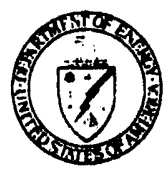

United States

Department of Energy

P.O. Box 550

Richland, Washington 99352 
TRADEMARK DISCLAIMER

Reference herein to any specific commercial product, process, or service by trade name, trademark, manufacturer, or otherwise, does not necessarily constitute or imply its endorsement, recommendation, or favoring by the United States Government or any agency thereof or its contractors or subcontractors.

This report has been reproduced from the best available copy. Available in paper copy and microfiche.

Available to the U.S. Department of Energy

and its contractors from

Office of Scientific and Technical Information

P.0. Box 62

Oak Ridge, TN 37831

(615) 576.8401

Available to the public from the U.S. Department of Commerce National Technical Information Service

5285 Port Royal Road

Springfield, VA 22161

(703) $487-4650$

Printed in the United States of America

DISCLM-5.CHP (8-91) 
DOE/RL-91-28, Rev. 1

$05 / 28 / 93$

\author{
HANFORD FACILITY \\ DANGEROUS WASTE PERMIT APPLICATION, \\ GENERAL INFORMATION
}

FOREWORD

The Hanford Facility is owned by the U.S. Government and operated by the U.S. Department of Energy, Richland Operations Office. Dangerous waste and mixed waste (containing both radioactive and dangerous components) are produced and managed on the Hanford Facility. The dangerous waste is regulated in accordance with the Resource Conservation and Recovery Act of 1976 and the State of Washington Hazardous Waste Management Act of 1976 [as administered through the Washington State Department of Ecology Dangerous Waste Regulations, Washington Administrative Code 173-303]. The radioactive component of mixed waste is interpreted by the U.S. Department of Energy to be regulated under the Atomic Energy Act of 1954; the nonradioactive dangerous component of mixed waste is interpreted to be reguiated under the Resource Conservation and Recovery Act of 1976 and Washington Administrative Code 173-303.

For purposes of the Resource Conservation and Recovery Act and the Washington State Department of Ecology Dangerous Waste Regulations, the Hanford Facility is considered to be a single facility. The single dangerous waste permit identification number issued to the Hanford Facility by the U.S. Environmental Protection Agency and the Washington State Department of Ecology is U.S. Environmental Protection Agency/State Identification Number WA7890008967. As of March 15, 1993, this identification number encompasses 64 interim status treatment, storage, and/or disposal units. Present plans are that final status will be sought for 24 of these 64 interim status treatment, storage, and/or disposal units. Thirty-four units will be closed under interim status and will not be covered by a final status permit. Six units will be dispositioned through other regulatory options. Future circumstances may cause this number to change.

In Section 6.2, the Hanford Federal Facility Agreement and Consent Order (Ecology et al. 1992) addresses the agreement of the parties regarding the treatment, storage, and/or disposal permitting process for the Hanford Facility as follows:

"The Hanford Site has been assigned a single identification number for use in [the] State Dangerous Waste Program/RCRA [Resource Conservation and Recovery Act] permitting activity. Accordingly, the Hanford Site is considered to be a single RCRA facility, although there are numerous unrelated units spread over large geographic areas on the site.

Since all of the TSD [treatment, storage, and/or disposal] groups/units cannot be permitted simultaneously, Ecology [Washington State Department of Ecology] and the EPA [U.S. Environmental Protection Agency] will issue the initial 
permit for less than the entire facility. This permit will eventually grow into a single permit for the entire Hanford Site. Th. Federal authority to issue a permit at a facility in this manner is found in 40 CFR [Code of Federal Regulations] 270.1(c)(4). Any units that are not included in the initial permit will normally be incorporated through a permit modification."

It is the intent of the Hanford Federal Facility Agreement and Consent Order (Ecology et al. 1992) that the initial Hanford Facility Dangerous waste Permit be issued for one or more individual treatment, storage, and/or disposal units for which the application is complete, while all other treatment, storage, and/or disposal units would continue to be regulated under interim status requirements. Activities and areas outside of treatment, storage, and/or disposal units would not be subject to coverage. In satisfaction of the Hanford Federal Facility Agreement and Consent Order (Ecology et al. 1992) Milestone M-20 schedule, Part B permit application documentation has been submitted for several Hanford Facility treatment, storage, and/or disposal units. Upon written notification of completeness from the U.S. Environmental Protection Agency and the Washington State Department of Ecology, one or more of these final, certified documents, along with this document (number DOE/RL-91-28), constitute a complete Dangerous Waste Permit Application meeting all requirements of the Hanford Federal Facility Agreement and Consent Order (Ecology et a1. 1992), 40 Code of Federal Regulatioris 270.1(c)(4), and Washington Administrative Code 173-303-806.

In accordance with the preceding discussion, the current Hanford Facility Dangerous Waste Permit Application is considered to be a single application organized into a General Information Portion (this document, number $D O E / R L-91-28$ ) and a treatment, storage, and/or disposal Unit-Specific Portion, which includes documentation for individual TSD units (e.g., document numbers $\mathrm{DOE} / \mathrm{RL}-89-03$ and $\mathrm{DOE} / \mathrm{RL}-90-01)$. Both portions consist of a Part A division and $a$ Part $B$ division. The Part $B$ division consists of 15 chapters that address the content of the Part $B$ checklists prepared by the Washington State Department of Ecology (Ecology 1987) and the U.S. Environmental Protection Agency (40 Code of Federal Regulations 270), with additional information requirements mandated by the Hazardous and Solid Waste Amendments of 1984 and revisions of Washington Administrative Code 173-303. For ease of reference, the Washington State Department of Ecology checklist section numbers, in brackets, follow the chapter headings and subheadings. Documentation contained in the General Information Portion (i.e., this document, number $\mathrm{DOE} / \mathrm{RL}-91-28$ ) is broader in nature and applies to all treatment, storage, and/or disposal units for which final status is sought. Because of its broad nature, the Part $A$ division of the General Information Portion references the Hanford Facility Dangerous Waste Part A Permit Application (document number DOE/RL-88-21), a compilation of all Part A documentation for the Hanford Facility.

'Dangerous Waste', as used in the title of the Hanford Facility Dangerous Wasie Permit Application, refers to waste subject to Washington Administrative Code 173-303 requirements and to requirements of the Hazardous and Solid Waste Amendments of 1984 for which Washington State has not yet been granted 
authority by the U.S. Environmental Protection Agency. The scope of this permit application includes only those treatment, storage, and/or disposal units for which final status is sought. Furthermore, non-treatment, storage, and/or disposal units, activities, and areas are not included. Once the initial Hanford Facility Dangerous Waste Permit is issued, the
following process will be used. As final, certified treatment, storage, and/or disposal unit-specific documents are developed, and completeness notifications are made by the U.S. Environmental Protection Agency and the 10 Washington State Department of Ecology, additional unit-specific permit

11 conditions will be incorporated into the Hanford Facility Dangerous Waste

12 Permit through the permit modification process. All treatment, storage, 13 and/or disposal units that are included in the Hanford Facility Dangerous

14 Waste Permit Application will operate under interim status until final status

15 conditions for these units are incorporated into the Hanford Facility

16 Dangerous Waste Permit.

This Hanford Facility Dangerous Waste Permit Application, General

Information submittal contains information current as of Harch 15, 1993. 
$G \mapsto \omega N$

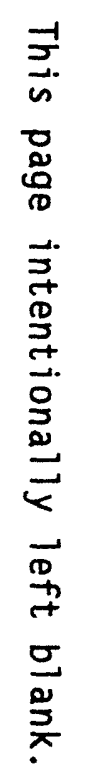

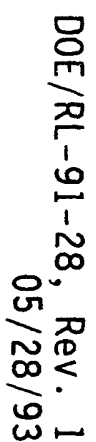




\section{DOCUMENT CONTENTS}

FOREWORD

ACRONYMS AND ABBREVIATIONS

PART A

PART B

1.0 INTRODUCTION

2.0 FACILITY DESCRIPTION AND GENERAL PROVISIONS [B]

3.0 WASTE CHARACTERISTICS [C]

4.0 PROCESS INFORMATION [D]

5.0 GROUNDWATER MONITORING [E]

6.0 PROCEDURES TO PREVENT HAZARDS [F]

7.0 CONTINGENCY PLAN [G]

8.0 PERSONNEL TRAINING [H]

9.0 EXPOSURE INFORMATION REPORT

10.0 WASTE MINIMIZATION

11.0 CLOSURE AND POSTCLOSURE REQUIREMENTS [I]

12.0 REPORTING AND RECORDKEEPING

13.0 OTHER RELEVANT LAWS [J]

14.0 CERTIFICATION [K]

15.0 REFERENCES

\section{APPENDICES}

IA SOLID WASTE MANAGEMENT UNITS

1B GLOSSARY OF TECHNICAL TERMS

2A LOCATION MAPS

2B HANFORD FACILITY LEGAL DESCRIPTION

7A HANFORD FACILITY CONTINGENCY PLAN 
DOE.RL-91-28, Rev. 1

$05 / 28 / 93$

This page intentionally left blank. 


\section{ACRONYMS AND ABBREVIATIONS}

ANOVA

CERCLA

CFR

DOE

DOE-RL

DST System

${ }^{\circ} \mathrm{C}$

Ecology

EII

EPA

FFTF

Hanford Facility Permit

HEIS

HEPA

$M$

MEMO

PARCC (parameters)

Part A

Part B

$\mathrm{pH}$

PUREX

RCRA

SWL

SWMU

TOC

TOX

Tri-Party Agreement

TSD

Unit-Specific Portion analysis of variance

Comprehensive Environmental Response, Compensation, and Liability Act of 1980

Code of Federal Regulations

U.S. Department of Energy

U.S. Department of Energy, Richland Operations Office

Double-Shell Tank System

degree Celsius

degree Fahrenheit

Washington State Department of Ecology

environmental investigation instructions

U.S. Environmental Protection Agency

Fast Flux Test Facility

Hanford Facility Dangerous Waste Permit

Hanford Environmental Information System

high-efficiency particulate air filter

milestone

monitoring efficiency model

precision, accuracy, representativeness, completeness, and comparability

Dangerous Waste Part A Permit Application

Dangerous Waste Part $B$ Permit Application

negative logarithm of the hydrogen-ion concentration

plutonium-uranium extraction

Resource Conservation and Recovery Act of 1976

solid waste landfill

solid waste management unit

total organic carbon

total organic halogen

Hanford Federal Facility Agreement and Consent Order

treatment, storage, and/or disposal

TSD Unit-Specific Portion 
ACRONYMS AND ABBREVIATIONS (cont)

WAC

WIDS

WPPSS

WRAP

Washington Administrative Code Waste Information Data System Washington Public Power Supply System Waste Receiving and Processing 
DOE/RL-91-28, Rev. 1 $05 / 28 / 93$

PART A

The Hanford Facility is a single treatment, storage, and/or disposal facility consisting of, as of March 15, 1993, 64 interim status treatment, storage, and/or disposal units. The single dangerous waste permit identification number issued to the Hanford Facility by the U.S. Environmental Protection Agency and the Washington State Department of Ecology is U.S. Environmental Protection Agency/State Identification Number WA7890008967.

The current Hanford Facility Dangerous Waste Part A Permit Application [document number DOE/RL-88-21 (DOE-RL 1988b)] consists of two "Dangerous Waste Permit General Information, Form 1s" (submitted at the facility level) and 63 "Dangerous Waste Permit Application, Form $3 \mathrm{s"} \mathrm{(submitted} \mathrm{at} \mathrm{the} \mathrm{unit} \mathrm{level;}$ in one instance, two units are covered by one Form 3). The Hanford Facility Dangerous Waste Part A Permit Application consolidates into a single controlled document the current revisions of all Hanford Facility Part $A$ Permit Application Form $1 \mathrm{~s}$ and Form $3 \mathrm{~s}$ submitted to the U.S. Environmental Protection Agency and the Washington State Department of Ecology. Thus, the contents of this document have not been reproduced for inclusion in the Part $A$ division of the Hanford Facility Dangerous Waste Permit Application, General Information.

The Hanford Facility Dangerous Waste Part A Permit Application was designed to facilitate the insertion of revised material and will be revised in the future, as needed, to ensure compliance with applicable regulations. A11 revisions to Part $A$ permit application Form $3 \mathrm{~s}$ for treatment, storage, and/or disposal units operating under interim status will be carried out in accordance with the requirements of the Washington State Department of Ecology Dangerous Waste Regulations, Washington Administrative Code 173-303-805(7).

The 64 interim status treatment, storage, and/or disposal units within the Hanford Facility Dangerous Waste Part A Permit Application include, but are not limited to, tank systems, surface impoundments, container storage areas, waste piles, landfills, and miscellaneous units. Present plans are that final status will be sought for 24 of these 64 interim status treatment, storage, and/or disposal units. Thirty-four units will be closed under interim status and will not be covered by a final status permit. Six units will be dispositioned through other regulatory options. Future circumstances may cause this number to change.

The scope of the Hanford Facility Dangerous Waste Permit Apolication includes only those Hanford Facility treatment, storage, and/or disposal units for which final status is sought. Thus, only Part A permit applications for units for which final status is sought are included in this Part A division, by reference to the Hanford Facility Dangerous Waste Part A Permit

Application. 
D0E/RL-91-28, Rev. 1

$05 / 28 / 93$

This page intentionally left blank. 
DOE/RL-91-28, Rev. 1

$05 / 28 / 93$

\section{PART B}

4 The Hanford Facility Dangerous Waste Part B Permit Application, General
5 Information consists of 15 chapters and 5 appendices. 


\section{DOE/RL-91-28, Rev. 1 \\ $05 / 28 / 93$}

$$
\begin{aligned}
& 1 \\
& 2 \\
& 3 \\
& 4 \\
& 5
\end{aligned}
$$

This page intentionally left blank. 


\section{CONTENTS}

1.0 INTRODUCTION ........................ . . . . . .

1.1 HANFORD FACILITY PERMITTING . . . . . . . . . . . . . . . 1-1

1.1.1 ReguTatory Basis and Scope . . . . . . . . . . . . 1-1

1.1.2 Role of Hanford Federal Facility Agreement

and Consent Order ............... . . 1-1

1.1.3. Role of Hanford Facility Dangerous Waste Permit

Application ................. 1-3

1.1.4 Relationship Between the Hanford Federal Facility

Agreement and Consent Order and the Hanford

Facility Dangerous Waste Permit . . . . . . . . 1-4

1.1.5 Sol id Waste Management Units .......... 1-5

1.2 THE HANFORD FACILITY DANGEROUS WASTE PART B PERMIT

APPLICATION, GENERAL INFORMATION CONTENTS ........... . 1-5

1.2.1 Facility Description and General Provisions . . . . . . 1-6

1.2.2 Waste Characteristics . . . . . . . . . . . . 1-6

1.2.3 Process Information ................ . 1-6

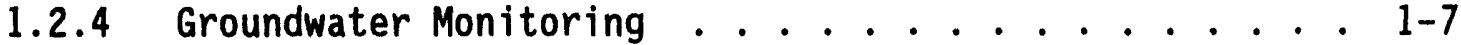

1.2.5 Procedures to Prevent Hazards . . . . . . . . . . . . 1-7

1.2.6 Contingency Plan ................. 1-7

1.2.7 Personnel Training ................ . 1-7

1.2.8 Exposure Information Report . . . . . . . . . . . 1-7

1.2.9 Waste Minimization .. . . . . . . . . . . . . . 1-7

1.2.10 Closure and Postclosure Requirements . . . . . . . . 1-7

1.2.11 Reporting and Recordkeeping ... . . . . . . . . . . 1-8

1.2.12 Other Relevant Laws . . . . . . . . . . . . . . . 1-8

1.2.13 Certification ................... 1-8

1.2.14 References . . . . . . . . . . . . . . 1-8

1.3 ACRONYMS AND ABBREVIATIONS . . . . . . . . . . . . . 1-8

1.4 DEFINITIONS . . . . . . . . . . . . . . . . . . 1-8

1.5 PERMIT MODIFICATIONS . . . . . . . . . . . . . 1-10

IA SOLID WASTE MANAGEMENT UNITS ................ APP 1A- $i$ 
DOE/RL-91-28, Rev. 1

$05 / 28 / 93$

1

FIGURES

4 1-1. Permitting Process Flowchart . . . . . . . . . . . . . . . . F1-1

5 1-2. Organization of the Hanford Facility Dangerous Waste Permit

6 Application ................... . . Fl-2

7 


\subsection{INTRODUCTION}

This chapter describes the permitting approach for the Hanford Facility and provides an overview of the contents of the Hanford Facility Dangerous Waste Part B Permit Application, General Information.

\subsection{HANFORD FACILITY PERMITTING}

This section describes the permitting approach for the Hanford Facility.

\subsubsection{Regulatory Basis and Scope}

The Hanford Facility is owned by the U.S. Government and operated by the U.S. Department of Energy, Richland Operations Office (DOE-RL). Dangerous waste and mixed waste (containing both radioactive and dangerous components) are produced and managed on the Hanford Facility. The dangerous waste is regulated in accordance with the Resource Conservation and Recovery Act (RCRA) of 1976 and the State of Washington Hazardous Waste Management Act of 1976 [as administered through the Washingtun State Department of Ecology (Ecology) Dangerous Waste Regulations, Washington Administrative Code (WAC) 173-303]. The radioactive component of mixed waste is interpreted by the U.S. Department of Energy to be regulated under the Atomic Energy Act of 1954; the

nonradioactive dangerous component of mixed waste is interpreted to be regulated under the RCRA and WAC 173-303.

For purposes of the RCRA and WAC 173-303, the Hanford Facility is considered to be a single facility. The single dangerous waste permit identification number issued to the Hanford Facility by the U.S. Environmental Protection Agency (EPA) and Ecology is EPA/State Identification Number WA7890008967. As of March 15, 1993, this single EPA/State identification number encompasses 64 interim status treatment, storage, and/or disposal (TSD) units on the Hanford Facility. These TSD units include, but are not limited to, tank systems, surface impoundments, container storage areas, waste piles, landfills, and miscellaneous units. Present plans are that final status will be sought for 24 of these 64 interim status TSD units. Thirty-four units will be closed under interim status and will not be covered by a final status permit. Six units will be dispositioned through other regulatory options. Future circumstances may cause this number to change. The scope of this permit application is limited to those Hanford Facility TSD units for which final status is sought. Also, the scope of this permit application does not address radionuclides (i.e., source, special, and byproduct nuclear material) because radionuclides are not subject to the RCRA or WAC 173-303 regulations.

\subsubsection{Role of Hanford Federal Facility Agreement and Consent Order}

The Hanford Federal Facility Agreement and Consent Order (Tri-Party Agreement) (Ecology et al. 1992) is the legal document covering Hanford Site 
environmental compliance and restoration and remediation activities. Purposes of the Tri-Party Agreement as related to permitting include the following:

- To provide a framework for permitting TSD units and to promote an orderly, effective investigation and cleanup of contamination on the Hanford Site

- To ensure compliance with the RCRA and the State of Washington Hazardous Waste Management Act for TSD units, including requirements covering permitting, compliance, closure, and postclosure care

- To establish a procedural framework and schedule for developing, prioritizing, implementing, and monitoring appropriate response actions on the Hanford Site in accordance with the Comprehensive Environmental Response, Compensation, and Liability Act (CERCLA) of 1980, the National Contingency Plan, the Superfund guidance and policy, RCRA, and RCRA guidance and policy

- To minimize the duplication of analysis and documentation

- To promote the coordination and integration of TSD unit closures with the remediation of surrounding past-practice waste management units.

The Action Plan for Implementation of the Tri-Party Agreement (Tri-Party Agreement Action PIan), an enforceable part of the Tri-Party Agreement, establishes the methods and procedures, and establishes the plans for (1) compliance, permitting, and closure under the RCRA and the Washington State Hazardous Waste Management Act and (2) cleanup of the Hanford Site under CERCLA and RCRA corrective action provisions. Within the Tr -Party Agreement Action Plan, Section 2.4 includes the identification of major milestones established to achieve compliance with the RCRA and the Ecology dangerous waste program TSD requirements. Such milestones $(M)$ include those for submittal of permit applications $(M-20-00)$, installation of RCRA groundwater monitoring wells $(M-24-00)$, and RCRA past-practice site investigations and remedial actions. Schedules for these milestones are contained in the Tri-Party Agreement Action Plan; schedule changes will be made in accordance with Article XL of the Tri-Party Agreement.

In Section 6.2 of the Tri-Party Agreement Action Plan, the Tri-Party Agreement addresses the agreement of the parties regarding the TSD permitting process for the Hanford Facility as follows:

"The Hanford Site has been assigned a single identification number for use in [the] State Dangerous Waste Program/RCRA permitting activity. Accordingly, the Hanford Site is considered to be a single RCRA facility, although there are numerous unrelated units spread over large geographic areas on the site.

Since all of the TSD groups/units cannot be permitted simultaneously, Ecology and the EPA will issue the initial permit for less than the entire facility. This permit will eventually grow into a single permit for the entire Hanford Site. The Federal 
D0E/RL-91-28, Rev. 1

$05 / 28 / 93$

authority to issue a permit at a farility in this manner is found in 40 CFR 270.1(c)(4). Any units that are not included in the initial permit will normally be incorporated through a permit modification."

It is the intent of the Tri-Party Agreement that the initial Hanford Facility Dangerous Waste Permit (Hanford Facility Permit) be issued for one or more individual TSD units for which the application is complete, while all other TSD units would continue to be regulated under interim status requirements. Activities and areas outside of TSD units would not be subject to coverage. In satisfaction of the Tri-Party Agreement Milestone $M-20$ schedule, Part B permit application documentation has been submitted for several Hanford Facility TSD units. Upon written notification of completeness from the EPA and Ecology, one or more of these final, certified documents, along with this document (DOE/RL-91-28), constitute a complete Dangerous Waste Permit Application meeting all requirements of the Tri-Party Agreement, 40 CFR 270.1(c)(4), and WAC 173-303-806.

The TSD unit permitting process is outlined in Sections 6.2 of the Tri-Party Agreement Action Plan. Figure 1-1 depicts a flowchart for processing all dangerous waste permitting documentation for TSD units for which final status is sought. As stated in Section 6.3 of the Tri-Party Agreement Action PIan, there are TSD units that are no longer operating that will be closed under interim status. For these units, interim status closure and postclosure plans will be developed using final status standards as described in WAC 173-303-610 and in accordance with Section 5.3 of the Tri-Party Agreement Action P1an. Because these TSD units are being closed separately under interim status, these TSD units are not addressed in this permit application.

The closure process for TSD units is described in Section 6.3 of the Tri-Party Agreement Action Plan. In some cases, it might be possible to remove dangerous waste and waste constituents associated with a TSD unit to Hanford Site background levels and thereby achieve 'clean closure'. If the waste constituents are at or below a health-based standard level, the TSD unit will be considered closed and no further closure activities are required. If health-based closure cannot be achieved, the TSD unit will be closed as a landfill. The process to close any unit as a landfill will be carried out in accordance with al1 applicable requirements described in WAC 173-303.

In the case of closure as a landfill, postclosure permit application documentation will be required. This documentation will cover maintenance and inspection activities, groundwater monitoring requirements, and corrective actions, if necessary, that will occur during the postclosure period.

\subsubsection{Role of Hanford Facility Dangerous Waste Permit Application}

In accordance with the discussions in Sections 1.1 .1 and 1.1 .2 , the current Hanford Facility Dangerous Waste Permit Application is considered to be a single application organized into a General Information Portion (this document, number DOE/RL-91-28) and a TSD Unit-Specific Portion (Unit-Specific Portion), which includes documentation for individual TSD units 
(e.g., document number DOE/RL-89-03 and DOE/RL-90-01) (Figure 1-2). Both portions consist of a Part $A$ division and a Part B division. The Part $B$ division consists of 15 chapters that address the content of the Part $B$ checklists prepared by Ecology (Ecology 1987) and the EPA (40 CFR 270), with additional information requirements mandated by the Hazardous and Solid Waste Amendments of 1984 and revisions of WAC 173-303. For ease of reference, the Ecology checklist section numbers, in brackets, follow the chapter headings and subheadings. Documentation contained in the General Information Portion (i.e., this document, number DOE/RL-91-28) is broader in nature and applies to all TSD units for which final status is sought. Because of its broad nature, the Part A division of the General Information Portion references the Hanford Facility Dangerous Waste Part A Permit Application (document number DOE/RL-88-21), a compilation of all Part A documentation for the Hanford Facility.

'Dangerous Waste', as used in the title of the Hanford Facility Dangerous Waste Permit Application, refers to waste subject to WAC 173-303 requirements and to requirements of the Hazardous and Solid Waste Amendments for which Washington State has not yet been granted authority by the EPA. The scope of this application includes only those TSD units for which final status is sought. Non-TSD units, activities, and areas are not included.

Once the initial Hanford Facility Permit is issued, the following process will be used. As final, certified TSD unit-specific documents are developed, and completeness notifications are made by the EPA and Ecology, additional unit-specific permit conditions will be incorporated into the Hanford Facility Permit through the permit modification process. These additions will be conducted as specified in Section 1.5, which addresses the permit modification process. All TSD units that are included in the Hanford Facility Dangerous Waste Permit Application will operate under interim status unt il final status conditions for these units are incorporated into the Hanford Facility Permit.

\subsubsection{Relationship Between the Hanford Federal Facility Agreement and Consent Order and the Hanford Facility Dangerous Waste Permit}

In accordance with the Tri-Party Agreement, ine Hanford Facility will undergo changeover from interim status to final +atus on a unit-by-unit basis. The proposed approach is provided in the following paragraph.

The initial Hanford Facility Permit will be developed in accordance with the Tri-Party Agreement, WAC 173-303, and the RCRA. Dangerous waste activities at TSD units receiving 'final administrative disposition' will be incorporated into permit conditions and will be subject to final facility standards. For example, if the 616 Nonradioactive Dangerous Waste Storage Facility is included in the initial permit, activities at this storage unit will be subject to final facility standards. Other interim status TSD units not included in the initial Hanford Facility Permit will continue to qualify for interim status pursuant to Section 3005 of the RCRA until included in a subsequent modification of the Hanford Facility Permit. Non-TSD units, activities, and areas are not included. 
DOE/RL-91-28, Rev. 1 $05 / 28 / 93$

Appeals from the Hanford Facility Permit will be managed under WAC 173-303-845, or other applicable law, except for those appeals that are governed by the Tri-Party Agreement dispute resolution provisions of Articles VIII and XV or the enforceability provisions of Articles IX and XX, as appropriate. Where there is a potential conflict between the Tri-Party Agreement and the Hanford Facility Permit, the wording of the Tri-Party Agreement will prevail and conflicts between the Tri-Party Agreement and the Hanford Facility Permit will be resolved under Part Four of the Tri-Party Agreement. This approach will enable the DOE-RL and its contractors to follow the Tri-Party Agreement without concern that adherence to the Tri-Party Agreement could result in a violation of the Hanford Facility Permit.

Article I, Paragraph 5 of the Tri-Party Agreement governs any assertion of inconsistency with the Atomic Energy Act. Article XXIV, Paragraphs 79 and 80 of the Tri-Party Agreement, addresses Physically Inconsistent Action provisions.

Ecology and the EPA or their authorized representatives will enter the Hanford Site in accordance with WAC 173-303-960(2)(a) and Articles XXXVII of the Tri-Party Agreement. The specifics of entry prutocol will be defined in a DOE-RL Hanford Site access protocol document. Classified and confidential information will be handled in accordance with Article XLV of the Tri-Party Agreement.

\subsubsection{Solid Waste Management Units}

A solid waste management unit (SWMU) is "any discernable unit at which solid waste has been placed at any time, irrespective of whether the unit was intended for the management of solid or hazardous waste. Such units include any area at a facility at which solid waste routinely and systematically has been released [40 CFR 264.501 (proposed)]." A discussion of SWMUs on the Hanford Facility is provided in Appendix 1A. The Tri-Party Agreement outlines the approach for addressing SWMUs on the Hanford Facility.

\subsection{HANFORD FACILITY DANGEROUS WASTE PART B PERMIT APPLICATION, GENERAL INFORMATION CONTENTS}

This section provides an overview of the Hanford Facility Part B Permit Application, General Information contents. This $\mathrm{Pa}+\mathrm{B}$ permit application portion consists of 15 chapters that address the conients of the Part $B$ checklists prepared by Ecology (Ecology 1987) and the EPA (40 CFR 270), with additional information requirements mandated by the Hazardous and Solid Waste Amendments and revisions of WAC 173-303. For ease of reference, the Ecology checklist section numbers, in brackets, follow the chapter headings and subheadings. 
The Hanford Facility Part B Permit Application, General Information consists of the following 15 chapters:

- Introduction (Chapter 1.0)

- Facility Description and General Provisions (Chapter 2.0)

- Waste Characteristics (Chapter 3.0)

- Process Information (Chapter 4.0)

- Groundwater Monitoring (Chapter 5.0)

- Procedures to Prevent Hazards (Chapter 6.0)

- Contingency Plan (Chapter 7.0)

- Personnel Training (Chapter 8.0)

- Exposure Information Report (Chapter 9.0)

- Waste Minimization (Chapter 10.0)

- Closure and Postclosure Requirements (Chapter 11.0)

- Reporting and Recordkeeping (Chapter 12.0)

- Other Relevant Laws (Chapter 13.0)

- Certification (Chapter 14.0)

- References (Chapter 15.0).

A brief description of each chapter is provided in the following sections. These chapters contain information that is common to all TSD units for which final status is sought.

\subsubsection{Facility Description and General Provisions (Chapter 2.0)}

This chapter provides a general description of the Hanford Facility. This chapter also contains a discussion of performance standards, spill management, manifesting, and the quality assurance and quality control program.

\subsubsection{Waste Characteristics (Chapter 3.0)}

This chapter briefly addresses the physical, chemical, and biological characteristics of the waste types treated, stored, and/or disposed of on the Hanford Facility. Reference is made to the contents of the Hanford Facility Dangerous Waste Part A Permit Application (DOE-RL 1988b) for waste characteristics information. This chapter also includes a brief overview of TSD unit-specific waste analysis plans and a discussion of the handling of land disposal restricted waste.

\subsubsection{Process Information (Chapter 4.0)}

This chapter provides a general discussion of the design, construction, and operation of TSD units within the Hanford Facility for which final status is sought. This chapter also provides a discussion of the handling of design information related to permitting considerations. 


\subsubsection{Groundwater Monitoring (Chapter 5.0)}

This chapter discusses the hydrogeologic characteristics of the Hanford Facility. This chapter also provides a general overview of the activities and objectives common to groundwater monitoring programs for TSD units within the Hanford Facility for which final status is sought.

\subsubsection{Procedures to Prevent Hazards (Chapter 6.0)}

This chapter discusses hazard prevention and emergency preparedness equipment, structures, and procedures.

\subsubsection{Contingency Plan (Chapter 7.0)}

This chapter provides information on contingency planning to ensure that the Hanford Facility has measures in place to lessen the potential impact on the pub1ic health and the environment in the event of an emergency.

\subsubsection{Personnel Training (Chapter 8.0)}

This chapter provides a brief overview of the activities and objectives common to the training programs for TSD units within the Hanford Facility for which final status is sought.

\subsubsection{Exposure Information Report (Chapter 9.0)}

This chapter provides a brief overview of the criteria that must be considered in evaluating the potential for human exposure from surface impoundment or landfill TSD units within the Hanford Facility for which final status is sought.

\subsubsection{Waste Minimization (Chapter 10.0)}

This chapter discusses the waste minimization requirements for TSD units within the Hanford Facility for which final status is sought.

\subsubsection{Closure and Postclosure Requirements (Chapter 11.0)}

This chapter describes how final status TSD units and the Hanford Facility will be closed, and discusses the interrelationship of RCRA and CERCLA activities related to closure. 
2

3

4

5

6

\section{7}

\subsubsection{Reporting and Recordkeeping (Chapter 12.0)}

This chapter summarizes commitments for reporting and recordkeeping that are applicable to the Hanford Facility.

\subsubsection{Other Relevant Laws (Chapter 13.0)}

This chapter discusses federal, state, and local laws that govern the operation of the Hanford Facility, other than the RCRA, as amended, and the State of Washington Hazardous Waste Management Act, as amended.

\subsubsection{Certification (Chapter 14.0)}

This chapter contains the required certification signed by an official of the DOE-RL (the facility owner/operator) indicating that the information provided is true, accurate, and complete.

\subsubsection{References (Chapter 15.0)}

References used throughout this Part B permit application portion are listed in this chapter. All references listed here, which generally are not available from other sources, will be made available for review upion request to any regulatory agency or public commentor. References can be ubtained by contacting the following:

Administrative Records Specialist

Public Access Room H5-08

West inghouse Hanford Company

P. 0. Box 1970

Richland. Washington 99352

\subsection{ACRONYMS AND ABBREVIATIONS}

Acronyms and abbreviations used throughoul this fart B permit application portion are located at the beginning of the document between the Foreword and the Part A permit application section.

\subsection{DEFINITIONS}

Definitions specific to this permit application are provided in this section. These definitions supplement those provided in WAC 173-303-040.

Contractor-Firm under contract to the U.S. Department of Energy to provide Hanford Site services. Currently, there are the following four Hanford site prime contractors: 
- An Operations and Engineering Contractor

- A Research and Development Contractor

- An Engineer and Construction Contractor

- A Medical and Health Services Contractor.

Throughout the remainder of this permit application portion, the term contractor, except where specified, is used to refer to the oprrations and engineering contractor and the research and development contractor. The use of the word 'operations' in 'operations and engineering contractor' is a contractual term, and is unrelated to the word 'operator' as defined by the RCRA and WAC 173-303.

Dangerous or hazardous waste--In addition to the definition in WAC 173-03-040, means the nonradioactive dangerous component of waste commonly called mixed waste (i.e., waste that is both dangerous and radioactive). Dangerous waste commonly is used to refer to hazardous, dangerous, or extremely hazardous waste within this permit application.

Facility--Dependent on context, the term 'facility', as used in this permit application portion. could refer to:

- The Hanford Facility (refer to definition)

- Building nomenclature commonly used at the Hanford Facility. In this context, the term 'facility' remains as part of the title for various TSD units (e.g., 616 Nonradioactive Dangerous Waste Storage Facility, Grout Treatment Facility)

- For purposes of complying with the RCRA corrective action provisions, all contiguous property under the control of the owner or operator seeking a permit under subtitle $C$ of RCRA.

Generating unit--Term inferred to have the same meaning as 'generator' as defined in WAC 173-303-040. For purposes of the RCRA and the Dangerous Waste Regulations, the Hanford Site is considered to be a single generator comprised of a number of generating units.

Hanford Facility--A single RCRA facility identified by the EPA/State Identification Number WA7890008967 that consists of over 60 TSD units conducting dangerous waste management activities. These TSD units are included in the Hanford Facility Dangerous Waste Part A Permit Application (DOE-RL 1988b). The Hanford Facility consists of the contiguous portion of the Hanford Site that contains these TSD units and, for the purposes of RCRA, is owned by the U.S. Government and operated by the U.S. Department of Energy, Richland Operations Office (excluding lands north and east of the Columbia River, river islands, lands owned or used by the Bonneville Power Administration, lands leased to the Washington Public Power Supply System, and lands owned by or leased to the state of Washington). The physical description of the property (including structures, appurtenances, and improvements) is set forth in Appendix $2 A$. The legal description of the Hanford Facility is set forth in Appendix 2B. 
Hanford Site - The approximately 560 square miles (1,450 square kilometers) in southeastern Washington State owned by the United States Government and sometimes referred to as the Hanford Reservation.

Hazardous waste management unit--Term inferred to have the same meaning as 'dangerous waste management unit' as defined in WAC 173-303-040.

Operable unit--Because of the relatively large number of past-practice units on the Hanford Site, a process has been established for organizing these pastpractice units into groups called operable units. The concept of operable units is to group the numerous units (primarily by geographic area) into manageable components for investigation and remedial action and to prioritize the restoration and remediation work to be done at the Hanford Site (Ecology et al. 1992).

Operator-- The U.S. Department of Energy and its successors.

Past-practice unit--A waste management unit where wastes or substances (intentionally or unintentionally) have been disposed of and that is not subject to regulation as a TSD unit (Ecoiogy et al. 1992).

Reasonable times--Normal business hours; hours during which production, construction, treatment, storage, disposal, or discharge occur.

Treatment, storage, and/or disposal (TSD) unit--A unit used for treatment, storage, and/or disposal of dangerous waste that is required to be permitted and/or closed pursuant to the RCRA and WAC 173-303 requirements as determined in the Tri-Party Agreement Action Plan. Also refers to a grouping of TSD units for the purpose of preparing and submitting permit application documentation pursuant to the requirements under the RCRA and WAC 173-303, as determined in the Tri-Party Agreement Action Plan. Each TSD unit property (including structures, appurtenances, and improvements) for which final status is sought is described in the Unit-Specific Portion of this permit application.

Tri-Party Agreement--The term Tri-Party Agreement means the Hanford Federal Facility Agreement and Consent Order dated May 1989, as amended, and as it may be amended from time to time, including the Tri-Party Agreement Action Plan incorporated in the Tri-Party Agreement.

A glossary of technical terms used within this permit application portion is provided in Appendix $1 B$.

\subsection{PERMIT MODIFICATIONS}

$c$

All modifications to the Hanford Facility Permit will be made in accordance with the requirements identified in WAC 173-303-830, with the following exception. The notifications required by WAC $173-303-830(4)(a)(i)(A)$ and $(B)$ for Class 1 changes will be submitted annually to the required regulatory agencies, appropriate units of state and local government, and individuals on the facility mailing list maintained by 


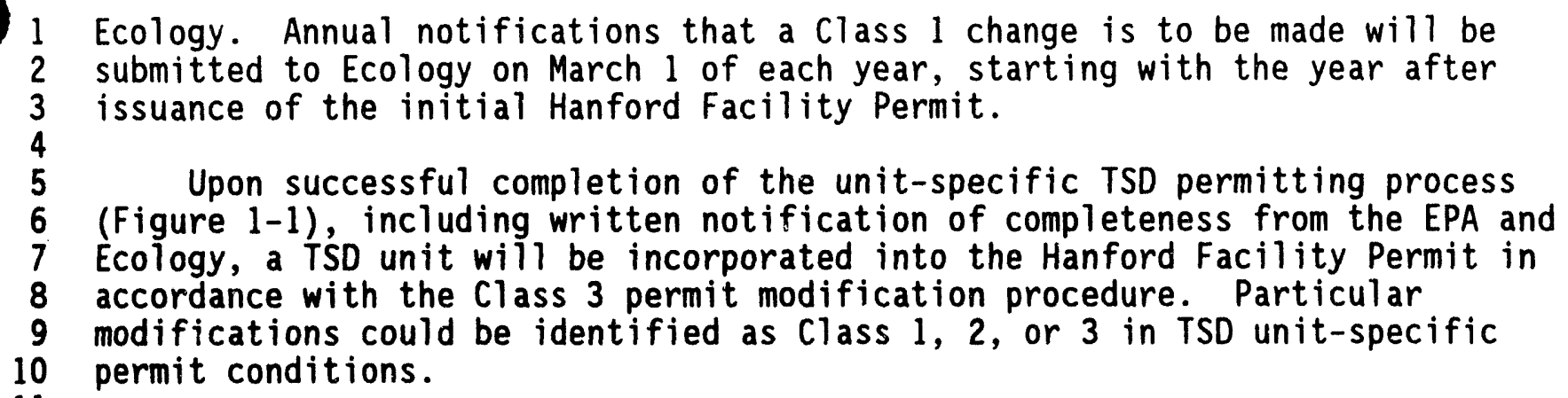
submitted to Ecology on March 1 of each year, starting with the year after issuance of the initial Hanford Facility Permit.

Upon successful completion of the unit-specific TSD permitting process (Figure 1-1), including written notification of completeness from the EPA and Ecology, a TSD unit will be incorporated into the Hanford Facility Permit in accordance with the Class 3 permit modification procedure. Particular modifications could be identified as Class 1,2 , or 3 in TSD unit-specific 10 permit conditions. 


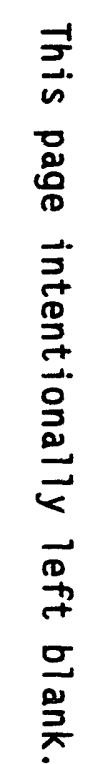




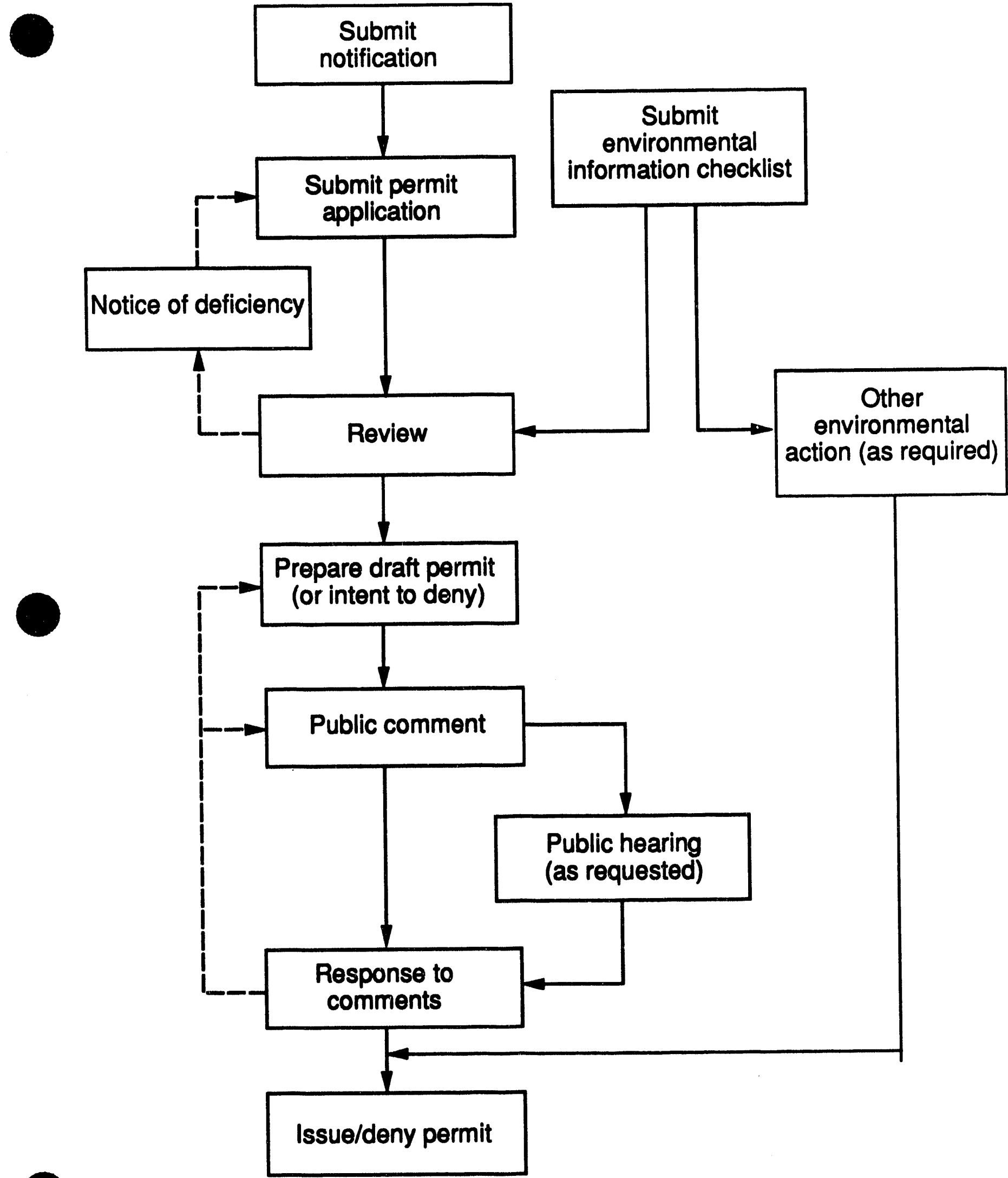

Figure 1-1. Permitting Process Flcwchart. (Ecology et al. 1992) 
DOE/RL-91-28, Rev. 1

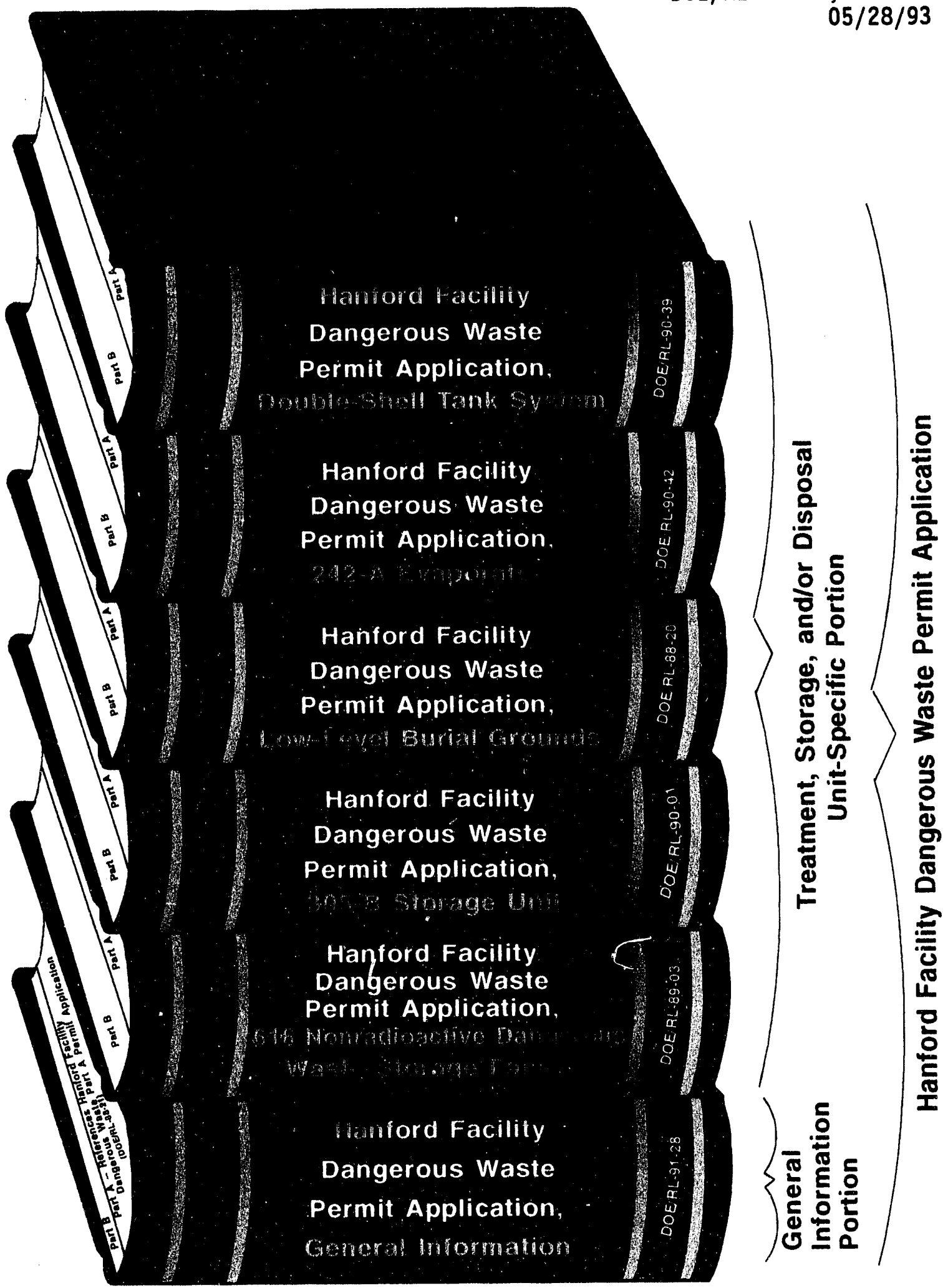

Figure 1-2. Organization of the Hanford Facility Dangerous Waste Permit Application. [Scope: limited to those treatment, storage, and/or disposal units for which final status is sought; not all unit-specific documents are shown. (For illustrative purposes only.)] 


\section{CONTENTS}

2.0 FACILITY DESCRIPTION AND GENERAL PROVISIONS [B] . . . . . . . . . 2-1

2.1 GENERAL DESCRIPTION [B-1] . . . . . . . . . . . . 2-1

2.1.1 The Hanford Site... . . . . . . . . . . . . 2-1

2.1.2 Hanford Facility. . . . . . . . . . . . . . . 2-2

2.1.3 Overview of Waste Management on the Hanford Site . . 2-3

2.1.4 Treatment, Storage, and Disposal Units . . . . . . 2-5

2.1.4.1 200 Areas . . . . . . . . . . . . . 2-5

2.1.4.2 300 Area . . . . . . . . . . . . . 2-5

2.1.4.3 400 Area . . . . . . . . . . . . . . 2-6

2.1.4.4 600 Area . . . . . . . . . . . . . . 2-6

2.2 TOPOGRAPHIC MAP [B-2]................ 2-6

2.3 LOCATION INFORMATION [B-3] . . . . . . . . . . . . 2-7

2.3.1 Seismic Risk Consideration [B-3a] . . . . . . . . . 2-7

2.3.2 Floodplain Standard [B-3b] . . . . . . . . . . . . . 2-7

2.3.2.1 Demonstration of Compliance $[B-3 b(1)] . .2-8$

2.3.2.2 Plan for Future Compliance with

Floodplain Standard $[B-3 b(2)]$. . . . . . 2-8

2.3.3 Shoreline Standard $[B-3 C]$. . . . . . . . . 2-8

2.3.4 Sole Source Aquifer Criteria [B-3d] . . . . . . . 2-8

2.4 TRAFFIC INFORMATION [B-4] . . . . . . . . . . . . . 2-9

2.4.1 Hanford Site Roadways . . . . . . . . . . . . . . . . . 2-9

2.4.2 Traffic Control Signs, Signals, and Procedures . . . . 2-9

2.4.3 Hanford Site Railroad System .. . . . . . . . . 2-10

2.5 PERFORMANCE STANDARDS [B-5] . . . . . . . . . . . . 2-10

2.5.1 Measures to Prevent Degradation of

Groundwater Quality .. . . . . . . . . . . . 2-11

2.5.2 Measures to Prevent Degradation of Air Quality

by Open Burning or Other Activities . . . . . . . . . 2-11

2.5.3 Measures to Prevent Degradation of Surface Water

Quality ...................2-11

2.5.4 Measures to Prevent Destruction or Impairment

of Flora or Fauna Outside of the Treatment,

Storage, and/or Disposal Units . . . . . . . . . 2-11

2.5.5 Measures to Prevent Excessive Noise . . . . . . . . . 2-12

2.5.6 Measures to Prevent Negative Aesthetic Impacts . . . . . 2-12

2.5.7 Measures to Prevent Unstable Hillsides or Soils . . . . 2-12

2.5.8 Measures to Prevent the Use of Processes That

Do Not Treat, Detoxify, Recycle, Reclaim, and

Recover Waste Material to the Extent Economically

Feasible . . . . . . . . . . . . . . . 2-12

2.5.9 Measures to Prevent Endangerment to the Health of

Employees or the Public Near the Hanford Facility . . . 2-12

2.6 BUFFER MONITORING ZONES [B-6] . . . . . . . . . . . 2-13 
2.7 SPILLS AND DISCHARGES INTO THE ENVIRONMENT [B-7] . . . . . . . 2-13

2.7.1 Notification [B-7a] . . . . . . . . . . . 2-13

2.7.2 Mitigation and Control $[B 7-b)$. . . . . . . . . 2-14

2.8 MANIFEST SYSTEM [B-8] . . . . . . . . . . . . . . . . 2-14

2.8.1 Onsite Waste Shipments . . . . . . . . . . . 2-14

2.8.2 Offsite Waste Shipments . . . . . . . . . . . 2-15

2.8.3 Receipt of Offsite Waste............. . 2-15

2.9 QUALITY ASSURANCE AND QUALITY CONTROL PROGRAM FOR

THE HANFORD FACILITY .................. . 2-15

\section{APPENDICES}

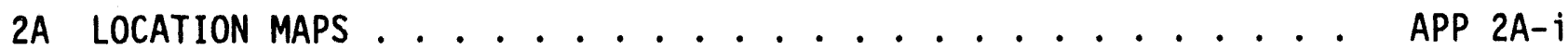

2B HANFORD FACILITY LEGAL DESCRIPTION . . . . . . . . . . . APP 2B-i

\section{TABLE}

2-1. Hanford Site Map ... . . . . . . . . . . . . . . . . . F2-1

2-2. Hanford Facility Map . . . . . . . . . . . . . . . . . . . F2-2

2-3. Prevailing Wind Direction for the Hanford Site . . . . . . . . F2-3

2-4. Columbia River Floodplain (probable maximum flood) . . . . . . . . F2-4

2-5. Yakima River Floodplain . . . . . . . . . . . . . . . . F2-5

2-6. Cold Creek Watershed Floodplain (probable maximum flood) . . . . . F2-6

2-7. Estimated Traffic Volumes (vehicles per day) . . . . . . . . . F2-7 
DOE/RL-91-28, Rev. 1

$05 / 28 / 93$

\subsection{FACILITY DESCRIPTION AND GENERAL PROVISIONS [B]}

This chapter briefly describes the Hanford Site and provides a general overview of the Hanford Facility, including the following:

- General description

- Topography

- Location information

- Traffic information

- Performance standards

- Buffer monitoring zones

- Spills and discharges

- Manifest system

- Quality assurance and quality control.

\subsection{GENERAL DESCRIPTION [B-1]}

As of March 15, 1993, the Hanford Facility consists of 64 interim status TSD units. Present plans are that final status will be sought for 24 of these 64 interim status TSD units. Thirty-four units will be closed under interim status and will not be covered by a final status permit. Six units will be dispositioned through other regulatory options. Future circumstances may cause this number to change.

The 24 TSD units for which final status is sought are involved in dangerous and/or mixed waste activities. Dangerous waste means hazardous, dangerous, or extremely hazardous waste as defined by the RCRA and/or WAC 173-303 (Chapter 1.0, Section 1.4). Mixed waste means waste that contains both hazardous and dangerous waste subject to the RCRA and WAC 173-303, and radioactive waste subject to the Atomic Energy Act (Chapter 1.0, Section 1.4). The radioactive portion of mixed waste can be low-activity, high-activity, and/or transuranic. Because radionuclides are not subject to regulation under the RCRA or WAC 173-303, any discussion of the treatment, storage, and/or disposal of radionuclides in this permit application is included for information only.

The TSD units within the Hanford Facility include, but are not limited to, tank systems, surface impoundments, container storage areas, waste piles, landfills, and miscellaneous units. An overview of the various TSD units within the Hanford Facility for which final status is sought is provided in Chapter 4.0. As noted in Chapter 1.0, TSD units that are undergoing interim status closure are not included in this permit application.

\subsubsection{The Hanford Site}

The Hanford Site covers approximately 560 square miles $(1,450$ square kilometers) of semiarid 1 and that is owned by the U.S. Government and managed by the DOE-RL. The Hanford Site is located northwest of the city of Richland, Washington (Figure 2-1). The city of Richland adjoins the southeastern most 
portion of the Hanford Site boundary and is the nearest population center. In early 1943, the U.S. Army Corps of Engineers selected the Hanford Site as the location for reactor, chemical separation, and related activities for the production and purification of special nuclear materials and other nuclear activities. The mission of the Hanford Site is currently focusing on waste management and environmental restoration and remediation activities.

The Hanford Site is divided into numerically designated areas (Drawing H-6-958 in Appendix 2A). The reactors are located along the Columbia River in the 100 Areas. The reactor fuel reprocessing units are in the 200 Areas, which are on a plateau approximately 7 miles (11 kilometers) from the Columbia River. The 300 Area, located adjacent to and north of Richland, contains the reactor fuel manufacturing plants and the research and development laboratories. The 400 Area, 5 miles ( 8 kilometers) northwest of the 300 Area, contains the Fast Flux Test Facility designed for testing liquid metal reactor systems. The 600 Area covers all locations not specifically given an area designation. Adjacent to and north of Richland, the 1100 Area contains offices associated with administration, maintenance, transportation, and materials procurement and distribution. The 3000 Area, between the 1100 Area and 300 Area, contains engineering offices and administrative offices. Administrative offices also are located in the 700 Area, which is in downtown Richland.

Where general information for the Hanford Site is discussed in this permit application portion, such information also applies to the Hanford Facility, unless otherwise designated.

\subsubsection{Hanford Facility}

The Hanford Facility is defined as a single RCRA facility, identified by the EPA/State Identification Number WA7890008967, that currently contains 64 interim status TSD units. These TSD units are included in the Hanford Facility Dangerous Waste Part A Permit Application (DOE-RL 1988b). The Hanford Facility consists of the contiguous portion of the Hanford Site that contains these TSD units and, for the purposes of the RCRA, is owned by the U.S. Government and operated by the DOE-RL (excluding lands north and east of the Columbia River, river islands, lands owned or used by the Bonneville Power Administration, lands leased to the Washington Public Power Supply System, and lands owned by or leased to the state of Washington). The physical description of the property (including structures, appurtenances, and improvements) is set forth in Appendix $2 A$. The legal description of the Hanford Facility is set forth in Appendix 2B. A map of the Hanford Facility is provided in Figure 2-2.

As noted previously, the Hanford Facility does not include lands owned or used by the Bonneville Power Administration, the lands north and east of the Columbia River, nor lands owned or leased by the state of Washington. The DOE-RL has no control over Bonneville Power Administration lands. The lands north and east of the Columbia River contain no TSD units and are not considered to be contiguous to the Hanford Facility because these lands are separated by the state-owned Columbia River bed. 
In addition, the Washington Public Power Supply System will be applying for a dangerous waste permit for the U.S. Department of Energy lands leased to the Washington Public Power Supply System. These lands will be covered by a separate permit and, therefore, will not be included in the Hanford Facility Permit.

The TSD units to be included in this permit application (i.e., those TSD units for which final status is sought) are limited to the $200,300,400$, and 600 Areas of the Hanford Site. The specific locations of these TSD units are specified in the Hanford Facility Dangerous Waste Part A Permit Application and on maps provided in Appendix $2 A$.

\subsubsection{Overview of Waste Management on the Hanford Site}

In 1989, the U.S. Department of Energy began to redefine the mission at the Hanford Site with a major emphasis on waste management and environmental restoration and remediation programs. Hanford Site work supporting this new mission is outlined in the Draft Environmental Restoration and Waste Management Fiscal Year 1993 Site-Specific Plan of the Richland Field office (DOE-RL 1993). Portions of this plan addressing Hanford Site waste management activities are summarized as follows.

Hanford Site waste management program goals are to decrease the generation of waste and to maintain safe and environmentally sound treatment, storage, and disposal of radioactive waste, dangerous waste, and mixed waste. Most of the waste management activities fall into two major programmatic areas: Tank Waste Remediation System and Solid/Liquid Waste Remediation.

The scope of the Tank Waste Remediation System includes managing all programs, projects, and activities for receiving, safely storing, maintaining, treating, and packaging tank waste for onsite or offsite disposal. Tank waste includes the contents of single-shell tanks and double-shell tanks. The Tank Waste Remediation System currently is conducting rebaselining activities that could cause approaches to waste management to change as program planning proceeds and input is received from stakeholders (e.g., regulators and the public) (WHC 1993b). A brief description of current plans for key TSD units supporting Tank Waste Remediation System is as follows:

- The Double-Shell Tank System--This unit stores and treats radioactive and mixed waste generated on the Hanford Site before final treatment and disposal. The Double-She11 Tank System storage space is maximized through the use of the 242-A Evaporator. Additional tank space is used to support the Hanford Site environmental restoration and remediation mission (e.g., closure of single-shell tanks).

- The 242-A Evaporator--This treatment unit concentrates the doubleshell tank waste by removal of water and volatile and semivolatile organics through evaporation. The concentrated slurry is returned to the Double-Shell Tank System and the process condensate is transferred for storage to the Liquid Effluent Retention Facility. Eventually the 
process condensate will be transferred to the 200 Area Effluent Treatment Facility, once this unit comes online.

- Hanford Waste Vitrification Plant--This unit will treat the high-activity portion of waste stored in the Double-Shell Tank System by converting the waste into glass, with ultimate disposal of the vitrified waste in a national repository.

- Grout Treatment Facility--This unit processes low-activity doubleshell tank waste by combining this waste with grout-forming solids and, if necessary, chemical additives. The grouted waste is disposed of in near-surface concrete vaults.

The scope of the Solid/Liquid Waste Remediation Program includes (1) storing solid waste safely until a disposal decision is reached, (2) providing handling and treatment capabilities for management of solid waste and preparation for final disposal, and (3) eliminating releases of untreated liquid effluents and treating and disposing of liquid waste according to applicable federal and state laws and regulations. A brief description of key TSD units supporting the Solid/Liquid Waste Remediation Program is as follows:

- Central Waste Complex--This treatment and storage unit consists of multiple storage structures (i.e., storage modules, buildings, and a storage pad) for radioactive and/or mixed waste.

- Waste Receiving and Processing--This unit will treat mixed waste, low-level waste, and transuranic waste. The treated transuranic waste eventually will be transported for disposal to the Waste Isolation Pilot Plant in New Mexico (when this plant becomes operational) or to another approved waste disposal site.

- Low-Level Burial Grounds--This unit disposes of solid low-level radioactive waste and mixed waste. Since 1987 , most mixed waste, other than submarine reactor compartments, is being stored at the Central Waste Complex until a lined disposal trench is constructed.

- The 616 Nonradioactive Dangerous Waste Storage Facility--This unit stores nonradioactive dangerous waste before shipment offsite for treatment, storage, and/or disposal.

- The 305-B Storage Unit--This unit stores, bulks, and labpacks dangerous waste before shipment offsite for treatment, storage, and/or disposal. Small-quantities of mixed waste also are stored at the 305-B Storage Unit before being transported to the Central Waste Complex.

- Liquid Effluent Retention Facility--This unit will be used to provide interim storage of mixed waste (process condensate) received from the 242-A Evaporator. The mixed waste will be stored until the 200 Area Effluent Treatment Facility is available. 
- 200 Area Effluent Treatment Facility--This unit will treat mixed waste (process condensate) from the 242-A Evaporator. The treatment process is expected to include filtration, $\mathrm{pH}$ adjustments, ultraviolet light oxidation, reverse osmosis, and ion exchange. Treated effluent will be collected in tanks, sampled to verify that treatment standards have been met, and discharged to the soil column, pending approval of a delisting petition by the EPA and issuance of a State Waste Discharge Permit by Ecology.

The TSD units discussed are, or will be, used to support RCRA closure and CERCLA remediation activities.

\subsubsection{Treatment, Storage, and Disposal Units}

The TSD units for which final status is sought (as of March 15, 1993) are identified in Table 2-1. Also identified in Table 2-1 is the classification of waste management activities conducted at each of these TSD units. Location maps for these TSD units are provided in Appendix 2A. The following sections provide a brief discussion of these TSD units, by area.

2.1.4.1 200 Areas. The 200 Areas are centrally located on the Hanford Site. There are two separate areas, referred to as the 200 East Area and the 200 West Area (Figure 2-2). Underground piping connects the 200 East Area and 200 West Area for purposes of liquid waste transfer. The following TSD units are included in the 200 Areas:

- Double-Shell Tank System

- 242-A Evaporator

- Hanford Waste Vitrification Plant

- Grout Treatment Facility

- 204-AR Waste Unloading Station

- Central Waste Complex

- Waste Receiving and Processing

- Low-Level Burial Grounds

- Liquid Effluent Retention Facility

- 200 Area Effluent Treatmen: Facility

- T Plant Complex

- B Plant

- 241-Z Treatment and Storage Tanks

- 222-S Laboratory Complex

- 224-T Transuranic Waste Storage and Assay Facility

- PUREX (plutonium-uranium extraction) Storage Tunnels.

2.1.4.2 300 Area. The 300 Area is located adjacent to and north of Richland, Washington, along the Columbia River. The 300 Area contains fuels fabrication and research and development buildings for the Hanford Site. The following TSD units are included in the 300 Area:

- 325/3100 Hazardous Waste Treatment Unit

- Biological Treatment Test Facilities

- Physical/Chemical Treatment Test Facilities 
$\mathrm{DOE} / \mathrm{RL}-91-28$, Rev. 1

$05 / 28 / 93$

- Thermal Treatment Test Facilities

- 305-B Storage Unit.

2.1.4.3 400 Area. The 400 Area is located approximately 5 miles

(8 kilometers) northwest of the 300 Area and contains the experimental nuclear reactor, Fast Flux Test Facility, and support and research buildings. The single TSD unit in the 400 Area is the Maintenance and Storage Facility.

2.1.4.4 600 Area. The 600 Area covers all locations not specifically given an area designation. The TSD units within the 600 Area are primarily in support of the overall waste management activities throughout the Hanford Facility. The following TSD units are included in the 600 Area:

- 616 Nonradioactive Dangerous Waste Storage Facility

- 600 Area Purgewater Storage and Treatment Facility.

\subsection{TOPOGRAPHIC MAP [B-2]}

Drawing H-6-958 in Appendix $2 A$ provides a general overview of the Hanford Site and surrounding area. The drawing illustrates the following:

- Boundary of the Hanford Site (for area shown)

- Contours [at 20-foot (6.1-meter) intervals] sufficient to show surface water flow

- Fire control services on the Hanford Site

- Access roads, internal roads, railroads, perimeter gates, and barricades

- Longitudes and latitudes.

Prevalling wind directions across the Hanford Site are presented in Figure 2-3. Prevailing wind directions on the 200 Areas Plateau (located approximately in the center of the Hanford Site) are from the northwest in all months of the year. Secondary maxima occur for southwesterly winds.

Monthly average wind speeds are lowest during the winter months, averaging 6 to 7 miles $(9.7$ to 11.3 kilometers) per hour, and highest during the summer, averaging 9 to 10 miles ( 14.5 to 16.1 kilometers) per hour. Wind speeds that are well above average usually are associated with southwesterly winds. However, the summertime drainage winds generally are northwesterly and frequently reach 31 miles $(49.9$ kilometers) per hour. Estimates of wind extremes have been summarized by Stone et al. (1983). Information on the likelihood and frequency of strong winds and tornados in the region have been summarized in a final environmental impact statement (DOE 1987), the Hanford Meteorological Station climatological summary (Stone et al. 1983), and reports from the National Severe Storms Forecast Center. 
The relationship between the boundaries of the Hanford Site and the Hanford Facility is shown in Figures 2-1 and 2-2. A legal description of the Hanford Facility is contained in Appendix 2B.

A topographic map for TSD units for which final status is sought, showing a distance of at least 1,000 feet (305 meters) around the TSD unit, is found in the Unit-Specific Portion of this permit application. These TSD unitspecific topographic maps are often drawn at a scale of 1 centimeter equal to 20 meters $(1: 2,000)$. The contour interval $(0.5$ meter or 1.6 feet) clearly shows the pattern of surface water flow in the vicinity of each TSD unit. In addition, the following information is included:

- Map scale

- Date

- Prevailing wind direction

- A north arrow

- Surrounding land use

- Location of the unit

- Access road location

- Access control

- Groundwater monitoring wells (if applicable).

\subsection{LOCATION INFORMATION [B-3]}

This section describes the location of the Hanford Facility in relation to seismic, floodplain, and shoreline considerations.

\subsubsection{Seismic Risk Consideration [B-3a]}

The Hanford Facility is located in Zone 2B as identified in the Uniform Building Code (ICBO 1991). Seismic risk considerations for individual TSD units are addressed in the Unit-Specific Portion of this permit application.

\subsubsection{Floodplain Standard [B-3b]}

Three sources of potential flooding of the Hanford Facility are considered: (1) the Columbia River, (2) the Yakima River, and (3) storm-induced run-off in ephemeral streams draining the Hanford Facility. No perennial streams occur in the central part of the Hanford Facility.

The Federal Emergency Management Agency has not prepared floodplain maps for the Columbia River through the Hanford Site. The flow of the Columbia River is largely controlled by several upstream dams that are designed to reduce major flood flows. Based on a U.S. Army Corps of Engineers study of the flooding potential of the Columbia River that considered historic data and water storage capacity of the dams on the Columbia River (COE 1969), the U.S. Department of Energy (ERDA 1976) has estimated the probable maximum flood (Figure 2-4). The estimated probable maximum flood would have a larger

52 floodplain than either the 100- or 500-year floods. 
The 100-year floodplain for the Yakima River, as determined by the Federal Emergency Management Agency (FEMA 1980), is shown in Figure 2-5.

The only other potential source of flooding of the Hanford Facility is run-off from a large precipitation event in the Cold Creek watershed. This event could result in flooding of the ephemeral Cold Creek. Skaggs and Walters (1981) have given an estimate of the probable maximum flood using conservative values of precipitation, infiltration, surface roughness, and topographic features. The 100-year flood is less than the probable maximum flood as shown in Figure 2-6.

The location of individual TSD units with respect to the identified floodplains is addressed in the Unit-Specific Pnotion of this permit application.

2.3.2.1 Demonstration of Compliance [B-3b(1)]. Demonstration of compliance for individual TSD units, where applicable, is detailed in the Unit-Specific Portion of this permit application.

2.3.2.1.1 Flood Proofing and Flood Protection Measures [B-3b(1)(a)]. Demonstration of compliance for individual TSD units, where applicable, is detailed in the Unit-Specific Portion of this permit application.

2.3.2.1.2 Flood Plan [B-3b(1)(b)]. Demonstration of compliance for individual TSD units, where applicable, is detailed in the Unit-Specific Portion of this permit application.

2.3.2.2 Plan for Future Compliance with Floodplain Standard [B-3b(2)]. Demonstration of compliance for individual TSD units, where applicable, is detailed in the Unit-Specific Portion of this permit application.

\subsubsection{Shorel ine Standard [B-3C]}

The TSD units within the Hanford Facility are not located within regulated 'shorel ines of the state' or 'wetlands' as defined in the Shoreline Management Act of 1971. The Hanford Facility is located within the Hanford Site, which is owned by the U.S. Government and managed by the DOE-RL. The Hanford Site is not classified as natural, conservancy, rural, or residential.

\subsubsection{Sole Source Aquifer Criteria [B-3d]}

The Hanford Facility is not located over a 'sole source aquifer' as defined in Section 1424(e) of the Safe Drinking Water Act of 1974. Therefore, no demonstration of compliance is required. 
DOE/RL-91-28, Rev. 1 $05 / 28 / 93$

\subsection{TRAFFIC INFORMATION [B-4]}

The regional public highway network traversing the Hanford Site (Washington State Highways 24 and 240), nonrestricted access roadways (Route 10, and portions of Route 4S located south of the Wye Barricade), and restricted access roadways are shown in Figure 2-7.

Roadways on the Hanford Site east of the Yakima Barricade and north of the hiye Barricade, and within the 300 and 400 Areas, are restricted to authorized personnel only. Other U.S. Department of Energy roadways are subject to such restrictions or ciosure as the U.S. Department of Energy might require. Estimated traffic volumes for the 1990 timeframe, in vehicles per day, are shown in Figure 2-7. The majority of traffic is passenger vehicles used for commuting and conducting company business. Approximately 10 percent of the traffic volume is trucks, and these trucks are mainly delivery, construction, and maintenance vehicles.

\subsubsection{Hanford Site Roadways}

Figure 2-7 shows the major roads throughout the Hanford Site. These roads are classified as either primary or secondary routes. The primary routes include Routes $45,10,2 \mathrm{~N}, 3,6$, and $11 \mathrm{~A}$, as well as various avenues within each area. The primary routes are constructed of bituminous asphalt [usually 2 inches (5 centimeters) thick, but the thickness of the asphalt layer will vary with each road] with an underlying aggregate base in accordance with U.S. Department of Transportation requirements. The secondary routes are constructed of layers of an $0 i l$ and rock mixture with an underlying aggregate base. The aggregate base consists of various types and sizes of rock found onsite. Currently, no load-bearing capacities of these roads are available; however, loads as large as 140 pounds per square inch (9.8 kilograms per square centimeter) have been transported without observable damage to road surfaces. All roads meet the requirements for the American Association of State Highway and Transportation Officials HS-20-44 load rating (AASHTO 1983). An HS-20-44 loading represents a two-axle tractor [front axle loading of 8,000 pounds $(3,630$ kilograms) and rear axle loading of $32,000$ pounds $(14,500$ kilograms $)]$ plus a single-axle trailer with a 32,000 -pound $(14,500$ kilogram) axle loading.

\subsubsection{Traffic Control Signs, Signals, and Procedures}

Standard traffic control signs are used throughout the Hanford Site (e.g., hexagonal stop signs, triangular yield signs). Speed limits are posted throughout the Hanford Site, and the maximum posted speed is 55 miles (88 kilometers) per hour on major thoroughfares. Inside the various areas, posted speeds are reduced to a maximum of 35 miles (56 kilometers) per hour and held to speeds as low as 15 miles (24 kilometers) per hour. 


\subsubsection{Hanford Site Railroad System}

Some dangerous and mixed waste is transported to and/or from TSD units (e.g., Double-Shell Tank System, Low-Level Burial Grounds) in railroad cars. The general location of rail lines can be found on Drawing $\mathrm{H}-6-958$ in Appendix 2A. Typically, shipments are made during periods of low traffic activity (i.e., between 9:00 a.m. and 3:00 p.m., on weekends, or during offpeak traffic hours). All roads that cross the waste route are barricaded by the Hanford Patrol during shipments to prevent motor vehicle accidents. Based on evaluation of risk, railroad shipments are prohibited during periods of low visibility, when there are winds il excess of 15 miles (25 kilometers) per hour, and during heavy rain, snow storms, or icy conditions.

All railroad track, track beds, and related equipment are maintained to the requirements of Federal Railroad Association track safety standards for Class III track as detailed in 49 CFR 213. Class III track is sufficient for the loads and train speeds on the Hanford Site.

\subsection{PERFORMANCE STANDARDS [B-5]}

The Hanford Facility TSD units are designed to minimize the exposure of personnel to dangerous waste and hazardous substances and to prevent dangerous waste and hazardous substances from reaching the environment. In addition, measures are taken to ensure that the TSD units for which final status is sought are maintained and operated in a manner that prevents the following:

- Degradation of groundwater quality

- Degradation of air quality by open burning or other activities

- Degradation of surface water quality

- Destruction or impairment of flora or fauna

- Excessive noise

- Negative aesthetic impacts

- Unstable hillsides or soils

- Use of processes that do not treat, detoxify, recycle, reclaim, and recover waste material to the extent economically feasible

- Endangerment to the health of employees or the public.

The measures taken to prevent each of these potentially negative effects from occurring are described in the following sections. Closure performance standards are discussed in Chapter 11.0, Section 11.2. 


\subsubsection{Measures to Prevent Degradation of Groundwater Quality}

The Hanford Facility is located in an area having a semiarid climate with an average annual rainfall of about 6.3 inches (16 centimeters). Therefore, aerial recharge that could transport contamination to groundwater is 1 imited. In addition, many TSD units use double containment piping and leak detection, grading and ground cover, and/or other measures to prevent degradation of groundwater quality. Measures to be taken for individual TSD units are detailed, where applicable, in the Unit-Specific Portion of this permit application.

\subsubsection{Measures to Prevent Degradation of Air Quality by Open Burning or Other Activities}

On the Hanford Facility, open burning and other activities that might degrade air quality are curtailed to the extent practicable. In addition, the arid climate limits vegetation on the Hanford Facility. Vegetation around many TSD units is removed routinely, so that there is a low potential for accidental open burning and for the wind transport of contaminated vegetation. Measures to be taken for individual TSD units are detailed, where applicable, in the Unit-Specific Portion of this permit application.

\subsubsection{Measures to Prevent Degradation of Surface Water Quality}

The potential for degradation of surface water is extremely low. There are two natural surface water bodies on or bordering the Hanford Facility, West Lake and the Columbia River. West Lake is located southwest of Gable Mountain (Drawing H-6-958 in Appendix 2A) and is approximately 10 acres ( 4.07 hectares) in size and 3 feet ( 0.91 meter) deep. The Columbia River is located along the northern and eastern boundary of the Hanford Facility. The TSD units for which final status is sought are sufficiently removed from these surface water bodies to reduce the potential for degradation.

Because of the drainage characteristics of the native soils, rainwater generally soaks into the sandy soil rather than running on the surface. Small pools can be observed occasionally after rapid snowmelt, but the pools usually dissipate within 72 hours. Measures to be taken for individual TSD units are detailed, where applicable, in the Unit-Specific Portion of this permit application.

\subsubsection{Measures to Prevent Destruction or Impairment of Flora or Fauna Outside of the Treatment, Storage, and/or Disposal Units}

Most of the Hanford Facility beyond the bounds of the 200, 300, 400, and 1100 Areas is maintained as a natural habitat. Many TSD units and areas within the Hanford Facility are surrounded by perimeter chain link fences to prevent access by larger animals. The continued practice of removing flora from inside TSD unit boundaries discourages fauna from entering these areas in search of food. Measures to be taken for individual TSD units to prevent 
destruction or impairment of flora or fauna outside the units are detailed, where applicable, in the Unit-Specific Portion of this permit application.

\subsubsection{Measures to Prevent Excessive Noise}

The Hanford Facility is sufficiently removed from residential and offsite industrial areas (Drawing H-6-958 in Appendix 2A) to preclude excessive noise impacts. Measures to be taken for individual TSD units are detailed, where applicable, in the Unit-Specific Portion of this permit application.

\subsubsection{Measures to Prevent Negative Aesthetic Impacts}

Most of the TSD units within the Hanford Facility are located in restricted areas. These units are not visible from offsite or are visible only from a great distance. This aspect helps to eliminate any significant negative aesthetic impacts from these TSD units. Measures to be taken for individual TSD units are detailed, where applicable, in the Unit-Specific Portion of this permit application.

\subsubsection{Measures to Prevent Unstable Hillsides or Soils}

There are no naturally unstable hillsides or soils within or adjacent to existing TSD units. Compaction of the soil is used to stabilize the soil during and after any construction activities. Native vegetation often is planted to eliminate erosion potential of soils due to wind and water. Measures to be taken for individual TSD units are detailed, where applicable, in the Unit-Specific Portion of this permit application.

\subsubsection{Measures to Prevent the Use of Processes That Do Not Treat, Detoxify, Recycle, Reclaim, and Recover Waste Material to the Extent Economically Feasible}

Measures to prevent the use of processes that do not treat, detoxify, recycle, reclaim, and recover waste material to the extent economically feasible are taken into consideration in the operation of Hanford Facility TSD units. Measures to be taken for individual TSD units are detailed, where applicable, in the Unit-Specific Portion of this permit application.

\subsubsection{Measures to Prevent Endangerment to the Health of Employees or the Public Near the Hanford Facility}

Measures to prevent endangerment of the health of employees or the public near the Hanford Facility include monitoring of released effluents, monitoring of groundwater, monitoring of ambient air, and training of employees in the handling and management of dangerous waste. Measures to be taken for individual TSD units are detailed, where applicable, in the Unit-Specific Portion of this permit application. 


\subsection{BUFFER MONITORING ZONES [B-6]}

Buffer monitoring zones, where applicable, will be in accordance with the National Fire Protection Association, NFPA-30, Chapter 7, and WAC 173-303-640(9)(b). Additional information for individual TSD units can be found in the Unit-Specific Portion of this permit application.

\subsection{SPILLS AND DISCHARGES INTO THE ENVIRONMENT [B-7]}

Descriptions of the procedures, structures, and equipment used at the Hanford Facility to: (1) prevent hazards and contain spills in unloading or loading operations; (2) prevent run-off from dangerous waste handling areas to other areas or the environment, and to prevent flooding; (3) prevent contamination of water supplies; (4) mitigate effects of equipment failure and power outage; and (5) prevent undue exposure of personnel to dangerous waste are contained in the Unit-Specific Portion of this permit application.

Actions to be taken in the event of noncompliance with final status requirements that may endanger human health and the environment, including aity incidence of noncompliance resulting from release or discharge of dangerous waste that might endanger human health and the environment outside the Hanford Facility, are documented in Chapter 7.0.

\subsubsection{Notification [B-7a]}

Reporting of any noncompliance with final status requirements that might endanger human health and the environment will be to Ecology in accordance with the immediate reporting provisions of WAC 173-303-810(14)(f) and will include information on the following:

- Release of dangerous waste that might cause an endangerment to drinking water supplies or ground or surface waters

- Any information of a release or discharge of dangerous waste, a fire, or an explosion that could threaten the environment or human health outside the Hanford Facility

- Name, address, and telephone number(s) of the owner or operator

- Date, time, and type of incident

- Name and quantity of material(s) involved

- The extent of injuries if any

- An assessment of actual or potential hazards to the environment and human health outside the Hanford Facility, where this is applicable 


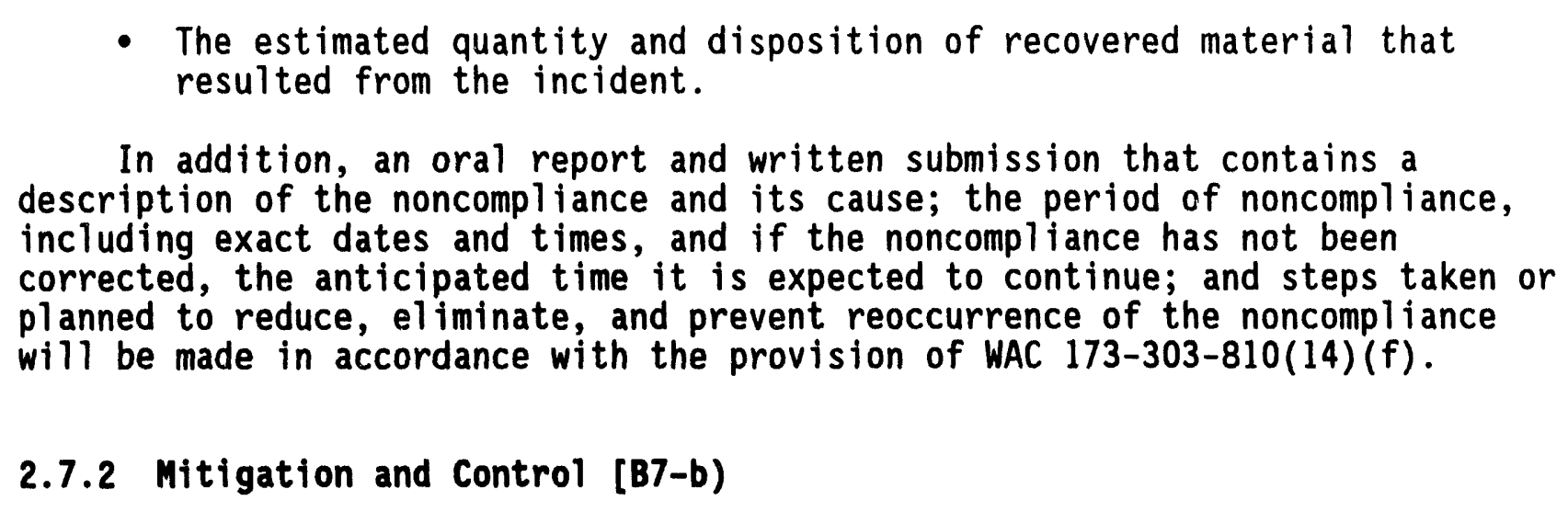

- The estimated quantity and disposition of recovered material that resulted from the incident.

In addition, an oral report and written submission that contains a description of the noncompliance and its cause; the period of noncompliance, including exact dates and times, and if the noncompliance has not been corrected, the anticipated time it is expected to continue; and steps taken or planned to reduce, eliminate, and prevent reoccurrence of the noncompliance will be made in accordance with the provision of WAC 173-303-810(14)(f).

\subsubsection{Mitigation and Control [B7-b)}

Releases or discharges of dangerous waste that endanger human health and the environment will be dispositioned in accordance with the applicable provisions of Chapter 7.0 and the applicable provisions of WAC 173-303-600.

\subsubsection{Cleanup and Management of Released Dangerous Wastes and Contaminated} Soil, Water, or Other Materials [B7-b(1) and (2)]. Provisions for dispositioning of recovered material resulting from an incident that endangers human health and the environment will be in accordance with the applicable provisions of Chapter 7.0 and the applicable provisions of WAC 173-303-600.

2.7.2.2 Restoration of Impacted Area [B7-b(3)]. Restoration of property outside the Hanford Facility that is impacted by releases or discharges of dangerous waste, fire, or explosion will be accomplished in accordance with the applicable provisions of WAC 173-303-600.

\subsection{MANIFEST SYSTEM [B-8]}

The Hanford Facility handles dangerous waste from onsite sources and mixed waste from both onsite and offsite sources. This section briefiy discusses the system that is in place to track waste shipments.

\subsubsection{Onsite Waste Shipments}

The Hanford Site has one EPA/State identification number as required by WAC 173-303-060, and all TSD units within the Hanford Facility are part of a single dangerous waste facility. Therefore, onsite shipments of dangerous or mixed waste are not subject to the manifesting requirements specified in WAC 173-303-370 and -180. However, all onsite waste shipments are conducted in a manner to ensure protection of human health and the environment. Four onsite waste tracking systems are voluntarily used for transporting waste on the Hanford Facility. The following four systems are used to track the transfer of waste: 
DOE/RL-91-28, Rev. I

$05 / 28 / 93$

- Liquid mixed waste via underground pipelines

- Liquid mixed waste via railroad tank car or tank truck or via barrels transported by truck

- Containerized mixed waste (e.g., rags, failed equipment, contaminated soil) via trucks and railroad cars

- Containerized nonradioactive dangerous waste via truck before being shipped offsite for treatment, storage, and/or disposal at a TSD facility.

Onsite waste tracking records for individual TSD units are maintained on file and can be located by contacting RCRA Compliance Support (Chapter 12.0).

\subsubsection{Offsite Waste Shipments}

Offsite shipments of dangerous waste to and from the Hanford Facility are subject to the manifesting requirements specified in WAC 173-303-370 and -180 , respectively. The EPA Uniform Hazardous Waste Manifest is used for transporting dangerous waste from the Hanford Facility to an offsite TSD facility. Mixed waste could be shipped offsite in the future (e.g., to the Waste Isolation Pilot Plant in New Mexico or to a national repository when these sites become operational). Offsite waste transfer information for individual TSD units can be found in the Unit-Specific Portion of this permit application. Offsite waste tracking records for individual TSD units are maintained on file and can be located by contacting RCRA Compliance Support (Chapter 12.0).

\subsubsection{Receipt of Offsite Waste}

The Hanford Facility receives dangerous and mixed waste from offsite (including foreign) sources. Such waste is subject to the manifesting requirements specified in WAC 173-303-370 and to the reporting requirements of WAC 173-390(1). Notification for foreign waste receipt is made in accordance with WAC 173-303-290. Notification of subsequent shipments of the same waste from the same foreign source in the same calendar year is not required.

Offsite waste receipt information specific to individual TSD units can be found in the Unit-Specific Portion of this permit application. Offsite waste receipt records for individual TSD units are maintained on file and can be located by contacting RCRA Compliance Support (Chapter 12.0).

\subsection{QUALITY ASSURANCE AND QUALITY CONTROL PROGRAM FOR THE HANFORD FACILITY}

The quality assurance and quality control information for individual TSD units can be found in the Unit-Specific Portion of this permit application. The information is integrated, as appropriate, with the quality 
assurance and control program in the Tri-Party Agreement, as specified in 2 Article $X X X$, and Sections 6.5 and 7.8 of the Tri-Party Agreement Action Plan.

Specific operational activities are governed by procedures that are 5 maintained by each TSD unit. Copies of these procedures are retained on file 6 in the unit operating record and can be located for inspection by contacting 7 RCRA Compliance Support (Chapter 12.0). In accordance with WAC 173-303-806, a 8 description of procedures pertinent to dangerous waste management activities 9 is included in the Unit-Specific Portion of this permit application.

of relevance to Hanford Facility groundwater monitoring and closure activities are the environmental investigation instructions (EIIs) (WHC 1988). Applicable EIIs are briefly described in the Unit-Specific Portion of this permit application. Current copies of the EIIs also are maintained on file and can be located by contacting RCRA Compliance Support (Chapter 12.0). In accordance with the Tri-Party Agreement, EIIs are designated as 'secondary documents' and will be reviewed by the regulators in accordance with

18 Section 9.2.3 of the Tri-Party Agreement Action Plan. 
DOE/RL-91-28, Rev. 1

$05 / 28 / 93$

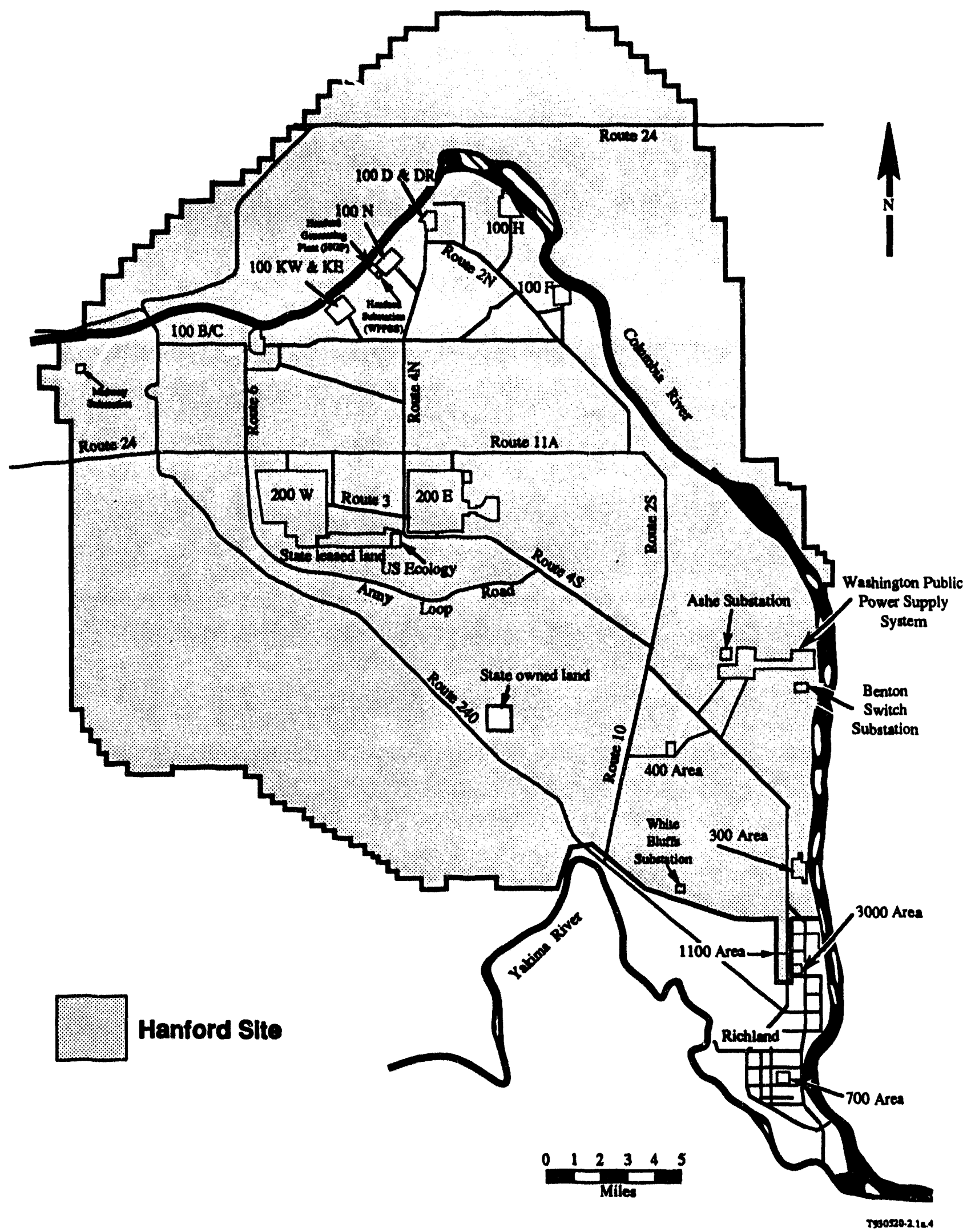

Figure 2-1. Hanford Site Map. 
DOE/RL-91-28, Rev. 1

$05 / 28 / 93$

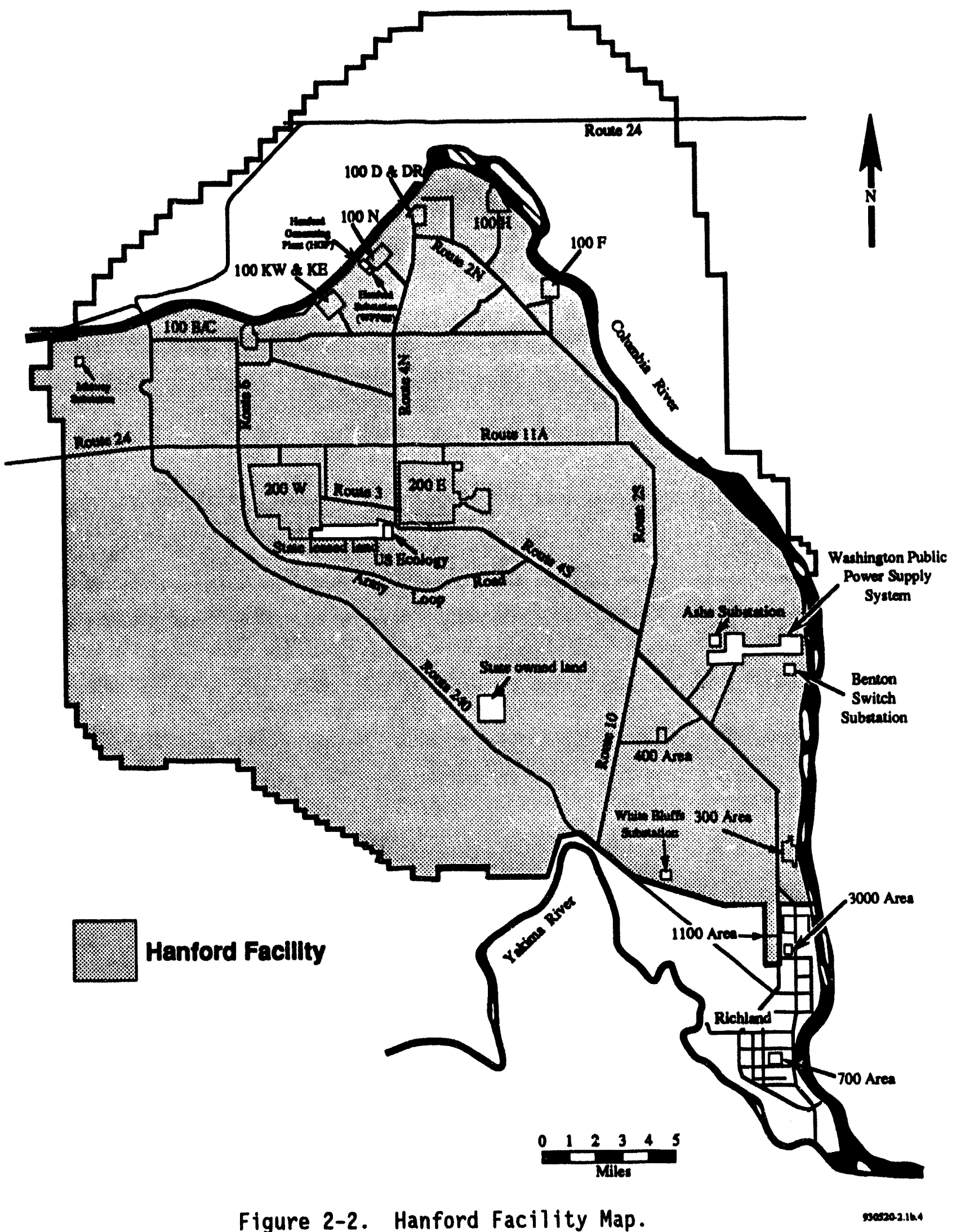

Figure 2-2. Hanford Facility Map. 


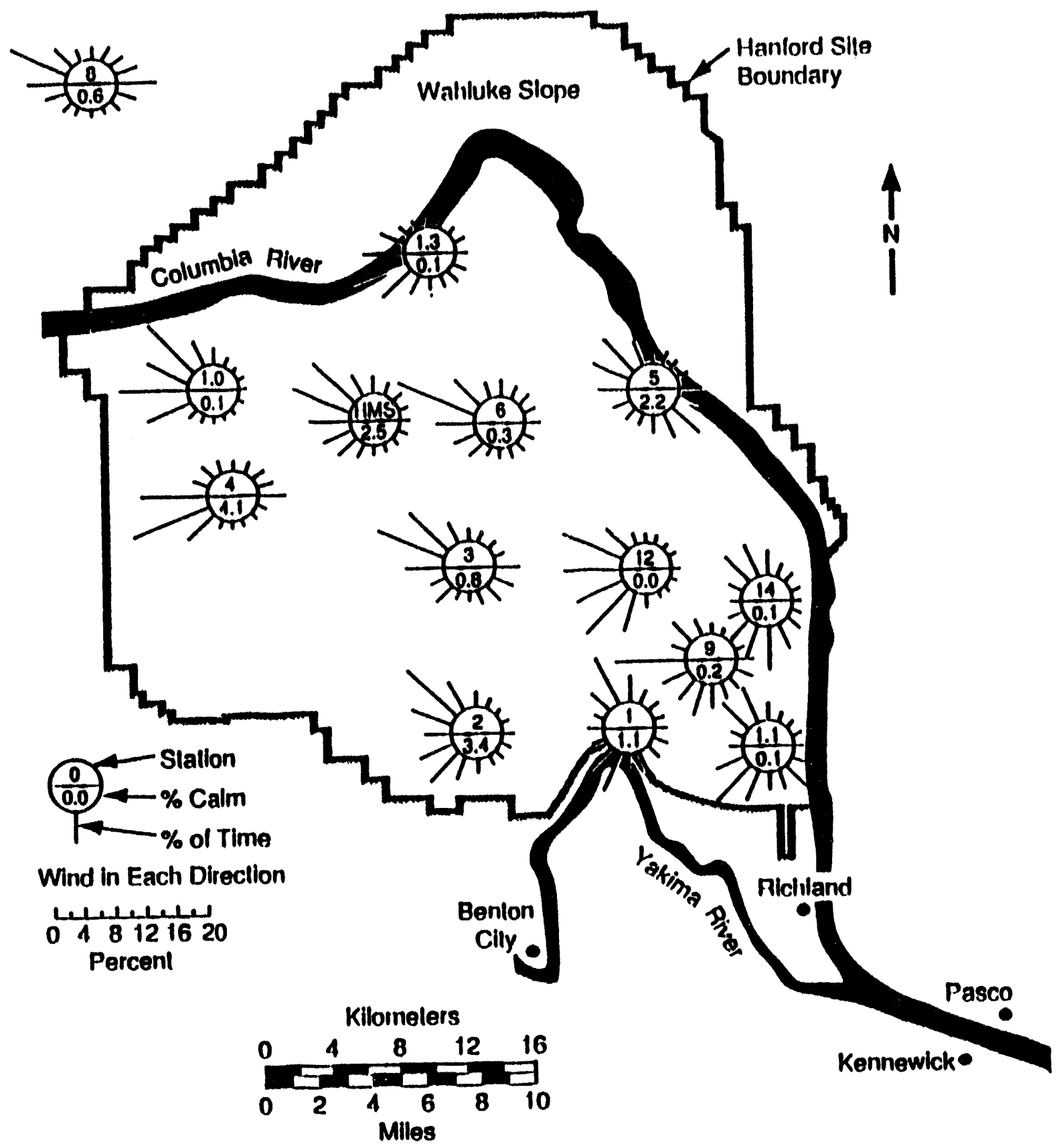

HMS = Haniord Meleorological Slalion

39108105.6

Figure 2-3. Prevailing Wind Direction for the Hanford Site. 


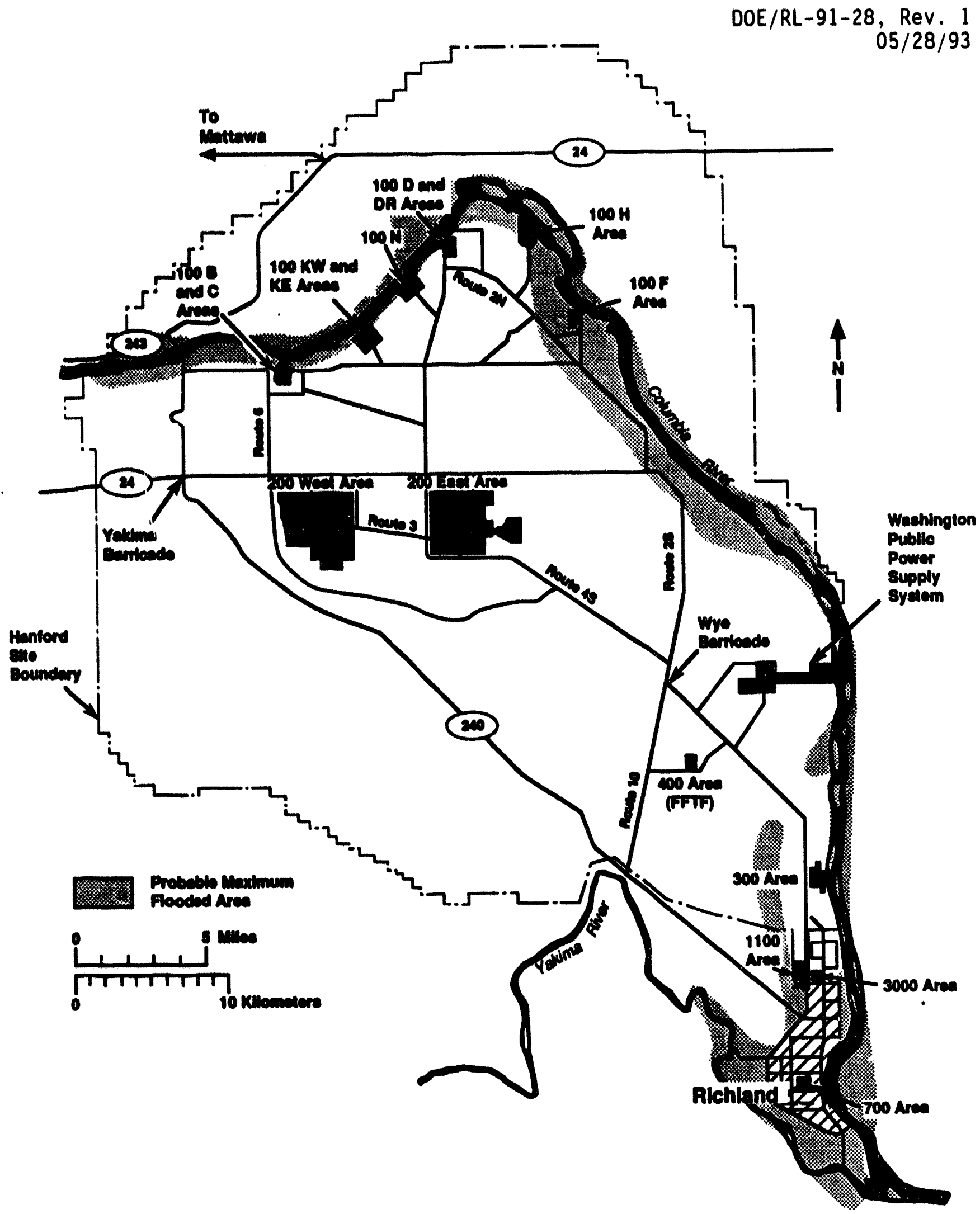

Tr30520.R1a

Figure 2-4. Columbia River Floodplain (probable maximum flood). 

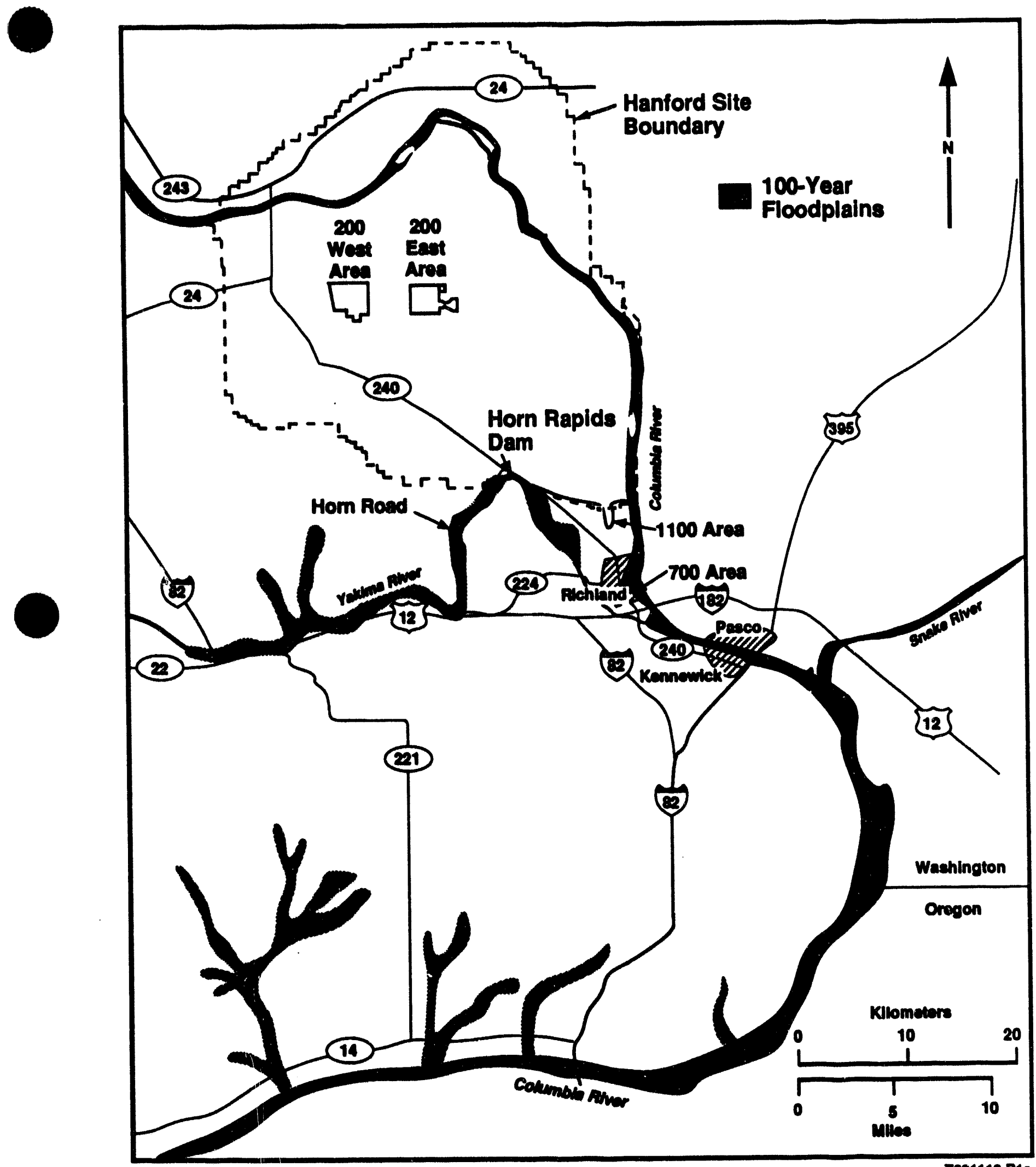

Te21112.R1e

Figure 2-5. Yakima River Floodplain. 


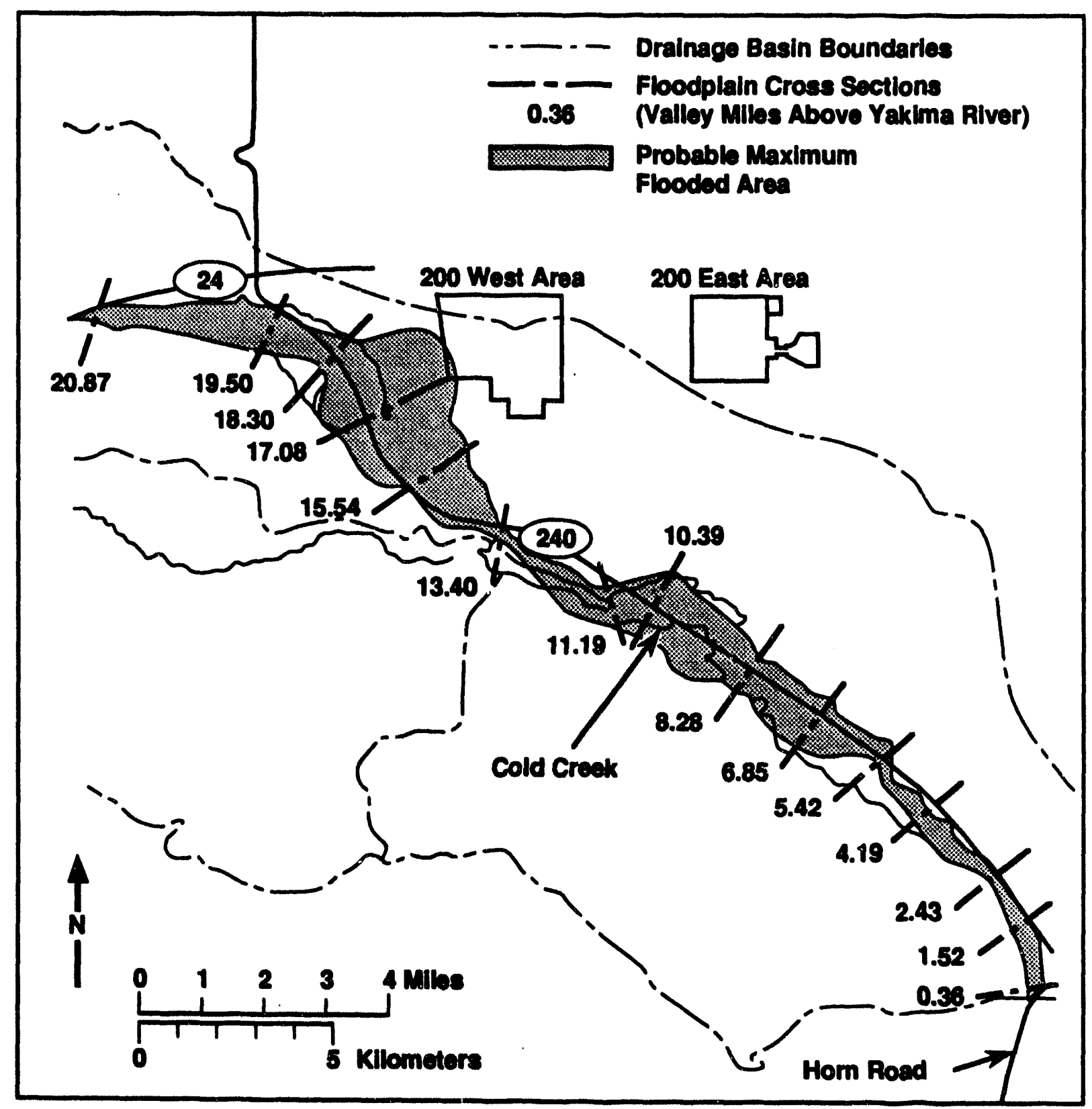

TP21112.R1a

Figure 2-6. Cold Creek Watershed Floodplain (probable maximum flood). 
DOE/RL-91-28, Rev. 1 $05 / 28 / 93$

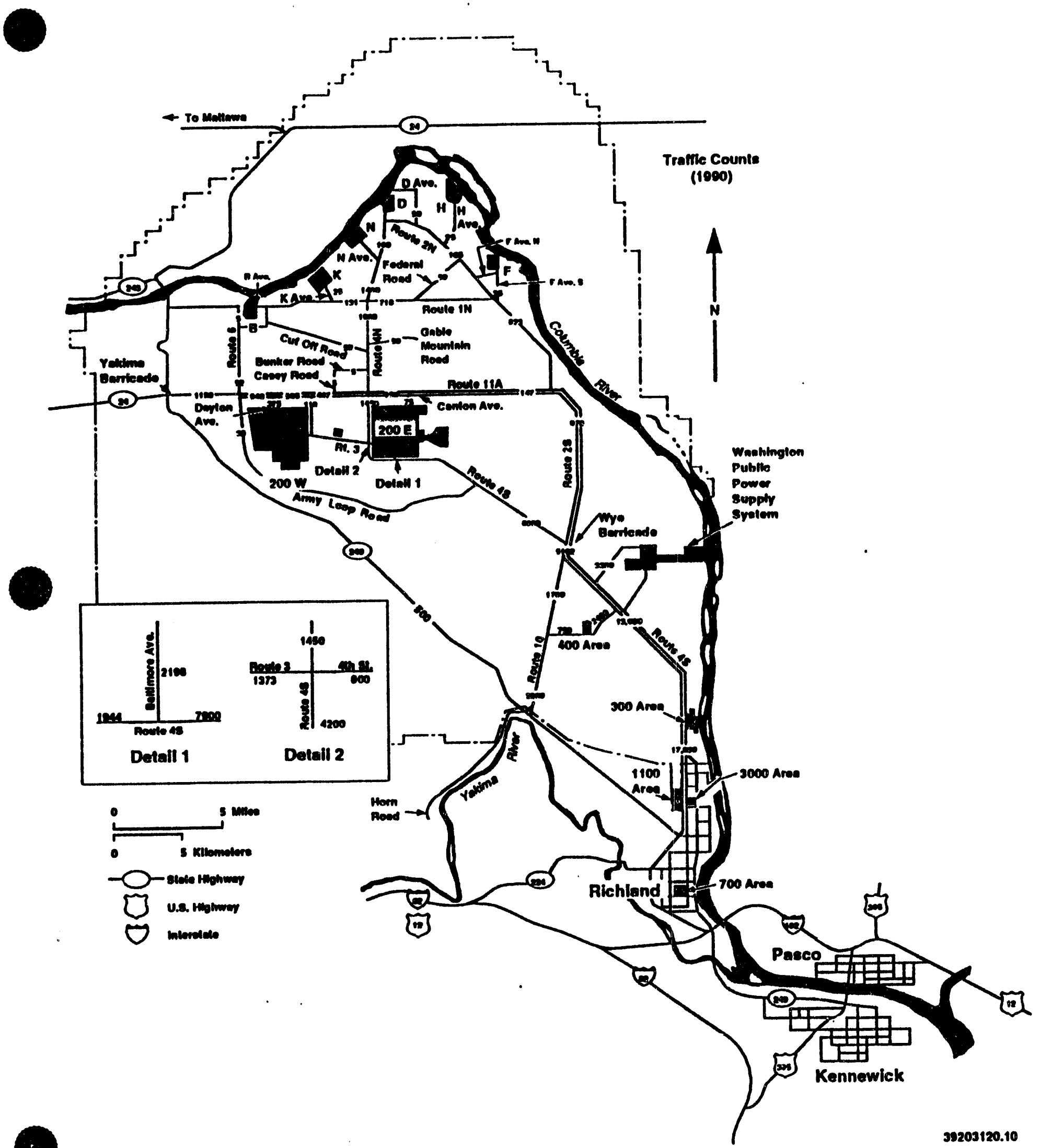

Figure 2-7. Estimated Traffic Volumes (vehicles per day). 
Table 2-1. Hanford Facility Treatnent, Storage, and/or Disposal Units.

\begin{tabular}{lll}
\hline \multicolumn{1}{c}{ Unit } & Area & Class \\
\hline Double-ShelT Tank System & $200 \mathrm{EW}$ & TS \\
242-A Evaporator & $200 \mathrm{E}$ & $\mathrm{T}$ \\
Hanford Waste Vitrification Plant & $200 \mathrm{E}$ & TS \\
Grout Treatment Facility & $200 \mathrm{E}$ & TSD \\
204-AR Waste Unloading Station & $200 \mathrm{E}$ & $\mathrm{T}$ \\
Central Waste Complex & $200 \mathrm{~W}$ & $\mathrm{TS}$ \\
Waste Receiving and Processing & $200 \mathrm{~W}$ & $\mathrm{~T}$ \\
Low-Level Burial Grounds & $200 \mathrm{EW}$ & $\mathrm{D}$ \\
Liquid Effluent Retention Facility & $200 \mathrm{E}$ & $\mathrm{S}$ \\
200 Area Effluent Treatment Facility & $200 \mathrm{E}$ & $\mathrm{T}$ \\
T Plant Complex & $200 \mathrm{~W}$ & $\mathrm{~T}$ \\
B Plant & $200 \mathrm{E}$ & $\mathrm{TS}$ \\
24I-Z Treatment and Storage Tanks & $200 \mathrm{~W}$ & $\mathrm{TS}$ \\
222-S Laboratory Complex & $200 \mathrm{~W}$ & $\mathrm{TS}$ \\
224-T Transuranic Waste Storage and Assay Facility & $200 \mathrm{~W}$ & $\mathrm{~S}$ \\
PUREX Storage Tunnels & $200 \mathrm{E}$ & $\mathrm{S}$ \\
325/3100 Hazardous Waste Treatment Unit & 300 & $\mathrm{TS}$ \\
Biological Treatment Test Facilities & 300 & $\mathrm{~T}$ \\
Physical/Chemical Treatment Test Facilities & 300 & $\mathrm{TS}$ \\
Thermal Trtatment Test Facilities & 300 & $\mathrm{~T}$ \\
305-B Storage Unit & 300 & $\mathrm{~S}$ \\
Maintenance and Storage Facility & 400 & $\mathrm{~T}$ \\
616 Nonradioactive Dangerous Waste Storage Facility & 600 & $\mathrm{~S}$ \\
600 Area Purgewater Storage and Treatment Facility & 600 & TS \\
\hline
\end{tabular}

Unit--Name of TSD unit for which final status is sought (as of March 15, 1993) as part of the Hanford Facility (EPA/State Identification Number WA7890008967).

Area--The area of the Hanford Facility in which the unit is located: $200 \mathrm{E}$-- 200 East Area 300 -- 300 Area $200 \mathrm{~W}$-- 200 West Area 400 -- 400 Area 200EW -- Parts of a unit are located 600 -- 600 Area. in both the 200 East and the 200 West Areas

Class--Waste unit operational classification T--Treatment S--Storage D--Disposal 
DOE/RL-91-28, Rev. 1 $05 / 28 / 93$

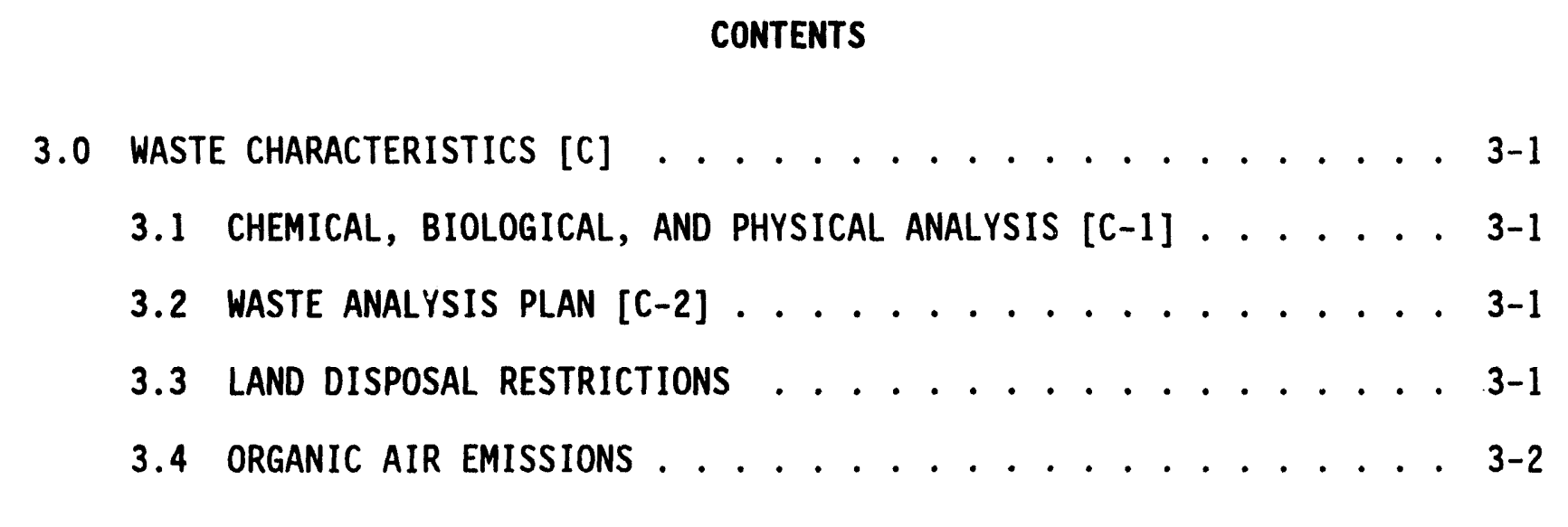
13 
DOE/RL-91-28, Rev. 1

$05 / 28 / 93$

This page intentionally left blank. 
DOE/RL-91-28, Rev. 1

$05 / 28 / 93$

\subsection{WASTE CHARACTERISTICS [C]}

This chapter provides general information on the chemical, biological, and physical characteristics of the waste treated, stored, and/or disposed of on the Hanford Facility. General information provided in this chapter covers the following areas:

- Chemical, biological, and physical analysis

- Land disposal restrictions.

Detailed information on the characteristics of the waste treated, stored, and/or disposed of at individual TSD units is contained in the Unit-Specific Portion of this permit application.

\subsection{CHEMICAL, BIOLOGICAL, AND PHYSICAL ANALYSIS [C-1]}

The Hanford Facility treats, stores, and/or disposes of dangerous and/or mixed waste designated as: (1) characteristic dangerous waste; (2) toxic, carcinogenic, and persistent (by WAC 173-303 criteria); and (3) 1isted (because the waste contains small amounts of spent solvents and discarded pure chemical products). The waste form ranges from liquid to hard crystalline material (e.g., salt cake stored in tank farms), as well as contaminated equipment, paper, rags, etc. A general overview of waste characteristics and process information for each TSD unit for which final status is sought (as of March 15, 1993) is contained in Chapter 4.0.

Specific information on the characteristics and volume of waste that could be handled by each TSD unit is contained in the Hanford Facility Dangerous Waste Part A Permit Application (DOE-RL 1988b). Part A permit application information is based primarily on process information with supplemental information provided by waste sampling and analysis programs.

\subsection{WASTE ANALYSIS PLAN [C-2]}

The WAC 173-303-300 requires that knowledge about a dangerous waste be confirmed by a facility owner/operator before this waste is stored, treated, and/or disposed of. The purpose for the acquisition of such knowledge is to ensure that this dangerous waste is managed properiy. Waste analysis plans required by WAC 173-303-300(5) are addressed in the Unit-Specific Portion of this permit application. For TSD units thit receive waste from offsite sources, the waste analysis plan includes measures for confirming that each dangerous waste received matches the identity of the waste specified on the accompanying manifest or shipping paper in accordance with WAC $173-303-300(5)(g)$.

\subsection{LAND DISPOSAL RESTRICTIONS}

Dangerous waste and the dangerous waste portion of mixed waste on the Hanford Facility is subject to land disposal restrictions (40 CFR 268). Under 
the regulations, some waste is prohibited from land disposal. Other waste can be 7 and disposed of, if the waste can meet certain treatment standards specified in 40 CFR 268, Subpart D. The best demonstrated available technologies also are specified in the regulations for some waste in lieu of meeting a specific concentration requirement. Provisions in the Tri-Party Agreement (Ecology et al. 1992) allow for storage of land disposal restricted waste beyond the 1-year period allowed in 40 CFR 268.50. The TSD units will follow the provisions of their waste analysis plans (Section 3.2) to determine which, if any, land disposal restrictions apply to their waste.

Should it become necessary to seek an exemption from a disposal prohibition pursuant to 40 CFR 268.6, an extension to the effective date of any land disposal restriction pursuant to 40 CFR 268.5, a variance from a treatment standard pursuant to 40 CFR 268.44 , or an exemption pursuant to WAC 173-303-140(6), the records documenting the quantities and date each waste was placed under such exemption, extension, or variance will be maintained as required by 40 CFR $264.73(10)$.

\subsection{ORGANIC AIR EMISSIONS}

The organic air emissions released from Hanford Facility process vents are regulated under RCRA (40 CFR 264 Subpart AA and 40 CFR 265 Subpart AA). These regulations apply to process vents associated with specific separation processes, identified in 40 CFR 264.1030(b) and 40 CFR 265.1030(b), that are used to manage hazardous waste with organic concentrations of at least 10 parts per million by weight. Threshold limits that require emission controls apply to the summation of all applicable emission sources for the entire Hanford Facility. To determine whether the threshold limits are exceeded, thereby requiring emission controls, the applicable processes were identified first for each TSD unit. The TSD units that had the potential processes identified in the regulations, at the time of the evaluation, are as follows:

- B Plant

- PUREX Plant

- 242-A Evaporator

- Double-Shell Tank System

- 222-S Laboratory Complex

- Maintenance and Storage Facility.

These TSD units were evaluated for purposes of addressing the Subpart $A A$ regulations. A conservative summation of the organic air emissions resulted in a release rate of 0.1 pound $(0.045 \mathrm{kilogram})$ per hour or 0.438 ton (398 kilograms) per year. This release is well below the threshold of 3 pounds (6.6 kilograms) per hour or 3.1 tons $(2,818$ kilograms) per year. The amount of organic emissions might change as TSD units are brought on 1 ine (e.g., Hanford Waste Vitrification Plant) or are deactivated (e.g., PUREX Plant). The organic air emissions summation will be reevaluated periodically as conditions warrant. 


\section{CONTENTS}

4.0 PROCESS INFORMATION $[D] \ldots \ldots$. . . . . . . . . . . .

4.1 OVERVIEW ........................ 4-1

4.2200 AREAS .................. . . 4-3

4.2.1 Treatment Units ............. 4-3

4.2.1.1 242-A Evaporator......... 4-3

4.2.1.2 Hanford Waste Vitrification Plant . . . . 4-3

4.2.1.3 Grout Treatment Facility ......... 4-4

4.2.1.4 204-AR Waste Unloading Station . . . . . . 4-4

4.2.1.5 Waste Receiving and Processing ....... 4-4

4.2.1.6 200 Area Effluent Treatment Facility.... 4-5

4.2.1.7 T Plant Complex ............. 4-5

4.2.1.8 B Plant .............. 4-6

4.2.1.9 241-Z Treatment and Storage Tanks ..... 4-6

4.2.1.10 222-S Laboratory Complex . . . . . . . . . 4-6

4.2.2 Storage Units ............. . . . . . . . .

4.2.2.1 Double-She11 Tank System . . . . . . . . 4-7

4.2.2.2 Central Waste Complex ......... . 4-7

4.2.2.3 Liquid Effluent Retention Facility. . . . . 4-7

4.2.2.4 224-T Transuranic Waste Storage and Assay Facility. .......... 4-8

4.2.2.5 PUREX Storage Tunneis ........... 4-8

4.2 .3 Disposal Units .............. 4-. . . .

4.3300 AREA .................... . . . . . . . . . .

4.3.1 Treatment Units ............ . . 4-9

4.3.1.1 325/3100 Hazardous Waste Treatment Unit ... 4-9

4.3.1.2 Biological Treatment Test Facilities . . . . 4-10

4.3.1.3 Physical/Chemical Treatment Test

Facilities....... 4-10

4.3.1.4 Thermal Treatment Test Facilities ..... 4-10

4.3.2 Storage Units ................ 4-11

4.4400 AREA ........................ . . . . . . . .

4.5600 AREA ................... . . . . . . . . .

4.5.1 616 Nonradioactive Dangerous Waste Storage

Facility ............ . . . 4-12

4.5.2 600 Area Purgewater Storage and Treatment

Facility .............. 4-12

4.6 DESIGN AND OPERATIONAL INFORMATION ......... . . . . . . . .

4.6.1 Transmittal of Design Information to Regulatory

Agencies .............. 4- . . . . . . . . .

4.6.2 Utilization of Aperture Cards . . . . . . . . 4-14

4.6.3 Replacement or Upgrading With Functionaliy

Equivalent Components ......... 4-14

4.6.4 Professional Engineer Certification . . . . . . 4-14 
DOE/RL-91-28, Rev. 1 $05 / 28 / 93$

1
2
3
4
5

This page intentionally left blank. 
DOE/RL-9l-28, Rev. 1

$05 / 28 / 93$

\subsection{PROCESS INFORMATION [D]}

This chapter presents information on the various processes that are used in the management of dangerous waste and mixed waste on the Hanford Facility. Dangerous waste and/or mixed waste TSD units on the Hanford Facility for which final status is sought (as of March 15, 1993) include, but are not limited to, tank systems, surface impoundments, container storage areas, waste piles, landfills, and miscellaneous units. Also included in this chapter is a discussion of the processes used to control design and operational information, and the method for transmitting design and operational changes to the regulators. In addition, a discussion of certification is included, as it pertains to supporting certain RCRA and dangerous waste permitting activities.

For each TSD unit for which final status is sought (as of March 15, 1993), the following information is provided: the classification of the TSD unit (e.g., surface impoundment, container storage unit, etc.); the type of waste processed at the TSD unit (dangerous and/or mixed waste); and a brief description of the waste management process or processes conducted at the TSD unit. Information presented in this chapter has been compiled from existing documents and is current as of March 15, 1993. The following documents have been used as the primary sources of information: Hanford Site Dangerous Waste Part A Permit Application (DOE-RL 1988b), Draft Environmental Restoration and Waste Management Fiscal Year 1993 Site-Specific Plan for the Richland Field Office (DOE-RL 1993), and the Tri-Party Agreement.

Activities conducted within the Hanford Facility that only involve the management of radioactive waste are not regulated under the RCRA or the WAC 173-303 regulations and, therefore, are not addressed in this chapter. References to such activities are included for informational purposes only.

\subsection{OVERVIEW}

The Hanford Facility generates dangerous and mixed waste, and treats, stores, and disposes of dangerous and mixed waste that is generated onsite. Mixed waste that is generated offsite also is managed within certain TSD units on the Hanford Facility.

The waste managed on the Hanford Facility includes low-activity and highactivity waste, low activity and high-activity mixed waste, transuranic waste, transuranic mixed waste, and nonradioactive dangerous waste. As discussed in Chapter 2.0, Section 2.1.3, most of the waste management activities fall into two major programmatic areas: Tank Waste Remediation System and Solid/Liquid Waste Remediation.

The scope of the Tank Waste Remediation System includes managing all programs, projects, and activities for receiving, safely storing, maintaining, treating, and packaging tank waste for onsite or offsite disposal. The Tank Waste Remediation System currently is conducting rebaselining activities that could cause approaches to waste management to change as program planning 
1 proceeds and input is received from stakeholders (e.g., regulators and the 2 public) (WHC 1993b).

The scope of the Solid/Liquid Waste Remediation Program includes (1) storing solid waste safely until a disposal decision is reached, (2) providing handling and treatment capabilities for management of solid waste and preparation for final disposal, and (3) eliminating releases of untreated liquid effluents and treating and disposing of 1 iquid waste according to applicable federal and state laws and regulations. The following overview of waste management within the Hanford Facility summarizes the roles currently planned for key TSD units.

The Double-Shell Tank System stores and treats radioactive and mixed waste generated on the Hanford Site before final treatment and disposal. The Double-Shell Tank System storage space is maximized through the use of the 242-A Evaporator. This treatment unit concentrates the double-shell tank waste by removal of water and volatile/semivolatile organics through evaporation. The concentrated slurry is returned to the Double-Shell Tank System and the process condensate is transferred for storage to the Liquid Effluent Retention Facility. Eventually the process condensate will be transferred from the 242-A Evaporator to the 200 Area Effluent Treatment Facility, once this unit comes online.

The Hanford Waste Vitrification Plant will treat the high-activity portion of waste stored in the Double-Shell Tank System by converting the waste into glass, with ultimate disposal of the vitrified waste in a national repository. The Grout Treatment Facility will process low-activity doubleshell tank waste by combining this waste with grout-forming solids and, if necessary, chemical additives. The grouted waste will be disposed of in nearsurface vaults.

Solid waste management activities are supported by five key TSD units. The Central Waste Complex treats and stores radioactive and/or mixed waste. The Waste Receiving and Processing unit will treat mixed waste, low-level waste, and transuranic waste. The treated transuranic waste eventually will be transported for disposal to the Waste Isolation Pilot Plant in New Mexico (when this plant becomes operational) or to another approved waste disposal site. The Low-Level Burial Grounds disposes of solid low-level radioactive waste and mixed waste. The 616 Nonradioactive Dangerous Waste Storage Facility and the 305-B Storage Unit store dangerous waste before shipment offsite for treatment, storage, and/or disposal. Small-quantities of mixed waste also are stored at the 305-B Storage Unit before being transported to the Central Waste Complex.

The Hanford Facility TSD units for which final status is sought (as of March 15, 1993) are located in the 200,300, 400, and 600 Areas (Appendix 2A). These units are described briefly, by area, in the remainder of this section. More detailed process information for TSD units is presented in the Hanford Facility Dangerous Waste Part A Permit Application, Form 3s. These Form 3s contain an identification of specific dangerous waste codes, process design capacities, and estimated quantities of waste handled annualiy. 
A11 TSD units to be discussed, except where noted, will be operated under interim status until final status conditions for these TSD units are incorporated into the Hanford Facility Permit.

\subsection{AREAS}

The 200 Areas encompass the chemical separations plants for the reprocessing of nuclear materials as well as radioactive waste storage and disposal. These reprocessing plants generated various dangerous, radioactive, and mixed waste that was discharged to the soil column or stored in underground storage tanks (referred to as tank farms). The original mission for the plants in the 200 Areas was in support of nuclear weapons development and production. The mission of the Hanford Site currently is focusing on waste management and environmental restoration and remediation activities.

Currently, final status is sought (as of March 15, 1993) for 16 treatment, storage, and/or disposal units located in the 200 Areas.

\subsubsection{Treatment Units}

Treatment units located in the 200 Areas for which final status is sought (as of March 15, 1993) are discussed in the following sections.

4.2.1.1 242-A Evaporator. The 242-A Evaporator is a miscellaneous treatment unit located in the 200 East Area. The 242-A Evaporator consists of process vessels and support systems for heating, evaporating, and condensing waste stored in the Double-Shell Tank System. The 242-A Evaporator receives a mixed waste stream from the Double-She11 Tank System that contains organic and inorganic constituents and radionuclides. Treatment of the waste at the 242-A Evaporator results in two mixed waste streams. One mixed waste stream (slurry) contains the majority of the radionuclides and inorganic constituents (an extremely hazardous mixed waste) and one mixed waste streain (process condensate) contains greatly reduced concentrations of radionuclides and volatile and semivolatile organic materials (a dangerous waste containing de minimus quantities of radionuclides). The slurry is routed back to the Double-Shel1 Tank System for storage pending further treatment. The process condensate will be discharged to the Liquid Effluent Retention Facility where the process condensate will be stored until the 200 Area Effluent Treatment System becomes operational.

The 242-A Evaporator will be operated under interim status until incorporated into the Hanford Facility Permit.

4.2.1.2 Hanford Waste Vitrification Plant. The Hanford Waste Vitrification Plant is a treatment, storage, and miscellaneous unit. The Hanford Waste Vitrification Plant will be located in the 200 East Area and will treat and store the high-activity and transuranic fraction of waste contained within the Double-She 11 Tank System. This mixed waste, received from a pretreatment unit, will be treated in a series of tanks and a melter, classified as a miscellaneous unit. Treatment will include concentration by evaporation, 
1 adjustment with chemicals and glass forming materials, and immobilization in

2 borosilicate glass (vitrification). The melter and the waste treatment tanks

3 will be capable of storing dangerous waste under offnormal conditions.

Secondary liquid mixed waste generated by the Hanford Waste Vitrification Plant will be collected and treated in a series of tanks. Treatment will include neutralization, filtration, sorption, and evaporation. The highactivity fraction from the treatment process will be recycled. The remainder will be transferred to the Double-Shell Tank System.

Secondary nonradioactive dangerous waste generated from leaks, spills, and/or overflows from chemical storage, makeup, and feed tanks will be collected, treated in a series of tanks, and stored at the Hanford Waste Vitrification Plant. Treatment will include neutralization, concentration by solar evaporation, and decomposition of dangerous constituents during storage.

The vitrified waste will be cast into stainless steel canisters and stored at the Hanford Waste Vitrification Plant until the canisters are shipped to a national repository.

The Hanford Waste Vitrification Plant will be constructed and operated under interim status until incorporated into the Hanford Facility Permit.

4.2.1.3 Grout Treatment Facility. The Grout Treatment Facility, located in the 200 East Area, is categorized as a surface impoundment, miscellaneous treatment unit, and a land disposal unit. The Grout Treatment Facility receives selected mixed waste from the Double-Shell Tank System. The waste is mixed with grout forming solids and, if necessary, chemical liquid additives in an in-line mixer. This process (miscellaneous treatment) forms a cementious slurry, which is pumped to lined concrete disposal vaults. The disposal vaults are managed as surface impoundments when the grout slurry is liquid and closed as landfills after the grout slurry has hardened.

The Grout Treatment Facility will be operated under interim status until incorporated into the Hanford Facility Permit.

4.2.1.4 204-AR Waste Unloading Station. The 204-AR Waste Unloading Station is a miscellaneous treatment unit that is used for the unloading and treatment of liquid mixed waste received from railroad tank cars. The waste is generated from decontamination and regeneration operations in the 100 Areas; from reprocessing operations at the 200 Areas; from recovery, fuels fabrication, and laboratory operations in the 300 Area; and from decontamination operations in the 400 Area. During unloading operations, the $\mathrm{pH}$ of the waste is adjusted chemically in-line during pump out to meet the corrosion protection requirements of the Double-Shell Tank System.

The 204-AR Waste Unloading Station will be operated under interim status until incorporated into the Hanford Facility Permit.

4.2.1.5 Waste Receiving and Processing. The Waste Receiving and Processing unit will treat mixed waste, low-level waste, and transuranic waste. This TSD unit will have the capability to change the physical form of the 
radioactive and/or mixed waste through compaction (volume reduction), repackaging, stabilization, solidification of liquids, neutralization, etc. The treated transuranic waste eventually will be transported for disposal at the Waste Isolation Pilot Plant in New Mexico (when this plant becomes operational) or to another transuranic waste disposal site.

The Waste Receiving and Processing unit will be operated under interim status until incorporated into the Hanford Facility Permit.

\subsubsection{200 Area Effluent Treatment Facility. The 200 Area Effluent}

Treatment Facility is a tank treatment unit that will be located in the 200 East Area. This TSD unit will be operated to treat process condensate from the 242-A Evaporator. The treatment process is expected to include filtration, $\mathrm{pH}$ adjustments, ultraviolet light oxidation, reverse osmosis, and ion exchange. Treated effluent will be collected in tanks, sampled to verify that treatment standards have been met, and discharged to the soil column, pending approval of a delisting petition by the EPA and issuance of a State Waste Discharge Permit by Ecology.

The 200 Area Effluent Treatment Facility will be constructed and operated under interim status until incorporated into the Hanford Facility Permit.

4.2.1.7 T P1ant Complex. The T Plant Complex is located in the 200 West Area. The $T$ Plant Complex consists of two structures, the 221-T Building $(221-T)$ and the 2706-T Building $(2706-T)$. The 221-T building is used for tank treatment of mixed waste before transfer to the Double-She11 Tank System. The liquid mixed waste from decontamination activities in the 221-T and 2706-T is collected and stored in tank 15-1 (located in 221-T). This liquid mixed waste can be transferred by railroad car to the 204-AR Waste Unloading Station to be treated before transfer to the Double-Shell Tank System. The liquid mixed waste also can be transferred from tank 15-1 by underground pipelines to the Double-Shell Tank System. In this case, the liquid mixed waste is treated in tank 15-1 to a pH greater than 12.0, before transfer, to make the waste more amenable for storage.

A Notice of Intent for Expansion Under Interim Status was initiated with Ecology in December of 1992 to address decontamination activities, tank storage needs, container storage and treatment capacity, and containment building capabilities of the T Plant Complex. The storage and treatment of dry and liquid mixed waste in various sized containers will occur on the canyon deck and in various cells within the 221-T Building. The storage buildings located outside the 2706-T Building also are used to store and treat containerized mixed and/or dangerous waste. Container storage capability at the T Plant Complex is required because of the need to complete laboratory analysis and characterization of mixed and/or dangerous waste samples before transferring mixed waste containers to the Central Waste Complex or dangerous waste containers to the 616 Nonradioactive Dangerous Waste Storage Facility. The treatment capability is needed in the event that it is necessary to treat the contents of some containers (e.g., addition of adsorbents to existing containers) before cransfer. The containment building capability is required to allow the storage of solid mixed waste on the 221-T canyon deck and in various cells. 


\subsubsection{241-Z Treatment and Storage Tanks. The 241-Z Treatment and Storage} Tanks is a tank treatment and storage unit located in the 241- $Z$ Building in the 200 West Area. Mixed waste generated at the Plutonium Finishing Plant (234-5Z) is transferred into the 241-Z Treatment and Storage Tanks. In che treatment tank, chemicals are added to adjust the $\mathrm{pH}$ of the waste to meet the corrosion protection requirements of the Double-Shel1 Tank System and to ensure aluminum compounds remain solubilized and provide the appropriate percentage of stable solids. Following treatment, the waste is pumped to a collection tank and transferred to the Double-Sheil Tank System for storage.

The 241-Z Treatment and Storage Tanks will be operated under interim status until incorporated into the Hanford Facility Permit.

\subsubsection{222-S Laboratory Complex. The 222-S Laboratory Complex is a} container storage and tank storage and treatment unit located in the 200 West Area. The 222-S Laboratory Complex provides analytical support services for the Hanford Site and includes tanks for treatment and storage of dangerous and mixed waste generated from analytical operations. The treatment and storage tanks associated with the 222-S Laboratory Complex consist of the 219-S Waste Handling Facility. The 219-S Waste Handling Facility consists of a primary treatment/storage tank, a backup storage tank, and a third storage tank. Mixed waste generated by the 222-S Laboratory flows by gravity to the 219-S Waste Handling Facility tank(s). In the 219-S Waste Handling Facility treatment tank, the $\mathrm{pH}$ of the waste is adjusted to meet the corrosion protection requirements of the Double-Shell Tank System. Following treatment, the waste is pumped to the Double-Shell Tank System for Storage. The

52 Dangerous and Mixed Waste Storage Area is a concrete area located on the north 
side of the 222-S Laboratory that contains six metal storage structures. The two structures on the east end of the storage area are used for the storage of containers containing dangerous and/or mixed waste (1abpacks). The other four structures store nonregulated materials.

The 222-S Laboratory Complex will be operated under interim status until incorporated into the Hanford Facility Permit.

\subsubsection{Storage Units}

Storage units located in the 200 Areas for which final status is sought (as of March 15, 1993) are discussed in the following sections.

4.2.2.1 Double-Shell Tank System. The Double-Shell Tank System is a tank treatment and storage unit located in the 200 East and West Areas. The Double-She 11 Tank System is used to treat and store mixed waste generated by Hanford Site operations and to support waste management and environmental restoration and remediation work. The Double-She11 Tank System includes 28 one-million gallon tanks, four smaller tanks in concrete vaults, and ancillary equipment such as diversion boxes and waste transfer pipelines. The tanks provide long-term storage for mixed waste generated at several locations on the Hanford Facility. Waste is treated by evaporation and by the addition of chemicals to control corrosion. The waste eventually will be retrieved, treated as necessary, and disposed of. Expansion of storage capacities may be required to support the overall Hanford waste management and restoration and remediation mission.

The Double-Shell Tank System will be operated under interim status until incorporated into the Hanford Facility Permit.

4.2.2.2 Central Waste Complex. The Central Waste Complex is located in the 200 West Area. This treatment and storage unit consists of multiple storage structures (e.g., storage modules, buildings, and a storage pad) for radioactive and/or mixed waste. The Central Waste Complex provides the capacity to store both onsite waste and waste received from offsite. A phased construction schedule will be used to accommodate any changes in the radioactive and/or mixed waste production rate.

The Central Waste Complex will be operated and expanded under interim status until incorporated into the Hanford Facility Permit.

\subsubsection{Liquid Effluent Retention Facility. The Liquid Effluent Retention} Facility, located in the 200 East Area, is categorized as a surface impoundment and miscellaneous storage unit. The Liquid Effluent Retention Facility will be used to provide interim storage of mixed waste effluent (process condensate) received from the 242-A Evaporator. The mixed waste will be stored until the 200 Area Effluent Treatment Facility is available. The Liquid Effluent Retention Facility is a retention basin consisting of three cells (surface impoundments). Each cell of the unit is constructed with two liners, a leachate collection system between the liners, and a floating cover. 52 
DOE/RL-91-28, Rev. 1

$05 / 28 / 93$

The Liquid Effluent Retention Facility will be constructed and operated under interim status until incorporated into the Hanford Facility Permit.

4.2.2.4 224-T Transuranic Waste Storage and Assay Facility. The 224-T Transuranic Waste Storage and Assay Facility is located southeast of $T$ Plant in the 200 West Area of the Hanford Facility. The 224-T Transuranic Waste Storage and Assay Facility provides a centralized unit for storage of transuranic mixed waste and low-level mixed waste from various Hanford Facility operations and from other U.S. Department of Energy and U.S. Department of Defense facilities. The transuranic mixed waste eventually will be transported for disposal to the Waste Isolation Pilot Plant in New Mexico (when this plant becomes operational) or to another approved waste disposal site. The 224-T Transuranic Waste Storage and Assay Facility also will store retrieved containers of transuranic mixed waste from the Low-Level Burial Grounds. The Low-Level Burial Grounds transuranic mixed waste will be stored for characterization and reprocessing at the Waste Receiving and Processing unit. Assays of the waste at the 224-T Transuranic Waste Storage and Assay Facility consist of nondestructive testing to ensure that the waste meets waste acceptance criteria for the unit and for offsite disposal at the Waste Isolation Pilot Plant or another approved waste disposal site.

The 224-T Transuranic Waste Storage and Assay Facility will be operated under interim status until incorporated irito the Hanford Facility Permit.

4.2.2.5 PUREX Storage Tunnels. The PUREX Storage Tunnels are miscellaneous storage units located in the 200 East Area next to the PUREX Plant. The PUREX Storage Tunnels include two underground railroad storage tunnels used for the long-term storage of process equipment removed from the PUREX PIant. Since being placed into service, various types of equipment containing mixed waste have been stored in the tunnels on railroad cars. The major components of the PUREX Storage Tunnels include the water-fillable doors, the storage area, and the ventilation system. Tunnel number 1 provides storage space for eight railroad cars. Between June 1960 and January 1965, al1 eight railroad car positions were filled and the tunnel subsequently sealed. Tunnel Number 2 is considerably longer than Tunnel Number 1 and provides storage space for 40 railroad cars. The first railroad car was placed in Tunnel Number 2 in December 1967.

The PUREX Tunnels supports the PUREX Plant. In December 1992, the U.S. Department of Enerijy-Headquarters determined that the PUREX PIant would no longer operate and directed that the PUREX PIant be deactivated. Tentative plans call for the preparation of a combined PUREX Plant and Storage Tunnels closure plan. If this is the case, PUREX Tunnels documentation (document number DOE/RL-90-24) will be removed from the Unit-Specific Portion of this permit application. Based on this approach, final status will not be sought for the PUREX Storage Tunnels. 
DOE/RL-91-28, Rev. 1

$05 / 28 / 93$

23

51

52

\subsubsection{Disposal Units}

Except for the Grout Treatment Facility, the only disposal unit located in the 200 Areas for which final status is sought (as of March 15, 1993) is the Low-Level Burial Grounds.

The Low-Level Burial Grounds TSD unit is categorized as a landfill. The Low-Level Burial Grounds TSD unit is divided into eight burial grounds. Each burial ground consists of a number of trenches. Six burial grounds are located in the 200 West Area and two burial grounds are located in the 200 East Area. The Low-Level Burial Grounds TSD unit currently accepts for disposal low-level waste and disposes of mixed waste according to its characteristics. The mixed waste is generated by several different operations, both on and off the Hanford Facility. The waste is packaged in steel, concrete, or wooden containers and placed in the burial trenches. Since 1987, most mixed waste, other than submarine reactor compartments, is being stored at the Central Waste Complex until a lined disposal trench is constructed within the Low-Level Burial Grounds.

The Low-Level Burial Grounds will be operated under interim status until incorporated into the Hanford Facility Permit.

\subsection{AREA}

The 300 Area historically was used for the fabrication of the 100 Area reactor fuels and for the main research and development activities for the Hanford Site. Fuels fabrication activities ceased when $\mathrm{N}$ Reactor was placed in standby. Current activities include research and development supporting the waste management and environmental restoration and remediation mission, including the development of new technologies for the treatment and disposal of the waste accumulated throughout the life of the Hanford Site.

Currently (as of March 15, 1993), final status is sought for five TSD units located in the 300 Area. The TSD units include both treatment and storage units.

\subsubsection{Treatment Units}

Treatment units located in the 300 Areas for which final status is sought (as of March 15, 1993) are discussed in the following sections.

\subsubsection{325/3100 Hazardous Waste Treatment Unit. The 325/3100 Hazardous} Waste Treatment Unit, categorized as a miscellaneous treatment unit, currently is located in rooms 520 and 528 of the 325 Building. At present, the 3100 portion of the unit is not active. Current plans are for the construction of a new building, or retrofitting of an existing building, in the 300 Area.

The 325/3100 Hazardous Waste Treatment Unit is used to treat small quantities of diverse chemicals and mixed waste generated from ongoing research and development activities. The 325/3100 Hazardous Waste Treatment 
1

Unit treats mixed waste by grouting and other processes and also serves as a research and development area to test and evaluate the effectiveness of thermal, physical, chemical, and biological treatment technologies.

The 325/3100 Hazardous Waste Treatment Unit will be operated under interim status until incorporated into the Hanford Facility Permit.

\subsubsection{Biological Treatment Test Facilities. The Biological Treatment Test} Facilities TSD unit is categorized as a miscellaneous treatment unit. The Biological Treatment Test Facilities unit is used to perform research, development, and testing of biological waste treatment technologies capable of treating dangerous waste. These technologies can treat various chemical constituents, such as organics, nitrates, chromium, and cyanide waste constituents in soil; effluents; and groundwater through the use of microorganisms (naturally present organisms or organisms that are environmentally enhanced). Technologies are tested in selected laboratories in the 324, 325, and 331 Buildings; however, the technologies are being developed for future uses in other units and at dangerous waste remedial action locations.

The Biological Treatment Test Facilities TSD unit will be operated under interim status until incorporated into the Hanford Facility Permit. An evaluation currently is underway to determine if an alternate permitting approach, such as preparation of a research, development, and demonstration permit application, might be more appropriate.

\subsubsection{Physical/Chemical Treatment Test Facilities. The Physical and} Chemical Treatment Test Facilities TSD unit is categorized as a miscellaneous treatment unit. The Physical and Chemical Treatment Test Facilities TSD unit is used to perform research, development, and testing of physical and chemical waste treatment technologies for the treatment of mixed waste. These technologies are tested in hot cell complexes in the 324 and 325 Buildings and in selected laboratories in the 324 Building. The technologies are being developed for future uses in other units and at dangerous waste remedial action locations.

The Physical and Chemical Treatment Test Facilities Unit will be operated under interim status until incorporated into the Hanford Facility Permit. An evaluation currently is underway to determine if an alternate permitting approach, such as preparation of a research, development, and demonstration permit application, might be more appropriate.

\subsubsection{Thermal Treatment Test Facilities. The Thermal Treatment Test} Facilities TSD unit is categorized as a miscellaneous treatment unit. The Thermal Treatment Test Facilities TSD unit is used to perform research, development, and testing of waste treatment technologies capable of treating mixed waste. These technologies are tested in the high bay and hot cell complex of the 324 Building, in the in situ vitrification test site west of the 300 Area, the 116-8-6-1 Crib, and in other selected laboratories in the 324,325 , and 331 Buildings. The technologies are being developed for future uses in other units and at dangerous waste remedial action locations. 
DOE/RL-91-28, Rev. 1

$05 / 28 / 93$

The Thermal Treatment Test Facilities Unit will be operated under interim status until incorporated into the Hanford Facility Permit. An evaluation currentiy is underway to determine if an alternate permitting approach, such as preparation of a research, development, and demonstration permit application, might be more appropriate.

\subsubsection{Storage Units}

Currently (as of March 15, 1993), the only storage unit located in the

\subsection{AREA}

The 400 Area was developed for the experimentation of breeder reactor technologies, development of isotopes for medical uses, and development and testing of equipment and materials under high radiation fields. The Fast flux Test Facility is the main reactor used in this experimentation. Currently (as of March 15, 1993), the only TSD unit in the 400 Area is the Maintenance and Storage Facility.

The Maintenance and Storage Facility is categorized as a tank treatment unit for washing residual sodium from Fast Flux Test Facility spent nonfuel components before their storage and disposal. The process consists of placing sodium contaminated material in a tank and reacting surface sodium contamination with water. To date, the Maintenance and Storage Facility systems never have been operated for any dangerous waste management activities. A recent U.S. Department of Energy-Headquarters directive to place the Fast Flux rest Facility into a standby condition makes the need for the regulated sodium removal process at the Maintenance and Storage Facility uncertain.

The Maintenance and Storage Facility unit will remain under interim status until the Part A permit application, form 3 , is withdrawn or until this TSD unit is incorporated into the Hanford Facility Permit. 


\subsection{AREA}

The 600 Area includes everything within the Hanford Site boundary that is not within any other specific area. Currently, two TSD units are located within the 600 Area. These units include a storage unit and a treatment and storage unit.

\subsubsection{Nonradioactive Dangerous Waste Storage Facility}

The 616 Nonradioactive Dangerous Waste Storage Facility, located between the 200 East and 200 West Areas, is categorized as a container storage unit. The 616 Nonradioactive Dangerous Waste Storage Facility provides a centralized unit to receive, store, and prepare for offsite shipment nonradioactive dangerous waste. Before receipt of dangerous waste at the 616 Nonradioactive Dangerous Waste Storage Facility, the generating unit characterizes the waste, assigns waste codes according to WAC 173-303, and packages the waste according to U.S. Department of Transportation regulations for hazardous materials. The waste is shipped to the 616 Nonradioactive Dangerous Waste Storage Facility by truck. Once a waste shipment is accepted from the transporter, 616 Nonradioactive Dangerous Waste Storage Facility personnel select an appropriate storage cell for each container, depending on the dangerous waste designation. Approximately 18 times per year, depending on the rate of waste accumulation, containers are remanifested, inspected for offsite shipment, and transported to an offsite TSD facility.

The 616 Nonradioactive Dangerous Waste Storage unit will be operated under interim status until this unit is incorporated into the Hanford Facility Permit.

\subsubsection{Area Purgewater Storage and Treatment Facility}

The 600 Area Purgewater Storage and Treatment Facility, located north of the 216-B-3 Pond System, is categorized as a miscellaneous storage and treatment unit. The 600 Area Purgewater Storage and Treatment Facility is used for interim storage and treatment of purgewater generated from groundwater monitoring wells located throughout the Hanford Facility. The purgewater is generated when a groundwater monitoring well is developed or groundwater samples are obtained. The purgewater from a groundwater monitoring well is transported by tank truck and pumped directly into the 600 Area Purgewater Storage and Treatment Facility, consisting of six aboveground structures. Treatment of the purgewater by evaporation is carried out in these six structures.

The designation of purgewater as a dangerous waste is presently being evaluated. The 600 Area Purgewater Storage and Treatment Facility unit will be operated under interim status until the Part A permit application, Form 3 , is withdrawn or until this unit is incorporated into the Hanford Facility Permit. 


\subsection{DESIGN AND OPERATIONAL INFORMATION}

This section presents a discussion of the processes used to control design and operational information, and the method for transmitting design and operational changes to the regulators. In addition, a discussion of certification is included, as it pertains to supporting certain RCRA and dangerous waste permitting activities.

\subsubsection{Transmittal of Design Information to Regulatory Agencies}

Design of TSD units on the Hanford Facility is controlled in accordance with an established engineering control system. Standard engineering practices ensure that uniform methods are in place to control tasks such as design review, configuration control, change control, specification preparation, and review and approval requirements. These practices are used on all engineering, development, and project work on the Hanford Facility, which result in a documented design or deliverable hardware end item.

Development of, and changes to, design specifications and drawings related to TSD units on the Hanford Facility are carried out in accordance with the engineering practices of the contractor responsible for the activity. Although there is some variation among contractors, no work affecting design (excluding emergency response activities that will be conducted in accordance with contingency plans) is allowed to be performed at a TSD unit until an approved design drawing or appropriate engineering design directive has been issued. This process ensures that components and materials selected meet system requirements while providing a means for configuration control.

The contents of WAC 173-303-830 require that design changes, at a minimum, be submitted as Class 1 permit modifications. This requires that permit holders submit specific information regarding the design change to the regulatory agencies within 7 days after the change is put into effect. The magnitude of the work on the Hanford Facility that involves modifications to existing approved designs is substantial, and the following approach will be used to address the modification process. Requirements specified in WAC 173-303-830 will be followed for design changes categorized as Class 2 or Class 3 permit modifications and for design changes categorized as Class 1 permit modifications requiring regulatory agency approval before implementation. Other Class 1 changes will be submitted annually in accordance with Chapter 1.0, Section 1.5, of the General Information Portion of this permit application. Classification of permit modifications will be as established in Appendix I of WAC 173-303-830.

On an ongoing basis, a tabulation of design changes (for those TSD units incorporated into the Hanford Facility Permit) can be located through RCRA Compliance Support (Chapter 12.0). 
41

\subsubsection{Utilization of Aperture Cards}

Additions to the Unit-Specific Portion of this permit application are prepared according to the requirements prescribed in WAC 173-303-806. These requirements specify inclusion of certain design information, including design drawings as well as other engineering data.

Design drawings included as part of unit-specific documentation will be provided in an 11-inch by 17-inch format. Drawings provided in this format, for the most part, will exhibit a sufficient degree of legibility to support document review. In selected cases, it might be necessary to enlarge certain portions of drawings to enhance legibility. To support this need, drawings included as part of unit-specific documentation also will be provided in an aperture card format.

\subsubsection{Replacement or Upgrading With Functionally Equivalent Components}

All maintenance on the Hanford Facility is controlled and performed in accordance with an established work control system. The work control system ensures that the proper documentation is prepared for the activity, and also provides a means to track work from initiation to completion.

The contents of WAC 173-303-830, Appendix I, identify equipment replacement or upgrading with functionally equivalent components (e.g., pipes, valves, pumps, conveyors, controls) as a Class 1 modification to a permit. This requires that permit holders submit specific information regarding the use of functionally equivalent compunents to the regulatory agencies within 7 days after the change is put into effect. The magnitude of the work on the Hanford Facility that involves the use of functionally equivalent components is substantial, and the following approach will be used to address the modification process. On an ongoing basis, a tabulation of functional equivalency information (i.e., a listing of equivalent equipment substitutions for those TSD units incorporated into the Hanford Facility Permit) can be located through RCRA Compliance Support (Chapter 12.0). Class 1 changes relating to functionally equivalent components (for those TSD units incorporated into the Hanford Facility Permit) will be submitted annually in accordance with Chapter 1.0, Section 1.5, of the General Information Portion of this permit application.

\subsubsection{Professional Engineer Certification}

Certifications in accordance with WAC $173-303-810(13)(a)$ by an independent registered professional engineer/registered professional engineer are required to support certain RCRA and dangerous waste permitting activities on the Hanford Facility (e.g., tank integrity assessments, closures, etc.). Such certification, where required, will be conducted using a U.S. Department of Energy contractor or subcontractor. Employees of the U.S. Department of Energy will not be used to make the certifications. 


\section{CONTENTS}

5.0 GROUNDWATER MONITORING $[$ E] . . . . . . . . . . . 5-1

5.1 EXEMPTION FROM GROUNDWATER MONITORING REQUIREMENTS [E-1] . . . 5-3

5.2 INTERIM STATUS PERIOD GROUNDWATER MONITORING DATA [E-2] . . . 5-3

5.2.1 Interim Status Groundwater Monitoring Approach . . . . . 5-3

5.2.2 Investigative Methods . . . . . . . . . . . . 5-5

5.2.2.1 Existing Hanford Site Hydrogeologic

Information.......... 5-5

5.2.2.2 General Well Design .......... . 5-5

5.2.2.3 Well Locations . . . . . . . . . . . . . 5-6

5.2.2.4 Downgradient and Upgradient Interim Status Wells ............ . . 5-6

5.2.2.5 General Hydrogeologic Investigative Techniques ............ 5-6

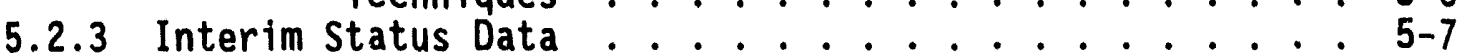

5.2.3.1 Sampling and Analysis Plan . . . . . . 5-8

5.2.3.2 Analytical Data............ . 5-9

5.3 AQUIFER IDENTIFICATION [E-3] . . . . . . . . . . . 5-10

5.3.1 Physiographic and Geomorphic Setting . . . . . . . . 5-11

5.3.2 Climate and Meteorology ............. 5-11

5.3.2.1 Wind .................. . 5-11

5.3.2.2 Temperature and Humidity ........ 5-12

5.3.2.3 Precipitation ............. 5-12

5.3.3 Regional Geology .. . . . . . . . . . . . 5-12

5.3.4 Regional and Hanford Site Hydrology . . . . . . . . 5-14

5.3.4.1 Surface Hydrology . . . . . . . . . . . 5-14

5.3.4.2 Groundwater .............. . 5-14

5.3.5 Uppermost Aquifer ................ 5-15

5.3.6 Uppermost Confined Aquifer ............ 5-16

5.3.7 Groundwater Travel Times . . . . . . . . . . . . 5-17

5.3.7.1 Vadose Zone .. . . . . . . . . . . . . 5-17

5.3.7.2 Saturated Zone ............. 5-17

5.4 CONTAMINANT PLUME DESCRIPTION [E-4] . . . . . . . . . 5-18

5.4.1 Radionuclide Contamination . . . . . . . . . . . . . 5-18

5.4.2 Nonradioactive Contamination .. . . . . . . . . 5-18

5.5 DETECTION MONITORING PROGRAM [E-5] . . . . . . . . 5-19

5.5.1 Monitored Indicator Parameters, Waste

Constituents, Reaction Products [E-5a] . . . . . . . 5-19

5.5.1.1 Dangerous Waste Characterization

$[E-5 a(1)] . . . . . . . .5-20$

5.5.1.2 Behavior of Constituents $[\mathrm{E}-5 \mathrm{a}(2)]$. . . . . 5-20

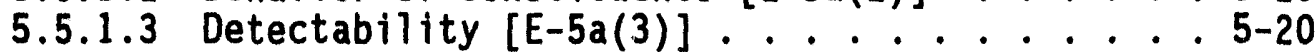

5.5. $i$ Groundwater Monitoring Program [E-5b] . . . . . . . 5-20

5.5.2.1 Description of Wells [E-5b(1)] . . . . . . 5-21

5.5.2.2 Equipment Decontamination $[E-5 b(2)] . . . .5-23$ 


\section{CONTENTS (cont)}

5.5.3 Background Values [E-5c] . . . . . . . . . . . . . 5-23

5.5.4 Sampling, Analys is, and Statistical Procedures

[E-5d] . . . . . . . . . . . . . . .

5.5.4.1 Sample Collection [E-5d(1)] ....... 5-24

5.5.4.2 Sample Preservation and Shipment

$[E-5 d(2)] \ldots \ldots 5-25$

5.5.4.3 Analytical Procedures $[E-5 d(3)] \ldots . . .5-26$

5.5.4.4 Chain of Custody [E-5d(4)] . . . . . 5-26

5.5.4.5 Additional Requirements for Compliance

Point Monitoring [E-5d(5)] . . . . 5-26

5.5.4.6 Annual Determination $[\mathrm{E}-5 \mathrm{~d}(6)] \ldots$. . . 5-27

5.5.4.7 Statistical Determination for Detection

Monitoring Program [E-5d(7)] . . . . . 5-28

5.6 COMPLIANCE MONITORING PROGRAM [E-6] . . . . . . . . . 5-29

5.6.1 Waste Description [E-6a] . . . . . . . 5-29

5.6.2 Characterization of Contaminated Groundwater [E-6b] . . 5-29

5.6.3 Dangerous Constituents to be Monitored [E-6c] . . . 5-29

5.6 .4 Concentration Limits [E-6d] ......... 5-30

5.6.5 Groundwater Monitoring System [E-6f] ....... 5-30

5.6.5.1 Description of Wells [E-6f(1)] . . . . 5-30

5.6.5.2 Representative Samples [E-6f(2)] .... 5-30

5.6.5.3 Location of Background Monitoring Wells

that Are Not Upgradient $[E-6 f(3)] \ldots$. . 5-30

5.6.6 Background Values [E-6g] . . . . . . . . . 5-30

5.6.7 Sampling, Analysis, and Statistical Procedures

$[E-6 h] \ldots \ldots \ldots$ 5-31

5.6.7.1 Sample Collection $[E-6 h(1)-(4)] \ldots$ 5-31

5.6.7.2 Additional Requirements for Compliance

Point Monitoring $[\mathrm{E}-6 \mathrm{~h}(5)] \ldots$ 5-31

5.6.7.3 Annual Determination of Hydraulic

Gradient $[E-6 h(6)] \ldots$ 5-31

5.6.7.4 Statistical Determination for Compliance

Monitoring Program $[E-6 h(7)] \ldots$. . . . . 5-31

5.7 CORRECTIVE ACTION PROGRAM $[E-7] \ldots \ldots \ldots$. . . . . . . .

\section{FIGURES}

5-1. Generalized Configuration for a Detection Monitoring

Groundwater Well System . ............. . F5-1

5-2. Flow Chart for Selection of Appropriate Statistical

Method Used for Data Interpretation . . . . . . . . . . . . . F5-2

5-3. Location of Bounding Structures of the Pasco Basin ....... . F5-3 


\section{FIGURES (cont)}

2

3

4

5

6

7

8

9

10

11

12

5-4. Divisions of the Columbia Intermontane Province and Adjacent Snake River Plains Province . . . . . . . . . . . F5-4

5-5. Generalized Stratigraphic Column of Formations

at the Hanford Site ...... . . . . . . . . . . . . . . F5-5

5-6. Generalized Geologic Cross Section Through the Hanford Site . . . F5-6

5-7. Water Table Map of the Hanford Site (June 1979) . . . . . . . . . F5-7

5-8. Potentiometric Surface of the Rattlesnake Ridge Aquifer

Beneath the Hanford Site . . . . . . . . . . . . . . F5-8

5-9. Distribution of Tritium on the Hanford Site, 1989........ . F5-9 


\section{DOE/RL-91-28, Rev. 1 $05 / 28 / 93$}

This page intentionally left blank. 
DOE/RL-91-28, Rev. 1

$05 / 28 / 93$

\subsection{GROUNDWATER MONITORING [E]}

This chapter describes the groundwater monitoring activities for Hanford Facility TSD units for which final status is sought. These activities are structured to provide groundwater monitoring systems for individual TSD units that are operated as a dangerous waste surface impoundment, waste pile, land treatment unit, or landfili. These activities also are structured for TSD units that will be closed with waste in place and thus be subject to postclosure monitoring requirements. The groundwater monitoring activities al so support Milestone M-24-00 contained in the Tri-Party Agreement Action Plan.

A description of the groundwater monitoring programs for individual TSD units is provided in the Unit-Specific Portion of this permit application. These unit-specific groundwater monitoring programs are designed to comply with Ecology regulations. These regulations are for TSD units operating under both interim status (WAC 173-303-400) and final status (WAC 173-303-645 and WAC 173-303-806). The following is a generalized discussion of the RCRA groundwater monitoring requirements for a TSO unit. This discussion provides background information relevant to subsequent, more specific groundwater monitoring discussions. In these discussions, the term 'RCRA' refers to both federal and state groundwater monitoring regulations, as appropriate.

The RCRA is implemented under two groundwater monitoring programs: interim status and final status monitoring. A TSD unit operating under interim status must have implemented a monitoring program to determine the impact of the TSD unit on groundwater quality in the uppermost aquifer beneath the TSD unit. The interim status program can take the form of either detection monitoring or assessment monitoring. At a minimum, a detection monitoring system must include one upgradient and three downgradient groundwater monitoring wells. A generalized configuration for such a system is shown in Figure 5-1. Currently (as of March 15, 1993), only interim status monitoring is being conducted as no TSD unit has yet been incorporated into the Hanford Facility Permit.

Before the installation of a detection monitoring system, a groundwater monitoring plan must be developed and followed. This plan details well locations, procedures, and techniques for well installation; sample collection, preservation, and transportation; and sample analysis. Chain-ofcustody cont ol must be developed and followed. Additionally, data quality objectives related to precision, accuracy, representativeness, completeness, and comparability [(PARCC parameters) EPA 1987] requirements are specified [e.g., in a site-specific groundwater monitoring plan and a quality assurance project plan (QAPjP)]. Also specified are methods to be used to interpret groundwater monitoring data.

The detection monitoring system is used to establish background groundwater quality through quarterly sampling and analysis of several water quality parameters (as specified in 40 CFR 265.92) for 1 year. After the first year, sampling and analysis must be conducted annually for the parameters related to groundwater quality, and semiannually for the indicator 
1

50

51

parameters related to groundwater contamination [e.g., pH, specific conductance, total organic carbon (TOC), and total organic halogen (TOX)].

If a statistically significant increase in the groundwater concentration of an indicator parameter (or pH decrease) is confirmed in the downgradient wells (Figure 5-1) of the monitoring system, the regulatory agency is notified and a groundwater quality assessment monitoring program developed. The objective of assessment monitoring is to determine if dangerous waste constituents have entered the groundwater and, if so, the concentration, rate, and extent of migration of the constituents. This determination is achieved through quarterly sampling and could require the installation of additional wells or sampling of additional existing wells. Monitoring must continue at the TSD unit through the postclosure care period.

For the TSD units for which final status is sought, there might be a three-stage groundwater monitoring program that involves detection, compliance, and corrective action, as warranted (EPA 1989b). A final status detection monitoring system must include both background (generally upgradient) and compliance (generally downgradient) wells (Figure 5-1). Wells installed to support interim status may be used as final status monitoring wells. A groundwater monitoring plan, similar to the plan described for interim status monitoring, is developed to address each final status monitoring stage. Also specified in each plan are methods to be used to conduct and interpret groundwater monitoring data. The choice of an appropriate statistical method depends on the monitoring stage and the nature of the data. A flow chart that guides the selection of the appropriate method to be used for data interpretation is presented in Figure 5-2.

In a final status detection monitoring program, the monitoring objective is to detect any impact of the TSD unit on groundwater quality in the uppermost aquifer beneath the TSD unit. This is achieved by establishing appropriate background concentrations and statistically comparing the compliance well data to the background well data (Figure 5-1). If there is a statistically significant increase (or $\mathrm{pH}$ decrease) over background concentrations, a compliance monitoring program might be initiated. A compliance monitoring program must be initiated after the owner and/or operator cannot successfully demonstrate that a source other than the regulated unit has caused the contamination or that the increase resulted from an error in sampling, analysis, or evaluation.

In a compliance monitoring program, the monitoring objective is to determine whether groundwater protection standards have been exceeded. This is accomplished by comparing the concentration of a constituent of concern to groundwater protection standards, such as an alternate concentration 1imit, maximum concentration limit, area or natural background, health-based standards, or any other standards that constitute ajplicable, relevant, and appropriate requirements. Monitoring must continue at the TSD unit through the postclosure care period.

A third stage, a corrective action program, is initiated if a condition exists that warrants corrective action, e.g., significant exceedance of 
1

groundwater protection standards. Corrective action could consist of the removal or treatment in place of the dangerous constituents.

The remainder of this chapter includes a more specific discussion of the implementation of the Hanford Facility groundwater monitoring activities.

\subsection{EXEMPTION FROM GROUNDWATER MONITORING REQUIREMENTS [E-1]}

A waiver from the groundwater monitoring requirements as allowed under WAC 173-303-645 is not requested in the General Information Portion of this permit application. Any requests for waivers from groundwater monitoring requirements will be included in the Unit-Specific Portion of this permit application.

\subsection{INTERIM STATUS PERIOD GROUNDWATER MONITORING DATA [E-2]}

In 1986, interim status groundwater monitoring for four Hanford Facility TSD units was implemented through a Consent Agreement and Compliance Order (Ecology 1986). Three of these units are to be closed under interim status, and are not within the scope of the Hanford Facility Permit Application. As specified in the Tri-Party Agreement Action Plan, permit application documentation for the remaining unit, the Low-Level Burial Grounds, was submitted in 1989 (DOE-RL 1989a). Final status is sought for at least two other TSD units requiring gmander monitoring systems, the Grout Treatment Facility (DOE-RL 1988a) ar (DOE-RL 1991b). The initi iquid Effluent Retention Facility it application documentation for these two units was submitted in Nove. 1988 and June 1991, respectively.

The interim status groundwater monitoring program implemented for a TSD unit during the interim status period is summarized in the following sections. The information presented includes (1) a summary of the existing hydrogeologic data, (2) a description of the general well design, (3) discussion of the groundwater monitoring system design, (4) a summary of the interim status groundwater sampling and analysis plan for monitoring wells, and (5) a preliminary description of the statistical procedures used to assess water quality results. In addition, a summary is presented on the techniques and methods used to characterize the uppermost aquifer beneath the Hanford Site in support of the monitoring well system design.

\subsubsection{Interim Status Groundwater Monitoring Approach}

A specific investigative approach is taken to support the design of each TSD unit groundwater monitoring system in the interim status period. This approach consists of the following two elements.

- Establish an initial groundwater monitoring well system from which stratigraphic, hydrogeologic, and background water quality information 
can be obtained for the uppermost aquifer. Data from this initial system are used to determine the need for additional monitoring wells.

- Provide hydrogeologic properties of the uppermost aquifer system beneath the TSD unit using data collected from the monitoring well system and from previously collected or published data.

Groundwater monitoring plans are developed for each TSD unit to address these elements. These groundwater monitoring plans contain specific details regarding characterization needs and details regarding the monitoring system design. The groundwater monitoring plans also contain a sampling and analysis plan.

Groundwater monitoring plans have been developed for all three TSD units for which final status is sought. Citations for these plans are as follows: (1) Low-Level Burial Grounds (WHC 1989c); (2) the Grout Treatment Facility (WHC 1989a), and (3) Liquid Effluent Retention Facility (WHC 1991C). Two assessment monitoring plans also have been prepared for the Low-Level Burial Grounds (WHC 1990b, 1990c).

As part of groundwater monitoring system installation, subsurface sediment samples usually are collected during drilling at each well location. These samples, if collected, are described and classified in the field. Selected samples are submitted to a laboratory for analyses to determine various physical and chemical parameters.

Data collected from installation of the monitoring system and from previously collected or published data are summarized in a characterization. report. Characterization reports have been completed for all three TSD units for which final status is sought and are summarized in the respective Part $B$ permit application documentation (i.e., Low-Level Burial Grounds, Grout Treatment Facility, and the Liquid Effluent Retention Facility).

Groundwater is collected and analyzed from monitoring wells under the interim status program. During the first year of monitoring, samples are collected quarterly to establish background water quality for each well. This background is an 'area background' as defined in the Model Toxics Control Act Cleanup Regulaitions (MTCA) (WAC 173-340-200). Statistical evaluations of subsequent data are compared with these background concentrations to provide an indication of whether dangerous constituents from the TSD unit are significantly affecting the groundwater.

The annual RCRA groundwater monitoring report provides an interpretation of the data obtained through the sampling programs for the interim status groundwater systems, including such information for the Low-Level Burial Grounds, Grout Treatment Facility, Liquid Effluent Retention Facility, and other RCRA units. Groundwater monitoring results have been, and will continue to be, reported in the annual RCRA groundwater monitoring report released by March 1 of each calendar year.

Pertinent information has been abstracted from groundwater monitoring plans and characterization reports for inclusion in te unit-specific permit 
application documentation for the Low-Level Burial Grounds, Grout Treatment 2 Facility, and Liquid Effluent Retention Facility. The annual RCRA groundwater 3 monitoring report will be the documentation used to provide updates of 4 groundwater monitoring data relevant to each of these TSD units.

\subsubsection{Investigative Methods}

The techniques and methods used to assess the hydrogeologic properties of the uppermost aquifer beneath the Hanford Site are summarized in this section. This summary includes the following:

- Sources used for existing hydrogeologic information

- Design and construction details for interim status wells

- Descriptions of investigative techniques, including geologic sampling methods, geophysical well logging methods, hydrochemical sampling methods, and hydrogeologic testing methods.

5.2.2.1 Existing Hanford Site Hydrogeologic Information. Hydrogeologic information has been collected since activities began on the Hanford Site in the mid-1940s. Much of the information on subsurface geology of the Hanford Site is derived from the analyses and interpretations of boreholes and wells completed in and around the Hanford Site. Data have been compiled into a new database, the Hanford Environmental Information System (HEIS). This more comprehensive computer database management system will accommodate all data related to environmental activities within the Hanford Site.

Borehole samples have been archived in the Hanford Geotechnical Sample Library. Geophysical logs from the boreholes are maintained by the appropriate contractor.

There are numerous reports that provide interpretations of raw data. Much of what is known about the geology, hydrology, climatology, and meteorology of the Hanford Site has been compiled in the Consultation Draft Site Characterization PIan (DOE 1988, volumes 1, 2, and 3). More recent Hanford Site studies include a summary of groundwater quality (WHC 1989b) and a compilation of semiannual water table elevation maps (WHC 1991b).

\subsubsection{General Well Design. As required by WAC 173-303-400(3)(a) and} 40 CFR 265.91, the interim status groundwater monitoring system includes the completion of monitoring wells to obtain representative groundwater samples from the uppermost aquifer beneath each of the TSD units.

In some circumstances, wells that existed before implementing the RCRA groundwater monitoring requirements are used as part of the monitoring network. Carbon steel casing frequently was used in the older wells for the permanent casing in combination with stainless steel screens. Some of the oldest wells have perforations in the carbon steel casing that act as the well screen. Authorization and criteria for using groundwater wells that existed 
before the lists of the RCRA parameters were established are provided in a letter from Ecology and the EPA dated July 16, 1990 (EPA and Ecology 1990).

Details on the individual well completion methods are provided in the TSD unit-specific groundwater monitoring plans. Specifications for well designs (e.g., WHC 1990a) and procedures for performing the well installations are contained in contractor manuals.

5.2.2.3 Well Locations. The locations of the interim status monitoring wells for the individual TSD units are documented in the TSD unit-specific groundwater monitoring plans and in the Unit-Specific Portion of this permit application.

5.2.2.4 Downgradient and Upgradient Interim Status Wells. At least one monitoring well is installed hydraulically upgradient from each TSD unit. The number, location(s), and depth(s) must be sufficient to yield groundwater samples that are representative of the area background groundwater quality in the uppermost aquifer beneath the TSD unit and not impacted by the TSD unit.

There must be at least three groundwater monitoring wells located hydraulically downgradient at the limit of the waste management area (e.g., point of compliance) (Figure 5-1). The number, locations, and depths of the wells are designed for the detection of any statistically significant amount of dangerous waste constituents that might migrate from the TSD unit to the uppermost aquifer.

The upgradient and downgradient well locations for each TSD unit are selected on the basis of water table elevations and any other applicable information available at the time of well installation. Well locations and lengths of screens could be adjusted to accommodate changing water level conditions. The we 11 locations for TSD units are found in the interim status groundwater monitoring plans and in the Unit-Specific Portion of this permit application.

5.2.2.5 General Hydrogeologic Investigative Techniques. Characterization of the hydrogeologic properties of TSD units on the Hanford Facility might be based on information gained from borehole sediment samples, geophysical logging, aquifer testing, water level measurements, and other pertinent sources of information.

Borehole sediment samples can be collected using any of three different sampling methods: split-barrel core, drive-barrel grab samples, and hard-tool and bailer grab samples. Alternative sampling methods can be used as appropriate. Samples usually are collected at 5-foot (1.52-meter) intervals. Additional samples are collected at lithologic contacts, in moist zones, and in zones where organic substances are detected. The following describes the testing that could be conducted on selected sediment samples:

- Field Tithologic characterization

- Laboratory petrographic and mineralogic analyses (thin sections, $x$-ray diffraction, $x$-ray fluorescence) 
- Grain-size distribution

- Field moisture content

- Water retention capacity

- Calcium carbonate content

- Total and inorganic carbon analysis

- Cation exchange capacity

- Hydraulic conductivity.

Field moisture content, water retention capacity, and hydraulic conductivity analyses usually are not performed on bailed samples because of the high degree of physical disturbance. The unit-specific permit application documentation contains details regarding sample collection intervals and tests performed.

Historically, the following types of geophysical borehole logging were available and might have been conducted:

- Natural gamma (gross gamma ray)

- Porosity (neutron-epithermal neutron)

- Density (gamma-gamma).

Currently, gross gamma ray logging is the primary geophysical tool used. Usually during construction, the borehole is logged with a gross gamma probe after each size of temporary casing is placed and again on completion of the well. Other tools available that might have been used are a downhole video camera, caliper logging tool, and spectral gamma ray logging tool.

Limited hydraulic properties have been obtained from field determinations as well as permeameter testing in the laboratory. Aquifer testing (constantdischarge production and recovery phases) was performed primarily before 1989. Increased restrictions on purgewater disposal resulted in the use of alternative testing methods from 1989 through September 15, 1991. During this period, slug testing was the preferred method used to obtain field information on the aquifer properties. This method entailed instantaneously changing the aquifer hydraulic head by suddenly removing a cylinder of known volume. The water level recovery response was observed over time. Descriptions of the test method used to obtain hydraulic property information are provided in unit-specific permit application documentation.

\subsubsection{Interim Status Data}

Groundwater monitoring activities performed during the interim status period are summarized in this section. 
5.2.3.1 Sampling and Analysis Plan. Sampling and analysis plans are found in the unit-specific groundwater monitoring plans. The aspects of the groundwater sampling and analysis plans that have been and currently are being used for the interim status program monitoring wells are described in this section. Representative groundwater samples from the uppermost aquifer beneath the Hanford Facility are obtained and analyzed for the purpose of detecting potential contaminant releases from TSD units. All interim status sampling activities on the Hanford Facility currently are performed in accordance with SW-846 protocol or an EPA-approved method (EPA 1986b).

The interim status groundwater sampling program is designed to provide initial water quality information on groundwater in the uppermost aquifer beneath the TSD units. Dedicated sampling equipment is provided for most of the wells, thus minimizing the potential for cross-contamination between the wells. The dedicated components of the system consist of a pump, well cap, sampling manifold, and access for a water-level measurement device.

The static water-level is measured before obtaining groundwater samples. The well is purged to obtain a representative sample. The samples are collected and submitted for analyses. Samples are collected in accordance with established procedures (PNL 1989a). The following sections describe the general methods used in the acquisition of groundwater samples.

5.2.3.1.1 Static Water-Level Measurements. The static water level is measured, recorded, and remeasured until reproducible results are obtained before purging or sampling monitoring wells. Steel tape measurements are taken as depth-to-water from the top of the well casing and are subtracted from the surveyed elevation of the casing to obtain the elevation of the water leve1. Measurements are reported to the nearest 0.01 foot ( 0.3048 centimeter) and are repeated until two readings agree to within plus or minus 0.02 foot ( 0.6096 centimeter) .

5.2.3.1.2 Well Purging. Interim status monitoring wells are purged before sample collection to obtain groundwater samples that are representative of groundwater rather than of the stagnant water from the well casing. Groundwater that has occupied the well undergoes chemical changes that cause its composition to differ from that of true groundwater. Monitoring wells are purged until a minimum of three casing volumes of water have been removed from the well. The pumping rate during purging is approximately 3 to 5 gallons (11 to 19 liters) per minute for high-yield wells. If a monitoring well is not capable of sustaining this extraction rate, the pumping rate is reduced. Purging of low-yielding monitoring wells (i.e., wells that are pumped dry) will consist of removing all standing water.

5.2.3.1.3 Sample Withdrawal. Water samples are withdrawn from the well after the monitoring well has been purged. Multiple groundwater samples are obtained for laboratory analyses during the sampling event. Samples typically are collected and bottled in the following order:

- Bottles with septum caps (volatiles)

- Unfiltered samples (major-ions, cyanide, semivolatiles, metals)

- Filtered samples (metals). 
5.2.3.1.4 Field Analyses. Temperature, $\mathrm{pH}$, and specific conductivity are measured and recorded during well purging and sample withdrawal. Groundwater samples for laboratory analys is are not collected until each of these parameters has stabilized (PNL 1989a).

5.2.3.1.5 Sample Preservation and Handling. Prelabeled sample bottles containing the appropriate preservative are supplied for each monitoring well. The containers for samples that are to be analyzed for volatile and semivolatile organic compounds and total organic halogen are filled so that the meniscus of the fluid is above the rim of the sample container to ensure that there is no free head space.

Sample bottles are placed in sealed, insulated coolers immediately after collection and packed with ice to cool the samples to approximately $40^{\circ} \mathrm{F}$ $\left(4^{\circ} \mathrm{C}\right)$ as required in SW-846 (EPA 1986b). The samples are transported to the laboratory for analysis.

5.2.3.1.6 Chain of Custody. Chain-of-custody procedures are followed in collecting interim status data to ensure the compositional integrity of groundwater samples from the time of collection through laboratory analysis and data reporting. This program involves the use and control of sample labels, sample seals, field record forms, chain-of-custody forms, sample analysis request forms, and laboratory acceptance procedures.

5.2.3.1.7 Quality Assurance and Quality Control Procedures. Quality assurance and quality controi procedures are applied to both field and laboratory interim status data to ensure the reliability and validity of the data. Data quality requirements such as PARCC parameters and detection limits are addressed in the Quality Assurance Project Plan for RCRA Groundwater Monitoring Activities (WHC 1990d, as amended). The Tri-Party Agreement (Article XXXV, Paragraph 101, Article XXX, Paragraph 94, and Sections 6.5 and 7.8 of the Tri-Party Agreement Action Plan) also specify qual ity assurance and quality control requirements that are to be implemented. Site-specific quality assurance and quality control procedures for the groundwater monitoring program are documented in the Quality Assurance Project Plan for RCRA Groundwater Monitoring Activities (WHC 1990d, as amended) and in the RCRA Groundwater Monitoring Projects Quality Assurance Project Plan (PNL 1989b, as amended). Criterion for the monitoring of field and trip blanks, interlaboratory samples, and other quality control measures (e.g., blind spiked samples, field duplicates) is described in a QAPJP (WHC 1990d, as amended).

5.2.3.1.8 Disposal of Purgewater. Disposal of purgewater is determined by analytical results of the groundwater. If the analytical results exceed the criteria established in Strategy for Handling and Disposing of Purgewater on the Hanford Site Washington (WHC 1989d) appended to the Tri-Party Agreement, the purgewater is contained. A11 other purgewater is returned to the ground or as specified in the strategy document (WHC 1989d).

5.2.3.2 Analytical Data. Analytical data on the interim status groundwater program are presented in the following sections. 
5.2.3.2.1 Groundwater Elevations. Groundwater elevation data have been obtained for the interim status wells since RCRA groundwater monitoring began. Water levels also are available for existing wells prior to the RCRA groundwater monitoring program. Water level data are compiled into the HEIS database. Hanford Sitewide groundwater maps are produced semiannually. Site-specific water level data for RCRA units are documented quarterly and groundwater elevation maps are produced annually (refer to quarterly and annual reports for RCRA groundwater monitoring).

5.2.3.2.2 Results of Water Quality Analyses--Quarterly Samples. Quarterly samples are collected for the first year to establish background water quality. Constituents analyzed for are specified by 40 CFR 265.92 (b)(1)(2)(3). Specific analytical parameters are specified in unit-specific permit application documentation. After the first year, the wells are monitored for 40 CFR 265.92 (b) (2) groundwater quality parameters annually and 40 CFR 265.92 (b) (3) indicator parameters and site-specific parameters semiannually. The TSD units in assessment level monitoring require sampling quarterly. The constituents analyzed for are detailed in unit-specific permit application documentation.

All groundwater quality data from the monitoring well network are entered into a database for permanent storage and are published in quarterly groundwater monitoring reports.

5.2.3.2.3 Scatistical Results. Statistical analyses of the sampling results for indicator parameters (including $\mathrm{pH}$, specific conductivity, total organic carbon, and total organic halogens) are discussed in unit-specific permit application documentation. Detailed statistical analysis methods have been documented (WHC 1991d). Results of statistical analyses are presented in a RCRA groundwater monitoring annual report (e.q., DOE-RL 1991a).

\subsection{AQUIFER IDENTIFICATION [E-3]}

The characteristics of the uppermost aquifer beneath the Hanford Site, and regional hydrogeologic factors influencing this aquifer are sumnarized in the following section. This summary begins with a orief description of the regional physiographic and geomorphic setting of the Hanford Site. The climate and meteorology of the region also is summarized to address aquifer recharge potential from precipitation. An overview of the regional geologic framework follows, as this framework provides a major influence on aquifer characteristics. A description of the physical characteristics of the uppermost aquifer and a summary of groundwater travel time determinations comprise the remainder of this section. Hydrogeologic terms used in this discussion are defined in the glossary contained in Appendix 1B. A brief parenthetical explanation follows the initial use of these terms within the text.

The hydrogeologic information for the Hanford Site discussed in this section also applies to the Hanford Facility, unless otherwise designated. 


\subsubsection{Physiographic and Geomorphic Setting}

This section addresses the physiographic and geomorphic setting of the Hanford Site, or a description of the nature and origin of landforms. The Hanford Site is situated within the Pasco Basin of south-central Washington (Figure 5-3). The Pasco Basin is one of a number of topographic (1 and configuration) depressions located within the Columbia Plateau Physiographic Province (Figure 5-4). The Pasco Basin is bounded on the north by the Saddle Mountains, on the west by Umtanum Ridge, Yakima Ridge, and the Rattlesnake Hills, and on the south by Rattlesnake Mountain, all anticlinal folds of the Yakima Fold Belt (a physiographic subdivision of the Columbia Plateau characterized by anticlinal upwarps and synclinal downwarps of the underlying bedrock). The Pasco Basin is bounded on the east by the Palouse slope, a monocline (broad fold) that inclines to the east (Figure 5-3).

Surface topography seen at the Hanford Site is the result of: (1) anticlinal ridges, (2) Pleistocene cataclysmic flooding (flooding resulting from glacial activity occurring north of the Hanford Site 10,000 to 13,000 years ago), (3) Holocene eolian activity (relatively recent wind activity), and (4) landsliding. Since the end of the Pleistocene, winds have locally reworked the flood sediments, depositing dune sands in the lower elevations and loess (windblown silt) around the margins of the Pasco Basin. Sand dunes have largely stabilized except where these dunes have been reactivated because of the disturbance of anchoring vegetation (WHC 1991a).

\subsubsection{Climate and Meteorology}

The Hanford Site is in a semiarid desert area. The climate in the vicinity of the Hanford Site is largely influenced by the rain-shadow effect of the Cascade Range located in western Washington. This effect results in cold air drainage across the region that largely controls the wind regime of the Hanford Site.

Climatological data have been collected at the Hanford Meteorological Station, located between the 200 Areas, since 1945 (Cushing 1988).

Temperature and precipitation data alse are available from nearby locations for the period 1912 through 1943. A summary of these data through 1980 has been published by Stone et al. (1983). Data from the Hanford Meteorological Station are representative of the general climatic conditions for the region and describe the specific climate of the 200 Areas Plateau.

5.3.2.1 Wind. Prevailing wind directions on the 200 Areas Plateau are from the northwest in all months of the year (Chapter 2.0, Figure 2-3). Secondary maxima occur for southwesterly winds.

Monthly average wind speeds are lowest during the winter months, averaging 6 to 7 miles ( 10 to 11 kilometers) per hour, and highest during the summer, averaging 9 to 10 miles (15 to 16 kilometers) per hour. Wind speeds that are well above average usually are associated with southwesterly winds. However, the summertime drainage winds generally are northwesterly and

52 frequently reach 31 miles (50 kilometers) per hour. Estimates of wind 
1 extremes have been summarized by Stone et a1. (1983). Information on the

2 likelihood and frequency of strong winds and tornados in the region have been 3 summarized in a final environmental impact statement (DOE 1987), the Hanford 4 Meteorological Station climatological summary (Stone et al. 1983), and by the 5 National Severe Storms Forecast Center.

5.3.2.2 Temperature and Humidity. Ranges of daily temperatures vary from normal maxima of $35.6^{\circ} \mathrm{F}\left(1.6^{\circ} \mathrm{C}\right)$ in early January to $95^{\circ} \mathrm{F}\left(35^{\circ} \mathrm{C}\right)$ in late July. The record maximum temperature is $114.8^{\circ} \mathrm{F}\left(46^{\circ} \mathrm{C}\right)$, and the record minimum temperature is $-27^{\circ} \mathrm{F}\left(-32.7^{\circ} \mathrm{C}\right)$.

The annual average relative humidity at the Hanford Meteorological station is 54 percent. It is highest during the winter months, averaging approximately 75 percent, and lowest during the summer months, averaging approximately 35 percent.

5.3.2.3 Precipitation. Precipitation measurements have been made at the Hanford Meteorological Station since 1945. Average annual precipitation at the Hanford Meteorological Station is 6.3 inches (16 centimeters) per year. Most of the precipitation occurs during the winter, with nearly half of the annual amount occurring in the months of November through February. Days with greater than 0.5 inch ( 1.3 centimeter) precipitation occur less than 1 percent of the year. Rainfall intensities of 0.5 inch ( 1.3 centimeter) per hour persisting for 1 hour are expected once every 10 years. Rainfall intensities of 1 inch (2.54 centimeter) per hour for 1 hour are expected only once every 500 years. Winter monthly average snowfall ranges from 0.3 inch ( 0.76 centimeter) in March to 5.3 inch ( 13.5 centimeter) in January. The record snowfall of 24.4 inch (61.9 certimeter) occurred in February 1916. Snowfall accounts for approximately 38 percent of all precirstation during the months of December through February.

\subsubsection{Regional Geology}

The regional geology provides the framework for understanding the stratigraphic (rock layers) and structural (rock deformation) controls on the aquifers beneath the Hanford Site. An overview of the regional geology and a description of the primary stratigraphic units that comprise these aquifers are provided in this section.

The Hanford Site lies in the Pasco Basin near the eastern limit of the Yakima Fold Belt. The Pasco Basin is divided by the Gable Mountairi anticline into the Wahluke syncline to the north and the Cold Creek syncline to the south. The Pasco Basin is unde.7ain by Miocene-aged (approximately 17 to 8.5 million years before present) volcanic (molten rock) flows of the Columbia River Basalt Group and late Miocene- to Pleistocene-aged sediment: (approiimately 10.5 million to 12,000 years before present) that overlie the basalts. The basalts and sediments thicken into the Pasco Basin and generally reach maximum thicknesses in the Cold Creek syncline in the vicinity of the 200 Arsas. Hanford Site structure and stratigraphy are illustrated in

51 Figuras 5-3 and 5-5, respectively, and described in Geology and Hydrology of 
DOE/RL-91-28, Rev. 1

$05 / 28 / 93$

the Hanford Site (WHC 1991a, pp. 2-1 through 2-19). A brief review of this information follows.

The Columbia River Basalt Group is greater than 12,000 feet $(3,658$ meters) thick beneath the Pasco Basin. The sequence of volcanic flows within the Pasco Basin can be divided into the Grande Ronde, Wanapum, and Saddle Mountains formations (major rock divisions) (1isted from oldest to youngest). The youngest formation of the Group, the Saddle Mountain Basalt, is characterized by a sequence of volcanic flows and intercalated sedimentary units called interbeds.

Late Miocene to Quaternary sediments overly the basalts. Most of this sedimentary sequence can be divided into two main units: the Ringold Formation of late Miocene to middle-Pliocene age (approximately 10.5 million to 3 million years before present) and the Hanford formation of Pleistocene to Recent age (approximately 1 milition to 12,000 years before present).

The Ringold Formation was formed by fluvial-lacustrine (stream-lake) processes. This formation comprises the basal part of the sedimentary sequence above the basalt. The Ringold Formation is up to 600 feet (185 meters) thick at the Hanford Site in the deepest part of the Cold Creek syncline south of the 200 West Area, and up to 560 feet (170 meters) thick in the western Wahluke syncline. The Ringold Formation pinches out against Gable Mountain, Yakima Ridge, Saddle Mountains, and Rattlesnake Mountain anticlines. The Ringold Formation is largely absent in the northern and northeastern parts of the 200 East Area and adjacent areas to the north in the vicinity of West Lake, located south of Gable Mountain. The Ringold Formation is composed of semi-indurated (semi-hardened) clay, silt, mud, fine- to coarse-grained sand, and granule to cobble gravel that usually are divided into (1) gravel, sand, and paleosols (buried soils) of the basal unit; (2) clay and silt of the lower unit; (3) gravel of the middle unit; (4) mud and lesser sand of the upper unit; and (5) basaltic detritus of the fanglomerate unit (detritus deposited from stream action at the foot of a slope) (DOE 1988, volume 1, pp. 1.2-121 to 1.2-129).

Other less extensive stratigraphic units within the Pasco Basin overlie the Ringold Formation and underlie the Hanford formation. These units include a laterally discontinuous Plio-Pleistocene unit, an early 'Palouse' soil, and pre-Missoula gravels. The pre-Missoula gravels are approximately equivalent in age to the early 'Palouse' soil and Plio-Pleistocene unit.

The Hanford formation was formed by glaciofluvial processes. During Pleistocene glaciation, eastern Washington was subjected to a number of cataclysmic floods which resulted from the breakup of ice dams impounding glacial lakes in Idaho, Montana, and northeastern Washington. The Hanford formation generaliy can be divided into two main facies (1ateral subdivisions if rock type): coarse-grained or gravelly deposits and largely clast free fine-grained or sandy and silt deposits. The Hanford formation al so is commoniy divided into two informal members: the Pasco gravels and the Touchet beds (DOE 1988, volume 1, Pp. 1.2-132). The Pasco gravels generally correspond to the graveliy facies, and the Touchet beds correspond to the sandy to silty facies. The Hanford formation is thickest in the Cold Creek 
bar in the vicinity of 200 West and 200 East where the formation is up to 210 feet (64 meters) thick. Hanford formation deposits are absent on ridges approximately 1,180 feet (360 meters) above sea leve1.

Holocene surficial deposits consist of silt, sand, and gravel that form a thin [less than 16-foot (4.9-meter)] veneer across much of the Pasco Basin. These sediments were deposited by a mix of eolian and alluvial processes during the past 10,000 years.

\subsubsection{Regional and Hanford Site Hydrology}

The regional and Hanford Site surface and groundwater hydrology are discussed in the following sections. Primary surface-water features associated with the Hanford Site are the Columbia and Yakima Rivers, and their major tributaries, the Snake and Walla Walla Rivers. With regards to groundwater hydrology, the uppermost aquifer at the Hanford Site is primarily in the Ringold Formation and the vadose zone (unsaturated zone above the water table) is primarily in the Hanford formation. The Hanford formation comprises the upper 30 to 300 feet ( 9 to 91 meters) of the vadose zone throughout most of the Hanford Site, but extends below the regional water table in the 200 East Area and eastward towards the Columbia River.

5.3.4.1 Surface Hydrology. Surface drainage enters the Pasco Basin from several other surrounding basins. Within the Pasco Basin, the Columbia River is joined by major tributaries including the Yakima, Snake, and Walla Walla Rivers. Two intermittent streams traverse through the Hanford Site: Cold Creek and Dry Creek. Water drains through these creeks during the wetter winter and spring months. No perennial streams originate within the Pasco Basin.

Total estimated precipitation over the Pasco Basin averages 6.3 inches (16 centimeters) per year (Section 5.3.2.3). Mean annual run-off from the Pasco Basin is estimated to be less than $2.5 \times 10^{4}$ acre-feet per year, or approximately 3 percent of the total precipitation. The remaining precipitation is assumed to be lost through evapotranspiration with a small component (perhaps less than 1 percent) contributing to recharging of the groundwater system (DOE 1988, volume 2, p. 3.1-6).

Primary surface-water features associated with the Hanford Site are the Columbia and Yakima Rivers, and their major tributaries, the Snake and Walla Walla Rivers. West Lake, about 10 acres (4 hectares) in size and less than 3 feet $(0.9$ meter) deep, is the only natural lake within the Hanford Site. Waste water ponds, cribs, and ditches associated with nuclear fuel reprocessing and waste management activities also are present on the Hanford Site.

5.3.4.2 Groundwater. An aquitard is defined as a less permeable (water transjort capability) bed in a stratigraphic sequence. A confined aquifer system is an aquifer confined between two aquitards. A semiconfined aquifer system has some areas where the confining layer(s) might be absent.

Representatives of these aquifer types are found beneath the Hanford Site. 
Confined and semiconfined aquifer systems occur beneath the Hanford Site in the basalt flow tops, flow bottom zones, and sedimentary interbeds (DOE 1988, volume 2, pp. 3.6-1). These deeper aquifers are intercalated with aquitards consisting of basalt flow interiors. Vertical flow across the aquitards within the basalt aquifer system is inferred from water level or potentiometric surface data, but the leakage is not quantified and direct measurements are not available (DOE 1988, volume 2, p. 3.6-17). The multiaquifer system within the Pasco Basin has been conceptualized as consisting of four primary hydrogeologic units: (1) Hanford and Ringold Formation sediments, (2) Saddle Mountain Basalt, (3) Wanapum Basalt, and (4) Grande Ronde Basalt. The discussion in the following sections focuses on the uppermost aquifer systems within the Ringold and Hanford formations and within the Saddle Mountains Basalt, the aquifer comprised of the Rattlesnake Ridge interbed.

\subsubsection{Uppermost Aquifer}

The unconfined to semiconfined aquifer associated with the sedimentary units stratigraphically above the basalts is the uppermost regionally extensive aquifer beneath the Hanford Site. The water table ranges in depth from 0 feet (meters) at West Lake and the Columbia and Yakima Rivers, to greater than 350 feet (106.7 meters) near the center of the Hanford Site. Groundwater within this aquifer system is contained within the glaciofluvial sands and gravels of the Hanford formation and the fluvial-lacustrine sediments of the Ringold Formation. The position of the water table beneath the western portion of the Hanford Site is generally within the middle Ringold unit. In the northern and eastern portions of the Hanford Site, the water table is generally within the Hanford formation. Hydraulic conductivities for the Hanford formation [2,000 to 10,000 feet (610 to 3,048 meters) per day] are much greater than those of the middle unit of the Ringold Formation [610 to 3,050 feet (186 to 930 meters) per day] (Law et a1. 1987). Stratigraphic divisions of these units and their hydrologic properties are discussed in detail in the geology and hydrology of the Hanford Site (WHC 1991a, Pp. 2-5 to 2-16, pp. 3-4 to 3-26).

This aquifer system is approximately 500 feet (152 meters) thick near the center of the Pasco Basin. Laterally, the aquifer system is bounded by anticlinal basalt ridges that extend above the water table. A generalized east-west geologic cross section showing the position of the water table and major stratigraphic units beneath the Hanford Site is presented in Figure 5-6.

The base of the uppermost aquifer generally is regarded as the basalt surface. On a local scale where tha Ringold Formation is present, the silts and clays of the lower Ringold and the fine-grained facies of the basal Ringold form a confining layer. Thus, in the strict sense, the groundwater is unconfined above this layer and semiconfined below this layer.

Water levels in the uppermost aquifer have risen because of artificial recharge mechanisms such as excessive application of imported irrigation water or impoundment of streams. Waste water ponds on the Hanford Site have artificially recharged the suprabasalt (sediments found above the basalt) 
aquifer below the 200 East and 200 West Areas. Recharge from the 200 Areas waste water disposal units is estimated to be approximately 10 times the natural recharge on the Hanford Site (Graham 1981). The increase in water table elevations was most rapid from 1950 to 1960 and apparently stabilized between 1970 and 1980, when only small increases in water table elevations occurred. Waste water discharges from the 200 West Area significantly were reduced in 1984 and the water levels there are now slowly declining. A similar situation is expected to occur in the 200 East Area on the future discontinued use of the B Pond System (refer to Figure 5-9).

The general direction of groundwater flow is primarily from natural recharge areas west of the Hanford Site to discharge areas toward the Columbia River. The general west-to-east flow pattern is interrupted locally by the groundwater mounds in the 200 Areas. From the 200 Areas, there is also a component of groundwater flow to the north, between Gable Mountain and Gable Butte. Figure 5-7 illustrates the water table conditions beneath the Hanford Site.

Hydraulic conductivities for the Hanford formation [2,000 to 10,000 feet (610 to 3,048 meters) day] are much greater than those of the middle member of the Ringold Formation [9 to 230 feet (2.7 to 70 meters) day] (Graham 1981). The main body of the unconfined aquifer occurs within the middle member of the Ringold Formation. The effective porosity for the sediments in the unconfined aquifer ranges between 10 percent and 30 percent (Graham 1981).

Details of the hydrology for TSD units for which final status is sought (as of March 15, 1993) are provided in the unit-specific groundwater monitoring plans and permit application documentation.

\subsubsection{Uppermost Confined Aquifer}

The Rattlesnake Ridge aquifer is the uppermost confined aquifer system that occurs beneath the Hanford Site. This aquifer consists of the flow bottom of the Elephant Mountain Basalt, the flow top of the Pomona basalt, and the Rattlesnake interbed. The thickness of the Rattlesnake Ridge interbed, which is the principal transmissive zone within the aquifer, ranges from 50 to 82 feet (15 to 25 meters) beneath the 200 Areas and generaliy thickens toward the west (Graham 1981, Graham et a1. 1984). Erosional windows (gaps in the rock) in the Elephant Mountain basait confining layer exist locally. This could allow hydraulic communication between the Rattlesnake Ridge aquifer and the overlying unconfined aquifer (Graham et al. 1984).

Natural recharge to the Rattlesnake Ridge aquifer occurs in the higher elevations surrounding the Pasco Basin to the west, north, and northeast. The flow of groundwater generally is toward the northeast beneath the 200 West Area and possibly east to north beneath the 200 East Area (Figure 5-8). The aquifer is heterogeneous in composition because the aquifer consists of a basalt flow top and flow bottom, a clayey basalt conglomerate, an epiclastic fluvial-floodplain unit, an air-fall tuff, and a volcaniclastic unit derived from fluvial reworking of the tuff and detrital sediments (Graham et al. 
DOE/RL-91-28, Rev. 1

$05 / 28 / 93$

1984). This heterogeneity produces variability of groundwater flow through the aquifer (Graham et a1. 1984).

\subsubsection{Groundwater Travel Times}

The travel time of groundwater from the Hanford Site to the Columbia River is the sum of the time required for the contaminant to travel through the vadose zone to reach the water table and the time required for the contaminant to travel in the groundwater to the Columbia River. Travel time determinations can be based on small- or large-scale field measurements of transport rates or on calculations supported by laboratory scale measurements of the transport parameters.

The parameters that affect the travel time in the unconfined aquifer are the following:

- Distance

- Permeability

- Porosity

- Hydraulic gradient

- Dispersivity

- Retardation

- Heterogeneity (geologic structure).

In addition to these parameters, the vadose zone travel times are further affected by the relative permeability, the moisture content, and the recharge rate. Because of the variability of the sediments, the calculation of travel times based on laboratory derived parameters is considered less accurate than the large scale. field measurements. The following sections summarizes the work that has been done in determining travel times in the vadose zone and unconfined aquifer.

5.3.7.1 Vadose Zone. The travel time through the vadose zone depends on the moisture content, which in turn depends on the recharge rate. In the cases of artificial recharge where near saturated conditions have been maintained down to the water table [e.g., B Pond (refer to Figure 5-9)], the flow velocity is nearly equal to the hydraulic conductivity of the soil column. This implies a travel time on the order of days. For other cases where the natural recharge is the driving force, the travel time becomes highly uncertain. Several calculations have been done (DOE 1987) for natural recharge in the 200 East area ranging from 0.2 inch ( 0.5 centimeter) per year to 2 inches ( 5.0 centimeters) per year. These values were chosen to reflect current and possibly future wetter conditions. The computational results indicated travel times on the order of 900 years to 100 years respectively for conservative contaminants.

5.3.7.2 Saturated Zone. More than 20 estimates of groundwater travel times from the 200 East and 200 West Areas to the Columbia River have been made by investigators using a number of different methodologies and assumptions. Freshley and Graham (1988) provided a review of the various travel time 52 estimates that have been made over the past 40 years. These estimates can be 
1

classified as being based on one of the following methods: (1) extrapolation of local groundwater velocity measurements, (2) mathematical methods, and (3) monitoring the movement of contaminant plumes.

The rate and direction of groundwater flow in the vicinity of the 100 Areas are greatly influenced by the level of the Columbia River (Section 5.3.5.1). This can severely alter the groundwater gradient and even cause flow to be reversed up to 1,000 feet (305 meters) inland during periods of high water. A similar effect occurs at the 300 Area (DOE-RL 1991a, p. 16-10).

\subsection{CONTAMINANT PLUME DESCRIPTION [E-4]}

Ecology regulations [WAC 173-303-806(4)(a)(xx)(D)] require "A description of any plume of contamination that has entered the groundwater from a regulated unit at the time that the application was submitted..." This section contains a description of contaminant plumes identified in the aquifers beneath the Hanford Site.

The status of groundwater contamination is monitored monthly. The results of the monitoring program along with isopleth maps are prepared and published annually (e.g., WHC 1993c). Contaminant plumes are primarily delineated using isopleth maps (i.e., maps with lines connecting points of equal concentration or values).

\subsubsection{Radionuclide Contamination}

Isopleth maps are prepared routinely to show radioactive tritium and gross beta radiation, and nonradioactive nitrate contamination (plumes) in the unconfined groundwater flow system beneath the Hanford Site. Although these constituents are not considered to be subject to RCRA and Ecology Dangerous Waste Regulations, a study of these plumes can be used to provide an early indication of the rate and direction of contaminant movement. An example of an isopleth map delineating a contamination plume is shown in Figure 5-9 (Evans et al. 1990, p. 2.33). This figure depicts the distribution of tritium concentrations in the unconfined aquifer in 1989. Additional information on tritium contamination is found in Westinghouse Hanford Company Operational Groundwater Status Report (WHC 1993C).

\subsubsection{Nonradioactive Contamination}

The most common nonradioactive inorganic contaminants that have been observed in groundwater are nitrate, cyanide, fluoride, and hexavalent chromium. Among the nonradioactive organic contaminants routinely observed in the groundwater samples are carbon tetrachloride, 1,1,1-trichloromethane, trichloroethylene, perchlorethylene, 1,1-dichloroethane, 1,2-dichloroethene, and chloroform (e.g., Evans et al. 1990). 
Nitrate, like tritium, can be used to define the extent of contamination because nitrate is present in many waste streams at the Hanford Site and is mobile in the groundwater (Evans et al. 1990, p. 2.28). As mentioned previously, isopleth maps are prepared routinely that show levels of nitrate concentrations in the groundwater. The configuration of the nitrate plumes is similar to that shown for tritium in Figure 5-9. Additional information on nonradioactive contamination is found in the Westinghouse Hanford Company Operational Groundwater Status Report (WHC 1993C).

It should be noted that the present extent of detectable contamination is primari $1 y^{\prime}$ the result of past liquid waste discharges to the ground.

\subsection{DETECTION MONITORING PROGRAM [E-5]}

The final status detection monitoring program is designed to detect the impact of the TSD unit on groundwater quality in the uppermost unconfined aquifer beneath the unit. The final status detection monitoring program contains details regarding the following:

- Design of the monitoring well network (number and locations of monitoring wells, well construction)

- Frequency of groundwater monitoring

- Type and behavior of chemical parameters that will be used to indicate the presence of groundwater contamination

- Sampling, analysis, and statistical procedures that will be used

- Methods by which regular determinations of the groundwater flow rate and direction will be determined.

A description of unit-specific monitoring networks is found in the UnitSpecific Portion of this permit application. Final status requirements are applicable to TSD units on incorporation into the Hanford Facility Permit.

The following sections provide the necessary data and information to support the implementation of a final status detection monitoring program at each TSD unit.

\subsubsection{Monitored Indicator Parameters, Waste Constituents, Reaction Products [E-5a]}

The monitoring parameters are selected on the basis of their suitability to groundwater monitoring at individual TSD units, and do not necessarily apply to the entire Hanford Facility. The following criteria are considered in the selection of monitoring parameters for each TSD unit:

- Present in significant quantity within the waste that has been disposed of 
- Relative mobility and low retardation with respect to groundwater flow, and the stability and persistence in the environment

- Lack of significant natural presence of the parameters in the groundwater

- Ease of detection and minimal sampling and analytical interferences (detectability)

- Usefulness as indicators of other potential contaminants

- Lack of data interpretation problems caused by common laboratory and field contaminants.

5.5.1.1 Dangerous Waste Characterization [E-5a(1)]. A compilation of the dangerous waste that has been disposed of in each TSD unit is a part of unit-specific permit application documentation. This compilation will include, to the degree possible, compositions, quantities, and dates of waste disposal, and will form the basis for the selection of the unit-specific monitoring parameters and constituents.

\subsubsection{Behavior of Constituents [E-5a(2)]. The mobility, stability, and} persistence of waste constituents and their reaction products that have been disposed of at a TSD unit are of prime importance in determining the proper unit-specific monitoring parameters and constituents. Those constituents that generally are mobile and persistent through the soil zone and into the saturated zone are useful indicators of chemical migration from a waste disposal site.

Parameters such as distribution or sorption coefficients for inorganic (e.g., Freeze and Cherry 1979, pp. 402-408) and organic constituents (Lyman et al. 1982) and chemical solubilities are used in these evaluations. Other important properties that are considered for organic constituents are vapor pressure and the Henry's Law constant (used to evaluate to what degree compounds will be partitioned into the aqueous phase and to what degree this phase is likely to migrate as a vapor).

\subsubsection{Detectability [E-5a(3)]. The detectabilities of the groundwater} sampling parameters for each TSD unit are to be given in terms of practical quantification limits for each of the constituents listed. The practical quantification limits represent the lowest concentrations of analytes in groundwater that can be reliably determined within specified limits of precision and accuracy by the standard analytical methods under routine laboratory operating conditions. Data quality objectives regarding detection levels are addressed in a quality assurance project plan (WHC 1990d, as amended).

\subsubsection{Groundwater Monitoring Program [E-5b]}

This section describes a comprehensive program of monitoring wells for each TSD unit to be used during the final status detection monitoring program. 
The final status detection monitoring system is designed to detect the migration of chemical releases within the uppermost unconfined aquifer at compliance points immediately downgradient from potential leak sources in regulated units. The groundwater will be monitored as required during the operational period for regulated units.

5.5.2.1 Description of Wells [E-5b(1)]. The analytical basis for locating the monitoring wells around individual TSD units, and the well locations selected to achieve detection level coverage with the minimum number of wells are discussed in the following sections.

5.5.2.1.1 Background. Groundwater monitoring wells that are required to be installed will be in compliance with the detection level monitoring requirements of WAC 173-303-645(9). These wells will yield groundwater samples from the uppermost unconfined aquifer that are representative of the quality of area background water immediately upgradient of the unit and the quality of water passing beneath the unit.

5.5.2.1.2 Design Approach for Monitoring Wells. Tentative locations for monitoring wells are identified along the downgradient sides (point of compliance) of the TSD unit. Initial well locations are determined based on consideration of the interpreted direction of groundwater flow crossing the unit.

The groundwater monitoring system must be capable of yielding groundwater samples for analysis and must consist of the following:

- Monitoring wells installed hydraulically upgradient from the limit of the TSD unit. The number, location, and depths of the wells must be sufficient to yield groundwater samples that are: (1) representative of groundwater quality in the uppermost aquifer near the unit and (2) not affected by the unit.

- Monitoring wells installed hydraulically downgradient at the limit of the TSD unit. The number, location, and depth of the wells must allow for the detection of dangerous waste or dangerous waste constituents that migrate from the TSD unit to the uppermost aquifer.

- All monitoring wells must be cased in a manner that maintains the integrity of the monitoring well borehole. This casing must be screened and packed with gravel or sand, where necessary, to enable sample collection at depths where appropriate aquifer flow zones exist. The annular space above the sampling depth must be sealed with suitable material to prevent contamination of samples and the groundwater.

Existing wells might be used as part of the monitoring network provided the wells are in compliance with WAC 173-160. The reasoning behind the location of the individual wells is, or will be, included in unit-specific permit application documentation. Well remediation and abandonment will be accomplished in accordance with WAC 173-160. 
5.5.2.1.3 Well Maintenance and Remediation. Monitoring well maintenance, remediation, and abandonment will be performed in accordance with the Hanford Well Rehabilitation, Remediation, and Decommissioning Plan (WHC 1993a), WAC 173-160, and the Tri-Party Agreement.

5.5.2.1.4 Monitoring Well Locations and Design. To comply with Ecology groundwater monitoring requirements, monitoring wells at dangerous waste units are located at intervals along "the hydraulically downgradient limit of the waste management area..." [WAC 173-303-645(6)(a)]. The waste management area is defined as "the limit projected in the horizontal plane of the area on which waste will be placed during the active life of the regulated unit" [WAC 173-303-645(6)(b)]. These regulations, therefore, require that monitoring wells be placed as close as reasonably possible to the edge of the regulated unit. Installation of monitoring wells will be based on the following criteria.

- Satisfy the regulatory requirements for a groundwater monitoring system that consist of a sufficient number of wells installed at appropriate locations and depths to yield groundwater samples that:

(1) represent the composition of groundwater that has not been impacted by a TSD unit

(2) represent the composition of groundwater passing beneath the TSD unit.

- Location of monitoring wells should ensure a high level of confidence that dangerous waste migrating from a regulated unit would be reliably detected (Section 5.5.4.7).

- Wells should provide area background hydrochemical information for areas that have not been affected by leakage from a regulated unit.

- Wells should be placed in locations that will afford the collection of hydrogeologic information.

5.5.2.1.5 Monitoring Efficiency Model. The monitoring efficiency model (MEMO) was designed specifically for the well location evaluations

(Wilson et al. 1991) and based on work described in Domenico and Robbins (1985). When combined with planar and vertical flow nets, stratigraphic cross sections, and estimates of aquifer and transport properties, MEMO becomes an effective tool used for guidance in locating monitoring wells at the Hanford Site. A MEMO allows the calculation of the probability of detecting contamination released from inside the boundary of the TSD unit. Acceptable limits to this probability will be defined before the network design is initiated.

For a selected plume length, given the actual site parameters (e.g., transverse dispersivity), releases occurring at most locations with in the waste management area would be expected to be detected, but releases occurring at restricted locations between the monitoring wells and near the downgradient 52 boundary would be less likely to be detected within the same constraints. 
DOE/RL-91-28, Rev. 1

$05 / 28 / 93$

Given that monitoring wells always will be spaced some finite distance apart, and given the uncertainties inherent in predicting the behavior of a natural geologic system, a level of uncertainty always will be present in the functioning of any groundwater monitoring network design. The MEMO provides a simple way to begin to quantify the effectiveness of a given network design.

\subsubsection{Equipment Decontamination [E-5b(2)]. All field equipment} decontamination and sampling activities will comply with aspects of a health and safety plan and procedures manuals. The procedures are intended to prevent cross-contamination between boreholes during drilling activities. Field equipment decontamination activities will be documented in the field logbook.

\subsubsection{Background Values [E-5c]}

Background values are defined as the concentrations of chemical, physical, biological, or radiological constituents, or other characteristics in or of groundwater at a particular point in time and upgradient of a unit, that have not been affected by that unit. This background is regarded as an 'area background' as defined in WAC 173-340. Background groundwater qual ity for detection monitoring can be based (1) on sampling of wells that are not upgradient from the unit if hydrogeologic conditions do not allow the owner or operator to determine what wells are upgradient or (2) sampling at other wells will provide a better indication of area background groundwater composition that is as or more representative than that obtained from samples from upgradient wells [WAC 173-303-645(8)(a)(i) and (b) and 40 CFR 264.97(a)(1)].

Area background levels will be determined for final status detection-level groundwater monitoring parameters. These include general contamination indicator parameters such as specific conductance, $\mathrm{pH}$, TOC, TOX, or heavy metals and site-specific parameters (waste constituents or reaction products) that will provide a reliable indication of the presence of dangerous constituents in groundwater. The site-specific parameters (described in unit-specific permit application documentation) will be selected based on

(1) the types, quantities, and concentrations of waste constituents present;

(2) the mobility, stability, and persistence of the waste constituents;

(3) the detectability of the parameters; and (4) existing data.

Area background values address two objectives: (1) to provide information concerning the baseline values for waste constituents of concern and (2) to determine whether there is any evidence of contamination in the compliance wells (downgradient) that could result from a release from a TSD unit. To address the first objective, baseline values will be established for the final status indicator parameters (specified in unit-specific permit application documentation) from a minimum of 1 year of quarterly sampling and analysis of upgradient wells. These baseline values can be used as concentration limits in compliance monitoring [WAC 173-303-645(5)(a)(i) and WAC 173-303-645(5)(b)]. Four independent samples will be obtained at each background well during each sampling event. The downgradient wells also wili be sampled and analyzed at the same frequency during this time. For a detection monitoring program a statistical evaluation is required to address 
the second objective. Requirements for sampling frequency are discussed in Section 5.5.4.5.1. Statistical analyses are presented in Section 5.5.4.7.

Area background data subsequently will be reviewed for seasonal variations, trends, and significant differences among the wells. The background statistics and/or statistical methodology might be modified, if required, to address temporal or spatial variation. Background data also will be reevaluated if changes in groundwater flow directions result in changes in definition of upgradient wells.

\subsubsection{Sampling, Analysis, and Statistical Procedures [E-5d]}

This section provides information on the groundwater sampling, analysis, and statistical evaluation procedures that are proposed for use with the monitoring well system. The choice of an appropriate statistical test depends on the type of monitoring (i.e., detection or compliance) and the nature of the data (e.g., the proportion of values in the data set that are below detection 1imit) (Figure 5-2). Statistical procedures under final detection or compliance monitoring program status are discussed in Section 5.5.4.7 and Section 5.6.7.4, respectively. As the postclosure monitoring program will be implemented at least 30 years in the future, actual protocols and procedures likely will be equivalent to those cited in this section.

\subsubsection{Sample Collection [E-5d(1)]. The groundwater monitoring system} proposed for use at the Hanford Facility is designed to provide representative groundwater quality data from the uppermost aquifer beneath each identified TSD unit. Procedures to be followed during the collection of groundwater samples from the network have been developed and will be available to all onsite personnel and to the regulators. These procedures will be consistent with those listed in SW-846.

5.5.4.1.1 Static-Water Level Measurements. Before purging or sampling the monitoring well, the static-water elevation will be measured, recorded, and remeasured until reproducible results are obtained. The measurements will be taken as depth-to-water from the top of the well casing and the values will be subtracted from the surveyed elevation of the casing to obtain the elevation of the water table. Graduated steel measuring tapes or other approved devices will be used for the measurements. Measurements will be reported to the nearest 0.01 foot ( 0.3 centimeter).

5.5.4.1.2 Well Purging. Monitoring wells will be purged using a dedicated pump before samples are collected. This action will be taken to obtain groundwater samples that are representative of the formation water, rather than of the stagnant water from the well casing. Groundwater that has occupied the well casing for a long duration often is oxidized and might not be indicative of true formation water.

As a guideline, high-yielding monitoring wells will be purged until a minimum of three casing volumes have been removed. However, a well will not be considered ready for sample collection until concurrent measurements of $\mathrm{pH}$, specific conductivity, and water temperature have stabilized to at least plus 
or minus 10 percent over two well volumes pumped (Barcelona et al. 1985). The quantity of the casing volume is computed from the values of the casing diameter and the height of the water column in the monitoring well such that

one purge volume $=$ (total well depth - water table depth) $x$ (0.653 gallon per foot 4 -inch well)

Purging of low-yielding monitoring wells (i.e., those that are pumped dry) will consist of removing all standing water.

The pumping rate at each well will be chosen to minimize turbidity and aquifer stress. Generally, the rate of pumping during sampling will be kept below the rate used during rell development (Barcelona et al. 1985).

Water levels, pumping rates, and values of sampling parameters (i.e., pH, specific conductivity, and temperature) will be recorded in field logbooks and transferred to a sample groundwater field record form.

5.5.4.1.3 Field Analysis. During well purging and sample withdrawal, field determinations of temperature, $\mathrm{pH}$, and specific conductivity will be measured and recorded. The stabilization of these parameters will be an indication that well water has been purged and formation water is being sampled. Other methods of determining the presence of formation water (e.g., measuring the concentration of specific ionic species during the well purging process) might be proposed at a future time.

5.5.4.1.4 Sample Withdrawal. After the monitoring well has been purged, water samples will be withdrawn from the well using a dedicated pump. The sample withdrawal rate will be kept to approximately 0.26 gallon (0.98 liter) per minute as recommended for groundwater sampling when volatile organic compounds are involved (Barcelona et al. 1985).

Samples will be collected and containerized in the order of volatilization sensitivity of the parameters to be analyzed. Samples to be analyzed for volatile organic compounds or other organics will not be filtered. Samples for metals will be split and handled in accordance with Section 5.5.4.2.

5.5.4.2 Sample Preservation and Shipment [E-5d(2)]. Sample container and preservation methods that will be used during the groundwater monitoring program are in accordance with SW-846 (EPA 1986b). Measurements of pH and specific conductivity will be taken in the field on unpreserved samples.

Precleaned and prelabeled sample containers will be supplied for each monitoring well and will include the appropriate preservatives. To ensure zero head space, the containers for samples analyzed for volatile organic compounds will be filled to slightly more than full before being capped. Samples typically are collected in the following order:

- Bottles with septum caps (volatiles)

- Unfiltered samples (major-ions, cyanide, semivolatiles, metals)

- Filtered samples (metals). 
Immediately after collection, the sample containers will be placed in sealed, insulated coolers packed with ice to cool the ambient temperature to approximately $40^{\circ} \mathrm{F}\left(4^{\circ} \mathrm{C}\right)$. The samples will be transported to the laboratory for arrival within sufficient time to meet holding time requirements. Field parameter record forms and approved sample analysis request forms will be attached to the sealed containers.

5.5.4.3 Analytical Procedures [E-5d(3)]. The laboratory approved for the groundwater monitoring program will use standard laboratory procedures as listed in SW-846 or an alternate equivalent. Alternate procedures, when used, will meet the guidelines of SW-846, Chapter 1.0 (EPA 1986b).

Field split samples will be compared to determine if the results obtained from the lead laboratory are comparable to the results from other

laboratories. Comparisons will be conducted for volatile organic compounds, dissolved metals, and inorganic anions. A minimum of two different laboratories will be used for the comparison testing. If the lead laboratory results are found to be statistically different, necessary action will be initiated to investigate and/or correct the situation.

Spiked samples will be submitted to the lead laboratory to estimate the bias of analytical laboratory procedures. Spiked samples could consist of metals, herbicides, pesticides, volatile organic compounds, and other constituents. The spiked samples will be prepared with materials issued by Ecology, EPA, and/or the implementing DOE-RL contractor.

Duplicate analyses of field samples will be conducted to estimate the variability of laboratory measurements. Trip blanks and field blanks also will be prepared for analys is along with the principal groundwater samples. At least one trip blank will be prepared for each transported shipment of groundwater samples. At least one field blank will be prepared for each sample batch or at the rate of one blank for every 20 samples collected.

5.5.4.4 Chain of Custody [E-5d(4)]. Chain-of-custody procedures will be followed to ensure the integrity of groundwater samples and to trace the possession and handling of the individual samples from the time of collection through laboratory analyses and data reporting. A single form will be used for each sample transport shuttle and will trace the handling of as many samples as possible. Each person handling one or more of the listed samples on the form will sign and return a copy of the form to the implementing DOE-RL contractor identified on the top line of the form.

Additional quality assurance and quality control procedures include sample labels, sample seals, field logbooks, sample analysis reyuest sheets, and laboratory notebooks.

\subsubsection{Additional Requirements for Compliance Point Monitoring [E-5d(5)].} Compliance point monitoring could be required for some TSD units. The

49 following sections discuss additional requirements for this compliance point 50 monitoring. 
5.5.4.5.1 Sample Frequency [E-5d(5)(a)]. In compliance with regulations, all wells (compliance and background) will be sampled at least semiannually during detection monitoring [WAC 173-303-645(9)(d) and 40 CFR 264.98(d)] and during the active and postclosure period of each TSD unit. During each sampling event, a sequence of four samples will be taken from each we11 [WAC 173-303-645(8)(g)(i) and 40 CFR 264.97(g)(1)]. These four samples will be taken at an interval that ensures, to the greatest extent technically feasible, that an independent sample is obtained. This requirement could be accomplished by reference to the uppermost aquifer's effective porosity, hydraulic conductivity, and hydraulic gradient, and the fate and transport characteristics of the potential contaminants. In hydrogeologic environments where the groundwater velocity prohibits one from obtaining four independent samples on a semiannual basis, an alternate sampling procedure approved by Ecology may be used [WAC 173-303-656(8)(g) (ii) and 40 CFR $264.97(\mathrm{~g})(2)]$. Specific sampling intervals will be presented in unit-specific permit application documentation.

5.5.4.5.2 Compliance Point Groundwater Quality Values [E-5d(5)(b)]. The groundwater quality data obtained from the compliance point monitoring wells will be documented in a form that expresses each groundwater sampling parameter, the analytical value of the concentration in groundwater from the most recent sampling event, the analytical detection limit, and the background concentration limit for each parameter. Summary statistics to be presented include the mean and variance of the sampling sequence (based on a minimum of four independent samples), the number of less-than-detection-limit values, the median, coefficient of variation, and minimum and maximum values.

\subsubsection{Annual Determination $[E-5 d(6)]$. Groundwater flow rates and flow} direction within the uppermost aquifer will be determined annually for those TSD units being monitored. Average horizontal flow rates and directions will be determined from groundwater elevation contour maps constructed after each sampling event. The velocity of flow will be determined using the Darcian flow theory:

$$
v_{h}=k_{h} i_{h} / n_{e}
$$

where

$V_{h}=$ the horizontal groundwater velocity

$K_{h}^{h}=$ the horizontal hydraulic conductivity

$i_{h}=$ the horizontal hydraulic gradient

$n_{e}=$ the effective porosity.

The value of $K_{h}$ will be determined from hydraulic property investigations performed on monitoring wells. The average value of $i_{h}$ at the location of each monitoring well will be calculated from the water table contour maps. Effective porosities range between 10 percent and 30 percent (Graham 1981, p. 3-12). These data will enable the groundwater flow velocity to be determined in the vicinity of each monitoring we 11.

Horizontal groundwater flow directions for the uppermost aquifer beneath the TSD unit being monitored will be determined from water table contour maps 
constructed for that unit. The data used to develop water table contour maps will be periodic water level measurements in various TSD unit groundwater monitoring wells. The flow directions will be qualitatively estimated by superimposing directional streamlines normal to the water table equipotential lines.

\subsubsection{Statistical Determination for Detection Monitoring Program [E-5d(7)].} Indicator parameter data from downgradient compliance point wells will be compared with the background wells (area) data semiannually to determine whether there is a statistically significant increase (or decrease for the case of $\mathrm{pH}$ ) over background concentrations. Statistical methods appropriate for a final status detection monitoring program will include analys is of variance, tolerance intervals, predication intervals, control charts, test of proportions, or other statistical methods approved by Ecology

[WAC 173-303-645(8)(h)]. The type of monitoring, the nature of the data, the proportions of nondetects, and temporal variation are important factors to consider when selecting appropriate statistical methods. The statistical evaluation procedures chosen will be based on the EPA guidance document, Statistical Analysis of Ground-Water Monitoring Data at RCRA Facilities Interim Final Guidance (EPA 1989d). Specifics will be addressed in unitspecific permit application documentation.

5.5.4.8 Reporting. The results of the statistical evaluation will be reported to Ecology in the RCRA annual groundwater monitoring reports. The statistical results might include a list of groundwater parameters analyzed, detection limits and background values for each parameter, and the quantified laboratory results. For a particular TSD unit, if a statistically significant increase in one or more of the groundwater parameters is determined, the following steps will be taken.

- Ecology will be notified in writing within 7 days of the finding with a report indicating which indicator parameters and or constituents have shown statistically significant increase over the background values. Ecology will be notified in writing in 7 days if the owner/operator intends to demonstrate that increases are caused from sources other than the regulated units, or from sampling errors, analyses, and/or evaluations.

- All monitoring wells will be sampled immediately and analyzed for all constituents 1isted in 40 CFR 264, Appendix IX, and for any other specific dangerous constituents as determined by any additional information regarding the waste managed in that TSD unit.

- Following review and validation of the Appendix IX analytical data, the compliance wells will be resampled within one month and reanalyzed for all of the compounds detected [WAC 173-303-645(9)(g)( $i i i)$ ].

- Following review and validation of the reanalyzed data, these confirmed constituents will form the basis for compliance monitoring.

- Within 90 days, a plan will be submitted to Ecology to establish a compliance monitoring program meeting the requirements of 
WAC 173-303-645(10) or 40 CFR 264.99, or the data necessary to justify that a compliance monitoring program is not required

[WAC 173-303-645(9)(g)(iv)].

\subsection{COMPLIANCE MONITORING PROGRAM [E-6]}

A compliance monitoring program will be established for a TSD unit if groundwater sampling during detection level monitoring reveals statistically significant increases (or $\mathrm{pH}$ decrease) over area background concentrations for groundwater. In a compliance monitoring program, the monitoring objective is to determine whether groundwater protection standards have been exceeded. This is accomplished by comparing the concentration of a constituent of concern to grounowater protection standa.'ds such as maximum concentration limit and alternate concentration limit; area or natural background; or applicable, relevant, and appropriate requirements.

\subsubsection{Kaste Description [E-6a]}

A list of all recorded waste handled at Hanford Facility TSD units is included in the Hanford Facility Part A Dangerous Waste Permit Application (DOE-RL 1988b). If required, additional information will be provided on (1) the results of any direct sampling of the waste, (2) a list of expected waste constituents, and (3) an estirate of the composition and physical properties of any immiscible fluids that might be expected to have been derived from the waste.

\subsubsection{Characterization of Contaminated Groundwater [E-6b]}

If a compliance level monitoring program at a given TSD unit is considered necessary, a complete characterization of groundwater will be provided in which an increase in dangerous chemicals above appropriate reference levels is indicated. The characterization of groundwater will include (1) concentrations of each constituent detected in 40 CFR 264, Appendix IX, (2) concentrations of major anions and cations, and

38 (3) concentrations of any other appropriate constituents [e.g., Table I of 39 WAC 173-303-645(5)].

\subsubsection{Dangerous Constituents to be Monitored [E-6c]}

If compliance monitoring is required at any TSD unit, data quality objectives and indicator parameters will be established. Additionally, any other Appendix IX constituents detected and confirmed will be added to the constituent list. If other groundwater constituents indicative of migrating waste products are identified, the list of groundwater parameters will be revised to include such constituents. 


\subsubsection{Concentration Limits [E-6d]}

With enactment of compliance level monitoring, maximum concentration limits will be identified for each of the groundwater monitoring parameters listed in Table 1 of WAC 173-303-645. Alternate concentration limits will be proposed after considering the observed concentrations of chemical constituents in the groundwater that might have been derived from the regulated unit in question. The area background, natural background, and other standards that are applicable, relevant, and appropriate requirements will be considered when proposing an alternate concentration limit.

If, during compliance level monitoring, the reference concentration limits for a given groundwater parameter or parameters are significantly exceeded, a corrective action program will be implemented (Section 5.7).

\subsubsection{Groundwater Monitoring System [E-6f]}

The compliance level groundwater monitoring system will be designed to determine whether groundwater protection standards have been exceeded. Thus, the compliance level groundwater monitoring system will comply with WAC 173-303-645(10) for a compliance monitoring program.

5.6.5.1 Description of Wells [E-6f(1)]. The system design will consist of those wells installed under the detection level monitoring program and any additional wells that are determined to be required after assessing the detection efficiency of the present well network.

5.6.5.2 Representative Samples [E-6f(2)]. The compliance monitoring system will be designed to provide groundwater samples that are representative of groundwater composition at the point of compliance.

\subsubsection{Location of Background Monitoring Wells that Are Not Upgradient} [E-6f(3)]. Background groundwater composition could be based on samples from wells that are not upgradient from the TSD urit. The justification of well locations for unit background water quality is addressed in unit-specific permit application documentation.

\subsubsection{Background Values [E-6g]}

Area and/or natural background concentration values will be proposed for each groundwater monitoring parameter identified for the compliance-level monitoring program. The exact sampling periods, frequencies, and statistical methods used to establish the area background values will be presented in unit-specific permit application documentation. Natural background values will be established in conjunction with the Hanford Site-wide background study. Background will be established for additional constituents identified in the Appendix IX analysis. It is anticipated that those procedures and techniques used to establish area background conditions under the final status detection-level monitoring program will be applied. 


\subsubsection{Sampling, Analysis, and Statistical Procedures [E-6h]}

A proposed sampling and analysis plan including procedures for sample collection, sample preservation and shipment, analytical methods, and chain-of-custody controls, will be prepared if compliance-level monitoring becomes necessary. The basic information for sample collection, sample preservation and shipment, analytical methods, and chain-of-custody procedures will not change from the proposed plans submitted under the detection-level monitoring program (Section 5.5). To comply with WAC 173-303-645(10)(f), the compliance-level monitoring wells will be sampled at least semiannually for the specified groundwater parameters and waste constituents. If verified groundwater monitoring results indicate that appropriate groundwater protection standards (e.g., maximum concentration limit or alternate concentration limit; or applicable, relevant, and appropriate requirements) are exceeded at any monitoring well along the line of compliance, written notification will be made to Ecology within 7 days of the finding. An application for a permit modification to establish a corrective action program (Section 5.7 ) will be submitted within 90 days

[WAC 173-303-645(10)(g)(i)(ii)]. In the case of a false positive claim, the owner/operator will not ify Ecology within 7 days in accordance with WAC $173-303-645(10)(i)(i)$.

\subsubsection{Sample Collection [E-6h(1)-(4)]. This information will not change} from the proposed plans submitted under the detection level monitoring program (Section 5.5.4).

\subsubsection{Additional Requirements for Compliance Point Monitoring [E-6h(5)]. Under compliance monitoring, additional activities will be conducted to provide a more protective monitoring program.}

5.6.7.2.1 Sample Frequency $[E-6 h(5)(a)]$. Under compliance monitoring downgradient compliance wells will be sampled semiannually [WAC 173-303-645(10)(f)].

5.6.7.2.2 Compliance Point Groundwater Quality Values [E-6h(5)(b)]. Analytical groundwater quality data will be prepared in an appropriate form for full statistical analysis. These data will exist primarily in tabular form and will consist of raw data from each independent sample obtained during each sampling event. The presentation of the statistical evaluation of the data will depend on the exact nature of the compliance limits (Section 5.6.4).

\subsubsection{Annual Determination of Hydraulic Gradient [E-6h(6)]. Under} compliance monitoring, the hydraulic gradient will be determined annually and the efficiency of the monitoring well network will be addressed. If warranted, additional monitoring wells will be installed.

\subsubsection{Statistical Determination for Compliance Monitoring Program} [E-6h(7)]. Statistical evaluation procedures under compliance monitoring program depend on the type of compliance limit. If the compliance limit is determined from the area background, the statistical method will be chosen to compare the composition of groundwater from background wells to those from compliance wells (e.g., statistical methods presenter in Section 5.5.4.7). If 
1 the compliance limit is a specified constant limit such as maximum

2 concentration limit or alternate concentration limit, the appropriate

3 statistical procedures will compare the compliance well concentrations

4 estimated from sampling with the prescribed fixed limits. The recommended

5 procedure is to compare the mean (or median) compliance well concentration

6 against the compliance limit by constructing a confidence interval

7 (EPA 1989d). If the Hanford Facility Permit requires that a compliance limit

8 is not to be exceeded more than a specified fraction of the time, then the

9 construction of tolerance limits will be the recommended procedure

10 (EPA 1989d). Specific statistical evaluation procedures will be identified in 11 unit-specific permit application documentation.

\subsection{CORRECTIVE ACTION PROGRAM [E-7]}

If, at the point of compliance, dangerous constituents are measured in the groundwater at concentrations that exceed accepted groundwater protection standards, sufficient data, supporting information, and analyses will be provided to establish a corrective action program.

A description of the groundwater monitoring plan that will be used to assess the effectiveness of the corrective action measures will be submitted. This groundwater monitoring plan will be similar in scope to a compliance level monitoring program developed under Section 5.5 and will include all relevant information pertaining to the location and description of monitoring wells, groundwater sampling and analysis plans, statistical methods, and quality assurance and quality control procedures [WAC 173-303-645(11)(d)] .

The concentrations established in the Hanford Sitewide background program in conjunction with area background concentrations will determine groundwater protection standards for each individual TSD unit. This will reduce the time and costs currently being expended for drilling and sampling unit-specific background wells, and will further benefit cleanup efforts by the uniform application of cleanup standards across the Hanford Site. The Hanford Sitewide groundwater background program is discussed in Hanford Site Groundwater Background (DOE/RL 1992b). 
Upgradient well

(IS)
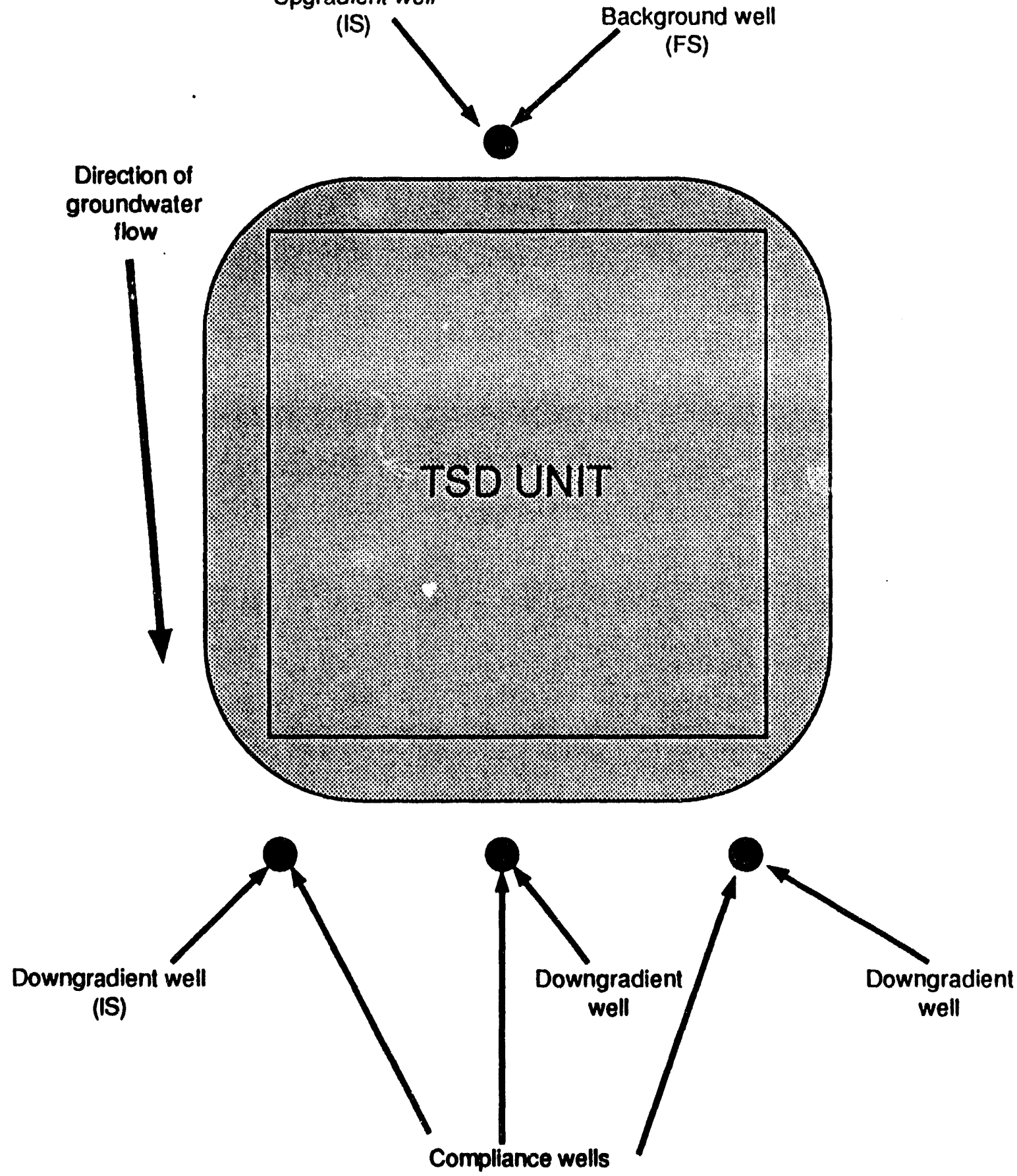

(FS)

Waste management area

[Limited projection in the horizontal plan of the area on which

waste will be placed during the active life of the regulated unit (WAC 173-303-645(6)(b).]

\section{IS = Interim status}

FS = Final status

Figure 5-1. Generalized Configuration for a Detection Monitoring Groundwater Well System. 

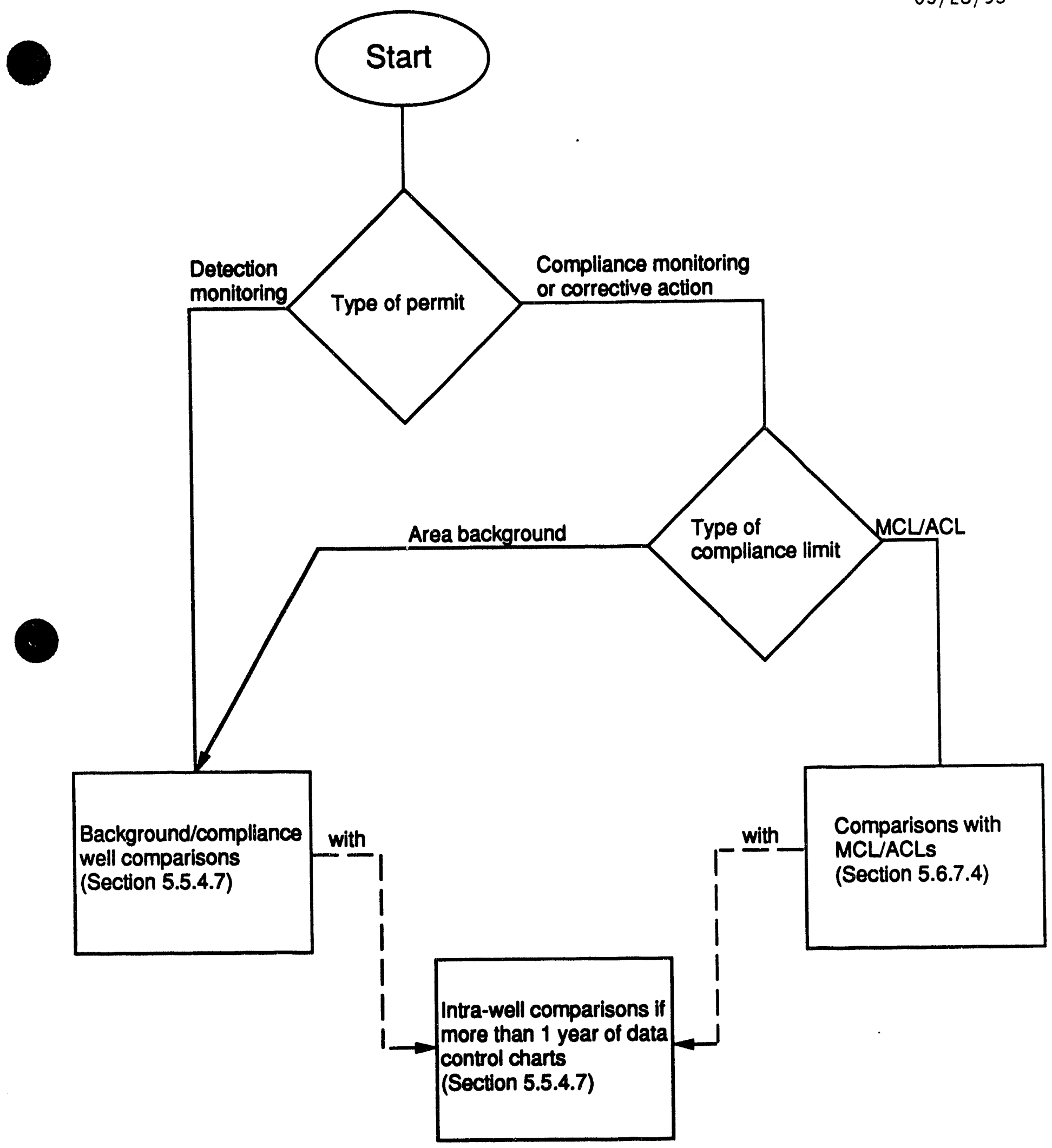

Figure 5-2. Flow Chart for Selection of Appropriate Statistical Method Used for Data Interpretation. 


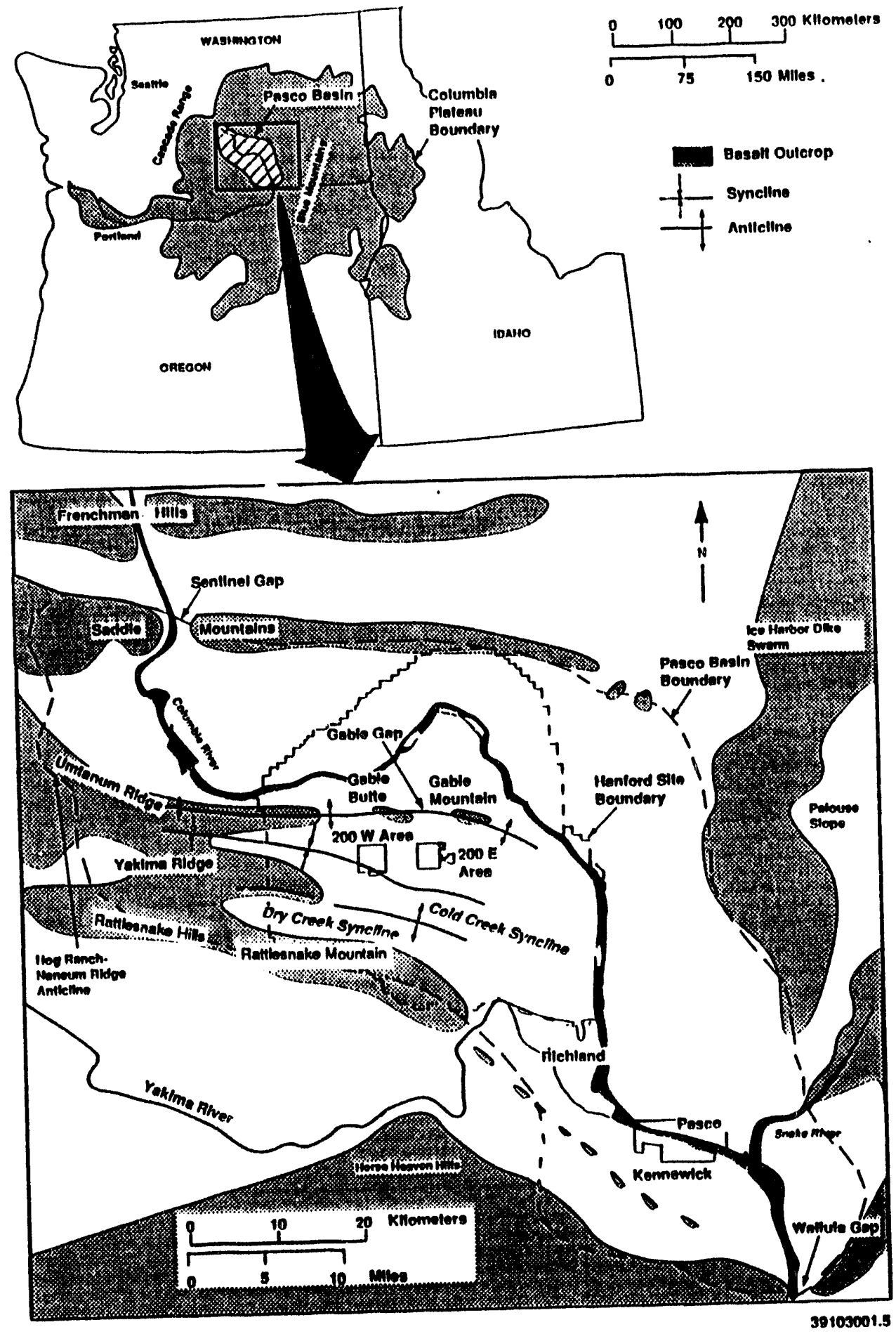

Figure 5-3. Location of Bounding Structures of the Pasco Basin. 
DOE/RL-91-28, Rev. 1

$05 / 28 / 93$

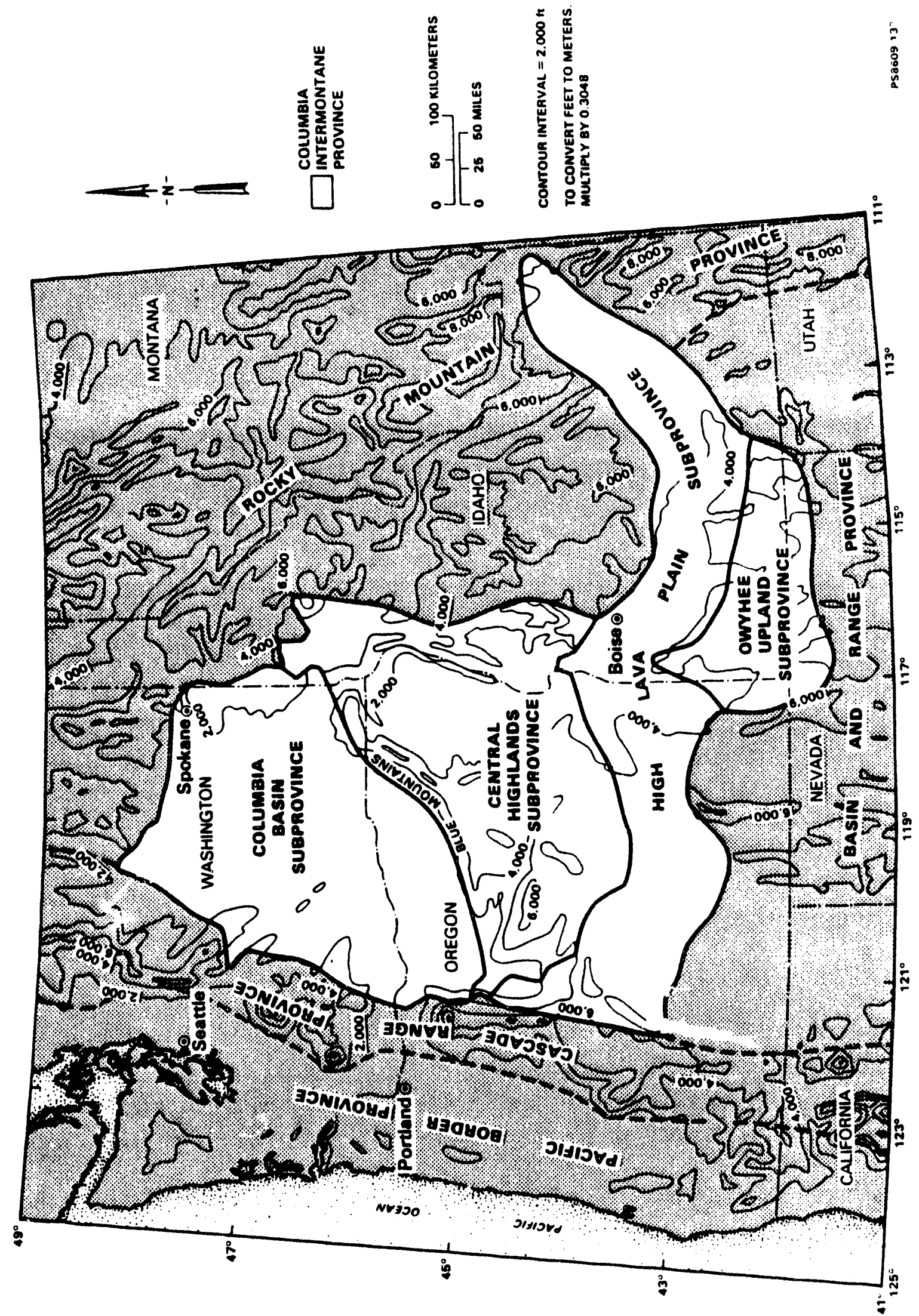

Figure 5-4. Divisions of the Columbia Intermontane Province and Adjacent Snake River Plains Province. 


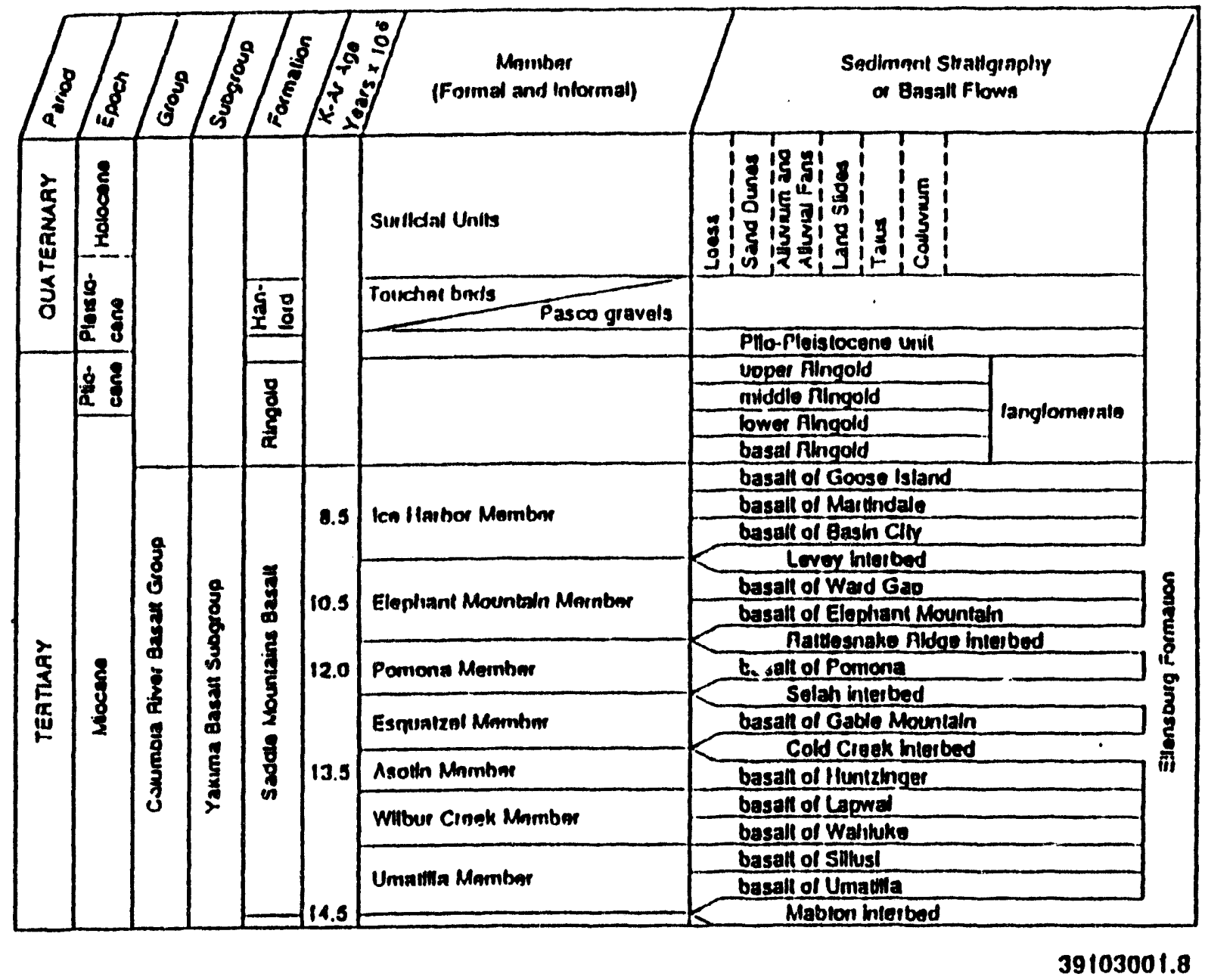

Figure 5-5. Generalized Stratigraphic Column of Formations at the Hanford Site. 

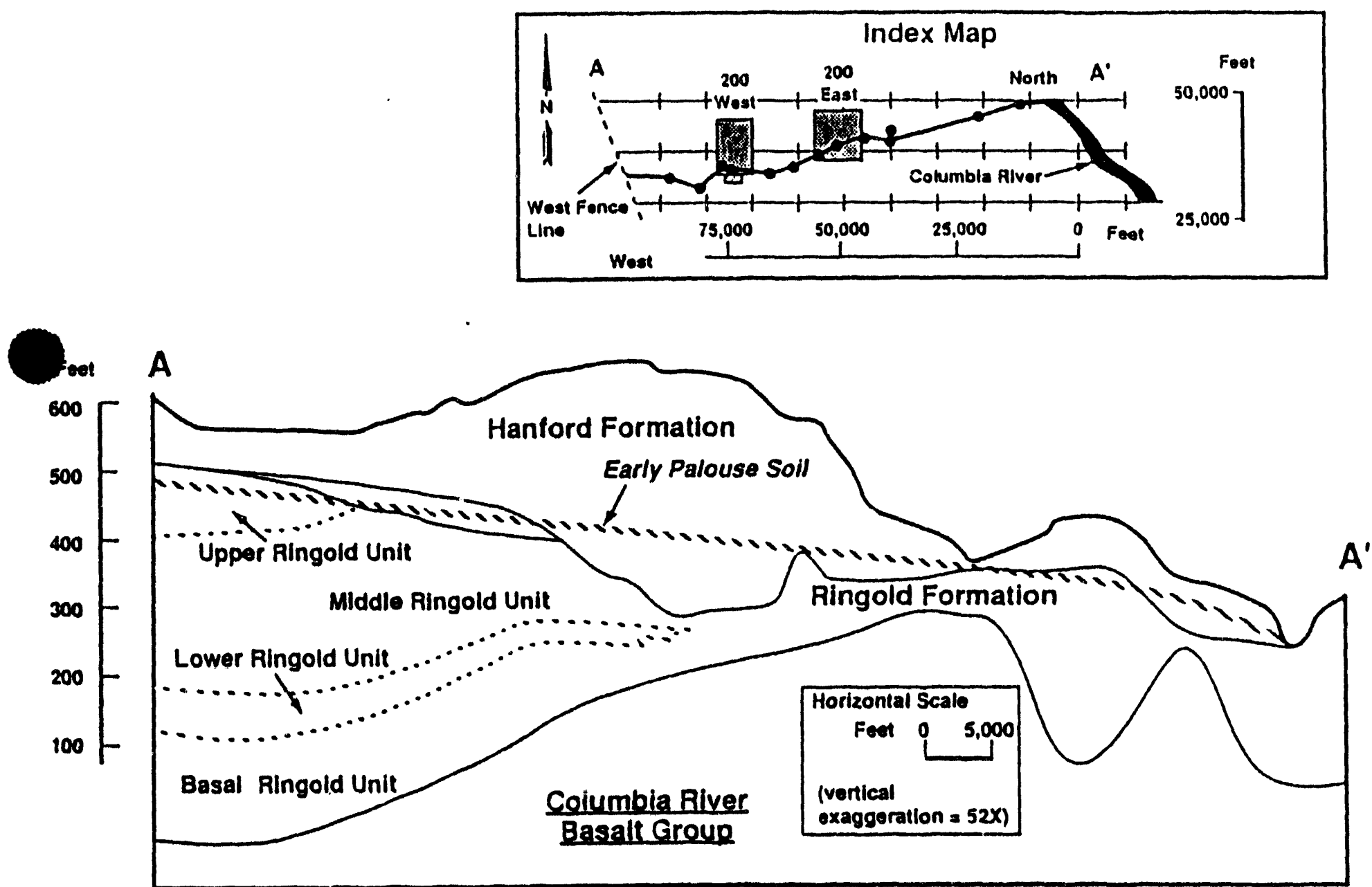

39108105.8

Figure 5-6. Generalized Geologic Cross Section Through the Hanford Site (after Tallman et al. 1979, p. 20). 


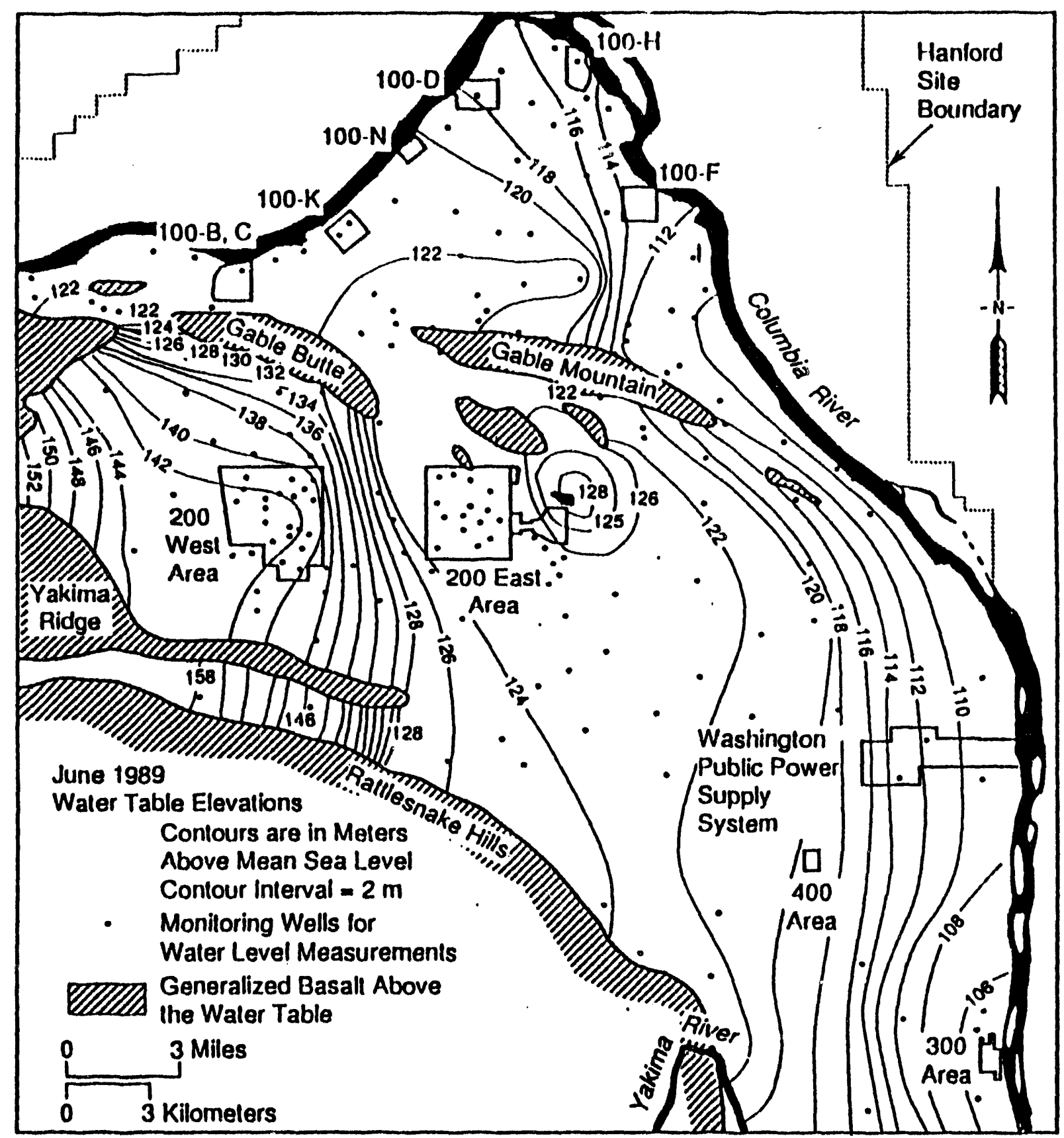

H9104011.2

Figure 5-7. Water Table Map of the Hanford Site (June 1979) (Smith and Gorst 1990). 
DOE/RL-91-28, Rev. 1

$05 / 28 / 93$

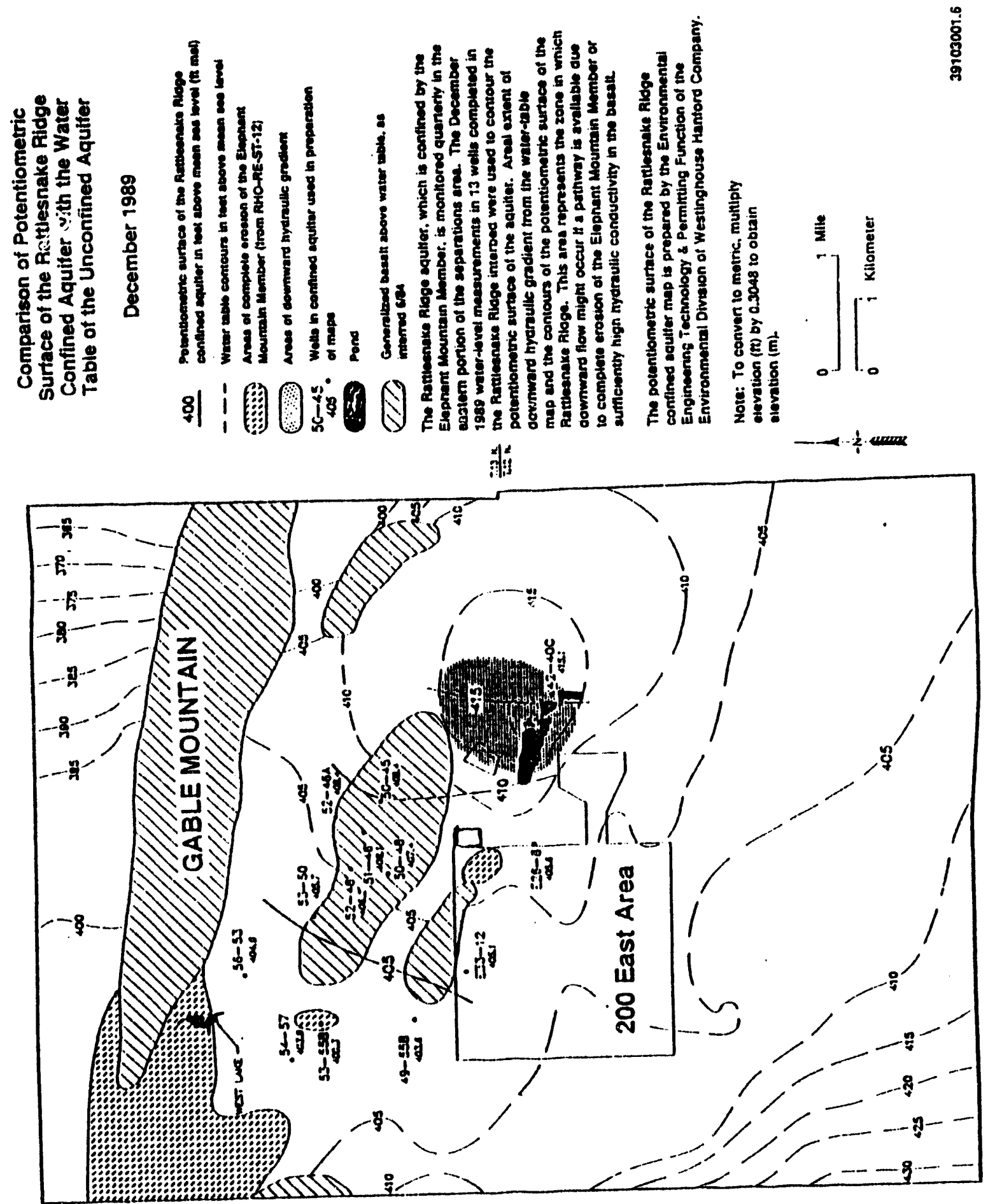

Figure 5-8. Potentiometric Surface of the Rattlesnake Ridge Aquifer Beneath the Hanford Site. 


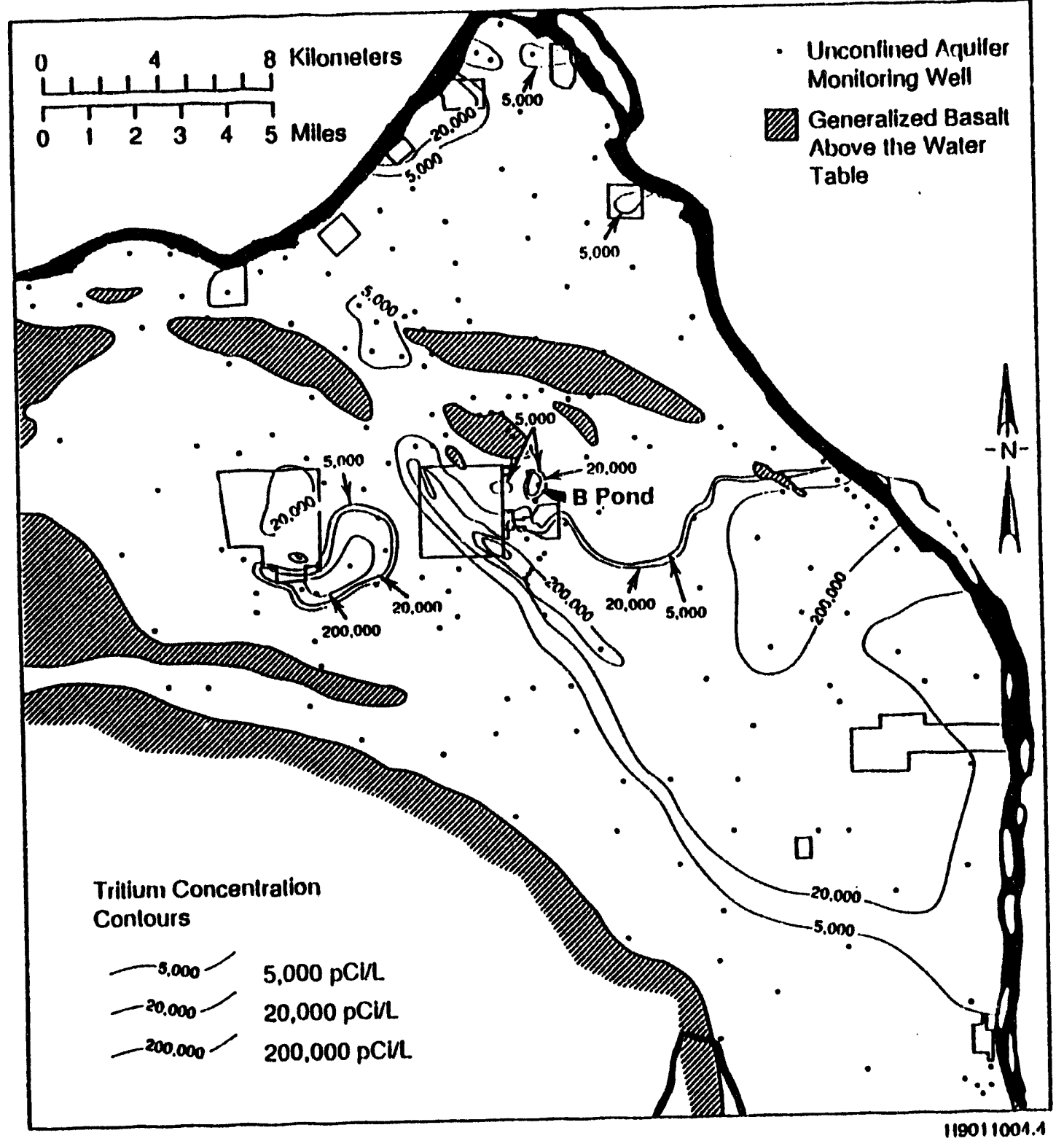

Figure 5-9. Distribution of Tritium on the Hanford Site, 1989 (Evans et al. 1990). 


\section{CONTENTS}

6.0 PROCEDURES TO PREVENT HAZARDS [F] . . . . . . . . . . . . . . . . 6-1

6.1 SECURITY $[F-1]$................... . . 6-1

6.1.1 Security Procedures and Equipment [F-1a] . . . . . . 6-1

6.1.1.1 24-hour Surveillance System $[F-1 a(1)] . . .6-1$

6.1.1.2 Barrier and Means to Control Entry

$[F-1 a(2),(2 a),(2 b)] . . . . . . . .6-1$

6.1 .1 .3 Warning Signs [F-1a(3)].......... 6-1

6.1 .2 Waiver $[F-1 b, b(1), b(2)]$........... 6-2

6.2 INSPECTION SCHEDULE [F-2].............. . . 6-2

6.3 WAIVER OR DOCUMENTATION OF PREPAREDNESS AND PREVENTION

REQUIREMENTS [F-3] .................. 6-2

6.4 PREVENTIVE PROCEDURES, STRUCTURES, AND EQUIPMENT [F-4] . . . . 6-3

6.5 PREVENTION OF REACTION OF IGNITABLE, REACTIVE, AND

INCOMPATIBLE WASTES $[F-5] . . . . . . . . . . . . .66-3$ 
DOE/RL-91-28, Rev. 1

$05 / 28 / 93$

1

2

3

4

5

This page intentionally left blank. 


\subsection{PROCEDURES TO PREVENT HAZARDS [F]}

The Hanford Facility is operated to minimize exposure of the general public and operating personnel to dangerous waste. This chapter describes the security, inspection frequencies and procedures, and emergency response equipment available to prevent, minimize, and control exposure of the general p'sblic and operating personnel to dangerous waste.

\subsection{SECURITY [F-1]}

The following sections describe the security measures, equipment, and warning signs used to control entry to the Hanford Facility. Security measures, equipment, and warning signs used to control entry to individual TSD units are provided in the Unit-Specific Portion of this permit application.

\subsubsection{Security Procedures and Equipment [F-1a]}

The following sections describe the 24-hour surveillance system, warning signs, and barriers used to provide security and controlled access to the Hanford Facility.

6.1.1.1 24-hour Surveillance System [F-1a(1)]. The entire Hanford Facility is a controlled access area. The Hanford Facility maintains around-the-clock surveillance for protection of government property, classified information, and special nuclear materials. The Hanford Patrol maintains a continuous presence of protective force personnel to provide additional security.

6.1.1.2 Barrier and Means to Control Entry [F-1a(2);(2a),(2b)]. The majority of TSD units for which final status is sought are located within, or in the vicinity of, the 200 Areas (Table 2-1). Manned barricades are maintained around the clock at checkpoints on vehicular access roads leading to these areas (Yakima and Wye Barricades, drawing H-6-958 in Appendix 2A). A11 personnel accessing the Hanford Site areas must have a U.S. Department of Energy-issued security identification badge indicating the appropriate authorization. Personnel also might be subject to a random search of items carried into or out of the Hanford Site. Additional means to bar entry or control access (e.g., fences, locked entry doors) are discussed in the UnitSpecific Portion of this permit application.

6.1.1.3 Warning Signs $[\mathrm{F}-1 \mathrm{a}(3)]$. Signs are, or will be, posted at area boundaries within the Hanford Site stating "NO TRESPASSING. SECURITY BADGES REQUIRED BEYOND THIS POINT. VEHICLES ONLY. PUBLIC ACCESS PROHIBITED" (or an equivalent legend).

In addition, warning signs stating "DANGER--UNAUTHORIZED PERSONNEL KEEP OUT" (or an equivalent legend) are, or will be, posted at TSD units within the Hanford Facility. These signs are, or will be, written in english, legible 
DOE/RL-91-28, Rev. 1 $05 / 28 / 93$ from a distance of 25 feet ( 7.6 meters), and visible from all angles of
approach.

\subsubsection{Waiver $[F-1 b, b(1), b(2)]$}

Waivers of the security procedures and equipment requirements for the Hanford Facility currently are not requested.

\subsection{INSPECTION SCHEDULE [F-2]}

The TSD unit-specific inspection plans are included in the Unit-Specific Portion of this permit application.

\subsection{WAIVER OR DOCUMENTATION OF PREPAREDNESS AND PREVENTION REQUIREMENTS [F-3]}

The emergency preparedness and prevention measures taken for the Hanford Facility are described in the Unit-Specific Portion of this permit application. Most of the Hanford Facility TSD units are equipped with internal communication systems to relay emergency or other information to unit personnel. The internal communication systems include telephones, various alarm systems, and hand-held or vehicle two-way radios. Alarm systems exist at various locations throughout the Hanford Facility to allow personnel to respond appropriately to various emergency situations, including the following: building evacuations, take-cover events, and fire and/or explosion. Telephones are located throughout the Hanford F cility and provide both internal and external communication. In addition, the iollowing external communication systems are available for notifying persons assigned to emergency response organizations:

- Fire alarm pul1 boxes and fire sprinkler flow monitoring devices-connected to a system monitored around the clock by the Hanford Fire Department

- Telephone number 811--contact point for the Hanford Site; on notification, the Hanford Patrol Operations Center notifies and/or dispatches required emergency responders

- Telephone number 373-3800--single point of contact for the operations and engineering contractor emergency duty officer; this number can be dialed from any Hanford Facility telephone

- Telephone number 375-2400--single point of contact for the research and development contractor emergency duty officer; this number can be dialed from any Hanford Facility telephone

- Crash alarm telephone system--consists of selected telephones that are disassociated from the regular system and are connected automatically to control stations 
- Two-way radio system--consists of hand-held or vehicle radios; the system accesses the Hanford Facility emergency network and can summon the Hanford Fire Department, Hanford Patrol, and/or any other assistance needed to deal with emergencies.

\subsection{PREVENTIVE PROCEDURES, STRUCTURES, AND EQUIPMENT [F-4]}

The preventive procedures, structures, and equipment used on the Hanford Facility are described in the Unit-Specific Portion of this permit application. Preventive procedures are in place to ensure that unloading activities are conducted in a safe manner and that run-off of liquid, if spilled during waste unloading operations, are contained and disposed of properly. In those areas of TSD units where significant risk of exposure exists, personnel are required to wear protective suits and/or respiratory devices, depending on the specific hazard that could exist. Procedures are in place at specific TSD units to provide backup power to equipment critical to unit operation.

A plan also is in place to address response measures to control and mitigate effects to human health and the environment for any spi11 or release between TSD unit boundaries (e.g., onsite transportation) (Chapter 7.0).

\subsection{PREVENTION OF REACTION OF IGNITABLE, REACTIVE, AND INCOMPATIBLE WASTES [F-5]}

The Unit-Specific Portion of this permit application describes procedures and precautions to prevent the reaction of ignitable, reactive, and incompatible waste at TSD units for which final status is sought. 
DOE/RL-91-28, Rev. 1

$05 / 28 / 93$

1

2

3

4

5
This page intentionally left blank. 
$\mathrm{DOE} / \mathrm{RL}-91-28, \operatorname{Rev} .1$ $05 / 28 / 93$

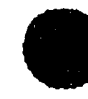

7.0 CONTINGENCY PLAN [G] . . . . . . . . . . . . . . . . . . 7-1

CONTENTS

APPENDIX

9

10

11

7A HANFORD FACILITY CONTINGENCY PLAN

APP $7 A-i$ 
$\mathrm{DOE} / \mathrm{RL}-91-28, \operatorname{Rev} .1$
$05 / 28 / 93$

This page intentionally left blank. 


\subsection{CONTINGENCY PLAN [G]}

The WAC 173-303 requirements for a contingency $p l a n$ are satisfied by the Hanford Facility Contingency Plan (Appendix 7A), together with each TSD unitspecific contingency $p l a n$ contained in the Unit-Specific Portion of this permit application. Appendix $7 A$ includes response to a nonradiological hazardous materials spill or release at Hanford Facility locations not covered by TSD unit-specific contingency plans or building emergency plans. The 10 Hanford Facility Contingency Plan also includes response to a spili or release

11 as a result of transportation activities, movement of materials, packaging, 12 and storage of hazardous materials. 
DOE/RL-91-28, Rev. 1

$05 / 28 / 93$

1

2

3

4

This page intentionally left blank. 
DOE/RL-91-28, ReV. 1

$05 / 28 / 93$

\section{CONTENTS}

8.0 PERSONNEL TRAINING [H] .................... . 8-1 5 6 
This page intentionally left blank. 
DOE/RL-91-28, Rev. 1

$05 / 28 / 93$

\subsection{PERSONNEL TRAINING [H]}

The training programs for individual TSD units for which final status is sought can be found in the Unit-Specific Portion of this permit application. These programs contribute to the assurance that TSD units are operated and maintained in accordance with reguirements of the EPA, Ecology, the Occupational Safety and Health Administration, and the U.S. Department of Energy.

The training programs are overseen by the DOE-RL and prepare employees to operate and maintain Hanford Facility TSD units in a safe, efficient, and environmentally sound manner. In addition to preparing employees to operate and maintain the TSD units under normal conditions, the programs ensure that employees are prepared to respond in a prompt and effective manner should offnormal or emergency conditions occur. Emergency response training is consistent with emergency responses outlined in the Hanford Facility Contingency Plan (Appendix 7A) and in TSD unit-specific contingency plans.

The Hanford Site contractors are responsible for developing and administering the courses required by the training programs. The TSD unit management is responsible for identifying TSD unit-and job-specific training requirements for TSD unit employees and for ensuring that employees complete the appropriate training.

Each Hanford Site contractor maintains official training files in a centralized location. These files include employee training records, course attendance rosters, and course outlines. Training records are maintained by the contractors' organizations in accordance with the requirements of the Privacy Act of 1974. Presently, the training records of individual employees are avallable for inspection purposes through the Freedom of Information Act of 1966. The DOE-RL is seeking authorization through the U.S. Department of Energy-Headquarters to amend the systems notice under the Privacy Act to allow regulatory agencies 'routine use' access to training records under this act. Training records on current and former employees will be maintained in accordance with Chapter 12.0. 
DOE/RL-91-28, Rev. 1

$05 / 28 / 93$

CONTENTS

9.0 EXPOSURE INFORMATION REPORT . . . . . . . . . . . . . . . 9-1 
DOE/RL-91-28, Rev. 1 $05 / 28 / 93$

This page intentionally left blank. 
TOE/RL-91-28, Rev. 1

$05 / 28 / 93$

\subsection{EXPOSURE INFORMATION REPORT}

Requirements for submittal of exposure information are contained in 40 CFR 270.11. Such information must be included in a Part B permit application submitted by an owner or operator for a facility that stores, treats, or disposes of hazardous waste in a surface impoundment or a 1 andfill. The information provided is to be "reasonably ascertainable" and must address, at a minimum, the following:

- Reasonably foreseeable poten;ial releases from both normal operations and accidents at the unit, including releases associated with transportation to or from the unit;

- The potential pathways of human exposure to hazardous wastes or constituents resulting from these releases; and

- The potential magnitude and nature of the human exposure resulting from such releases.

Further guidance on the submittal of exposure information is provided in the Permit Applicants' Guidance Manual for Exposure Information Requirements under RCRA Section 3019 (EPA Guidance Manual) (EPA 1986a). The EPA Guidance Manual states that the purpose of the exposure information report is to identify and characterize the magnitude of human exposure resulting from contaminant releases or potential releases from the units under evaluation, and to determine if there is a "significant potential risk" to public health. The EPA Guidance Manual cites three criteria that must be considered in evaluating the potential for human exposure.

- A release of hazardous waste or hazardous constituents must have occurred.

- The release must have moved offsite via an environmental pathway (groundwater, surface water, or air).

- A nearby population must be affected by such a release.

These criteria form the basis for the exposure information reports included in the Unit-Specific Portion of this permit application. Hanford Facility units currently requiring such a report include the Grout Treatment Facility, the Low-Level Burial Grounds, and the Liquid Effluent Retention Facility. The Double-She11 Tank System might be added to this 1 ist at a later time, if it is determined that portions of the Double-She 11 Tank System will undergo landfill closure. The Purgewater Storage Unit might also be added, if the Part A permit application, Form 3, for this unit is not withdrawn. Ali these units are located within or near the 200 Areas of the Hanford Site.

The EPA Guidance Manual states that the "EPA does not expect applicants to develop major, expensive new pieces of information..." to prepare the exposure information report. Therefore, the exposure information reports contained in the Unit-Specific Portion of this permit application are 
1 developed primarily around available information. The information addresses

2 reasonably foreseeable potential releases from both normal operations and

3 accidents. This information also includes releases associated with potential

4 environmental transport pathways and routes of human exposure to dangerous

5 waste or constituents or the dangerous waste component of mixed waste. 
$\mathrm{DOE} / \mathrm{RL}-91-28, \mathrm{Rev} .1$

\section{CONTENTS}

10.0 WASTE MINIMIZATION ....................... 10-1

5 
DOE/RL-91-28, Rev. 1

$05 / 28 / 93$

1
2
3
4
5

This page intentionally left blank. 


\subsection{WASTE MINIMIZATION}

Requirements relevant to waste minimization are contained in 40 CFR 264.73(a) and 264.73(b) (9). The requirements of 40 CFR.264.73(a) state that the "owner or operator must keep a written operating record at his facility." The requirements of $264.73(\mathrm{~b})(9)$ mandate:

"a certification by the permittee no less often than annually, that the permittee has a program in place to reduce the volume and toxicity of hazardous waste that he generates to the degree determined by the permittee to be economically practicable; and the proposed method of treatment, storage or disposal is that practicable method currently available to the permittee which minimizes the present and future threat to human health and the environment."

To fulfill the requirements of $264.73(b)(9)$, a certification that the Hanford Facility has a waste minimization program in place is entered, annualiy, into the Hanford Facility operating record (Chapter 12.0). 
D0E/RL-91-28, Rev. 1

$05 / 28 / 93$

1
2
3
4
5

This page intentionally left blank. 
11.0 CLOSURE AND POSTCLOSURE REQUIREMENT [I] . . . . . . . . . 11-1

11.1 CLOSURE OPTIONS ................... 11-1

11.1 .1 Clean Closure .............. 11-2

11.1 .2 Health-Based Closure ............. 11-2

11.1 .3 Landfill Closure ............... 11-3

11.2 CLOSURE PERFORMANCE STANDARDS ........... . 11-3

11.2.1 Minimizing the Need for Future Maintenance . . . . 11-4

11.2.2 Protection of Human Health and the

112 Environment ............ . 11-4

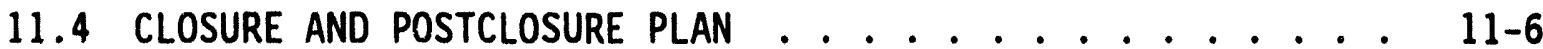

11.4.1 Closure Plan .............. 11-6

11.4.1.1 Closure Schedule .......... 11-6

11.4.1.2 Extension for Closure Time ...... 11-6

11.4.1.3 Amendments to Closure Plan ...... 11-6

11.4.1.4 Certification of Closure ....... 11-6

11.4.1.5 Survey Plat . . . . . . . . 11-7

11.4.1.6 Notice to Local Land Authorities . . . 11-7

11.4 .2 Postclosure Plan .............. 11-7

11.4.2.1 Inspection P $\mathrm{P}$ an ......... 11-7

11.4.2.2 Groundwater Monitoring P1 an ..... 11-7

11.4.2.3 Maintenance Plan ........... 11-7

11.4.2.4 Provisions to Amend Postclosure Plan: 11-8

11.4.2.5 Certification of Completion of

Postclosure Care ......... 11-8

11.5 POSTCLOSURE PERMIT APPLICATION DOCUMENTATION $\ldots \ldots$. . . 11-8

11.5.1 Provisions to Amend Postclosure Permit

Application Documentation ........ 11-8

11.5.2 Certification of Completion of

Postclosure Care ............ 11-8

11.6 NOTICE IN DEED . . . . . . . . . . . . . . 11-9

11.7 CLOSURE COST ESTIMATES . . . . . . . . . . 11-10

11.8 POSTCLOSURE COST ESTIMATES . . . . . . . . . . 11-10 
DOE/RL-91-28, Rev. 1 $05 / 28 / 93$

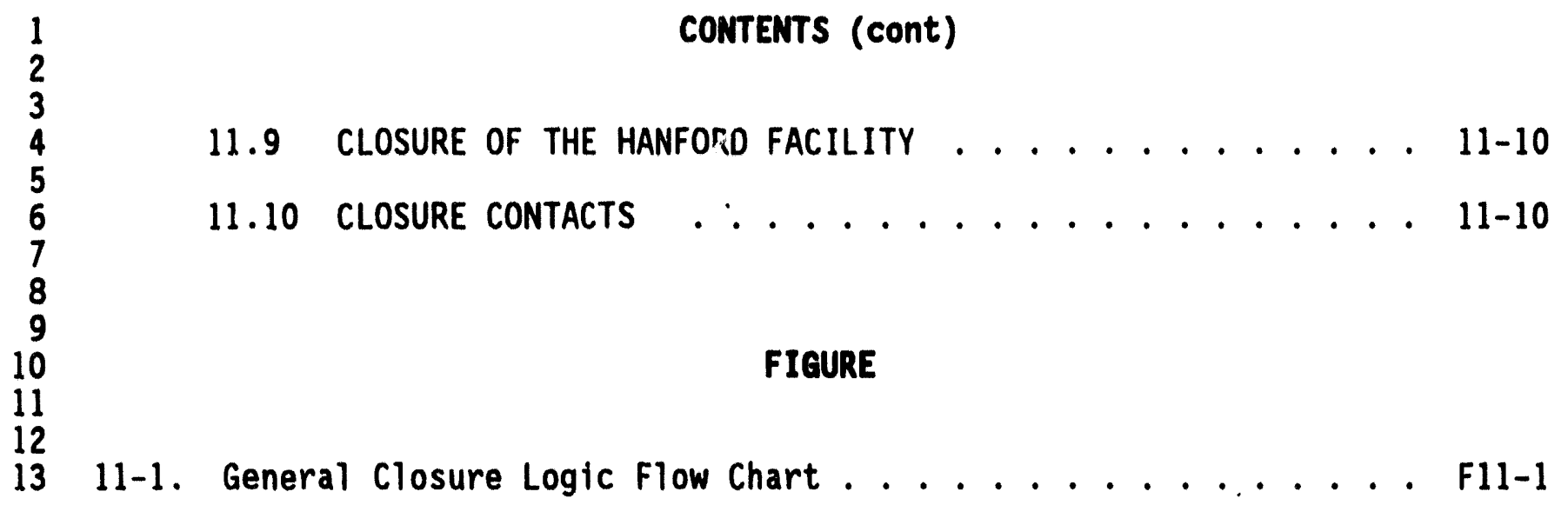


DOE/RL-91-28, Rev. 1

$05 / 28 / 93$

\subsection{CLOSURE AND POSTCLOSURE REQUIREMENT [I]}

This chapter describes the general activities and objectives common to closures of Hanford Facility TSD units for which final status is sought. If closure of TSD units will leave waste in place, then postclosure documentation al so will be included in the Unit-Specific Portion of this permit application. This chapter addresses closure options, closure performance standards, closure activities, closure and postclosure plans, postclosure permit application documentation, and closure of the Hanford Facility. As noted in Chapter 1.0, interim status closure and postclosure plans are not part of this permit application.

When a TSD unit is no longer used to treat, store, and/or dispose of dangerous or mixed waste, the TSD unit is closed. Closure is required to be accomplished in a manner that is protective of human health and the environment. Closure of the TSD units within the Hanford Facility is conducted in accordance with the current regulations contained in 40 CFR 264 through 268 and 40 CFR 270, WAC 173-303, and the requirements of the Tri-Party Agreement. The term 'RCRA closure', as used in this chapter, refers to considerations of both federal and state regulations, as applicable.

In addition, RCRA closures of TSD units within the Hanford Facility must be integrated with remediation of any surrounding past-practice units. This integration is addressed in the Tri-Party Agreement in Article III, Article IV, Article XXIV, Article XXXII, and in Section 5.5 of the Tri-Party Agreement Action Plan.

On the Hanford Site, there are over 1,000 past-practice units. These past-practice units are organized into areas called operable units that contain all of the individual TSD units (Appendix 2A). The past-practice units will be remediated either under the CERCLA regulations or the RCRA corrective action regulations. These regulations, although based on protection of human health and the environment, might not require the same performance standard as for a RCRA TSD closure. Integration of the remediation of past-practice operable units with TSD closures will require RCRA TSD units located within past-practice operable units to have the same cleanup standards. This integration will eliminate the possibility of having different cleanup standards for coincident or adjacent parcels of 1 and. Ongoing discussions are taking place with the EPA and Ecology to address RCRA and CERCLA integration needs. The contents of this chapter will be updated, through the permit modification process if necessary, to incorporate the results of these discussions.

\subsection{CLOSURE OPTIONS}

Currently, there are three RCRA closure options: clean closure, healthbased closure, and landfill closure. All of the TSD units are within the Hanford Site past-practice (RCRA and CERCLA) operable units. Because of this, activities and cleanup standards for remediation of the past-practice operable 
1

2

3

11

12

units should take precedence when integrated with the closure of RCRA TSD units.

Specific closure activities and objectives for any one TSD unit will be included in the Unit-Specific Portion of this permit application. Figure 11-1 shows a general closure logic flow chart.

The following sections address the three closure options: clean closure, health-based closure, and landf 111 closure.

\subsubsection{Clean Closure}

Clean closure requires that all dangerous waste constituents and contamination be removed and disposed of in accordance with applicable regulations. Clean closure is accomplished by verifying that the potentially dangerous constituents treated, stored, and/or disposed of at the TSD unit being closed are not present above action levels for those potential contaminants. Action levels are concentrations of analytes of interest that prompt an action, such as soil removal/treatment or further evaluation. Initial action levels will be the greater of two levels: background or limit of quantitation. Background will be Sitewide background threshold values as defined in Hanford Site Soil Background (DOE-RL 1992c). The limit of quantitation is the level above which quantitative analysis can be obtained with a specific degree of confidence (generally the mean background signal plus 10 standard deviations). If concentrations exceed initial action levels, health-based action levels will be assessed.

In some instances, samples obtained at a TSD unit for closure will be compared to local background instead of the Hanford Site background. Local background refers to the concentrations of constituents from analyses of samples obtained in the local vicinity of a unit. If the concentrations of potentially dangerous constituents are not above the local background threshold, the TSD unit would be considered clean closed. Any necessary remediation beyond the TSD unit closure would be accomplished during cleanup of the past-practice operable unit in which the TSD unit is located.

\subsubsection{Health-Based Closure}

Health-based closure is closure of a TSD unit accomplished by treating or removing contamination to concentrations based on protection of human health and the environment. The situation for such closures occurs at the Hanford Site because of the past-practice operable units (CERCLA and RCRA) that surround the operating TSD units. The remediation of past-practice operable units is based on human health and environmental protection standards. The health-based levels will be based on equations and exposure assumptions presented in the Hanford Site Baseline Risk Assessment Methodology (DOE-RL 1992a). For noncarcinogens, the principal variable relating human health to action levels is the oral reference dose, and the oral reference dose is defined as the level of daily human exposure at or below which no adverse effect is expected to occur during a lifetime. For carcinogens, the 
cancer slope factor is the basis for determining human health effects; it is measurement of risk per unit dose. The oral reference dose and cancer slope factor are chemical specific and are obtained from the Integrated Risk Information System (IRIS) (EPA 1989a), a database that is updated periodically by the EPA. Health-based levels will be based on values that are current at the time of approval of closure documentation.

Protection of human health and the environment will be accomplished by removing or treating all contamination at a TSD unit to concentration levels that are not a threat to human health and the environment. However, remediation will not be below background levels, if these background levels are above health-based standards. Health based risk standards will be established using guidance such as WAC 173-340, the EPA Integrated Risk Information System database (EPA 1989a), the EPA Risk Assessment Guidance for Superfund: Human Health Evaluation Manual (EPA 1989c), the Hanford Site Baseline Risk Assessment Methodology (DOE-RL 1992a), and other appropriate information.

\subsubsection{Landfill Closure}

A landfill closure occurs when waste or contamination is left at the TSD unit in concentrations that are above health-based standards. When waste or contamination is left in place, the submittal of postclosure permit application documentation is required. This documentation would contain a RCRA-compliant landfill cover design and a postclosure monitoring plan. The postclosure monitoring plan would describe how the covered TSD unit would be monitored and maintained to ensure protection of human health and the environment. Regulations require monitoring and maintenance for at least 30 years unless a shorter time is approved by Ecology (the shorter time must be shown to be sufficient to protect human health and the environment).

\subsection{Closure PERFORMANCE STANDARDS}

The following sections address closure performance standards and waste removal and decontamination standards.

A11 plans will be developed to close TSD units in a manner that meets the following closure performance standards of WAC 173-303-610(2):

"(a)(i) Minimizes the need for further maintenance;

(ii) Controls, minimizes or eliminates to the extent necessary to protect human health and the environment, postclosure escape of dangerous waste, dangerous constituents, leachate, contaminated run-off, or dangerous waste decomposition products to the ground, surface water, ground water, or the atmosphere; and

(iii) Returns the land to the appearance and use of surrounding 1 and areas to the degree possible given the nature of the previous dangerous waste activity." 


\subsubsection{Minimizing the Need for Future Maintenance}

Minimizing the need for future maintenance will be accomplished by clean closing (at or below health-based standards) the specific TSD units whenever possible. Clean closure will eliminate the need for future maintenance. In cases where clean closure cannot be achieved, future maintenance needs will be addressed in unit-specific postclosure permit application documentation.

\subsubsection{Protection of Human Health and the Environment}

Protection of human health and the environment will be accomplished by removing or treating all contamination at a TSD unit to concentration levels that are not a threat to human health and the environment. If contamination cannot be removed or treated to levels that are protective of human health and the environment and must be left in place, a RCRA-compliant landfill cover will be installed. Regulations require monitoring and maintenance for at least 30 years unless a shorter time is approved by Ecology (the shorter time must be shown to be sufficient to protect human health and the environment).

Health based risk standards will be established using guidance such as WAC 173-340, the EPA Integrated Risk Information System database (EPA 1989a), the EPA Risk Assessment Guidance for Superfund: Human Health Evaluation Manual (EPA 1989C), the Hanford Site Baseline Risk Assessment Methodology (DOE-RL 1992a), and other appropriate information.

\subsubsection{Return Land to the Appearance and Use of Surrounding Land}

Closure plans will include, to the extent practicable, consideration of returning the TSD units to an appearance compatible with surrounding structures and/or the semi-desert terrain of the area.

\subsection{CLOSURE ACTIVITIES}

The activities undertaken to perform closure for an individual TSD unit for which final status is sought are identified in the unit-specific closure and postclosure plans. General closure activities address the following three aspects during the cleanup of the Hanford Site.

- Waste investigation

- Remediation process

- Sampling methods.

In addition to these aspects, the sampling methods and sample data reduction and inventory database control aspects are discussed in the following sections. 
DOE/RL-91-28, Rev. 1

$05 / 28 / 93$

1

2

3

4

5

6

7

8

9

10

11

12

13

14

15

16

17

18

19

20

21

22

23

24

25

26

27

28

29

30

31

32

33

34

35

36

37

38

39

40

41

42

43

44

45

46

47

48

49

50

\subsubsection{Waste Investigation}

During the waste investigations, the TSD unit-specific closure plans will ensure that the waste is characterized properly in terms of presence, location, concentration, and volume of each contaminant. Research of process records, drawings, and photographs will shape the initial sampling strategy.

As field information and laboratory results become available, the sampling strategy might specify more sampling until the waste contaminants can be reliably located and quantified. Information specific to any one TSD unit is included in the Unit-Specific Portion of this permit application.

\subsubsection{Remediation Process}

The remediation process for a TSD unit will be agreed upon with the appropriate regulatory agency(s) using one of the three closure options (clean, health-based, or landfi11; Sections 11.1.1, 11.1.2, and 11.1.3, respectively). The agreed upon closure option will include sampling to determine if clean closure is achievable unless landfill closure is selected. If some remediation is undertaken, the sampling results will be used to determine when the remediation effort has been completed. Information specific to any one TSD unit is included in the Unit-Specific Portion of this permit application.

\subsubsection{Sampling Methods}

Sampling will be accomplished according to information contained in established environmental regulations and guidelines using the data quality objectives process (EPA 1987). This information has been used in developing protocols set forth in contractor procedures and in SW-846. These protocols will be followed in obtaining and handling all samples. Field duplicate, equipment blank, and trip blank samples will be taken as appropriate and analyzed as a check on field sampling procedures, cross-contamination of samples, contamination from sample handling, and laboratory contamination. Samples usually will be taken on intervals down to 3 feet $(0.91$ meter) for non-land disposal units. For land disposal units, some vadose zone characterization wells might be required. Details on the number of samples, sample depth, and number of vadose zone wells needed are included in the UnitSpecific Portion of this permit application.

The analytical data obtained from the sampling of each TSD unit will be evaluated by SW-846 methods and analyzed by a cognizant person in the media involved (i.e., soil, water, concrete, or air). The resulting concentration levels of the identified constituents will be compared with the corresponding background level or health- and environmental-based standards. If this comparison supports the conclusion that the area does not contain greater contaminant concentrations than the background or health- and environmentalbased levels, the area will be considered decontaminated and can be cleaned closed. If sample results from a particular TSD unit do not meet the closure criteria, the particular constituents that exceed the action levels will be 
1 identified, and further evaluations of the potential success of additional

2 decontamination efforts will be limited to these constituents.

Sampling and analysis of materials that are not covered by SW-846 will be achieved using protocols, procedures, and methods approved by the appropriate regulatory agency(s) before conducting the sampling or analytical work. A description of procedures currently used to support closure activities, as well as the specific sampling plan, are included in the Unit-Specific Portion of this permit application.

\subsection{CLOSURE AND POSTCLOSURE PLAN}

The unit-specific closure and postclosure $p l a n$ is designed for closure of a TSD unit where closure will be implemented in the future once operations are discontinued. This closure and postclosure $p l a n$ will be implemented when approval is received from Ecology and the EPA and after the final waste receipt by the TSD unit.

\subsubsection{Closure Plan}

The closure $\mathrm{plan}$ contains information on closure performance standards, decontamination, waste inventory removal, sampling and analysis, schedule, and closure certification. Where possible, the closure plan will be prepared using clean closure as the basis for closing the TSD unit.

\subsubsection{Closure Schedule. In accordance with regulations, closure} activities will commence with the final receipt of waste. The TSD unitspecific schedule for closure will be provided in the closure plan. The activities to complete closure will be scheduled within 180 days unless a modified schedule is presented and agreed upon in the closure plan.

11.4.1.2 Extension for Closure Time. If closure activities will exceed the approved closure plan schedule, closure time extensions will be requested. All extension requests will include the justification for the extension and details for the remaining activities to achieve closure.

11.4.1.3 Amendments to Closure Plan. Should changes be required to the approved closure plan, an amended $\mathrm{plan}$ will be prepared and submitted to the proper regulatory agency(s) for approval in accordance with 40 CFR 264.112(c) and WAC $173-303-610(3)(b)$.

11.4.1.4 Certification of Closure. Within 60 days of final closure of any TSD unit, the DOE-RL will submit a certification of closure to the proper regulatory agency(s) in accordance with 40 CFR 264.115 and WAC 173-303-610(6). This certification will be signed by both the DOE-RL and by an independent professional engineer, and will state that the TSD unit has been closed in accordance with the approved closure plan. The certification will be submitted by registered mail or an equivalent delivery service. Documentation supporting the closure certification will be retained and will be furnished 
1. upon request to the proper regulatory agency(s). This documentation will be 2 maintained by the DOE-RL contact (or the successor) identified in

3 Section 11.10 .

11.4.1.5 Survey Plat. On submission of the closure certification for a disposal unit, a survey plat indicating the location and dimensions of the unit will be submitted to the following:

- Benton County Land Planning Department

- The EPA and Ecology.

The survey plat will be prepared and certified by a professional land surveyor. The plat will contain a note that states the DOE-RL's obligation to restrict disturbance of the TSD unit. This submission will satisfy the requirements of 40 CFR 264.119(a) and WAC 173-303-610(9).

11.4.1.6 Notice to Local Land Authorities. To the extent that residual contamination (waste left-in-place) exceeds limits for protection of human health and the environment, the local land authority (county-specific land zoning board and engineer) will be provided a certified legal description of the contaminant location and contaminant inventory.

\subsubsection{Postclosure Plan}

For landfill closure (closure with waste in place) of a TSD unit for which final status is sought, a postclosure plan will be submitted with the closure plan.

11.4.2.1 Inspection Plan. The inspection plan will describe inspections to be conducted during the postclosure period, the frequency of inspections, the inspection procedures, and the logs to be kept. The inspection plan will contain information on the following items, as applicable: security control devices; erosion damage; cover settlement, subsidence, and displacement; vegetative cover condition; integrity of run-on and run-off control measures; cover drainage system; gas venting system; well condition; and benchmark integrity.

11.4.2.2 Groundwater Monitoring Plan. The groundwater monitoring plan will describe activities associated with groundwater monitoring during the postclosure period. The groundwater monitoring plan will contain the following information, as applicable: interim status period groundwater monitoring data, aquifer identification, contaminant plume description, detection monitoring program, compliance monitoring program, and corrective action program.

11.4.2.3 Maintenance Plan. The maintenance plan will describe the preventative and corrective maintenance procedures, equipment, and material needs. The plan will contain the following information, as applicable: repair of security control devices; erosion damage repair; correction of settlement, subsidence, and displacement; mowing, fertilization, and other 
vegetative cover maintenance; repair of run-on and run-off control structures; and well replacement.

11.4.2.4 Provisions to Amend Postclosure Plan. Should changes be required to approved postclosure plan documentation, amended documentation will be prepared and submitted to the proper regulatory agency(s) for approval in accordance with 40 CFR 264.112(c) and WAC 173-303-610(3)(b).

11.4.2.5 Certification of Completion of Postclosure Care. Within 60 days after completion of the established postclosure care period for each dangerous waste disposal unit, the DOE-RL will submit to Ecology, by registered mail, a certification that the postclosure care period for the unit was completed in accordance with the approved postclosure plan. This certification will be signed by a representative of the DOE-RL and by an independent registered professional engineer.

\subsection{POSTCLOSURE PERMIT APPLICATION DOCUMENTATION}

A TSD unit closed under interim status with waste in place (landfill closure) will be closed in accordance with WAC $173-303-650(6), 660(9), 680(4)$, and $665(6)$. The postclosure permit application documentation as required in the Tri-Party Agreement, Section 6.3.2, will be submitted separately from the closure and postclosure plan. Typicaliy, this documentation will be submitted formally following some amount of closure area sampling and when data indicate that some level of residual contamination above health-based standards will remain in place. Postclosure permit application documentation will include a discussion of the closure and postclosure plan, cover design, inspection plan, groundwater monitoring plan, and a maintenance plan.

\subsubsection{Provisions to Amend Postclosure Permit Application Documentation}

Should changes be required to approved postclosure permit application documentation, amended documentation will be prepared and submitted to the proper regulatory agency(s) for approval in accordance with 40 CFR 264.112(c) and WAC 173-303-610(3)(b).

\subsubsection{Certification of Completion of Postclosure Care}

Within 60 days after completion of the established postclosure care period for each dangerous waste disposal unit, the DOE-RL will submit to Ecology, by registered mail, a certification that the postclosure care period for the unit was completed in accordance with the approved postclosure permit application documentation. This certification will be signed by a representative of the DOE-RL and by an independent registered professional engineer. 


\subsection{NOTICE IN DEED}

For those TSD units that cannot be clean closed, the following action will be taken in accordance with 40 CFR 264.119 and WAC 173-303-610(1)(b). Within 60 days of the certification of closure, the DOE-RL will sign, notarize, and file for recording the notice indicated below. The notice will be sent to the Auditor of Benton County, P.0. Box 470, Prosser, Washington, with instructions to record this notice in the deed book.

\section{TO WHOM IT MAY CONCERN}

The United States Department of Energy, Richland Operations Office, an operations office of the United States Department of Energy, which is a department of the United States government, the undersigned, whose local address is the Federal Building, 825 Jadwin Avenue, Richland, Washington, hereby gives the following notice as required by 40 CFR 264.119 and WAC 173-303-610(10) (whichever is applicable):

(a) The United States of America is, and since April 1943, has been in possession in fee simple of the following described lands: (legal description of the TSD unit).

(b) The United States Department of Energy, Richland Operations office, by operation of the (name of TSD unit), has disposed of hazardous and/or dangerous waste under the terms of regulations promulgated by the United States Environmental Protection Agency and the Washington State Department of Ecology (whichever is applicable) at the above described land.

(c) The future use of the above described land is restricted under terms of 40 CFR 264.117 (c) and WAC 173-303-610(7)(d) (whichever is applicable).

(d) Any and all future purchasers of this land should inform themselves of the requirements of the regulations and ascertain the amount and nature of wastes disposed on the above described property.

(e) The United States Department of Energy, Richland Operations office, has filed a survey plat with the Benton County Planning Department and with the United States Environmental Protection Agency, Region 10, and the Washington State Department of Ecology (whichever are applicable) showing the location and dimensions of the (name of the TSD unit) and a record of the type, location, and quantity of waste treated. 


\section{$1 \quad 11.7$ CLOSURE COST ESTIMATES}

Federal facilities are not required to comply with WAC 173-303-620 as is stated in the regulations. However, the DOE-RL has agreed to provide projections of anticipated costs for closure of final status TSD units (i.e., those units which have been incorporated into the Hanford Facility Permit) annually in a separate report (Chapter 12.0). Submittal of this report will take place on October 30 of each year, starting with the year after the issuance of the initial Hanford Facility Permit.

\subsection{POSTCLOSURE COST ESTIMATES}

Federal facilities are not required to comply with WAC 173-303-620 as is stated in the regulations. However, the DOE-RL has agreed to provide projections of anticipated costs for postclosure for final status TSD units (i.e., those units which have been incorporated into the Hanford Facility Permit) annually in a separate report (Chapter 12.0). Submittal of this report will take place on October 30 of each year, starting with the year after the issuance of the initial Hanford Facility Permit.

\subsection{CLOSURE OF THE HANFORD FACILITY}

Final closure of the Hanford Facility will be achieved when closure activities for all TSD units have been completed, as specified in either closure and postclosure plan or postclosure permit application documentation. Completion of these activities will be documented using either certifications of closure, in accordance with WAC 173-303-610(6), or certifications of completion of postclosure care, in accordance with WAC 173-303-610(11).

\subsection{CLOSURE CONTACTS}

The following office (or its successor) is the official closure contact:

Office of Environmental Assurance, Permits, and Policy

U.S. Department of Energy

Richland Operations Office

P.0. Box 550

Richland, Washington 99352

(509) 376-5441. 
Remove or treat

$05 / 28 / 93$

dangerous waeto

inventory and visiblo

redidues.

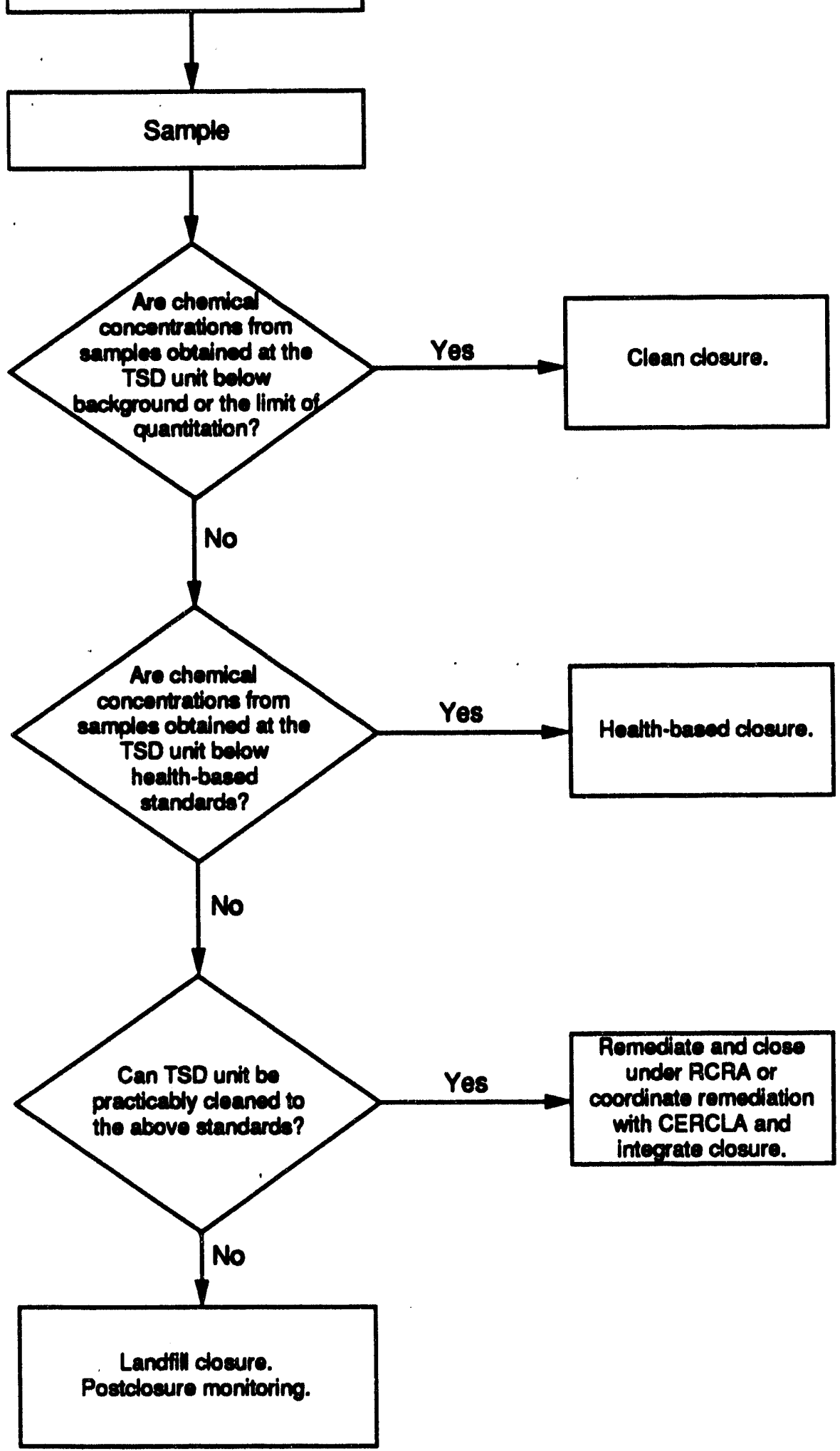

Figure 11-1. General Closure Logic Flow Chart. 
3

$$
4
$$

\section{CONTENTS}

12.0 REPORTING AND RECORDKEEPING . . . . . . . . . . . 12-1

12.1 NOTIFICATION OF DANGEROUS WASTE ACTIVITIES . . . . . . 12-1

12.2 TREATMENT, STORAGE, AND/OR DISPOSAL REQUIREMENTS . . . . . 12-1

12.2.1 Reports . . . . . . . . . . . . . . . . 12-2

12.2.1.1 Waste Manifest Reports ...... . . . 12-2

12.2.1.2 Annual Dangerous Waste Reports . . . . . 12-2

12.2.1.3 Biennial Hazardous Waste Reports . . . . 12-2

12.2.1.4 Groundwater Monitoring Reports . . . . . . 12-3

12.2.1.5 Contingency Plan Incident

Notifications .......... . 12-3

12.2.1.6 Closure Reports ........... 12-4

12.2.1.7 Postclosure Reports ........... 12-4

12.2.2 Recordkeeping Requirements . . . . . . . . . . 12-4

12.2.2.1 Permit Application Plans . . . . . . . 12-5

12.2.2.2 Operating Records . . . . . . . . . . 12-5

12.2.2.3 Miscellaneous Support Records . . . . . 12-7

12.3 IMMEDIATE REPORTING . . . . . . . . . . . . . 12-8

\section{TABLE}

12-1. Treatment, Storage, and/or Disposal Reports and Records . . . T12-1 
DOE/RL-91-28, Rev. 1

$05 / 28 / 93$

This page intentionally left blank. 
DOE/RL-91-28, Rev. 1 $05 / 28 / 93$

\subsection{REPORTING AND RECORDKEEPING}

This chapter summarizes the Hanford Facility reporting and recordkeeping requirements. Required reports and records can be located through the RCRA Compliance Support organization (RCRA Compliance Support) by calling (509) 372-2804. Reports and records applicable to the Hanford Facility are summarized in Table 12-1 and include:

- Notification of dangerous waste activities

- Permit application plans

- Operating reports and records

- Land disposal restriction records

- Waste manifest reports and records

- Groundwater monitoring reports and records

- Contingency plan incident reports and records

- Closure and postclosure reports and records

- Miscellaneous support reports and records.

Reports and records will be maintained in accordance with regulatory

requirements. Requirements, as applicable, are indicated in Table 12-1.

\subsection{NOTIFICATION OF DANGEROUS WASTE ACTIVITIES}

Regulations require that facilities involved in the generation or transportation of dangerous waste or the owner or operator of a TSD facility have a current EPA/State identification number. The Hanford Facility is a single RCRA facility operating under EPA/State Identification Number WA7890008967.

The Hanford Facility complies with the generator reporting and recordkeeping regulations. Hanford Facility waste generation records and required reports (e.g., annual reports) are compiled and issued as single records or reports for the entire Hanford Facility. The Hanford Facility does not transport dangerous waste offsite. Transporters having their own EPA/State identification numbers are used to transport dangerous waste generated by the Hanford Facility (nonradioactive dangerous waste) offsite.

The scope of this chapter is restricted to a discussion of TSD facility reporting and recordkeeping requirements.

\subsection{TREATMENT, STORAGE, AND/OR DISPOSAL REQUIREMENTS}

The Hanford Facility reporting and recordkeeping methods common to TSD units are discussed in this section. The records and reports described in this section can be located by contacting RCRA Compliance Support. 


\subsubsection{Reports}

This section discusses the reporting requirements of WAC 173-303 and several parts of Title 40 , Code of Federal Regulations relating to aspects of dangerous waste management. The following are included in the reporting requirements:

- Waste manifest reports

- Annual dangerous waste reports

- Biennial dangerous waste reports

- Groundwater monitoring reports

- Contingency plan incident notifications

- Closure reports

- Postclosure reports.

Additional details of these reports are provided in the following sections. Copies of these reports can be located by contacting RCRA Compliance Support.

12.2.1.1 Waste Manifest Reports. The Hanford Facility has methods in place for tracking offsite waste shipments using waste manifests. The waste manifest is the source of two possible reports, the manifest discrepancy report filed in accordance with WAC 173-303-370(4), and the unmanifested waste report filed in accordance with WAC 173-303-390(1). Records documenting offsite waste shipments are retained.and can be located by contacting RCRA Compliance Support.

12.2.1.2 Annual Dangerous Waste Reports. The state of Washington, pursuant to WAC 173-303-390, requires an overall annual report for each facility that holds an active EPA/State identification number. The report is due to.Ecology on March 1 of each year. The report contents for the Hanford Facility include the following:

- The EPA/State identification number

- Name and address of the Hanford Facility

- Calendar year covered by the report

- Sources of the waste stored on the Hanford Facility

- Description and quantity of the waste stored on the Hanford Facility

- TSO methods

- Certification statement signed by an authorized representative.

The report form and instructions in the "Waste Management Facility Annual Dangerous Waste Report-Form 5" are used for this report.

12.2.1.3 Biennial Hazardous Waste Reports. The EPA requires, pursuant to 40 CFR 264.75, that an overall report describing each hazardous waste facility activity be submitted on March 1 of each even-numbered year. Ecology has been extended administrative responsibilities for biennial reporting as required by 40 CFR 264.75. A specific biennial report is not prepared and submitted as reporting requirements are satisfied by submittal of the annual report to Ecology. 
12.2.1.4 Groundwater Monitoring Reports. Groundwater monitoring reports and plans are discussed in the Unit-Specific Portion of this permit application. Reports can be located by contacting RCRA Compliance Support.

12.2.1.5 Contingency Plan Incident Notifications. The building emergency director or coordinator, TSD unit line management, and the contractor's environmental protection organization are responsible for making notifications as per unit-specific building emergency plans and Chapter 7.0 of this portion of the permit application. Notifications of all emergency situations requiring contingency plan implementation are made as required by 40 CFR 264.56 and WAC 173-303-360.

If a Hanford Facility TSD unit stops operations in response to a fire, an explosion, or a release that could present a hazard to human health and the environment, the building emergency director or coordinator notifies the DOE-RL, via TSD unit line management, that the unit is operational and the emergency cleanup is complete.

The DOE-RL is responsible for three types of notifications: the incident assessment report, a 15-day report, and the TSD unit restart notification. Details of these notifications are provided in the following sections.

12:2.1.5.1 Incident Assessment Report. The Occurrence Notification Center (509-376-2900) immediately will notify affected county emergency management, Ecology, and the individual designated as the on-scene coordinator for the southeastern Washington area of the National Response Center (800-424-8802) if a fire, an explosion, or a release on the Hanford Facility could threaten human heaith and the environment outside the Hanford Facility.

The report will contain the following information:

- Name and telephone number of reporter

- Name and address of the Hanford Facility/TSD unit

- Time and type of incident

- Name and quantity of material(s) involved to the extent known

- Extent of injuries if any

- Possible hazards to human health and the environment outside the Hanford Facility.

12.2.1.5.2 15-Day Report. The DOE-RL will provide a written report to Ecology within 15 days of any incident that requires implementation of the contingency plan. This report will include the following information:

- Name, address, and telephone number of the owner or operator

- Name, address, and telephone number of the Hanford Facility/TSD unit 
- Date, time, and type of incident

- Name and quantity of material(s) involved

- Extent of injuries if any

- Assessment of actual or potential hazards to human health and the environment where this is applicable

- Estimated quantity and disposition of recovered material that resulted from the incident

- Cause of incident

- Description of corrective action taken to prevent recurrence of the incident.

12.2.1.5.3 Treatment, Storage, and/or Disposal Unit Restart Notification. If a TSD unit stops operations in response to a fire, an explosion, or a release that could present a hazard to human health and the environment, the DOE-RL will notify Ecology and the appropriate local authorities before operations are resumed in the affected area(s) of the TSD unit. The notification will indicate that cleanup procedures are complete and that emergency equipment is cleaned and fit for its intended use.

12.2.1.6 Closure Reports. Reports regarding the closure of Hanford Facility TSD unit for which final status is sought will be made in accordance with the requirements of 40 CFR 264.115 and .116 and WAC 173-303-610(6) and (9). These reports are discussed in Section 11.4 .1 and include the certification of closure, survey plat, and notice to local land authorities.

12.2.1.7 Postclosure Reports. Postclosure plans and reports required by 40 CFR 264.119 and .120 and WAC 173-303-610(9), (10), and (11) for disposal units include the inspection plan, groundwater monitoring plan, maintenance plan, notice in deed, and certification of completion of postclosure care. These plans and reports are discussed in Sections 11.4.2 and 11.6.

\subsubsection{Recordkeoping Requirements}

Records retained by the Hanford Facility include:

- Permit application plans

- Operating records

- Miscellaneous support records.

These records are described in the following sections. These items can be located by contacting RCRA Compliance Support.

For purposes of maintaining records designated for the "Hanford Facility", the 700 Area of the Hanford Site is considered to meet the intent of WAC 173-303 even though the 700 Area is not located within the Hanford 
1 Facility boundary. Because of the limitation of space, records may be

2 archived, as appropriate, at the Federal Records Center, 6125 Sand Point Way, 3 Seattle, Washington 98115, or other federal government archive centers in the 4 state of Washington. Records archived at government archive centers also can 5 be located by contacting RCRA Compliance Support.

12.2.2.1 Permit Application Plans. A current copy of the plans contained in this permit application that are incorporated into the Hanford Facility Permit will be maintained in the operating record.

12.2.2.2 Operating Records. Operating records maintained at the TSD unit can be located by contacting RCRA Compliance Support. These records include the following:

- Description and the quantity of each dangerous waste received and the method(s) and date(s) of treatment at the TSD unit in accordance with 40 CFR 264 Appendix I and WAC 173-303-380

- Location of each dangerous waste stored within a TSD unit and the quantity at each location

- Waste analyses results

- Inspection records

- Waste minimization certification

- Land disposal restriction records

- Groundwater monitoring records

- Contingency plan incident reports.

12.2.2.2.1 Waste Description and Quantity. A description and the quantity of each dangerous waste handled by a TSD unit are maintained in TSD unit records. Waste manifests and onsite waste tracking records, describing the types and quantities of waste, are maintained as part of the operating record.

12.2.2.2.2 Waste Location. The location of each dangerous or mixed waste and the quantity stored within a TSD unit are documented and maintained. Transfers are documented on onsite waste tracking records and provided to other Hanford Facility TSD units receiving the waste. Copies of these onsite waste tracking records are maintained and can be located by contacting RCRA Compliance Support.

12.2.2.2.3 Waste Analysis. Waste analys is and designation records for TSD units are generated and maintained, as appropriate, for the following: 
- Waste resulting from a spill or leak that cannot be identified

- Waste generated at the TSD unit during decontamination or maintenance activities if required.

As required, results of these analyses are provided to other TSD units subsequently receiving the waste for further treatment, storage, and/or disposal.

12.2.2.2.4 Inspection Records. Records of unit-specific inspections are maintained for a period of at least 5 years from the inspection date. These records can be located by contacting RCRA Compliance support. The records include the following:

- The date and time of inspection

- The inspector's printed name and handwritten signature

- Notations of observations

- The date and nature of any repairs or other remedial actions.

12.2.2.2.5 Waste Minimization Certification. Annually a certification by the DOE-RL that the Hanford Facility is in compliance with waste minimization requirements is entered into the operating record as required by 40. CFR 264.73(b)(9).

12.2.2.2.6 Land Disposal Restrictions Records. Records related to treatment and disposal of waste subject to land disposal prohibitions are maintained by the Hanford Facility as required by 40 CFR 264.73(b)(i0) and (12). Possible records include:

- Waste placed in land disposal units under an extension to the . effective date of any 1 and disposal restriction granted pursuant to 40 CFR 268.5

- Waste placed in land disposal units under a petition granted pursuant to 40 CFR 268.6

- The applicable notice and certification required by 40 CFR 268.7(a) or 40 CFR 268.7 (b)

- The demonstration and certification required by 40 CFR 268.8 , if applicable, for waste subject to land disposal prohibitions or restriction.

An onsite waste tracking system is in place to document the transfer of waste subject to land disposal restrictions. Land disposal restriction documentation can be located by contacting RCRA Compliance Support.

12.2.2.2.7 Groundwater Monitoring Records. Groundwater monitoring records, where applicable, are addressed in the Unit-Specific Portion of this permit application. 
12.2.2.2.8 Contingency Plan Incident Records. Records documenting the details of any incidents requiring the implementation of the contingency plan (Chapter 7.0) are maintained in the facility operating record as required by 40 CFR 264.73 and WAC 173-303-380. The contingency $p 1$ an incident records can be located by contacting RCRA Compliance Support. In addition to these records, occurrence reports are generated to document incidents. The occurrence report describes all incidents, including those that are judged too minor to require the implementation of the contingency plan but are identified as offnormal events, unusual occurrences, or emergencies. These records can be located by contacting RCRA Compliance Support.

12.2.2.3 Miscellaneous Support Records. Miscellaneous support records include the following:

- Training records

- Closure and postclosure cost estimates

- Certification records.

In addition, a rationale for the inapplicability of liability coverage documentation is provided.

12.2.2.3.1 Training Records. The name of each employee and the waste management position held are maintained by the TSD unit. Training records document that employees have received the training required for that position. Training records on current employees are kept until closure of the unit. Trainjing records on former employees are kept for 3 years from the date the employee last worked at the TSD unit. Training records are maintained by the contractors' organizations in accordance with the requirements of the Privacy Act. Presently, the training records of individual employees are available for inspection purposes through the Freedom of Information Act. The DOE-RL is seeking authorization through the U.S. Department of Energy-Headquarters to amend the systems notice under the Privacy Act to allow regulatory agencies 'routine use' access to training records under this act.

12.2.2.3.2 Closure and Postclosure Cost Estimates. In accordance with 40 CFR 264.140(c) and WAC 173-303, these estimates are not required for federal facilities. The Hanford Facility is a federally owned facility for which the federal government is an operator and these estimates are not applicable.

An annual report updating projections of anticipated closure and postclosure costs for final status TSD units (i.e., those units which have been incorporated into the Hanford Facility Permit) will be submitted to Ecology on October 30 of each year, starting with the year after the issuance of the Hanford Facility Permit.

12.2.2.3.3 Certification Records. Reports, data, and information requested or required in direct support of the Hanford Facility Permit will be certified as required in accordance with WAC-173-303-810(12) and (13) or 40 CFR Part 2 and 40 CFR 270.11 for Hazardous and Solid Waste Amendment provisions. Records of certification will be maintained as part of the operating record. 
12.2.2.3.4 Liability Coverage Documentation. In accordance with 40 CFR 264.140(c) and WAC 173-303, this documentation is not required for federal facilities. The Hanford Facility is a federally owned facility for which the federal government is an operator and this documentation is therefore not applicable.

\subsection{IMMEDIATE REPORTING}

The DOE-RL verbally will report to Ecology and the EPA any noncompliance with the Hanford Facility Permit that might endanger human health and the environment. Any such information will be reported to Ecology and EPA within 24 hours after the DOE-RL becomes aware of the circumstances of the noncompliance. The immediate verbal report will contain all the information needed to determine the nature and extent of any potential threat to human health and the environment. 
Table 12-1. Treatment, Storage, and/or Disposal Reports and Records.

\begin{tabular}{|c|c|}
\hline Records and/or Reports & Regulation \\
\hline \multicolumn{2}{|l|}{ Notification: } \\
\hline $\begin{array}{l}\text { Notification of dangerous waste } \\
\text { activities }\end{array}$ & WAC 173-303-290 \\
\hline \multicolumn{2}{|l|}{ Permit Application Plans: } \\
\hline Waste analysis plan & WAC $173-303-300$ \\
\hline Contingency plan and amendments & WAC 173-303-350 \\
\hline Training plan & WAC $173-303-330$ \\
\hline Closure and postclosure plan & WAC 173-303-610 \\
\hline Inspection plans & WAC $173-303-320$ \\
\hline \multicolumn{2}{|l|}{ Operating Reports and Records: } \\
\hline Waste description and quantity & $\begin{array}{l}\text { WAC 173-303-380 } \\
40 \text { CFR 264, Appendix I }\end{array}$ \\
\hline Waste location & WAC $173-303-380$ \\
\hline Waste analysis & WAC $173-303-300,-380$ \\
\hline Inspection records & WAC $173-303-320,-380$ \\
\hline Waste minimization certification & 40 CFR $264.73(\mathrm{~b})(9)$ \\
\hline Land Disposal Restriction Records: & $\begin{array}{l}\text { WAC } 173-303-140 \\
40 \text { CFR } 264.74(b)(10),(11)\end{array}$ \\
\hline Extension to an effective date & 40 CFR 268.5 \\
\hline Petition for a variance & 40 CFR 268.6 \\
\hline $\begin{array}{l}\text { Notice and certification of treatment } \\
\text { standards }\end{array}$ & 40 CFR $268.7(a)$ or $268.7(b)$ \\
\hline $\begin{array}{l}\text { Demonstration and certification for a } \\
\text { temporary extension to the effective date }\end{array}$ & 40 CFR 268.8 \\
\hline Waste Manifest Reports and Records: & WAC $173-303-370$ \\
\hline Onsite waste tracking records & NR* \\
\hline Manifests & WAC $173-303-370$ \\
\hline Manifest discrepancy & WAC $173-303-220,-370$ \\
\hline Unmanifested waste & WAC $173-303-390$ \\
\hline Groundwater Monitoring Reports and Records: & WAC $173-303-390,-645,-810$ \\
\hline Detection monitoring & WAC $173-303-645$ \\
\hline Statistically significant & WAC 173-303-645 \\
\hline Permit modification & WAC $173-303-610,-645$ \\
\hline $\begin{array}{l}\text { Variance justification or engineering } \\
\text { feasibility plan }\end{array}$ & WAC $173-303-645$ \\
\hline
\end{tabular}


Table 12-1. Treatment, Storage, and/or Disposal Reports and Records. (sheet 2 of 2)

\begin{tabular}{|c|c|}
\hline Records and/or Reports & Regulation \\
\hline Alternate demonstration & WAC 173-303-645 \\
\hline Compliance monitoring & WAC $173-303-645$ \\
\hline Corrective action & WAC $173-303-645$ \\
\hline $\begin{array}{l}\text { Contingency Plan Incident Reports and } \\
\text { Records: }\end{array}$ & $\begin{array}{l}\text { WAC } 173-303-360,-380 \\
40 \text { CFR } 264.56,274.73\end{array}$ \\
\hline Incident assessment report & WAC $173-303-360$ \\
\hline 15-day report & WAC $173-303-360$ \\
\hline TSD unit restart notification & WAC $173-303-360$ \\
\hline Closure Reports and Records: & $\begin{array}{l}\text { WAC } 173-303-610 \\
40 \text { CFR 264.115, .116 }\end{array}$ \\
\hline Certification of closure & WAC $173-303-610$ \\
\hline Survey plat & WAC $173-303-610$ \\
\hline Notice to local land authorities & WAC $173-303-610$ \\
\hline $\begin{array}{l}\text { Postclosure Reports and Records (where } \\
\text { applicable): }\end{array}$ & $\begin{array}{l}\text { WAC } 173-303-610 \\
40 \text { CFR 264.119, .120 }\end{array}$ \\
\hline Inspection plan & WAC $173-303-610$ \\
\hline Groundwater monitoring plan & WAC $173-303-610$ \\
\hline Maintenance plan & WAC $173-303-610$ \\
\hline Notice in deed & WAC $173-303-610$ \\
\hline $\begin{array}{l}\text { Certification of completion of } \\
\text { postclosure care }\end{array}$ & WAC $173-303-610$ \\
\hline Miscellaneous Support Reports and Records: & \\
\hline Annual dangerous waste report & WAC $173-303-060,-070,-390$ \\
\hline Training documentation & WAC $173-303-330$ \\
\hline Environmental investigation instructions & NR \\
\hline Listing of engineering change notices & NR \\
\hline Listing of equivalency reports & WAC 173-303-830 \\
\hline Certification records & $\begin{array}{l}\text { WAC } 173-303-810 \\
40 \text { CFR Part 2, } 270.11\end{array}$ \\
\hline Anticipated closure and postclosure costs & NR \\
\hline Solid waste management units report & NR \\
\hline
\end{tabular}

NR $=$ no requirement . 


\section{CONTENTS}

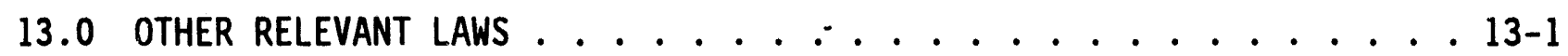

13.1 THE ATOMIC ENERGY ACT OF $1954 \ldots \ldots$. . . . . . . . . . . .

13.2 CLEAN AIR ACT OF $1977 \ldots \ldots \ldots$. . . . . . . . . . . . .

13.3 CLEAN WATER ACT OF $1977 \ldots \ldots$. . . . . . . . . . 13-2

13.4 COMPREHENSIVE ENVIRONMENTAL RESPONSE, COMPENSATION, AND LIABILITY ACT OF $1980 \ldots \ldots$. . . . . . . . . . . . . . . .

13.5 EMERGENCY PLANNING AND COMMUNITY RIGHT-TO-KNOW ACT OF $1986 \ldots \ldots \ldots$. . . . . . . . . . . . . . . . . .

13.6 ENDANGERED SPECIES ACT OF $1973 \ldots \ldots \ldots \ldots \ldots$. . . . . . . . .

13.7 FEDERAL INSECTICIDE, FUNGICIDE, AND RODENTICIDE ACT OF $1975 \ldots \ldots \ldots \ldots$. . . . . . . . . . . . . . . . .

13.8 FISH AND WILDLIFE COORDINATION ACT OF $1934 \ldots \ldots$. . . . . . .

13.9 HANFORD REACH STUDY ACT $\ldots \ldots \ldots$. . . . . . . . . . . . . .

13.10 NATIONAL ENVIRONMENTAL POLICY ACT OF $1969 \ldots \ldots$. . . . . . . .

13.11 NATIONAL HISTORIC PRESERVATION ACT OF $1966 \ldots \ldots$. . . . . . .

13.12 SAFE DRINKING WATER ACT OF $1974 \ldots \ldots \ldots \ldots$. . . . . . . . .

13.13 TOXIC SUBSTANCES CONTROL ACT OF $1976 \ldots \ldots \ldots \ldots$ 13-5

13.14 WILD AND SCENIC RIVERS ACT OF $1968 \ldots \ldots \ldots \ldots$ 13-5 
DOE/RL-91-28, Rev. 1

$05 / 28 / 93$

1

2

3

4

5

This page intentionally left blank. 
This chapter provides a summary of the regulatory review performed to determine that TSD units on the Hanford Facility have met, or will meet, their obligations with respect to other federal and state laws. The environmental laws evaluated include the following, all as amended:

- Atomic Energy Act of 1954

- Clean Air Act of 1977

- Clean Water Act of 1977

- Comprehensive Environmental Response, Compensation, and Liability Act of 1980

- Emergency Planning and Community Right to Know Act of 1986

- Endangered Species Act of 1973

- Federal Insecticide, Fungicide, and Rodenticide Act of 1975

- Fish and Wildlife Coordination Act of 1934

- Hanford Reach Study Act

- National Environmental Policy Act of 1969

- National Historic Preservation Act of 1966

- Safe Drinking Water Act of 1974

- Toxic Substances Control Act of 1976

- Wild and Scenic Rivers Act of 1968.

When other relevant laws apply to TSD units, best efforts will be made to obtain all other necessary permits and/or approvals in a timely fashion. For the purposes of this permit application, 'best efforts' means submittal of documentation and/or approval(s) in accordance with schedules specified in applicable regulations or as determined through negotiations with the applicable regulatory agency. All non-RCRA permits will be enforceable by the regulatory authority through which the permits are issued.

\subsection{THE ATOMIC ENERGY ACT OF 1954}

The Atomic Energy Act provides that the U.S. Atomic Energy Commission (succeeded by the U.S. Department of Energy for conducting nuclear defense, waste management, environmental restoration and remediation, and research and development activities at the Hanford Site) is authorized to develop and 
implement regulations to govern activities related to the design, location, and operation of U.S. Department of Energy sites, to protect health, and to minimize danger to life or property. The radioactive component of mixed waste is interpreted by the U.S. Department of Energy to be regulated under the Atomic Energy Act; the nonradioactive dangerous component of mixed waste is interpreted to be regulated under the RCRA and WAC 173-303.

The U.S. Department of Energy has issued several orders to govern the activities of its sites and to manage the health protection aspects of mixed waste. These orders provide for a consistent approach to managing waste that results from U.S. Department of Energy activities. The orders set radiation exposure limits and concentration guidelines to minimize exposure to radiation and detail the standards and procedures for managing mixed waste. All Hanford Facility operations are, and will be, carried out in accordance with these orders.

\subsection{CLEAN AIR ACT OF 1977}

The Clean Air Act establishes national ambient air quality standards and sets standards for abating air pollution and preventing further deterioration of air quality. Air standards are implemented and enforced primarily by state and local authorities. Applicable federal, state, and local requirements to control and abate air pollution include the following:

- National Emission Standards for Hazardous Air Pollutants (40 CFR 61) and National Emission Standard for Radionuclide Emissions from U.S. Department of Energy Faciiities (40 CFR 61, Subpart H)

- Air pollution control regulations (WAC 173-400 through 495) issued under the authority of the Washington Clean Air Act of 1967

- Radiation Protection - Air Emissions (WAC 246-247), which promulgates the policies set forth in Chapter 70.98 of the Revised Code of Washington, Nuclear Energy and Radiation, issued under the authority of the Washington Clean Air Act

- Benton-Franklin-Walla Walla Counties Air Pollution Control Authority, General Regulation 80-7 (1980).

\subsection{CLEAN WATER ACT OF 1977}

The Clean Water Act establishes national ambient water quality standards and sets standards for abating water pollution and preventing further deterioration of the water quality. These standards are implemented and enforced primarily by state and local authorities. Potentially applicable or relevant regulations relating to water pollution and water quality include the following: 
DOE/RL-91-28, Rev. 1

$05 / 28 / 93$

- National Pollutant Discharge Elimination System, 40 CFR 121 to 125

- Washington State Waste Discharge Permitting Program, WAC 173-216

- Water Quality Standards for Surface Waters of the State of Washington, WAC 173-201

- Water Quality Standards for Ground Waters of the State of Washington, WAC $173-200$

- On-Site Sewage System, WAC 246-272.

\subsection{COMPREHENSIVE ENVIRONMENTAL RESPONSE, COMPENSATION, AND LIABILITY ACT OF 1980}

The CERCLA, as amended in 1986 by the Superfund Amendments and Reauthorization Act (SARA), establ ishes a process for undertaking remedial action at inactive waste sites that contain hazardous substances, and establishes reporting requirements for releases of hazardous substances. The CERCLA remedial process has been initiated at the Hanford Site in response to identification on the National Priorities List. The Tri-Party Agreement addresses how RCRA corrective actions and CERCLA remedial actions are to be integrated $0_{i i}$ the Hanford Facility.

\subsection{EMERGENCY PLANNING AND COMMUNITY RIGHT-TO-KNOW ACT OF 1986}

- The Emergency Planning and Community Right-to-Know Act is a freestanding provision of the SARA. This act establishes the framework for state and local emergency planning and provides a mechanism for community awareness of hazardous chemicals present in a locality.

\subsection{ENDANGERED SPECIES ACT OF 1973}

The Endangered Species Act establishes a program for conserving endangered species and their ecosystems. Most activities on the Hanford Facility take place in areas that have been extensively developed during past construction. It is not expected that any listed or proposed endangered or threatened species or their habitats will be affected by Hanford Facility TSD unit activities. However, activities outside extensively developed areas will be reviewed for applicability and compliance. In the event that such species or habitats must be disturbed as a part of Hanford Facility operating or restoration and remediation activities, mitigative measures will be taken in accordance with applicable requirements.

\subsection{FEDERAL INSECTICIDE, FUNGICIDE, AND RODENTICIDE ACT OF 1975}

The Federal Insecticide, Fungicide, and Rodenticide Act estab? ishes a program to regulate the manufacture and use of pesticides. The use of all 
DOE/RL-91-28, Rev. 1

$05 / 28 / 93$

pesticides on the Hanford Facility is done in compliance with the Federal Insecticide, Fungicide, and Rodenticide Act.

\subsection{FISH AND WILDLIFE COORDINATION ACT OF 1934}

The Fish and Wildlife Coordination Act authorizes the U.S. Secretary of the Interior to assist and cooperate with public and private organizations to protect fish and wildlife. Activities at the Hanford Facility impacted by the Fish and Wildlife Coordination Act, such as the building or demolition of an outfall, will be handled in accordance with the agreement between the U.S. Department of Energy and the Washington State Department of Fisheries.

\subsection{HANFORD REACH STUDY ACT}

The Hanford Reach Study Act directs the Secretary of the Interior to prepare a study on the Hanford Reach of the Columbia River to consider the addition of the Hanford Reach to the National Wild and Scenic Rivers System. During the 8-year study period ending in 1996, activities undertaken from river miles 396 to 345 and within a quarter-mile of the Columbia River mean high-level mark must be conducted in consultation and coordination with the National Parks Service, acting for the Secretary of the Interior. Hanford Site activities undertaken within the Hanford Reach are conducted in compliance with the Hanford Reach Study Act.

\subsection{NATIONAL ENVIRONMENTAL POLICY ACT OF 1969}

The National Environmental Policy Act (NEPA) establishes a broad national policy for protection of environmental quality and provides the means for implementing that policy. All major construction and restoration and remediation projects at the Hanford Site are subject to the NEPA review process. As stated in the Tri-Party Agreement, the NEPA requirements are to ensure that the potential environmental impact of investigation and restoration and remediation activities is assessed. These assessments, when determined to be required, will be made primarily as part of the CERCLA remedial action and RCRA corrective action processes.

\subsection{NATIONAL HISTORIC PRESERVATION ACT OF 1966}

The National Historic Preservation Act establishes national policy to preserve historic places, which include sites, structures, and objects significant in American history, archeology, or culture. The Hanford Facility has in place requirements for the preservation of historical sites and cultural resources. During any future construction activity for a TSD unit, the site will be monitored for the presence of archaeological resources in accordance with regulations issued pursuant to, or other requirements of, the American Antiquities Preservation Act of 1906, the American Indian Religious Freedom Act of 1978; the Historic Sites, Buildings and Antiquities Act of 1935; and the Archaeological and Historic Preservation Act of 1979. 


\subsection{SAFE DRINKING WATER ACT OF 1974}

The Safe Drinking Water Act provides for protection of human health by setting standards for water supplied for public consumption and by protecting public drinking water sources. Drinking water systems at the Hanford Facility are in compliance with these standards.

\subsection{TOXIC SUBSTANCES CONTROL ACT OF 1976}

The Toxic Substances Control Act provides for protection of human health and the environment from exposure to certain hazardous and toxic chemical substances and mixtures. The Hanford Facility has in place a program for the cleanup, treatment, and disposal of materials regulated by the Toxic Substances Control Act.

\subsection{WILD AND SCENIC RIVERS ACT OF 1968}

The Hanford Facility does not affect any rivers presently designated under the Wild and Scenic Rivers Act. 
This page intentionally left blank. 
D0E/RL-91-28, Rev. 1 $05 / 28 / 93$

\section{CONTENTS}

2

3

$4 \quad 14.0$ CERTIFICATION $[K] \ldots \ldots \ldots \ldots \ldots$ 14-1 
DOE/RL-91-28, Rev. 1

$05 / 28 / 93$

This page intentionally left blank. 


\subsection{CERTIFICATION [K]}

The following certification, required by WAC 173-303-810(13), for all applications and reports submitted to Ecology is hereby included:

I certify under penalty of law that this document and all attachments were prepared under my direction or supervision in accordance with a system designed to assure that qualified personnel properly gather and evaluate the information submitted. Based on my inquiry of the person or persons who manage the system, or those persons directly responsible for gathering the information, the information submitted is, to the best of my knowledge and belief, true, accurate, and complete. I am aware that there are significant penalties for submitting false information, including the possibility of fine and imprisonment for knowing violations.

Richland Operations Office

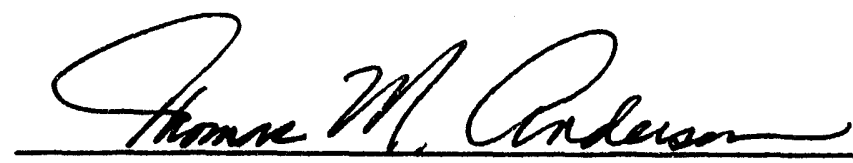

Co-operator*

Thomas M. Anderson, President Westinghouse Hanford Company

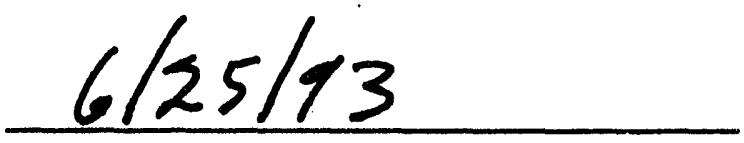

Date

* Westinghouse Hanford Company has responsibilities for the following treatment, storage, and/or disposal units on the Hanford Facility and is signing for the purpose of these units only: Double-Shell Tank System, 242-A Evaporator, Hanford Waste Vitrification Plant, Grout Treatment Facility, 204-AR Waste Unloading Station, Central Waste Complex, Waste Receiving and Processing, Low-Level Burial Grounds, Liquid Effluent Retention Facility, 200 Area Effluent Treatment Facility, T Plant Complex, B Plant, 241-Z Treatment and Storage Tanks, 222-S Laboratory Complex, 224-T Transuranic Waste Storage and Assay Facility, PUREX Storage Tunnels, Maintenance and Storage Facility, 616 Nonradioactive Dangerous Waste Storage Facility, and the 600 Area Purgewater Storage and Treatment Facility. 


\subsection{CERTIFICATION [K]}

The following certification, required by WAC 173-303-810(13), for all applications and reports submitted to Ecology is hereby included:

I certify under penalty of law that this document and all attachments were prepared under my direction or supervision in accordance with a system designed to assure that qualified personnel properly gather and evaluate the information submitted. Based on my inquiry of the person or persons who manage the system, or those persons directly responsible for gathering the information, the information submitted is, to the best of my knowledge and belief, true, accurate, and complete. I am aware that there are significant penalties for submitting false information, including the possibility of fine and imprisonment for knowing violations.

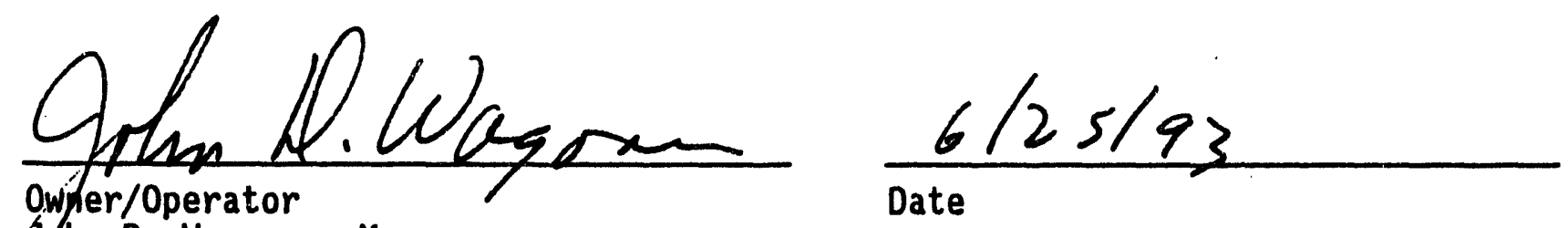

John D. Wagoner, Manager

W.S. Department of Energy

Richland Operations office

Co-operator*

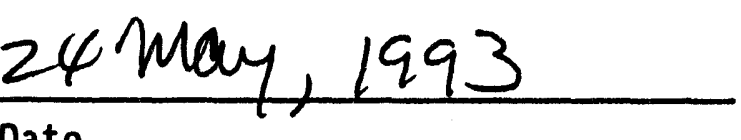

William R. Wiley, Director

Pacific Northwest Laboratory

* Pacific Northwest Laboratory has responsibilities for the following treatment, storage, and/or disposal units on the Hanford Facility and is signing for the purpose of these units only: 325/3100 Hazardous Waste Treatment Unit, Biological Treatment Test Facilities, Physical/Chemical Treatment Test Facilities, Thermal Treatment Test Facilities, and the 305-B Storage Unit. 


\section{CONTENTS}

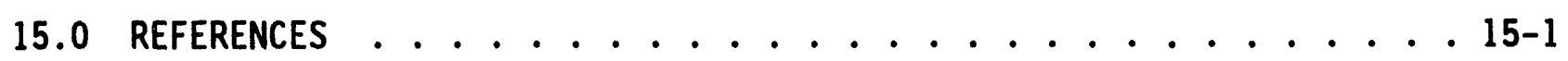

15.1 DOCUMENTS . . . . . . . . . . . . . . . 15-1

15.2 CODE OF FEDERAL REGULATIONS AND FEDERAL REGISTER . . . . 15-6 15.3 FEDERAL AND STATE ACTS . . . . . . . . . . . 15-7 15.4 WASHINGTON ADMINISTRATIVE CODE . . . . . . . . . 15-8

15.5 THE U.S. DEPARTMENT OF ENERGY ORDERS . . . . . . . . 15-8 
$G+\omega N \mapsto$

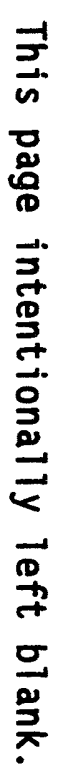

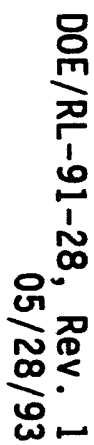




\subsection{REFERENCES}

\subsection{DOCUMENTS}

AASHTO, 1983, Standard Specification for Highway Bridges, AASHTO-HS 20-44, American Association of Highway and Transportation Officials, Washington, D.C.

ASTM, 1990, Annual Book of ASTM Standards, American Society for Testing and Materials, Philadelphia, Pennsylvania.

Barcelona, J.G., J.P. Gibb, J.A. Helfrich, E.E. Garske, 1985, Practical Guide for Ground-Water Sampling, EPA 600/2-85-104, Robert S. Kerr Environmental Research Laboratory, Ada, Oklahoma.

Benton-Franklin-Walla Walla Counties Air Pollution Control Authority, 1980, General Regulation 80-7.

COE, 1969, Columbia River Basin: Lower Columbia River Standard Project Flood and Probable Maximum Flood, Memorandum Report, U.S. Army Corps of Engineers, North Pacific Division, Portland, Oregon.

Cushing, C.E., ed., 1988, Hanford Site National Environmental Policy Act (NEPA) Characterization, PNL-6415, Pacific Northwest Laboratory, Richland, Washington.

DOE, 1987, Final Environmental Impact Statement, Disposal of Hanford Defense High-Level, Transuranic and Tank Wastes, DOE/EIS-0113, U.S. Department of Energy, Washington, D.C.

DOE, 1988, Site Characterization Plan, Reference Repository Location, Hanford Site, Washington, Consultation Draft, Vol. 1-9, DOE/RW-0164, Office of Civilian Radioactive Waste Management, U.S. Department of Energy, Washington, D.C.

DOE-RL, 1988a, Grout Treatment Facility Dangerous Waste Permit Application, DOE/RL-88-27, U.S. Department of Energy-Richland Operations Office, Richland, Washington.

DOE-RL, 1988b, Hanford Facility Dangerous Waste Part A Permit Application, DOE/RL-88-21, Vol. 1-3, as amended, U.S. Department of Energy-Richland Operations Office, Richland, Washington.

DOE-RL, 1988c, Hanford Site Waste Management Units Report, DOE/RL-88-30, Vols. 1-2, as amended, U.S. Department of Energy, Richland Operations Office, Richland, Washington.

DOE-RL, 1989a, Low-Level Burial Grounds Dangerous Waste Permit Application, DOE/RL-88-20, U.S. Department of Energy-Richland Operations Office, Richl and, Washington. 
DOE-RL, 1989b, Final Environmental Impact Statement - Decommissioning of Eight Surplus Production Reactors at the Hanford Site, Richland, Washington, DOE/EIS-0119, U.S. Department of Energy, Richland Operations Office, Richland, Washington.

DOE-RL, 1991a, Annual Report for RCRA Groundwater Monitoring Projects at Hanford Site Facilities for 1990, DOE/RL 91-03, U.S. Department of Energy-Richland Operations Office, Richland, Washington.

DOE-RL, 1991b, Liquid Effluent Retention Facility Dangerous Waste Permit Application, DOE/RL-90-43, U.S. Department of Energy-Richland Operations Office, Richland, Washington.

DOE-RL, 1992a, Hanford Site Baseline Risk Assessment Methodology, DOE/RL-91-45, U.S. Department of Energy, Richland Operations Office, Richland, Washington.

DOE-RL, 1992b, Hanford Site Groundwater Background, DOE/RL-92-23, U.S. Department of Energy, Richland Operations Office, Richland, Washington.

DOE-RL, 1992c, Hanford Site Soil Background, DOE/RL-92-24, U.S. Department of Energy, Richland Operations Office, Richland, Washington.

DOE-RL, 1993, Environmental Restoration and Waste Management Fiscal Year 1993 Site-Specific Plan of the Richland Field Office, Draft, DOE/RL-92-27, U.S. Department of Energy, Richland Operations Office, Richland, Washington.

Domenico, P.A. and G.A. Robbins, 1985, "A New Method of Contaminant Plume Analysis," Groundwater, Vol. 23, No. 4, pp. 476-485.

Ecology, 1986, Consent Agreement and Compliance Order, Ecology No. DE 86-133, PCHB No. 86-44, Washington State Department of Ecology, Olympia, Washington.

Ecology, 1987, State of Washington Part B Permit Application Requirements, Washington State Department of Ecology, Olympia, Washington.

Ecology, EPA, and DOE, 1992, Hanford Federal Facility Agreeinent and Consent Order, 2 vols., Washington State Department of Ecology,

U.S. Environmental Protection Agency, U.S. Department of Energy, Olympia, Washington.

EPA, 1986a, Permit Applicants' Guidance Manual for Exposure Information Requirements under RCRA Section 3019, Office of Solid Waste,

U.S. Environmental Protection Agency, Washington, D.C.

EPA, 1986b, Test Methods for the Evaluation of Solid Waste: Physical/Chemical Methods, SW-846, 3rd ed., U.S. Environmental Protection Agency, Washington, D.C. 
EPA, 1987, Data Quality Objectives for Remedial Response Activities, Development Process, EPA/540/87/003, U.S. Environmental Protection Agency, Washington, D.C.

EPA, 1989a, Integrated Risk Information System Database, Dialcom, U.S. Environmental Protection Agency, Silver Springs, Maryland, updated quarterly.

EPA, 1989b, Methods for Evaluating the Attainment of Cleanup Standards, Vol. 1: Soils \& Solid Media, \#230/02-89-042, U.S. Environmental Protection Agency, Office of Policy, Planning and Evaluation, Washington, D.C.

EPA, 1989c, Risk Assessment Guidance for Superfund: Human Health Evaluation Manual, Part A, Interim Final, U.S. Environmental Protection Agency, Washirgton, D.C.

EPA, 1989d, Statistical Analysis of Ground-Water Monitoring Data at RCRA Facilities, Interim Final Guidance, EPA/530-SW-89-026, U.S. Environmental Protection Agency, Washington, D.C.

EPA and Ecology, 1990, "Policy on Remediation of Existing Wells and Acceptance Criteria for RCRA and CERCLA", Letter dated 7/16/90, from T.L. Nord (Washington State Department of Ecology) and P.T. Day (EPA) to S.H. Wisness (DOE-RL).

ERDA, 1975, Final Environment Impact Statement - Waste Management Operations, ERDA-1538, U.S. Energy Research and Development Administration, Richland, Washington.

ERDA, 1976, Evaluation of Impact of Potential Flooding Criteria on the Hanford Project, RL0-76-4, U.S. Energy Research and Development AdministrationRichland Operations Office, Richland, Washington.

Evans, J.C., R.W. Bryce, D.J. Bates, and M.L. Kemner, 1990, Hanford Site Ground-Water Surveillance for 1989, PNL-7396, Pacific Northwest Laboratory, Richland, Washington, June.

FEMA, 1980, Flood Insurance Study: Benton County Washington, Federal Emergency Management Agency, Federal Insurance Administration, Washington, D.C.

Freeze, R.A. and J.A. Cherry, 1979, Groundwater, Prentice-Hall, Inc., Englewood Cliffs, New Jersey.

Freshley, M.D. and M.J. Graham, 1988, Estimation of Ground-Water Travel Time at the Hanford Site: Description, Past Work, and Future Needs, PNL-6328, Pacific Northwest Laboratory, Richland, Washington.

Graham, M.J., 1981, Hydrology of the Separations Area, RHO-ST-42, Rockwe 11 Hanford Operations, Richland, Washington. 
Graham, M.J., G.V. Last, and K.R. Fecht, 1984, An Assessment of Aquifer Intercommunication in the $B$ Pond-Gable Mountain Pond Area of the Hanford Site, RHO-RE-ST-12P, Rockwell Hanford Operations, Richland, Washington.

ICBO, 1991, "Earthquake Regulations," Uniform Building Code, UBC Section 2312, International Conference of Building Officials, Whittier, California.

Law, A.G., J.A. Serkowski, and A.L. Schatz, 1987, Results of the Separations Area Ground-Water Monitoring Network for 1986, RHO-RE-SR-87-24, Rockwell Hanford Operations, Richland, Washington.

Lyman, W.J., W.F. Reeh1, and D.H. Rosenblatt, 1982, Handbook of Chemical Property Estimation Methods, McGraw-Hill Book Company, New York, New York.

NFPA, 1989, National Fire Codes, National Fire Protection Association, Quincy, Massachusetts.

NIOSH, 1993, Pocket Guide to Chemical Hazards, National Institute of Occupational Safety and Health, U.S. Department of Health and Human Resources, Public Health Service, Centers for Disease Control, Washington, D.C. (updated quarterly).

PNL, 1989a, Procedures for Ground-Water Investigations, PNL-6984, Pacific Northwest Laboratory, Richland, Washington.

PNL, 1989b, RCRA Groundwater Monitoring Projects Quality Assurance Project Plan, QAPP-OHE-18, as amended, Pacific Northwest Laboratory, Richland, Washington.

PNL, 1990a, Archaeological Survey of the 200 East and 200 Wst Areas, Hanford Site, Washington, PNL-7264, Pacific Northwest Laboratory, Richland, Washington.

PNL, 1990b, Hanford Ground-Water Database Management Guide, PNL-MA-58i3, Pacific Northwest Laboratory, Richland, Washington.

PNL, 1992, Hanford Site National Environmental Policy Act (NEPA) Characterization, PNL-6415, Rev. 5, Pacific Northwest Laboratciry, Richland, Washington.

Skaggs, R.L. and W.H. Walters, 1981, Flood Risk Analysis of Cold Creek Near the Hanford Site, PNL-4219, Pacific Northwest Laboratory, Richland, Washington.

Smith, R.M. and W.R. Gorst, 1990, RCRA Ground-Water Monitoring Projects for Hanford Facilities: Annual Progress Report for 1989, PNL-7215, Pacific Northwest Laboratory, Richland, Washington.

Stone, W.A., J.M. Thorp, O.P. Gifford, and D.J. Hoitink, 1983, Climatological Summary for the Hanford Area, PNL-4622, Pacific Northwest Laboratory, Richland, Washingten. 
Tallman, A.M., K.R. Fecht, M.C. Marratt, and G.V. Last, 1979, Geology of the Separations Areas, Hanford Site, South-Central Washington, RHO-ST-23, Rockwell Hanford Operations, Richland, Washington.

WHC, 1988, Environmental Investigations and Site Characterization Manual, WHC-CM-7-7, Westinghouse Hanford Company, Richland, Washington.

WHC, 1989a, Interim-Status Ground-Water Monitoring Plan for the Grout Treatment Facility, WHC-SD-EN-AP-006, Rev. 0, Westinghouse Hanford Company, Richland, Washington.

WHC, 1989b, Operational Groundwater Monitoring at the Hanford Site -- 1988, WHC-EP-0260, Westinghouse Hanford Company, Richland, Washington.

WHC, 1989c, Revised Ground-Water Monitoring Plan for the 200 Areas Low-Leve 7 Burial Crounds, WHC-SD-EN-AP-015, Rev. 0, prepared by Pacific Northwest Laboratory for Westinghouse Hanford Company, Richland, Washington.

WHC, 1989d, Strategy for Handling and Disposing of Purgewater on the Hanford Site Washington, WHC-MR-0039, Westinghouse Hanford Company, Richland, Washington.

WHC, 1990a, Generic Specification Groundwater Monitoring Wells, WHC-S-014, Rev. 5, Westinghouse Hanford Company, Richland, Washington.

WHC, 1990b, Interim-Status Ground-Water Quality Assessment Program Plan for Waste Management Area 1 of the 200 Areas Low-Level Burial Grounds, WHC-SD-EN-AP-021, Westinghouse Hanford Company, Richland, Washington.

WHC, 1990c, Interim-Status Ground-Water Quality Assessment Program Plan for Waste Management Area 3 of the 200 Areas Low-Level Burial Grounds, WHC-SD-EN-AP-022, Westinghouse Hanford Company, Richland, Washington.

WHC, 1990d, Quality Assurance Project Plan for RCRA Groundwater Monitoring Activities, WHC-SD-EN-QAPP-001, as amended, Westinghouse Hanford Company, Richland, Washington.

WHC, 1991a, Geology and Hydrology of the Hanford Site: A Standardized Text for Use in Westinghouse Hanford Company Documents and Reports, WHC-SD-ER-TI-0003, Westinghouse Hanford Company, Richland, Washington.

WHC, 1991b, Ground Water Maps of the Hanford Site, December 1990, WHC-EP-0394-2, Westinghouse Hanford Company, Richland, Washington.

WHC, 1991c, Interim Status Ground-Water Monitoring Plan for the 200 East Area Liquid Effivent Retention Facility, WHC-SD-AP-024, Rev. 1, Westinghouse Hanford Company, Richland, Washington.

WHC, 1991d, Statistical Approach on RCRA Groundwater Monitoring Projects at the Hanford Site, WHC-SA-1124-FP, Westinghouse Hanford Company, Richland, Washington. 
WHC, 1993a, Hanford Well Rehabilitation, Remediation, and Decommissioning Plan, WHC-SD-EN-AP-122, Westinghouse Hanford Company, Richland, Washington.

WHC, 1993b, Tank Waste Remediation System Mission Analysis, WHC-EP-0627, Westinghouse Hanford Company, Richland, Washington.

WHC, 1993c, Westinghouse Hanford Company Operational Groundwater Status Report, WHC-EP-0595, Westinghouse Hanford Company, Richland, Washington.

Wilson, C.R., C.M. Einberger, J.S. Kindred, R.L. Jackson, and R.B. Mercer, 1991, Efficiency-Based Monitoring System Design, Energy in the Nineties Proceedings of a Specialty Conference sponsored by the Energy Division of the American Socisty of Civil Engineers, New York, New York.

\subsection{CODE OF FEDERAL REGULATIONS AND FEDERAL REGISTER}

10 CFR 40 , Domestic Licensing of Source Material.

40 CFR 61, National Emission Standards for Hazardous Air Pollutants.

40 CFR 121, State Certification of Activities Requiring A Federal License or Permit.

40 CFR 122, EPA Administered Permit Programs: The National Pollutant Discharge Elimination System.

40 CFR 123, State Program Requirements.

40 CFR 124, Procedures for Decisionmaking.

40 CFR 125, Criteria and Standards for the National Pollutant Discharge Elimination System.

40 CFR 264, Standards for Owners and Operators of Hazardous Waste Treatment, Storage, and Disposal Facilities.

40 CFR 265, Interim Status Standards for Owners and Operators of Hazardous Waste Treatment, Storage, and Disposal Facilities.

40 CFR 268, Land Disposal Restrictions.

40 CFR 270, EPA Administered Permit Programs: The Hazardous Waste Permit Program.

49 CFR 2:3, Track Safety Standards.

55 FR 145, "Requirement for Notification of Newly Identified Solid Waste Maragement Units", p. 30882, 40 CFR 270.30(1)(12)(A). 


\subsection{FEDERAL AND STATE ACTS}

American Antiquities Preservation Act of 1906, 16 USC 432.

American Indian Religious Freedom Act of 1978, 42 USC 1996.

Archaeological and Historic Preservation Act of 1960, 16 USC 469.

Atomic Energy Act of 1954, as amended, 42 USC 2011.

Clean Air Act of 1977, as amended, 42 USC 7401.

Clean Water Act of 1977, as amended, 33 USC 1251.

Comprehensive Environmental Response, Compensation, and Liability Act of 1980, as amended, 42 USC 9601 et seq.

Emergency Planning and Community Right-to-Know Act of 1986

Endangered Species Act of 1973, as amended, 16 USC 1531 et seq.

Federal Insecticide, Fungicide, and Rodenticide Act, 1975, as amended, 7 USC 136 et seq.

Fish and Wildlife Coordination Act of 1934, as amended, 16 USC 661.

Freedom of Information Act of 1966, as amended, 5 USC 552.

Hanford Reach Study Act, Public Law 100-605, November 4, 1988, 102 Stat. 3043.

Hazardous and Solid Waste Amendments of 1984, Public Law 98-616, 98 Stat. 3221, 42 USC 6912(a), 6921, 6922, 6924, 6925, 6926, 6930, 6935, $6937,6939,6991$, and 6993 .

Historic Sites, Buildings and Antiquities Act of 1935, 16 USC 461-467.

National Environmental Policy Act of 1969, 422 USC 4321 et seq.

National Historic Preservation Act of 1966, as amended, 16 USC 470 et seq.

Privacy Act of 1974, as amended, 5 USC 552a.

Resource Conservation and Recovery Act of 1976, as amended, 42 USC 6901 et seq.

Safe Drinking Water Act of 1974, as amended, 42 USC $300 \mathrm{f}$ et seq.

Shoreline Management Act of 1971, Revised Code of Washington, Chapter 90.58.010 et seq., Olympia, Washington.

State of Washington Hazardous Waste Management Act of 1976, as amended, Revised Code of Washington, Chapter 70.105, 01ympia, Washington. 
1

2

Superfund Amendment and Reauthorization Act of 1986, 42 USC 11001 et seq. Toxic Substances Control Act of 1976, 15 USC 2601 et seq. Washington Clean Air Act of 1967, Revised Code of Washington, Chapter 70.94, as amended, 01 ympia, Washington.

Wild and Scenic Rivers Act of 1968, as amended, 16 USC 1271.

\subsection{WASHINGTON ADMINISTRATIVE CODE}

WAC 173-200, Water Quality Standards for Ground-Waters of the State of Washington.

WAC 173-201, Water Quality Standards for Surface Waters of the State of Washington.

WAC 173-216, State Waste Discharge Permit Program.

WAC 173-218, Underground Injection Control Program.

WAC 173-303, Dangerous Waste Regulations.

WAC 173-340; Model Toxics Control Act Cleanup Regulation.

WAC 173-400 through 495, General Regulations for Air Pollution Sources.

WAC 197-11-960, State Environmental Policy Act Environmental Checklist.

WAC 246-247, Radiation Protection - Air Emissions.

WAC 246-272, On-Site Sewage Disposal.

\subsection{THE U.S. DEPARTMENT OF ENERGY ORDERS}

5000.3B, Occurrence Reporting and Processing of Operations Information. $5820.2 A$, Radioactive Waste Management. 6430.1A, General Design Criteria. 
DOE/RL-91-28, Rev. 1 $05 / 28 / 93$

\section{APPENDICES}

1 SOLID WASTE MANAGEMENT UNITS

5

6 IB GLOSSARY OF TECHNICAL TERMS

7

82 LOCATION MAPS

9
10

11 TA HANFORD FACILITY CONTINGENCY PLAN

13

14

15

16

17 
DDE/RL-91-28, Rev. 1

$05 / 28 / 93$

This page intentionally left blank. 
DOE/RL-91-28, Rev. 1

$05 / 28 / 93$

\section{A1.0 SOLID WASTE MANAGEMENT UNITS}

The requirement to address solid waste management units (SWMU) at a RCRA Facility was enacted as part of the Hazardous and Solid Waste Amendments of 1984 to RCRA [under Section 3004(u), "Continuing Releases At Permitted Facilities"]. Section $3004(u)$ states:

"Standards promulgated under this section shall require, and a permit issued after the date of enactment of the Hazardous and Solid Waste Amendments of 1984 by the administrator or a State shall require, corrective action for all releases of hazardous waste or constituents from any solid waste management unit at a treatment, storage, or disposal facility seeking a permit under this subtitle, regardless of the time at which waste was placed in such unit. Permits......."

Because this requirement is part of the 1984 Amendments, the EPA regulations for implementing Section 3004(u) currently are proposed under 40 CFR 264, Subpart S (264.501 through 264.560). The definition of a corrective action management unit and temporary unit were finalized on February 16, 1993. These definitions are promulgated at 40 CFR Part 264.552 and Part 264.553, respectively of 40 CFR Part 264, Subpart S.

\section{IA2.0 IDENTIFICATION OF SOLID WASTE MANAGEMENT UNITS}

Currently, over 1,300 waste management units have been identified within the Hanford Site, the majority of which are identified as SWMUs in accordance with the RCRA. As surveys and scoping studies are performed in support of the ongoing onsite cleanup program, additional SWMUs likely will be identified. The amount of information that currently exists for individual SWMUs varies significantly. It is intended that SWMUs be investigated in accordance with the past-practice process of the Tri-Party Agreement. In support of the issuance of a RCRA permit, the EPA conducted an initial RCRA Facility Assessment. Follow-on assessments, scoping studies, and investigations will be conducted in accordance with the Tri-Party Agreement, if necessary, to obtain additional information on currently identified SWMUs and newly identified SWMUs.

In support of the RCRA permitting of the Hanford Facility, all known SWMUs must be identified to include any releases of hazardous waste (or constituents) from these units. Because of the number and complexity of SWMUs on the Hanford Site, a realistic approach to the identification and documentation of SWMUs is needed. The proposed approach to satisfy the requirements for identifying and updating of SWMUs and releases from SWMUs uses a combination of the following:

- Hanford Waste Information Data System (WIDS)

- Hanford Site Waste Management Units Report (HSWMUR) (DOE-RL 1988d)

- Set of Hanford SWMU topographical maps. 
Because of the number of SWMUs and the age of some of these units, it is not feasible to provide all available drawings associated with these SWMUs. The existing maps contained in the HSWMUR will be used until maps more in 1 ine with regulatory requirements are developed.

\section{A2.1 WASTE INFORMATION DATA SYSTEM}

The Waste Information Data System (WIDS) is an electronic database that identifies known and reported SWMUs located within the DOE-RL controlled area (i.e., area on the Hanford Site over which DOE-RL has responsibility). The WIDS also includes other waste management units (i.e., non-SWMUs) in support of the overall cleanup mission of the Hanford Site. These include one-time spills, domestic sewage sites, and structures awaiting decontamination and decommissioning. The SWMUs are clearly designated from the non-SWMUs within the WIDS. The WIDS includes the type and location of the unit, when the unit was operated, general dimensions and description, and general descriptions of waste placed in the unit to include estimated quantities of radionuclides and chemicals contained in some units. As additional information on the SWMUs is made available, this information is entered into the WIDS. The WIDS will be used as the official listing of SWMUs for the DOE-RL controlled area. The EPA and Ecology have been provided with electronic access to the database.

As additional SWMUs are identified as a result of investigations and scoping studies conducted within the DOE-RL controlled area, the SWMUs will be entered into the WIDS, along with required information concerning the unit. $A$ special electronic file will be maintained within the WIDS system that identifies all SWMUs that have been entered into the system within the last 30 days. This will satisfy the requirement for notification of newly identified SWMUs. A second electronic file will be maintained to shown all previously entered SWMUs whose descriptive data have been modified within the last 30 days in accordance with Volume 55, Federal Register, Number 145, page 30882, Part 270.30(1)(12)(A). This file will be accessible upon request. Modifications will inc?ude newly discovered information concerning releases of hazardous materials from the SWMUs.

\section{A2.2 HANFORD SITE WASTE MANAGEMENT UNITS REPORT}

The HSWMUR is updated annually in accordance with Section 3.0 of the Tri-Party Agreement Action PIan. The HSWMUR provides summary information on each waste management unit contained within the WIDS. The annual update reflects all units added to the database during the preceding year, along with all updated information on all waste management units.

\section{A2.3 SET OF HANFORD SOLID WASTE MANAGEMENT UNITS TOPOGRAPHICAL MAPS}

The HSWMUR discussed previously includes a set of maps showing the location of all the SWMUs. These maps are currently not topographical in nature. Efforts are underway to develop a basemap for the Hanford Site. Because of the size of the Hanford Site and the number of SWMUs, it will take 


\begin{abstract}
time to survey and develop a complete set of topographical maps that meet the requirements of the regulations. As developed, these maps will replace the maps contained within the HSWMUR and will be updated annually along with the report. The existing maps are proposed to be used in Tieu of the topographical maps until the topographical maps are developed. The DOE-RL will negotiate the map requirements with the agencies as allowed in 40 CFR 70.14(b)(15) for large facilities on a case-by-case basis.
\end{abstract}

\title{
$1 A 2.4$ SCHEDULES OF COMPLIANCE
}

Schedules of compliance for the DOE-RL controlled area will be developed and maintained within the Tri-Party Agreement. All identified SWMUs have been assigned to operable units within the Tri-Party Agreement along with other waste management units. Newly identified SWMUs, when identified, will be assigned to the appropriate operable unit via the Tri-Party Agreement change control process. Either CERCLA response action authority or RCRA corrective action authority is assigned as the prime authority over the investigation and cleanup process for each operable unit. The schedules of compliance for those assigned RCRA corrective action authority are considered as part of the Hanford Facility Permit via reference to the Tri-Party Agreement. The Tri-Party Agreement change control process will be used to modify the schedules of compliance as necessary, meeting the intent of 40 CFR 270.34 (proposed). Remedy selections, either as a corrective measure or as an interim measure, will be incorporated into the Hanford Facility Permit as permit modifications.

The schedules of compliance will include any follow-on RCRA Facility Assessments that might be conducted, RCRA facility investigations, corrective measure studies, and corrective measure implementations. The schedules also will include any interim measures that are identified to be conducted. 
DOE/RL-91-28, Rev. 1

$05 / 28 / 93$

1
2
3
4
5

This page intentionally left blank. 


\section{DOE/RL-91-28, Rev. 1}

$05 / 28 / 93$

\section{APPENDIX 1B}

GLOSSARY OF TECHNICAL TERMS 
DOE/RL-91-28, Rev. 1

$05 / 28 / 93$

1

2

3

4

This page intentionally left blank. 


\section{APPENDIX 1B}

\section{GLOSSARY OF TECHNICAL TERMS}

Accuracy--Relates to the quality of the result, and is distinguished from precision that relates to the quality of the operation by which the result is obtained.

Advection--Transport of water or an aqueous property solely by mass motion. Analyte--The element, ion, or compound of interest.

ANOVA (Analysis of Variance)--Name given to variety of statistics procedures. All of these procedures compare the means of different groups of observations to determine whether there are any significant differences among the groups.

Anticlinal--Pertaining to an anticline.

Anticline--A fold, generally convex upward, whose core contains the stratigraphically older rocks.

Aquifer--A lithologic unit or combination of units that has appreciably greater water transmissibility than adjacent units. An aquifer stores and transmits water commonly recoverable in economic useable quantities.

Aquitard--A confining bed that retards but does not prevent the flow of water to or from an adjacent aquifer.

Assessment level monitoring--A program of monitoring groundwater under interim requirements. After a release of contaminants to groundwater has been determined, the rate of migration, extent of contamination, and hazardous constituent concentration gradients of the contamination must be identified.

Background--The composition of a medium that has not been effected by activities at a waste management unit.

Bar--A mass of sand, gravel or alluvium deposited on the bed of a stream, sea, or lake or at the mouth of a stream forming an obstruction to water navigation.

Basalt--A dark- to medium-dark-colored mafic (iron-magnesium rich) extrusive igneous rock with small grains composed primarily of feldspar (calcic plagioclase), pyroxene, with or without olivine, and varying proportions of glass.

Bottom zones--Refers to the base of basalt flows where aquifers can be found.

Byproduct material--"(a) For purposes of this part, the term "byproduct material" means any radioactive material (except special nuclear material) 
1 yielded in or made radioactive by exposure to the radiation incident to the 2 process of producing or utilizing special nuclear material.

3 (b) for purposes of determining the applicability of the Resource 4 Conservation and Recovery Act (42 U.S.C. 6901 et seq.) to any radioactive 5 waste substance owned or produced by the Department of Energy pursuant to the 6 exercise of its atomic energy research, development, testing and production

7 responsibilities under the Atomic Energy Act of 1954 (42 U.S.C. 2011 et seq.), 8 the words "any radioactive material," as used in paragraph (a) of this

9 section, refer only to the actual radionuclides dispersed or suspended in the substance will be subject to regulation under the Resource Conservation and Recovery Act." (10 CFR 962.3)

Carbonate--A compound containing the radical carbonate.

Cataclysmic--Any geologic event that produces sudden and extensive changes in the Earth's surface.

Channelways--Ancient or recent streams or river beds including flood zones.

Cobble--A rock fragment that ranges from 2.5 to 10 inches (64 to 256 millimeters) in diameter.

Compliance--Not exceeding regulations.

Confined aquifer--Groundwater bounded above and below by impermeable layers.

Conglomerate--Rounded water worn fragments of rock or pebbles, cemented together by another mineral substance. .

Conservative tracer--A tracer that does not chemically interact or degrade the aquifer system (i.e., the total quantity of the material in the solution remains constant).

Contaminant mobility--The capability of any physical, chemical or biological substance having an adverse effect on air, water, or soil and that can be transported readily by wind or water.

Control chart--Area graphical presentations of analytical data to determine if results are within desired limits.

Cross section--A profile or portraying of an interpretation of a vertical section of the earth explored by geophysical and or geological methods.

Detection--The lowest concentration by which an analyte can be detected on a field or laboratory instrument. Often recorded in parts per million or parts per billion.

Detrital--Pertaining to or formed by detritus material. 
DOE/RL-91-28, Rev. 1

$05 / 28 / 93$

1 Detritus--A collective term used for loose rock and mineral material that is 2 worn away by mechanical means, as by disintegration or abrasion (e.g.. sand, 3 silt. and clay).

Diffusion--The actual transport of mass, in the form of discrete atoms, through the lattice of a crystalline solid.

Discharge--The rate of flow at any given moment, expressed in volume per unit time (e.g., cubic meters/second).

Dispersivity--Ability of a contaminant to disperse within the groundwater by molecular diffusion and chemical mixing.

Distribution coefficient--The ratio of the concentration of a solute sorbed by ion exchange substances such as Earth materials, particularly clays, to the concentration of the solute remaining in solution. A large distribution coefficient implies that the substance is readily sorbed and is redissolved slowly. The concentration of material in the solid phase (i.e., rock or sediment) (moles per gram) divided by the concentration of material in the aqueous phase (moles per liter).

Domenico-Robbins--A two dimensional analytical transport model developed by Domenico and Robbins (1985).

Drinking Water Standard--Contaminant concentration specified in the Safe Drinking Water Act.

Drive-barrel--Heavy walled pipe used in impact drilling. Soil and rock are driven into a pipe connected to a cable as it is dropped rapidly on to the ground. The soil or rock is then extracted by striking the pipe.

Driving force--The hydraulic head that causes water to flow in one direction on another.

Effective porosity--The ratio of the volume of the void spaces of a soil mass that can be drained by gravity to the total volume of the mass of the soil.

Eolian--(a) Pertaining to the wind; especially said of such deposits as loess and dune sand, of sedimentary structures such as wind formed ripple marks, or of erosion and deposition accomplished by the wind. (b) Said of the active phase of a dune cycle, marked by diminished vegetal control and increased dune growth.

Epiclastic--A term applied to mechanically deposited sediments (e.g., mud, gravel, sand) consisting of weathered products of older rocks. A rock formed at the Earth's surface by consolidation of fragments of pre-existing rocks.

Epoch--A division of geologic time that identifies an abrupt change in the environment. 
1 Erosional windows--Can be considered a window to the past where portions of the land surface have been eroded away exposing landforms that represent the past.

Evapotranspiration--The sum total of that portion of precipitation that is returned to the atmosphere through evaporation and the transpiration of plants.

Facies--Part of a rock body as differentiated from other parts by appearance or composition and hat reflects the environment in which it was formed.

Fanglomerate--A fanglomerate is composed of heterogenous material that was originally deposited in an alluvial fan or delta as loose unconsolidated detrital material and has since become cemented into rock.

Fixed limits--A constant compliance limit or a fixed standard such as maximum concentration limit or assessment level monitoring.

Flow tops--Pertaining to the highest portion of individual basalt flows.

Fluvial-lacustrine--Said of those deposits formed by the streams flowing from lakes.

Formation(s)--Something naturally formed, commonly differing from adjacent rocks or soils. Most formations possess certain distinctive or repetitive combinations of distinctive rock types.

Geophysical--Pertaining to that science that deals with the exploration or prospecting of the earth using instruments and applying the methods of physics and engineering by observation of magnetic, seismic, electrical, and thermal distribution.

Glaciofluvial--Pertaining to streams flowing from glaciers or to the deposits made from these streams. In the Hanford Site area, this pertains to the deposited sands and gravels that were deposited because of the Lake Missoula flood

Granule--A rock fragment larger than a very coarse sand grain and smaller than a pebble. The fragment ranges in size from 0.08 to 0.16 inches $(2$ to 4 millimeters).

Gravels--An accumulation of water worn pebbles. Consists of rock grains or fragments that range in size from 0.19 to 3 inches (4.76 to 76 millimeters).

Groundwater mounds--A mound shaped elevation in a wacer table that builds up as a result of the downward percolation of water through the zone of aeration.

Hard-tool--Drill bit used in cable tool drilling to crush rock. The slurry created by the bit is retrieved and examined.

51 Henry's Law--The weight of a gas dissolved by a liquid is proportional to the 52 pressure of the gas. 
1 High energy--Refers to the environment of sediment deposition where the stream 2 or river flow or wave action is of sufficient quantity to carry significant 3 amounts of suspended soil and rock particles.

High-activity waste--High- and low-activity is reflective of the relative concentration of radionuclides in mixed waste.

High-level waste--Highly radioactive waste material that results from the reprocessing of spent nuclear fuel, including liquid waste produced directly in reprocessing and any solid waste derived from the liquid that contains a combination of transuranic waste and fission products in concentrations requiring permanent isolation.

Holocene--Recent. That period in time (epoch) since the last ice age in North America; also those sediment deposited during that epoch.

Hydraulic head--The height of the free surface of a body of water above a given subsurface point.

Hydraulic conductivity--The ratio of the groundwater flow velocity to the driving force for fluid flow through porous medium under saturated conditions.

Hydraulic gradient--As applied to an aquifer, the rate of change of the hydraulic head per unit of distance at a given point and direction.

Hydrogeology--A term used interchangeably with geohydrology referring to the hydrologic or flow characteristics of groundwater.

Hydrologic properties--Properties of a rock related to the capacity to transmit, hold, and deliver water.

Indicator--A geologic or other feature that suggests the presence of a geochemical anomaly inherent to the local geologic setting.

Indurated--The consolidation of a rock or soil hardened by heat, pressure, or cementation.

Infiltration--The flow of fluid (water) into a solid substance through pores or small openings.

Intercalated--Said of a relatively thin layer of soil or rock material that alternates with thicker layers of some other kind of soil or rock.

Intermittent--Periodic. Stopping and starting again in intervals.

Interval--The vertical difference between soil or rock bodies of differing origin or composition.

Loess--A homogeneous, nonstratified (nonlayered) unindurated soil consisting predominantly of silt of eolian (windblown) deposition. Often referred to as 'Palouse Soil' located in the far central southeastern portion of Washington 52 state. 


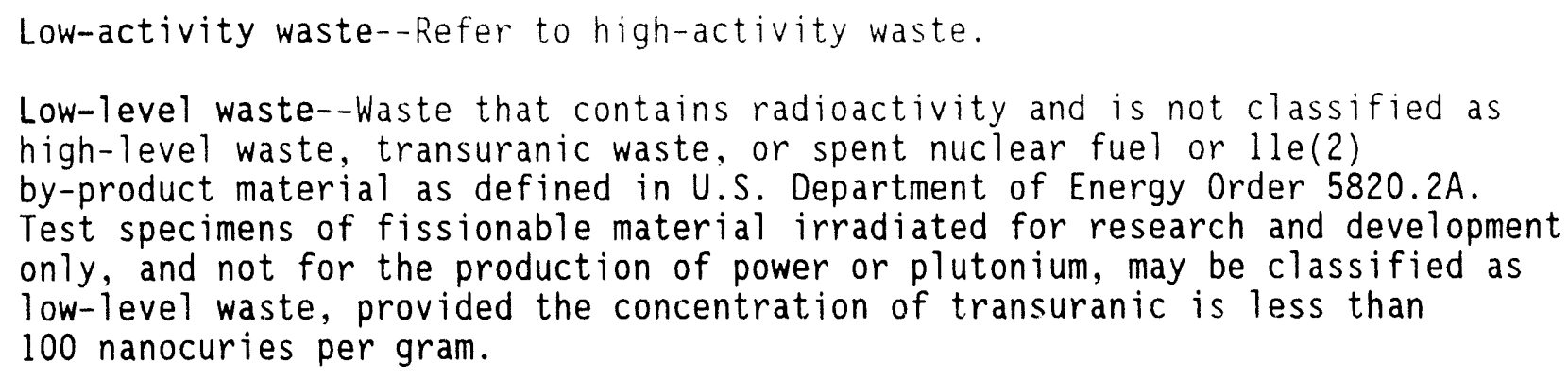

Maximum concentration limit--Contaminant concentration specified in the Safe Drinking Water Act.

Miocene--The fourth of the five epochs of which the Tertiary period is divided. The Miocene lasted from between 24 million years ago to 1.8 million years ago. Also those sediments that were deposited during that epoch.

Mixed waste--Waste that contains both hazardous and dangerous waste subject to RCRA, as amended, and the Ecology Dangerous Waste Regulations, and radioactive waste subject to the Atomic Energy Act.

Mode1--A working hypothesis or precise simulation, by means of description, statistical data, or analogy of a phenomenon or process that cannot be observed directly or that is difficult to observe directly.

Monocline--A steplike bend (flexure) in otherwise flatlying layers or beds of rock.

Operable unit--A group of contiguous past-practice waste sites related by site characteristics or operations so as to be considered collectively for purposes of environmental restoration under the CERCLA process.

Paleosols--A buried soil of the ancient past.

Palouse soil--Refer to loess.

Parameter--In statistics, a numerical quantity (such as the mean) that characterizes the distribution of a random variable or a population.

Permeability--The property or capacity of a porous rock, sediment, or soil for transmitting a fluid (e.g., groundwater).

Permeameter--An instrument for measuring permeability.

Perennial--Streams that flow throughout the year from source to mouth.

pH-- The negative logarithm of the hydrogen-ion activity in a solution, a measure of the acidity or basicity of a solution.

Physiography--The study of the genesis and evolution of 1 and forms. 
1 Pleistocene--The earliest of the two epochs comprising the Quaternary period.

2 The Pleistocene lasted from between 1.8 mi?lion years ago to 10.000 years ago.

3 Also, those sediments that were deposited during that epoch.

4

Porosity--The percentage of the bulk volume of a rock or soil that is occupied by interstices or voids.

Potentiometric--Surface to which water in an aquifer would rise by hydrostatic pressure or head.

Practical quantification limits--The lowest level that can be reliably achieved within specified limits of precision and accuracy during routine laboratory operating conditions.

Pre-Missoula--As pertaining to before the time of the flooding caused by the breaching of ice dams that contained Lake Missoula in northwest Montana.

Precision--The degree of agreement or uniformity of repeated measurements of a quantity; the degree of refinement. Refer to accuracy.

Prediction interval--In a regression analysis, a value or set of values for which one can assert with given probability that they will contain a future observation.

Purgewater--Water being evaavated from wells or from wells that are undergoing aquifer testing.

Quartzose--Containing quartz as the principal constituent.

Recharging--The quantity of water that is added to the zone of saturation or the aquifer. Intake.

Recovery phase--The time an aquifer requires to reach equilibrium after pumping, such as in a slug test.

Sand--Detrital material varying in diameter from very fine grained $[0.002$ to 0.005 inch $(0.0625$ to 0.125 millimeter $)]$ to very coarse grained $[0.07$ inch (2 millimeter)].

Sandy--A rock or soil in which one of the constituents is sand. Refer to sand.

Sediment--(a) (geological) Solid fragmental material that originates from weathering of rocks and is transported by air, water, or ice, or that accumulates by other natural agents, such as chemical precipitation from solution or secretion by organisms; and that forms in layers on the Earth's surfaces at ordinary temperatures in a loose unconsolidated form; e.g., sand, gravel, silt, mud, till, loess, alluvium. (b) Strictly solid material that has settled from a state of suspension in a liquid, e.g., material at the bottom of an open body of water, such as a pond or an estuary. In the singular, the term usually is applied to material held in suspension in water 
or recently deposited from suspension. In the plural, the term is applied to all kinds of deposits, and refers to essentially unconsolidated materials.

Seismic--Pertaining to an earthquake or earth vibration.

Silt--A soil particle that ranges in size from 0.0002 to 0.002 inch $(0.0039$ to 0.0625 millimeter) in diameter.

Silty--A rock or soil in which one of the constituents is silt. Refer to silt.

Slope wash--Soil and rock material that is being or has been moved down slope predominantly by the action of gravity assisted by running water that is not concentrated into channels.

Slope--The inclined surface of hill, mountain, plateau, plain, or any other part of the Earth's surface.

Slug testing--A single well test to determine the insitu hydraulic conductivity of an aquifer by the instantaneous addition or removal of a known quantity (slug) of water into or from a well, and the subsequent measurement of the resulting well recovery time.

Source material--"(1) uranium, thorium, or any other material which is determined by the Commission pursuant to the provisions of section 61 [42 U.S.C. 2091] to be source material; or (2) ores containing one or more of the foregoing materials, in such concentration as the Commission may by regulation determine from time to time." (Atomic Energy Act of 1954)

Special nuclear material--"(1) plutonium, uranium enriched in the isotope 233 or in the isotope 235, and any other material which the Commission, pursuant to the provisions of section 51 [42 U.S.C. 2071], determines to be special nuclear material, but does not include source material; or (2) any material artificially enriched by any of the foregoing, but does not include source material." (Atomic Energy Act of 1954)

Specific conductance--A measure of the electrical conductivity of a liquid.

Stratigraphic-- Said of a stratum by which an arbitrary but systematic arrangement, zonation, or partitioning of a sequence of rock layers, of the Earth's crust, into units with reference to any or all of the attributes, properties, or characteristics that strata possess.

Structural--Pertaining to, part of, or consequent upon geologic structures.

Structures (tectonic)--Of, pertaining to, or designating rock structure and deformations as a result of forces caused by land movement and earthquakes.

Suprabasalt--Those sediments that are found above basalt flows.

Syncline--A fold, generally upward concaving, whose core contains the stratigraphically youngest rock. 
1 Temperature--Degree of hotness or coldness of a body or environment.

Tolerance--A permissible deviation from a specified value, expressed in actual values or more often as a percentage of the nominal value.

Topography--The general configuration of a land surface or any part of the Earth's surface, including its relief and its natural and man made features.

Transmissive zone--Pertaining to transmissivity. The zone where intercommunication is possible between differing aquifers.

Transmissivity--The rate (flow) at which water is transmitted through a unit width of aquifer.

Transuranic waste--Without regard to source or form, waste that is contaminated with alpha-emitting transuranium radionuclides with half-lives greater than 20 years and concentrations greater than 100 nanocuries per gram at the time of assay. At the Hanford Site, transuranic waste also includes uranium-233 and radium sources.

Travel time--The period of time necessary for a dangerous waste constituent released to the soil to enter any onsite or offsite aquifer or water supply system.

Tuff--A general term for all consolidated volcanic fragments.

Turbidity--The state, condition, or quality of opaqueness or reduced clarity of a fluid, due to the presence of suspended matter.

Vadose zone--Zone of aeration. A subsurface zone containing water under pressure less than that of the atmosphere, including water held by capillarity; and containing air or gases generally under atmospheric pressure. This zone is limited above by the land surface and below by the surface of the 'zone of saturation', i.e., the water table.

Vapor pressure--The pressure at which a liquid and its vapor are at equilibrium at a given temperature.

Velocity--The time rate of motion in a given direction (meter/second).

Veneer--A thin but extensive layer of sediments covering an older geologic layer or stratum.

Volcanic--of, pertaining to, like, or characterized by or composed of material originating from volcanoes or fissures.

Volcaniclastic--Pertaining to clastic or fragmental rock material containing volcanic material in whatever proportion, and without regard to its origin or environment.

Water table--The upper surface of a saturation zone except where that surface is formed by an impermeable layer. 
Yakima Fold Belt--Fold belt characterized by long, narrow anticlines and broad synclines extending generally eastward from the Cascade Range to the approximate center of the Columbia Plateau.

Sources:

10 CFR 962, Byproduct Material.

Atomic Energy Act of 1954, 42 USC 2011 et seq.

Bates, R.L., 1990, "Glossary of Geology", J.A. Jackson, ed., American Geological Institute, Falls Church, Virginia.

Basalt Waste I solation Project Glossary, SD-BWI-PMP-005, Rockwell Hanford Operations, Richland, Washington.

Dictionary of Geological Terms, Anchor Books Edition: 1976, Anchor Press/Doubleday, Garden City, New York.

A Dictionary of Mining, Mineral and Related Terms, 1968, U.S. Department of the Interior, U.S. Printing Office, Washington D.C.

Ecology, EPA, and DOE, 1992, Hanford Federal Facility Agreement and Consent Order, 2 vols., Washington State Department of Ecology,

U.S. Environmental Protection Agency, U.S. Department of Energy, 01 ympia, Washington.

EPA, 1989, Statistical Analysis of Ground-Water Monitoring Data at RCRA Facilities, Interim Final Guidance, PB89-15047, U.S. Environmental Protection Agency, Washington, D.C.

Freeze, R.A. and J.A. Cherry, 1979, Groundwater, Prentice-Hill Inc., Englewood Cliffs, New Jersey.

King, J.J., 1989, The Environmental Dictionary, Executive Enterprises, New York, New York.

Lee, C.C., 1989, Environmental Engineering Dictionary, Government Institutes Inc., Rockville, Maryland.

RCRA Groundwater Monitoring Technical Enforcement Guidance Document, 1986, National Water Well Association, Dublin, Ohio.

Myers, C.W./S.M. Price, and J.A. Caggiano, M.P. Cochran, W.J. Czimer, N.J. Davidson, R.C. Edwards, K.R. Fecht, G.E. Holmes, M.G. Jones, J.R. Kunk, R.D. Landon, R.K. Ledgerwood, J.T. Lillie, P.E. Long, T.H. Mitche11, E.H. Price, S.P. Reidel, and A.M. Tallman, 1979, Geologic Studies of the Columbia Plateau, A Status Report, RHO-BWI-ST-4, Rockwell Hanford Operations, Richland, Washington.

U.S. Department of Energy Order 5820.2A, Radioactive Waste Management. 
$\mathrm{DOE} / \mathrm{RL}-91-28$, Rev. 1

$05 / 28 / 93$

1 WAC 173-303, Dangerous Waste Regulations, Washington State Department of 2 Ecology, 0lympia, Washington.

3

4 Webster's New Riverside University Dictionary, 1984, Houghton Mifflin Company, 5 Boston, MA. 
DOE/RL-91-28, Rev. 1

$05 / 28 / 93$

\section{APPENDIX 2A}

LOCATION MAPS

$930528.1004 a j$

APP $2 A-i$

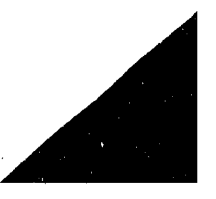


DOE/RL-91-28, Rev. 1

$05 / 28 / 93$

\section{APPENDIX 2A}

\section{CONTENTS}

\section{H-6-958 General Overview of Hanford Site.}

The Operable Unit maps are included for the purpose of locating TSD units for which final status is sought. Other localities on these maps are considered to be provided for purposes of 'information only'.

\begin{tabular}{|c|c|c|c|}
\hline Unit & Area & Class & Operable unit \\
\hline Double-Shell Tank System & 200EW & TS & $\begin{array}{l}200-P O-3 \\
200-P O-4 \\
200-1 U-6 \\
200-T P-5 \\
200-B P-7 \\
200-U P-3 \\
200-R O-2\end{array}$ \\
\hline 242-A Evaporator & $200 E$ & $T$ & $200-P 0-3$ \\
\hline Hanford Waste Vitrification Plant & $200 \mathrm{E}$ & TS & $200-B P-9$ \\
\hline Grout Treatment Facility & $200 E$ & TSD & $200-P 0-3$ \\
\hline 204-AR Waste Unloading Station & $200 \mathrm{E}$ & $\mathrm{T}$ & $200-\mathrm{PO}-3$ \\
\hline Central Waste Complex & $200 \mathrm{~W}$ & TS & $200-2 p-3$ \\
\hline Waste Receiving and Processing & $200 \mathrm{~W}$ & $\mathrm{~T}$ & $200-2 P-3$ \\
\hline Low-Level Burial Grounds & 200EW & D & $\begin{array}{l}200-B P-10 \\
200-P O-6 \\
200-2 P-3\end{array}$ \\
\hline Liquid Effluent Retention Facility & $200 E$ & $\mathbf{s}$ & $200-B P-11$ \\
\hline 200 Area Effluent Treatment facility & $200 \mathrm{E}$ & $T$ & $200-B P-11$ \\
\hline T Plant Complex & $200 \mathrm{~W}$ & $T$ & $200-T P-4$ \\
\hline B Plant & $200 E$ & TS & $200-B P-6$ \\
\hline $241-2$ Treatment and Storage Tanks & $200 \mathrm{~W}$ & TS & $200-2 P-1$ \\
\hline 222-s Laboratory Complex & $200 \mathrm{~W}$ & TS & $200-R O-3$ \\
\hline 224-T Transuranic Waste Storage and Assay Facility & $200 \mathrm{~W}$ & s & $200-T P-4$ \\
\hline PUREX Storage Tunnels & $200 E$ & s & $200-P O-2$ \\
\hline $325 / 3100$ Hazardous Waste Treatment Unit & 300 & TS & $300-F F-3$ \\
\hline Biological Treatment Test Facilities & 300 & $T$ & $300-F F-3$ \\
\hline Physical/Chemical Treatment Test Facilities & 300 & TS & $300-F F-3$ \\
\hline Thermal Treatment Test Facilities & 300 & $T$ & $300-F F-3$ \\
\hline 305-8 Storage Unit & 300 & $\mathrm{~s}$ & $300-F F-3$ \\
\hline Maintenance and Storage Facility & 400 & $T$ & $300-F F-4$ \\
\hline 616 Nonradioactive Dangerous Waste Storage Facility & 600 & $\mathrm{~s}$ & $200-14-6$ \\
\hline 600 Area Purgewater Storage and Treatment Facility & 600 & TS & $200-B P-11$ \\
\hline
\end{tabular}

Unit-- Name of TSD unit for which final status is sought (as of March 15, 1993) as part of the Hanford Facility (EPA/State Identification Number WA7890008967).

Area-- The area of the Hanford Facility in which the unit is located:

$200 \mathrm{E}$-. 200 East Area

$200 \mathrm{~W}$.- 200 West Area

200EW -. Parts of a unit are located

in both the 200 East and

the 200 West Areas

Class--Waste unit operational classification T--Ireatment

S--Storage D.-Disposal.

- 300 Area

- 400 Area

- 600 Area. 


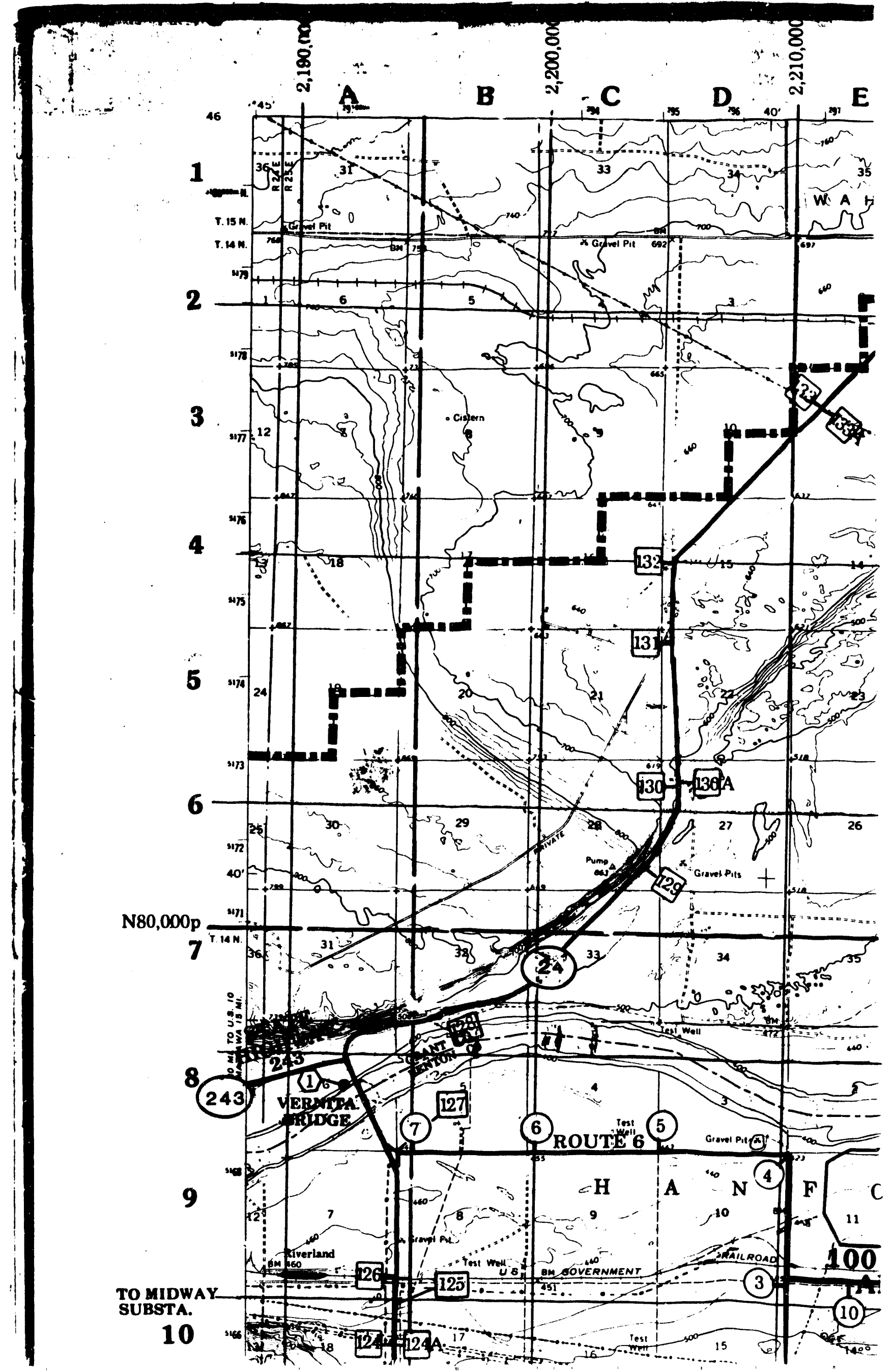




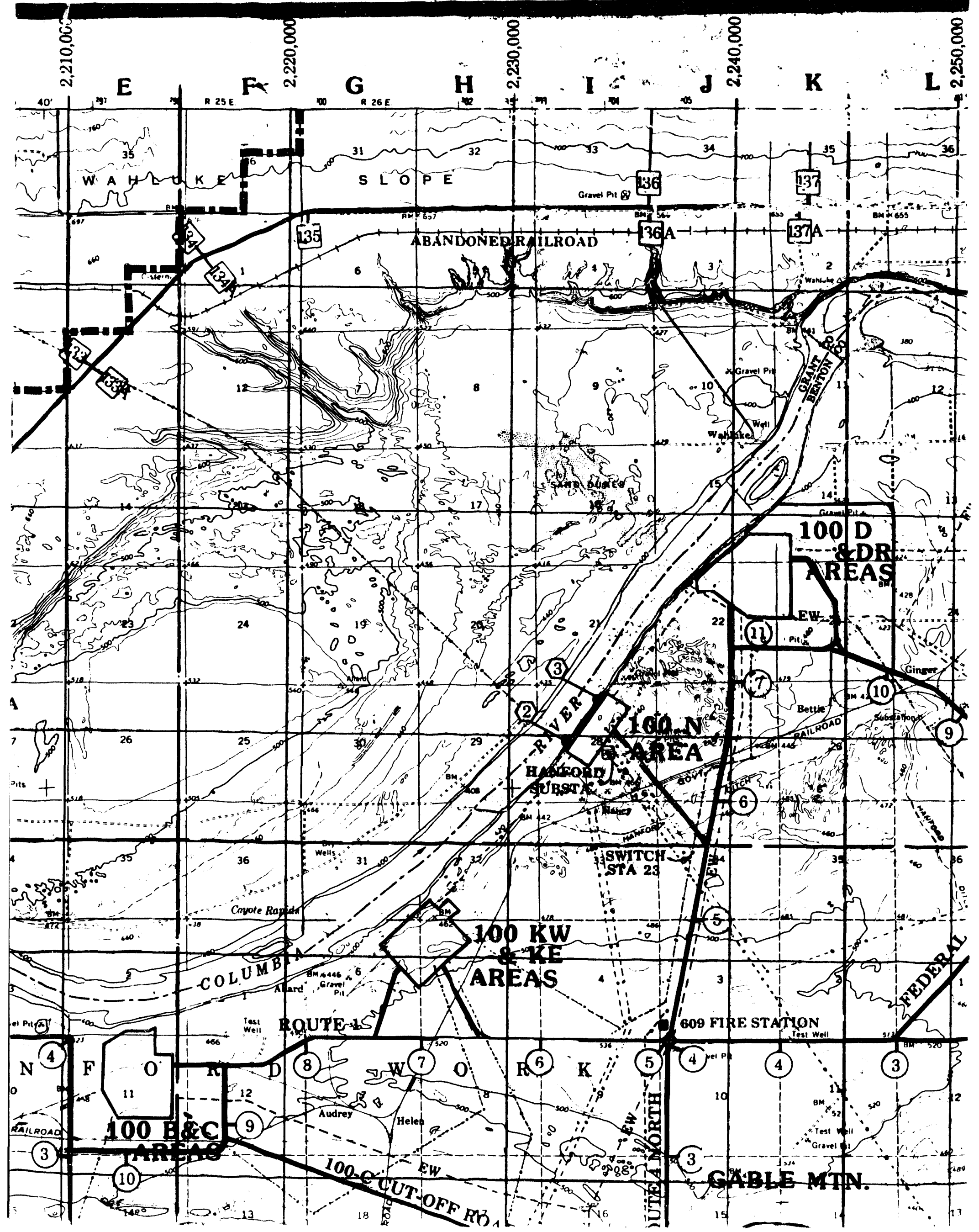




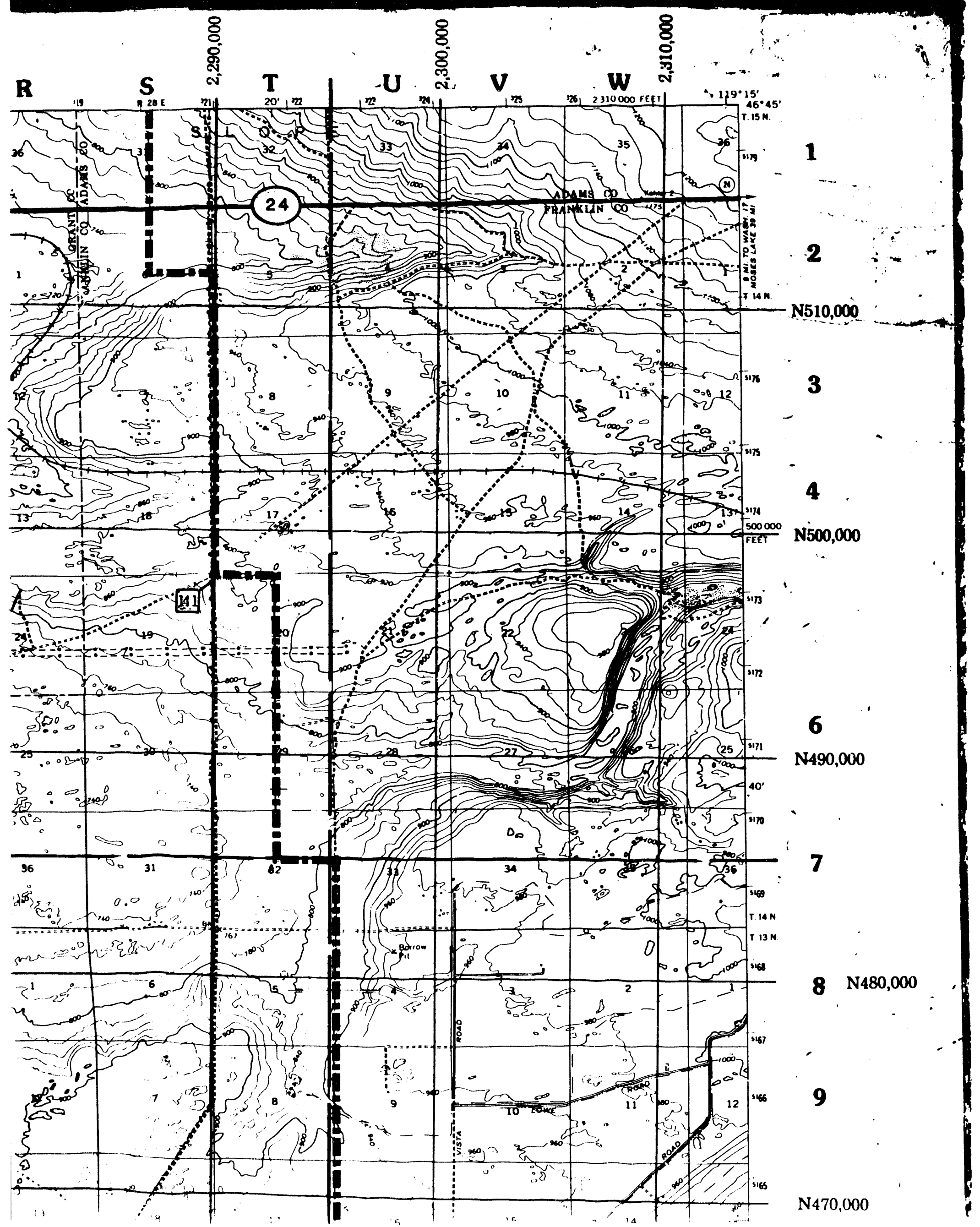




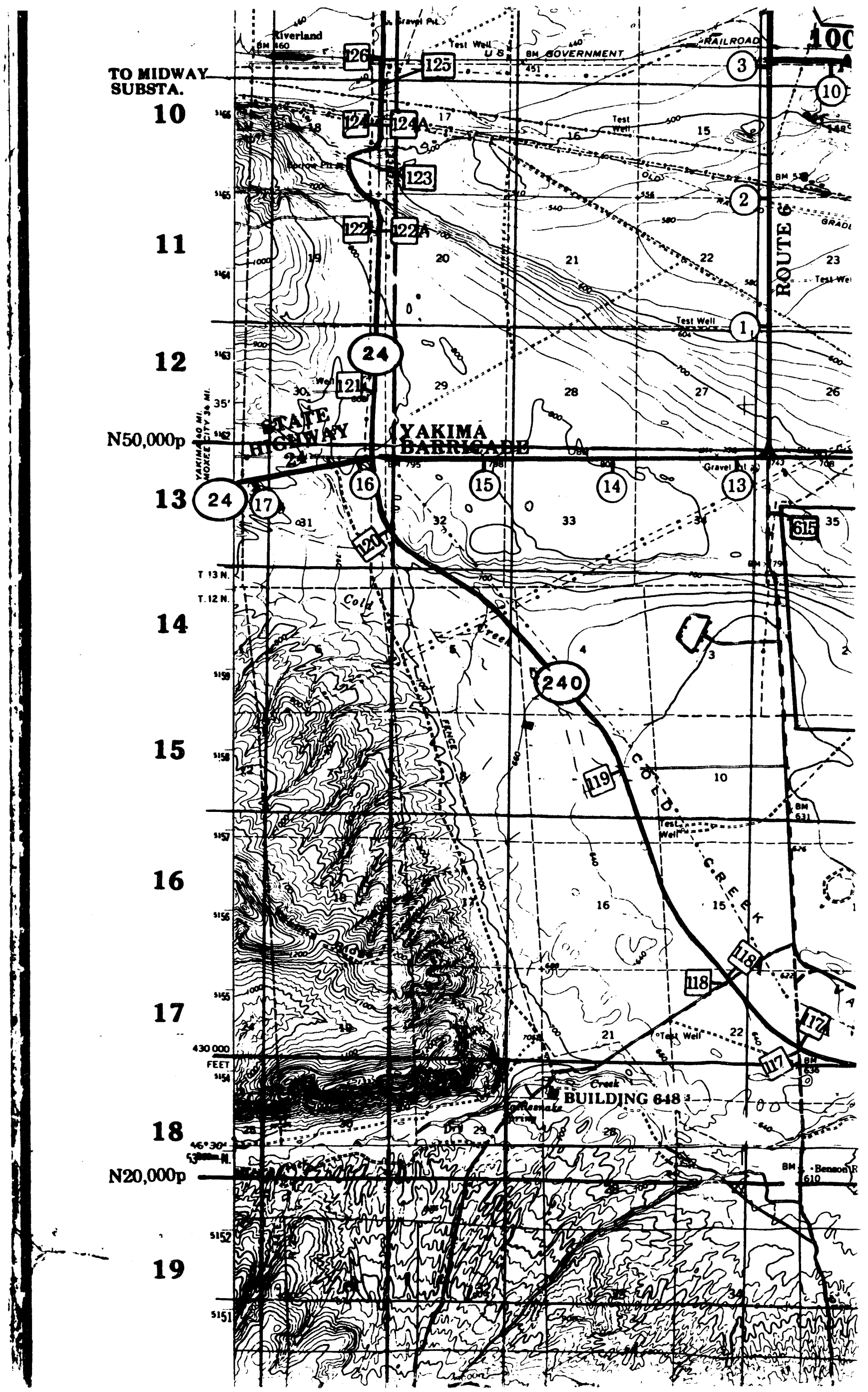




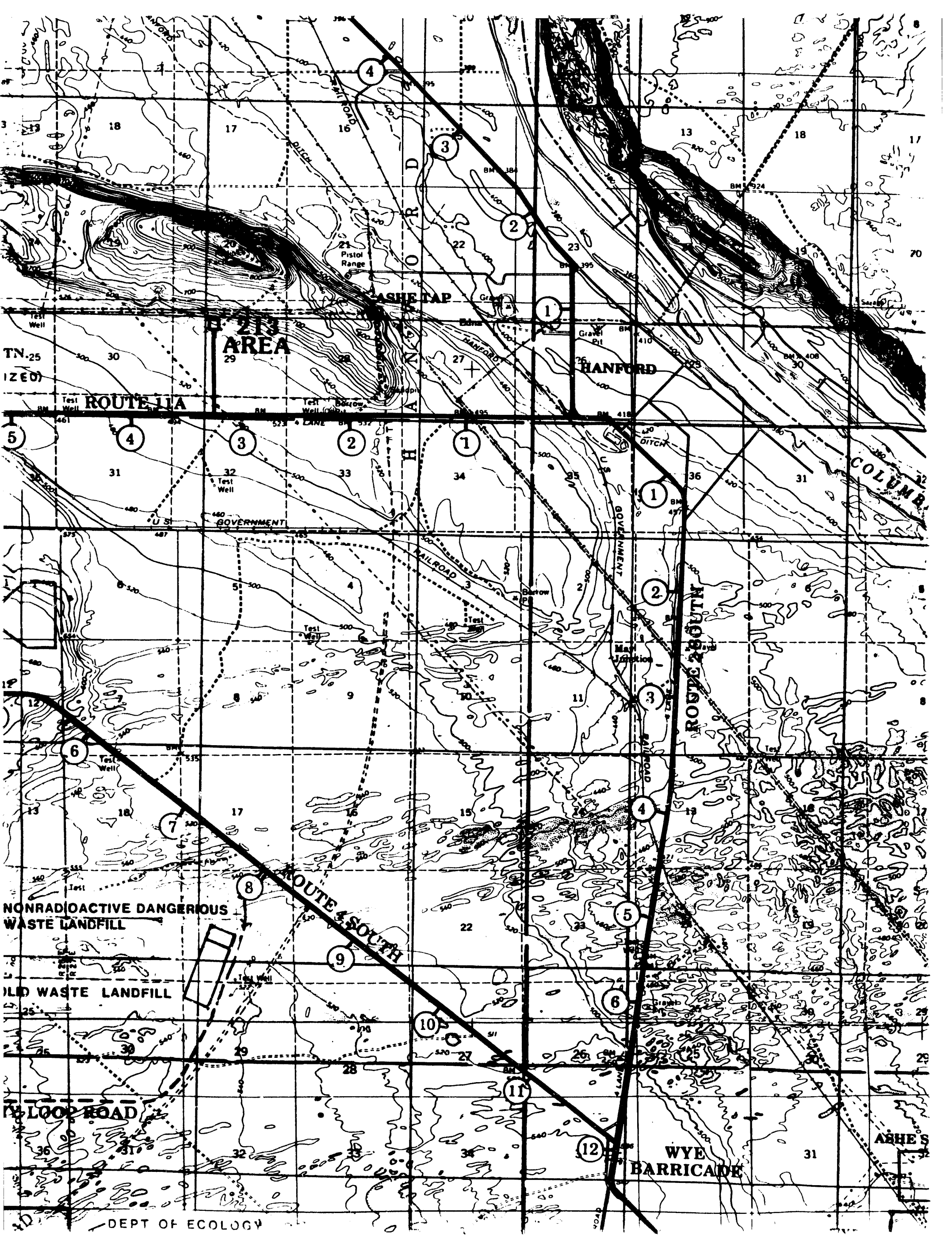


sag

21<smiles></smiles>

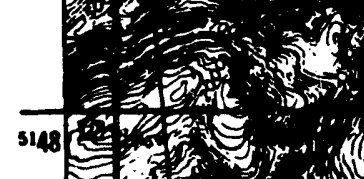
- ent

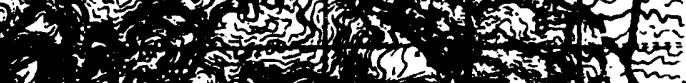

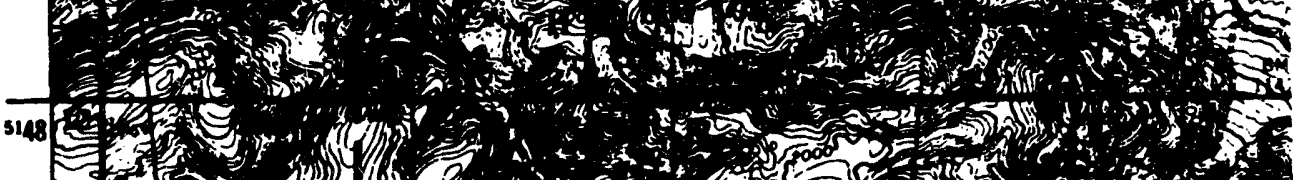

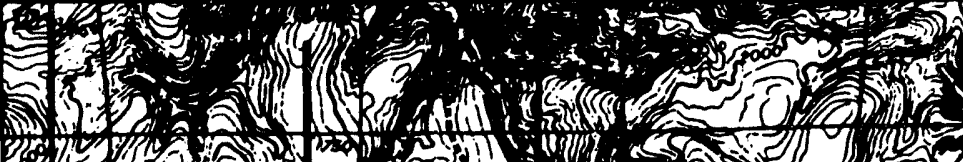

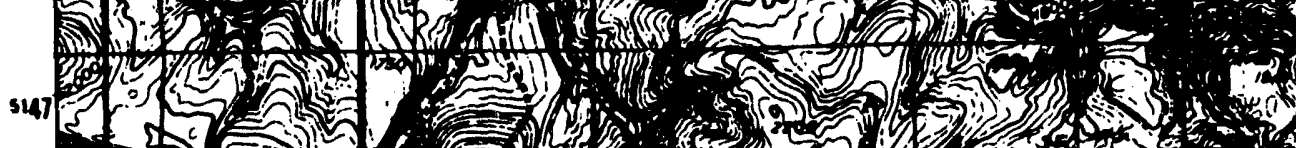

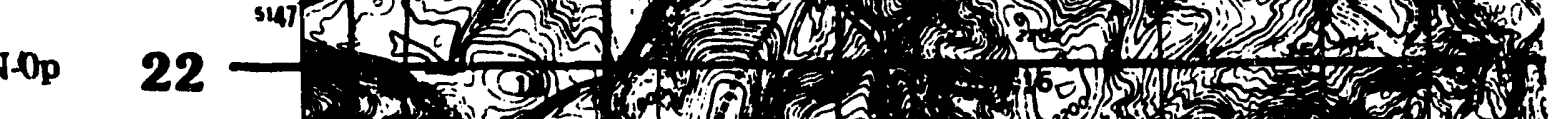

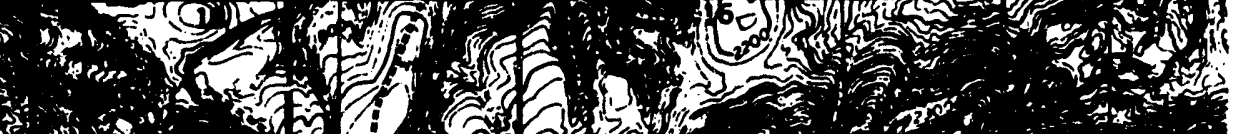
11\% (3) 综窟

23

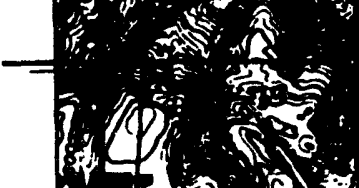
tos

S10.000p 25.

24

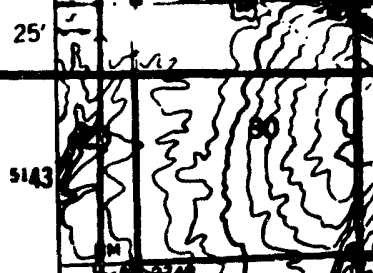
$14 x^{2}$ And

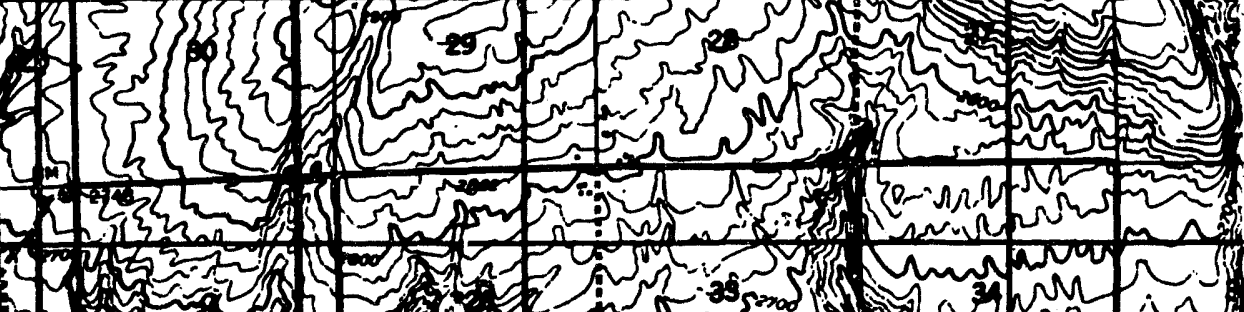

25 s.0.
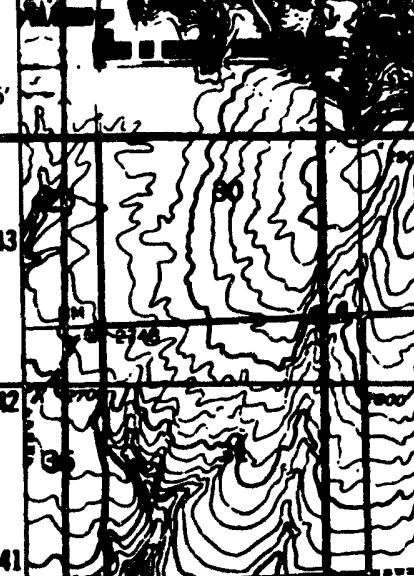
(2) 4 , 


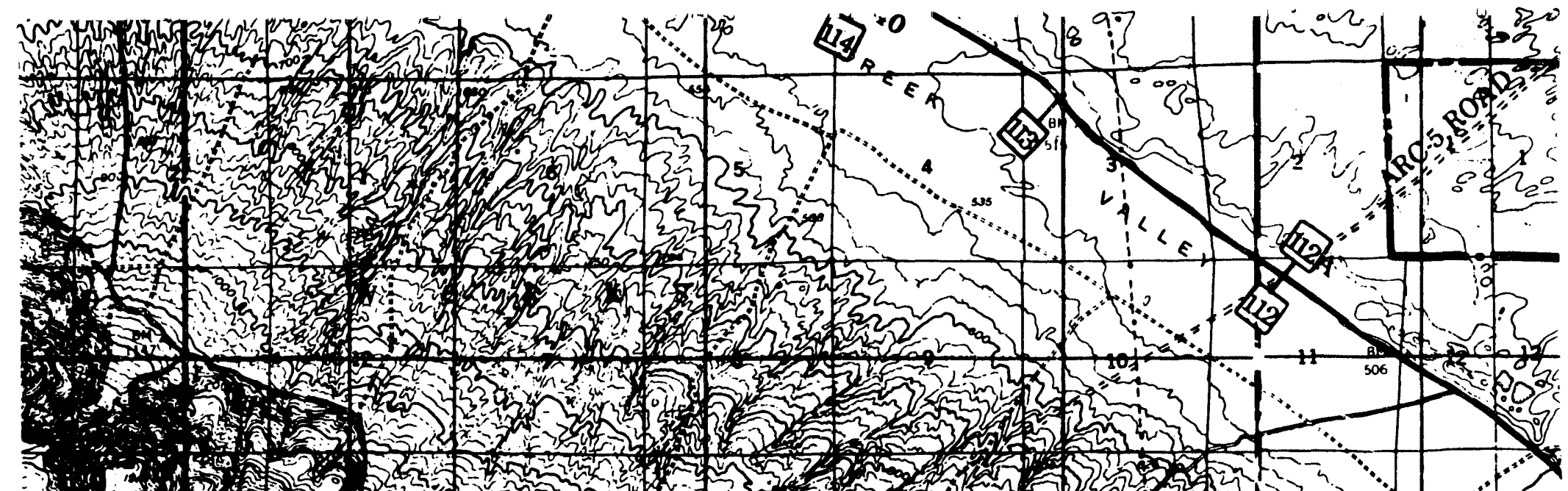

S.
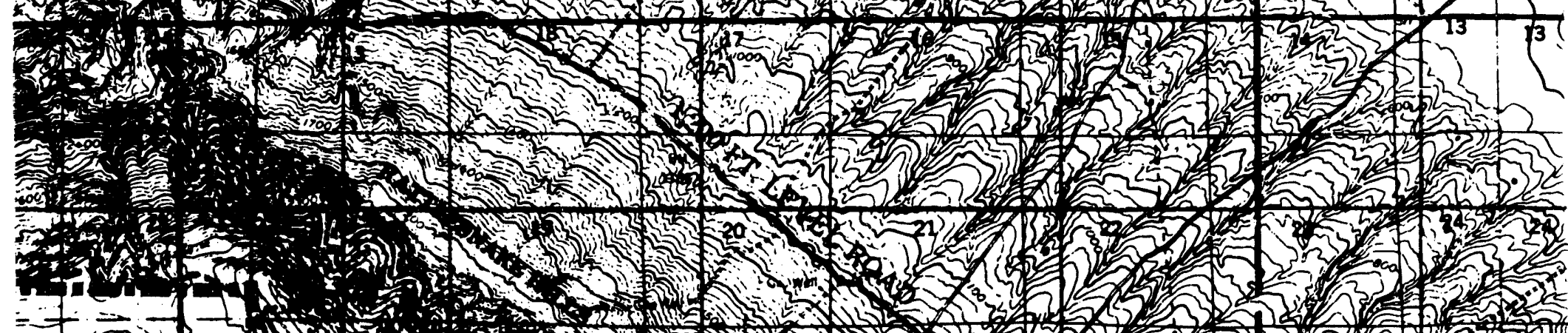

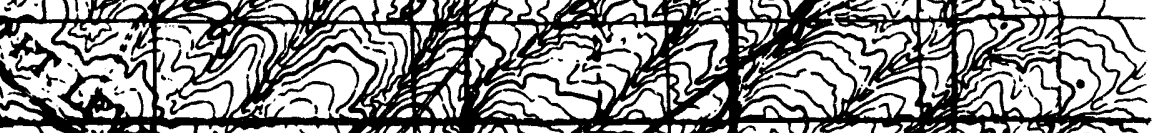
(20.2)

Strox

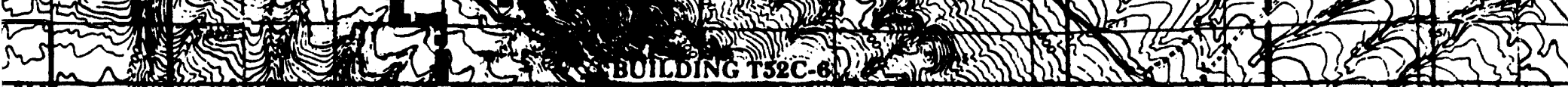
MU

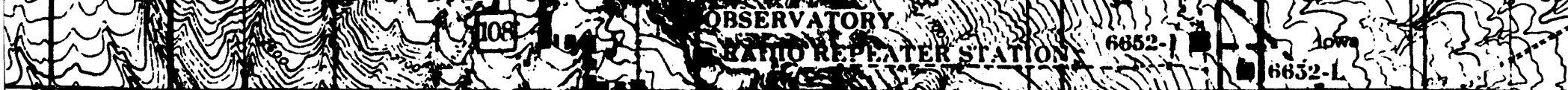
(1) LEGEND

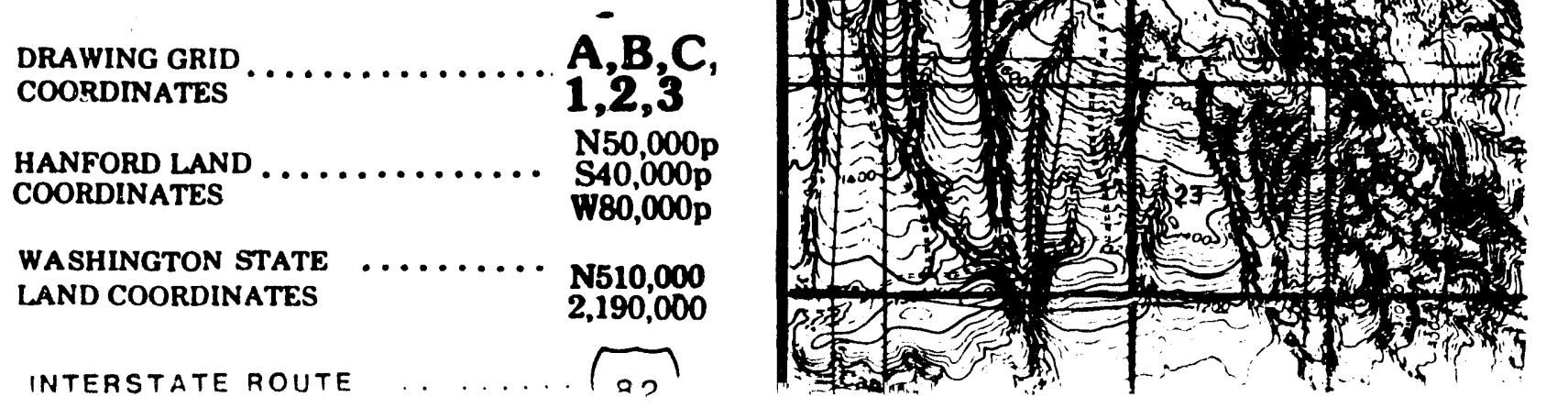




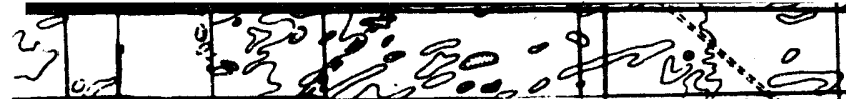

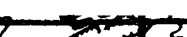

\section{arom}

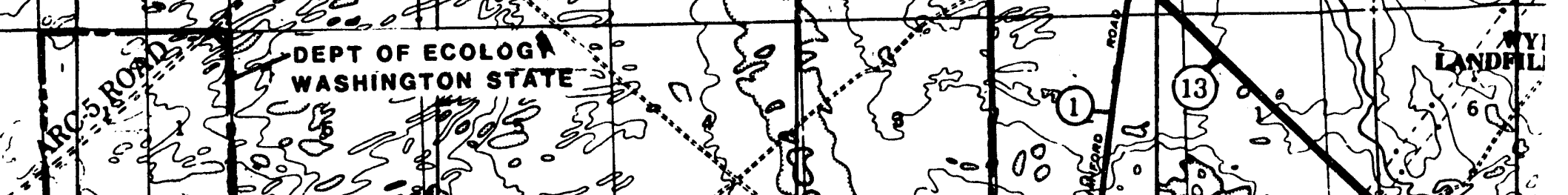

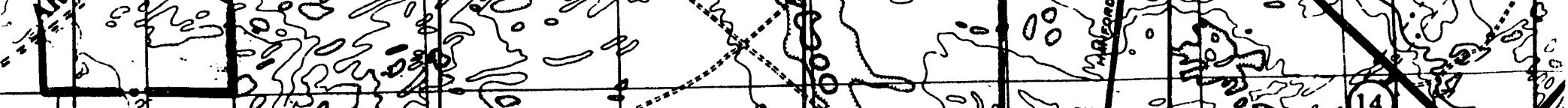
ant 年 2)

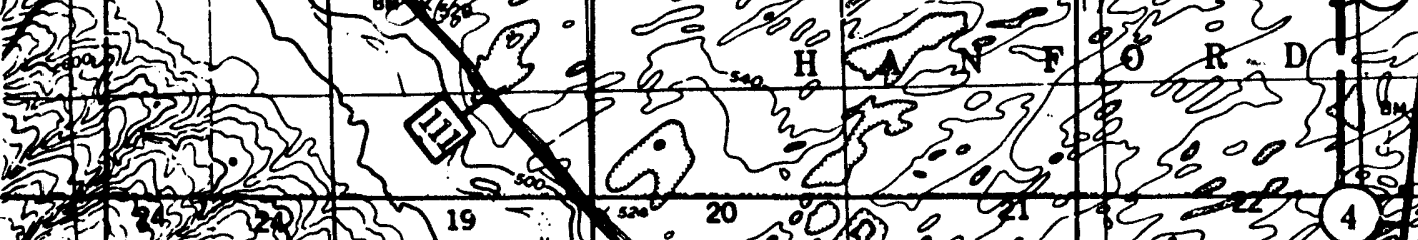

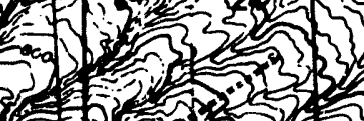

1)

14.

.

22

25: 14

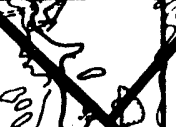
洒

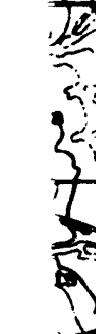

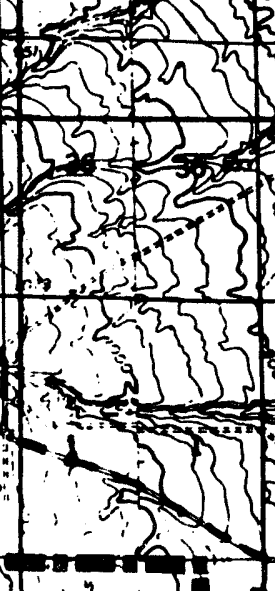

312 .

201300 . (3) 190 So 50 :

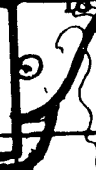
(1) AlRAs 


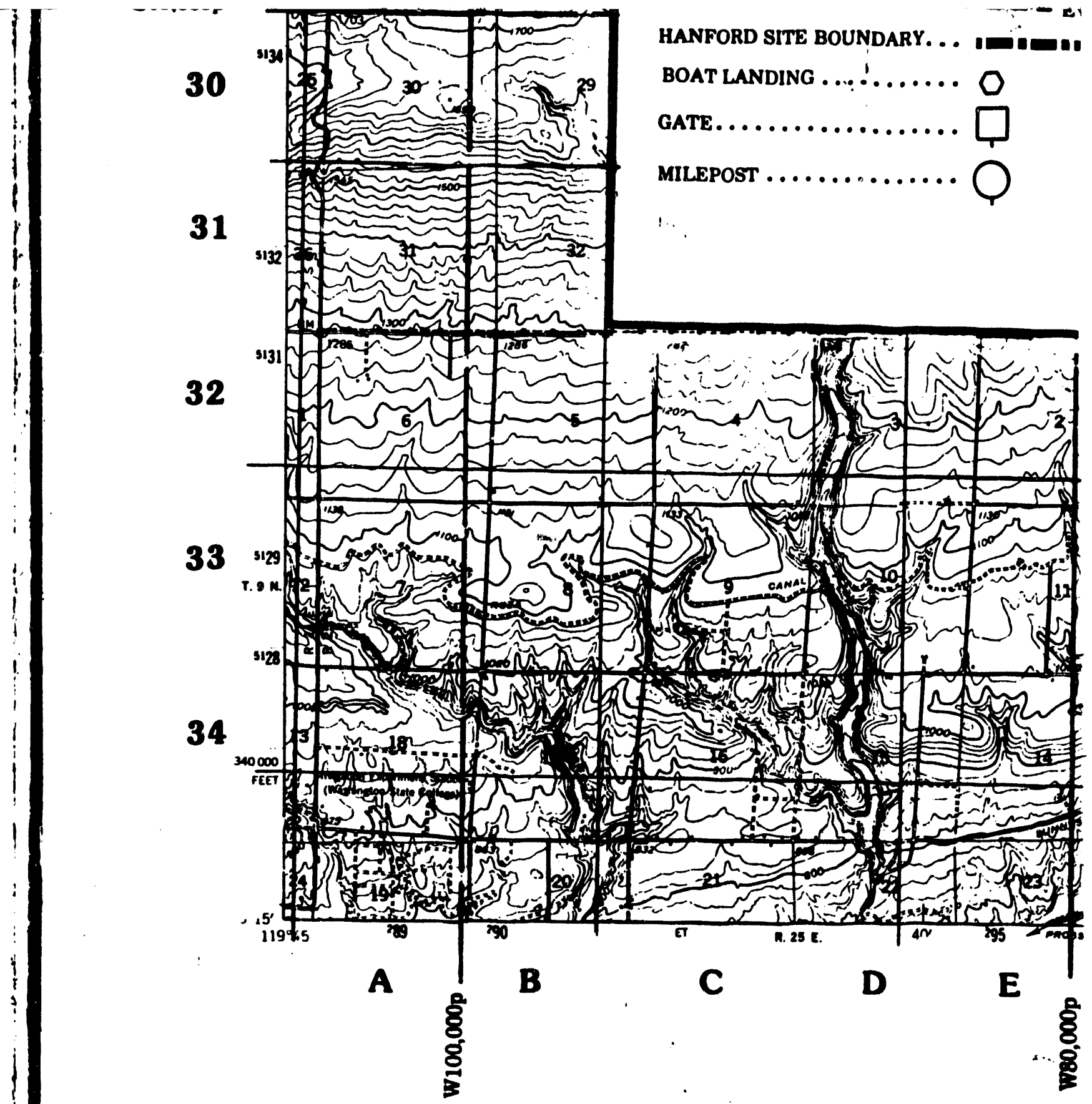

\section{NUTE}

APPROYAL TO CHAWLE THIS MAP MUST Z3E OBTH THE ENVIR̃ONMENTAL DIVIS:ON, RCFA PEF: EECAUSE THIS MAP WAS SUEMITTEU WITI. APPLICATIONS. TO THE MASHINGTON DERAF
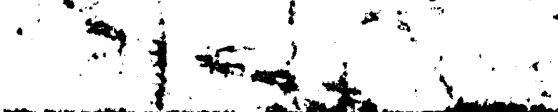


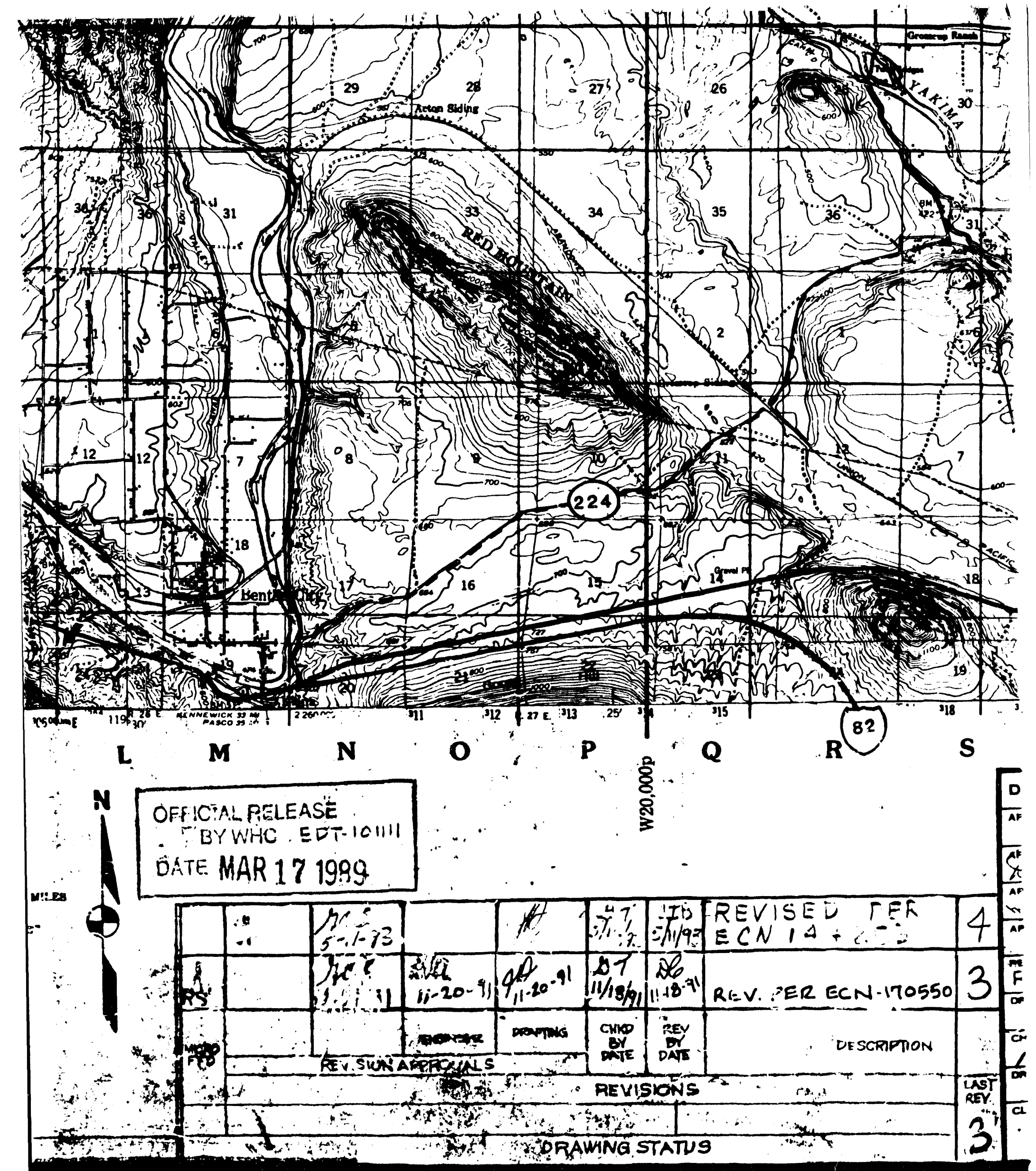




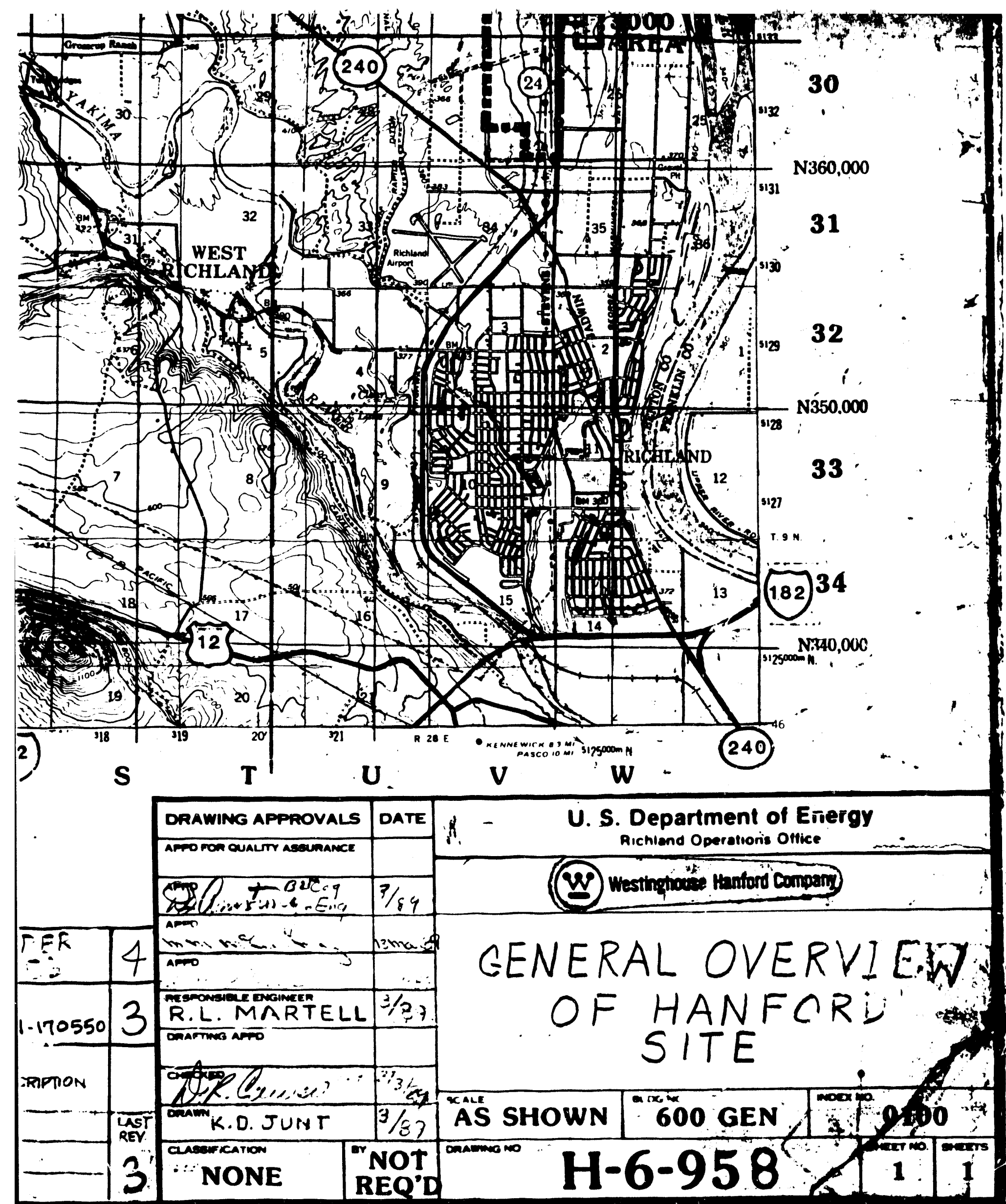




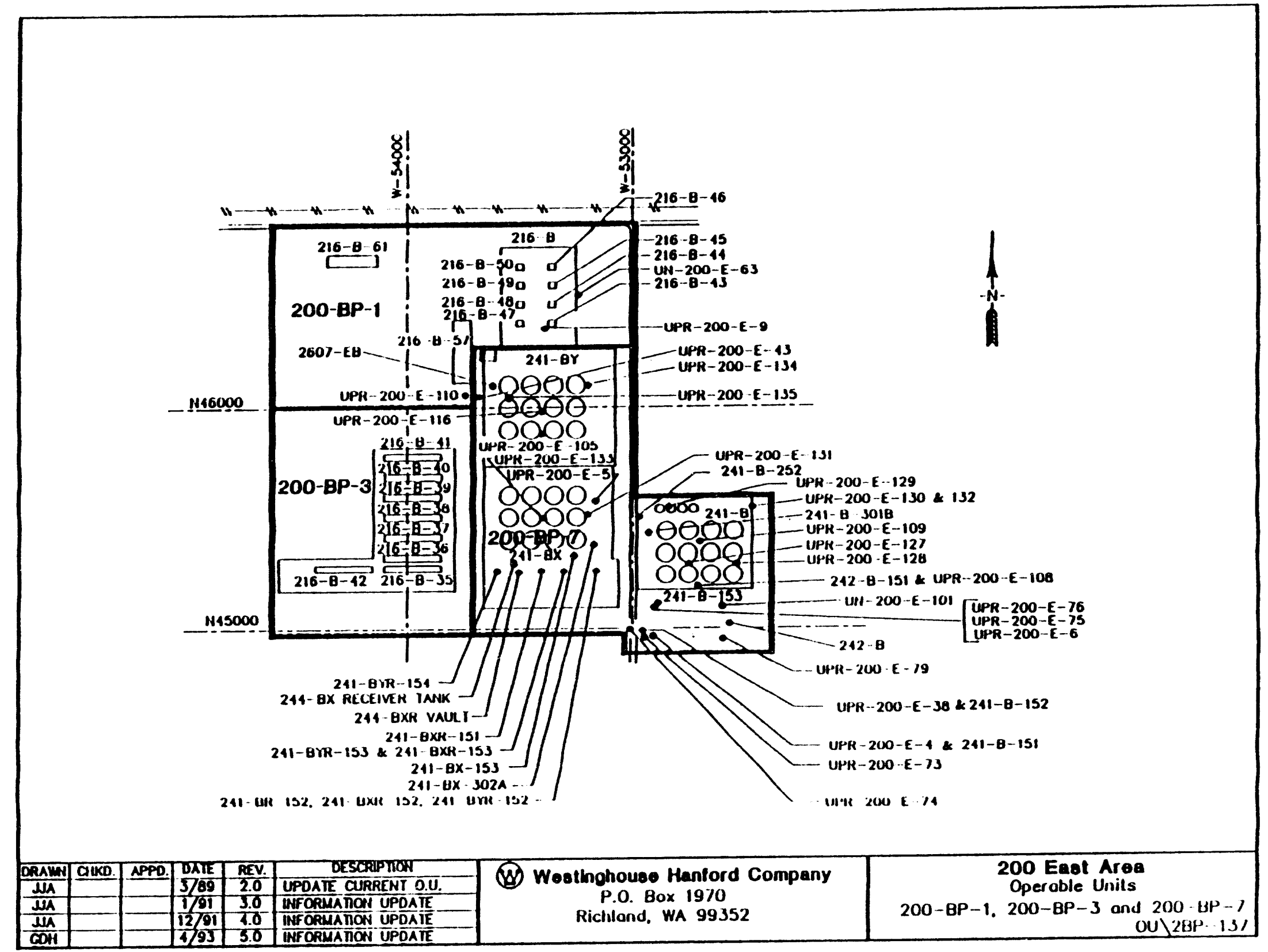




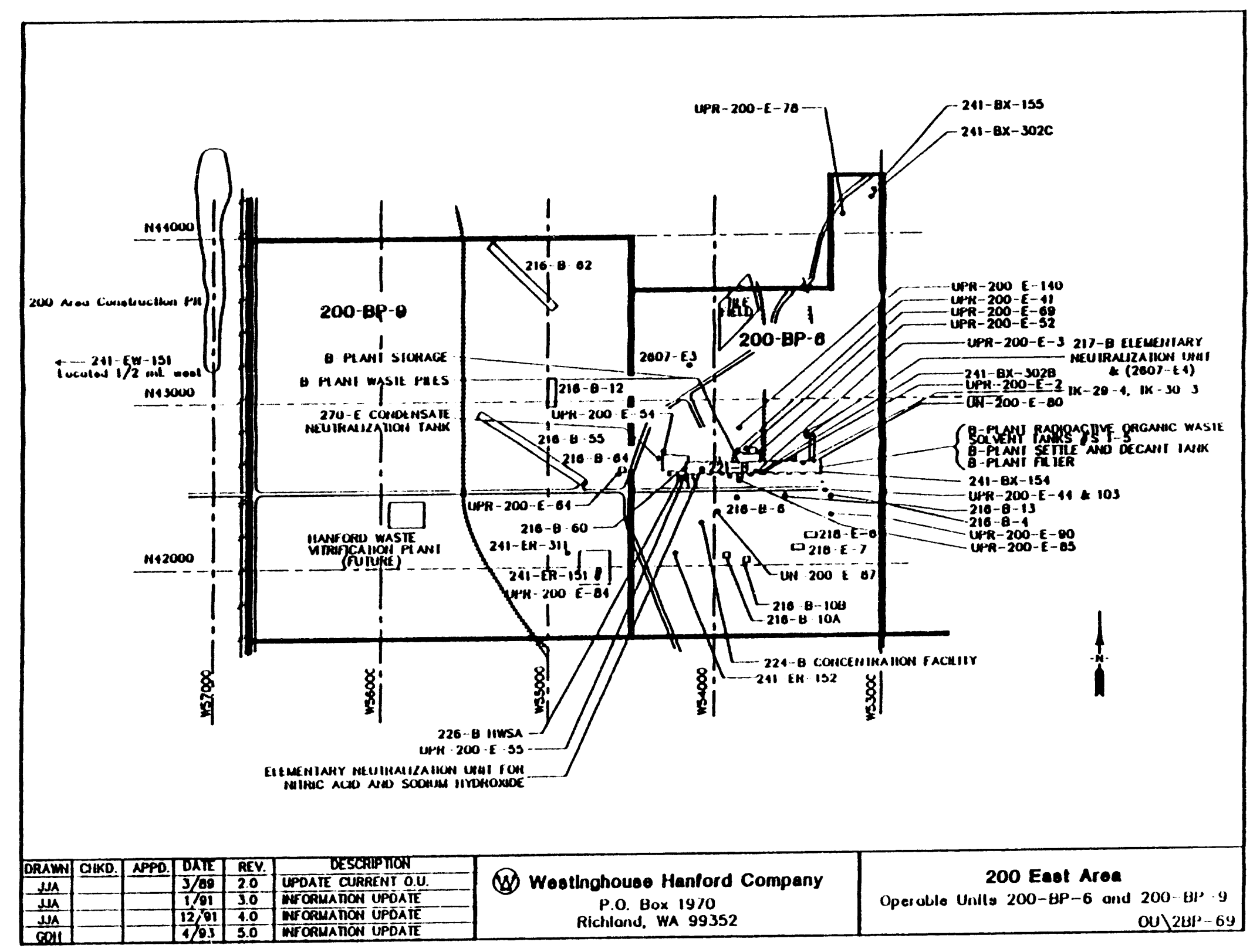




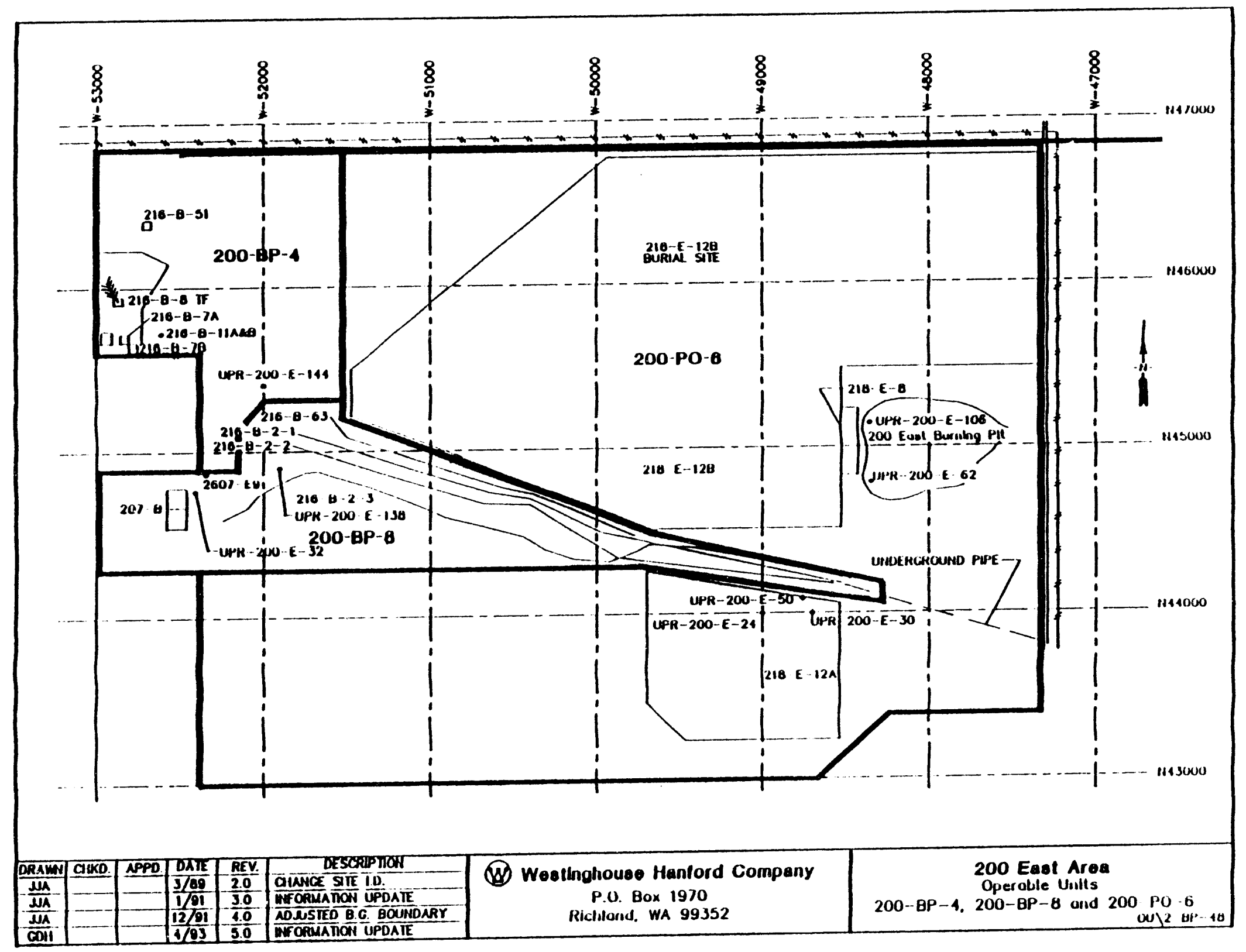




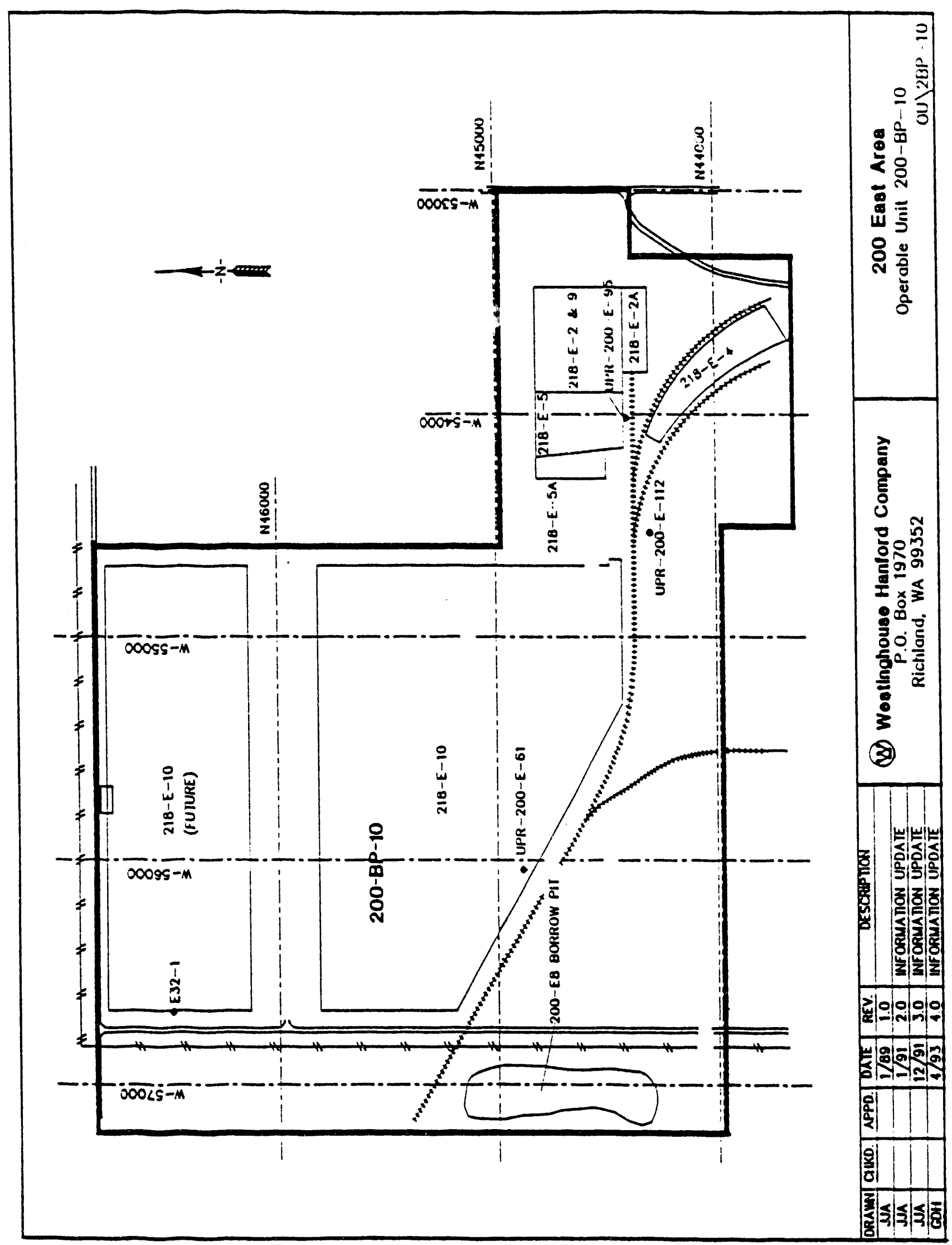




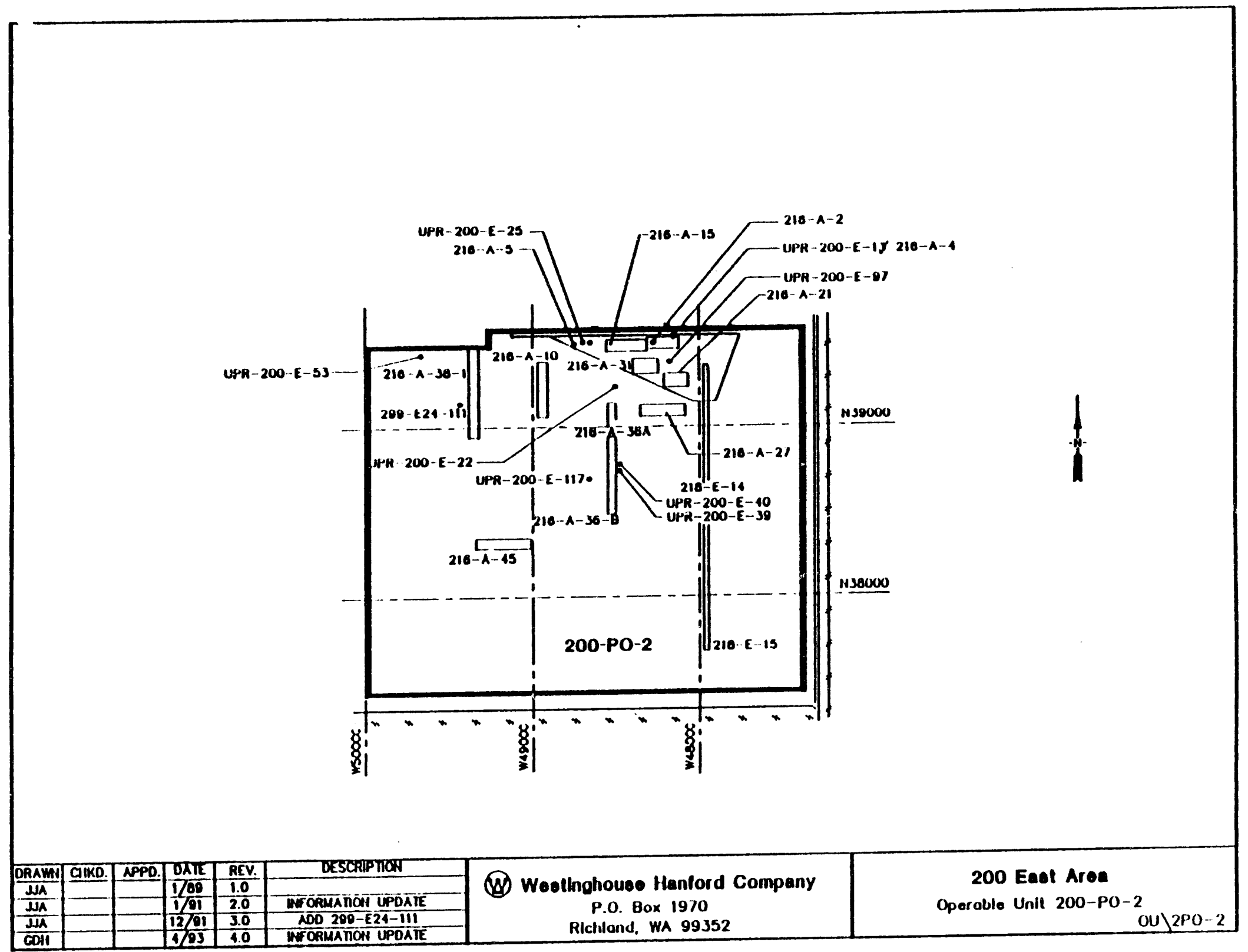




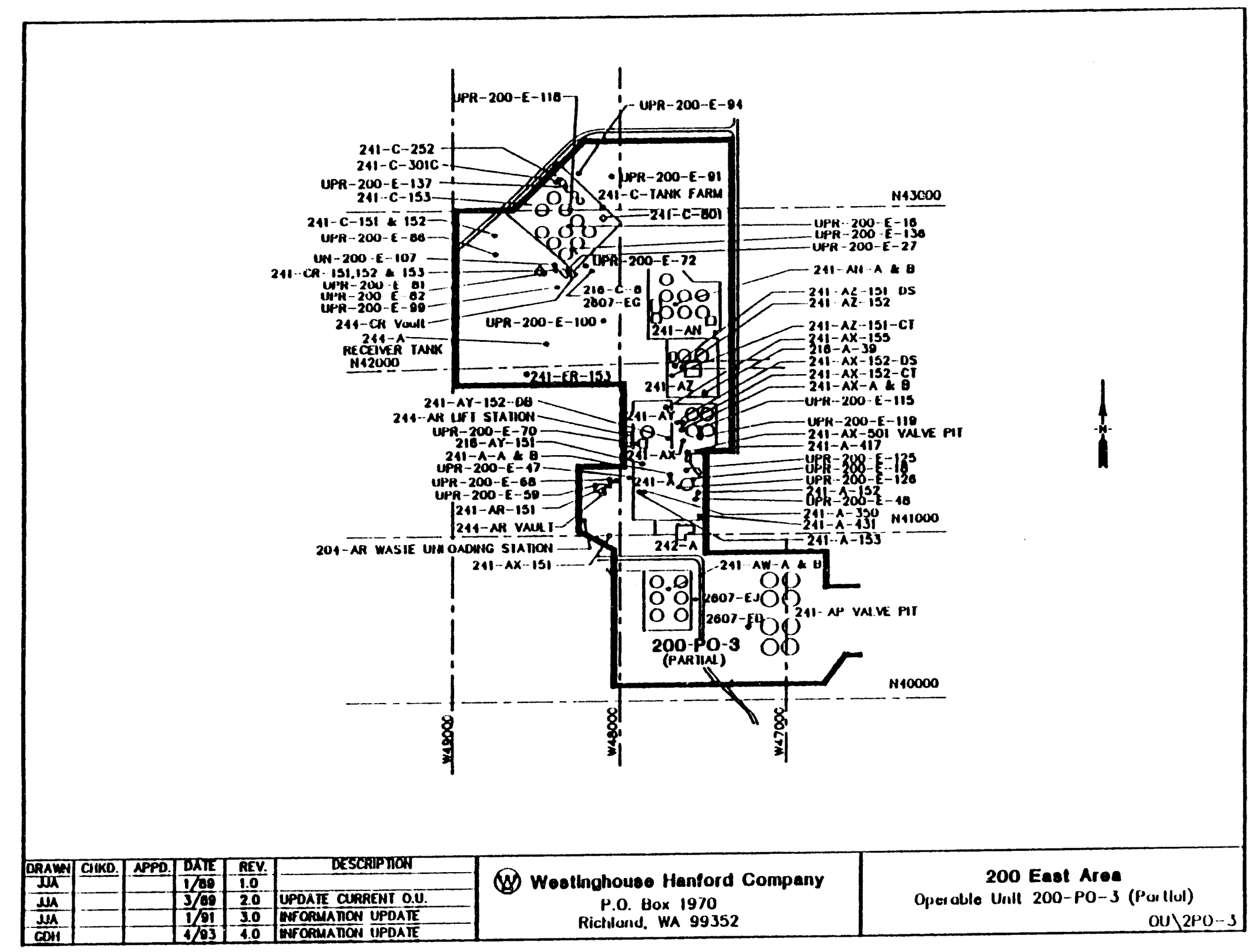




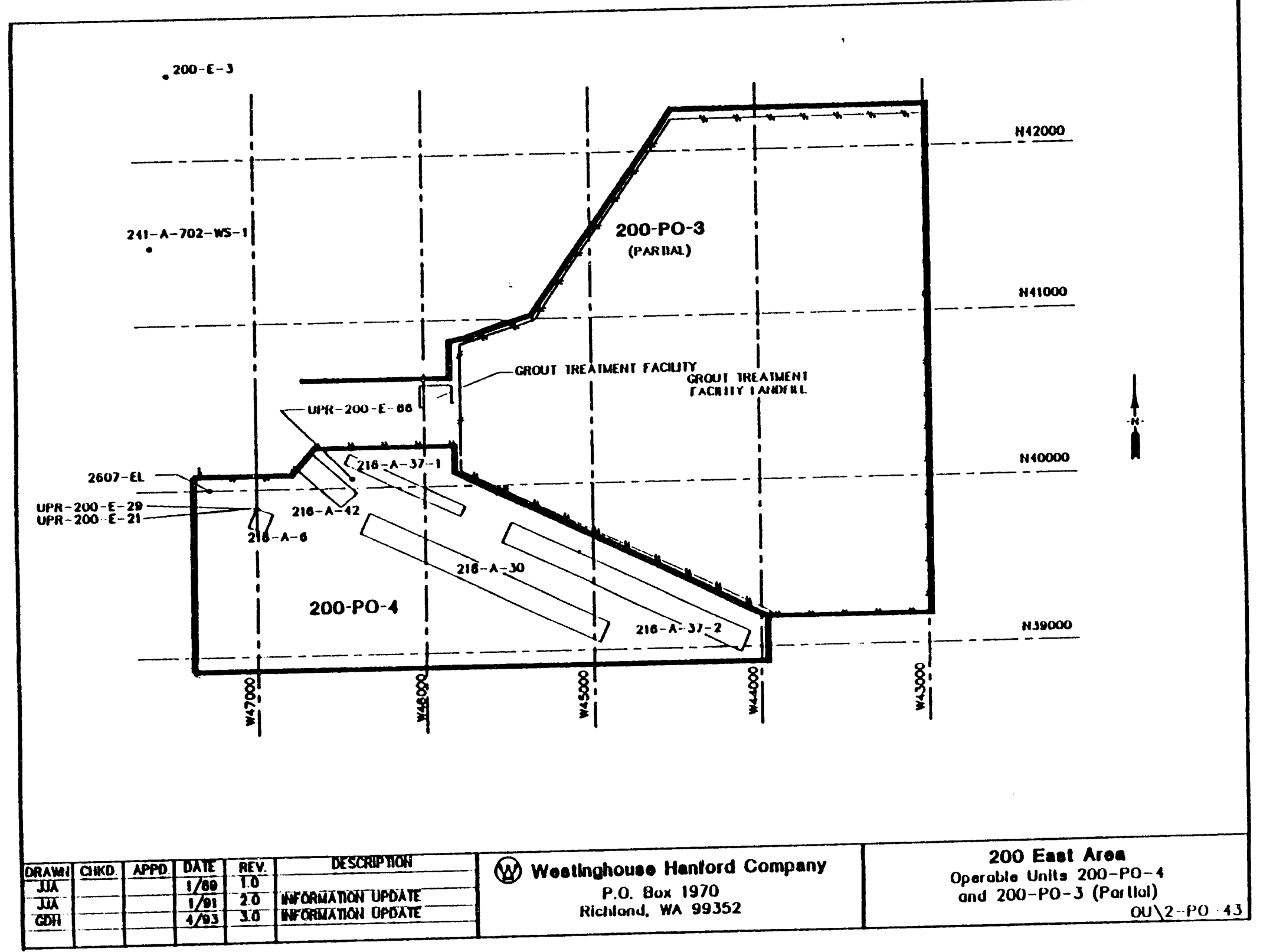




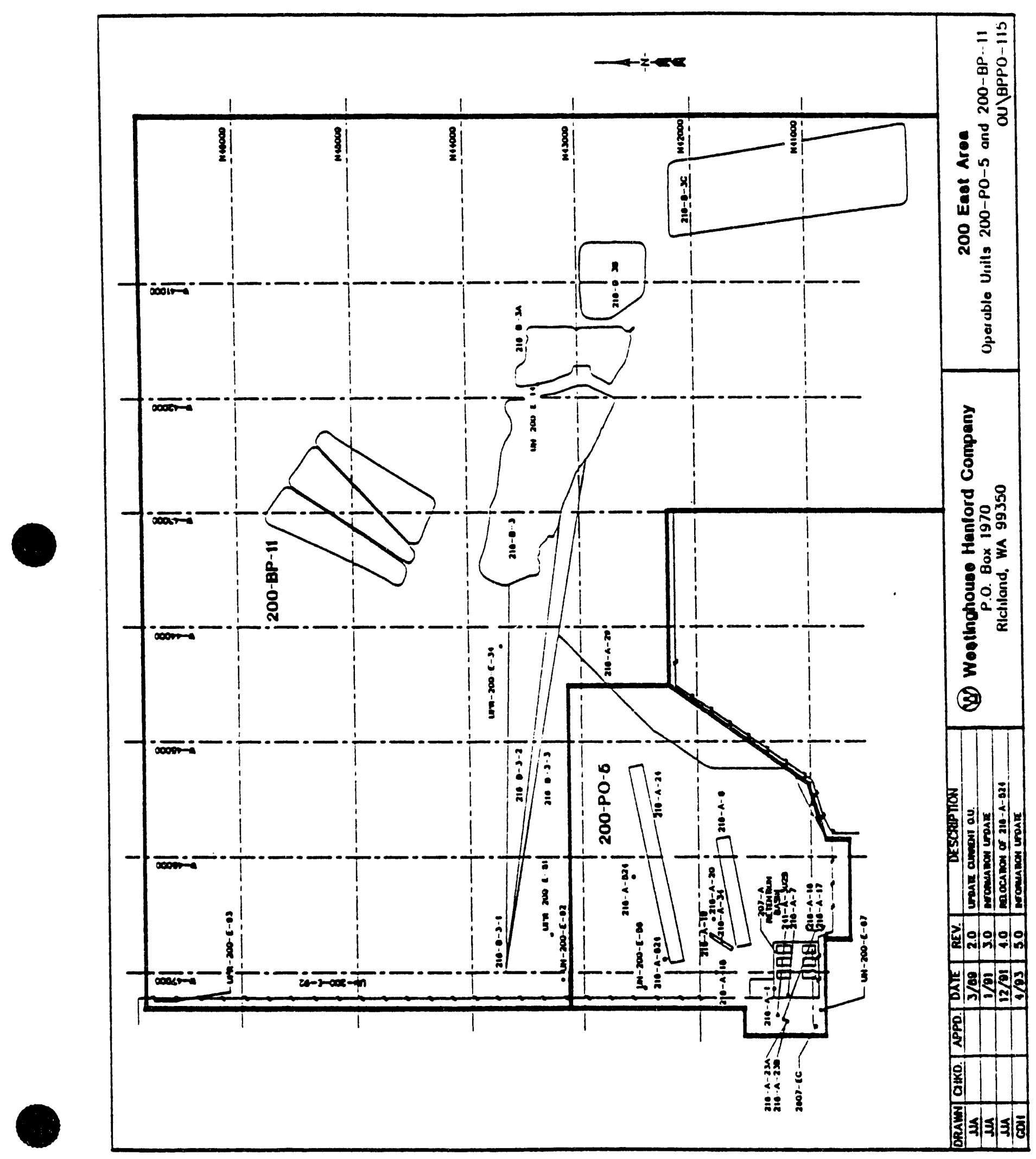




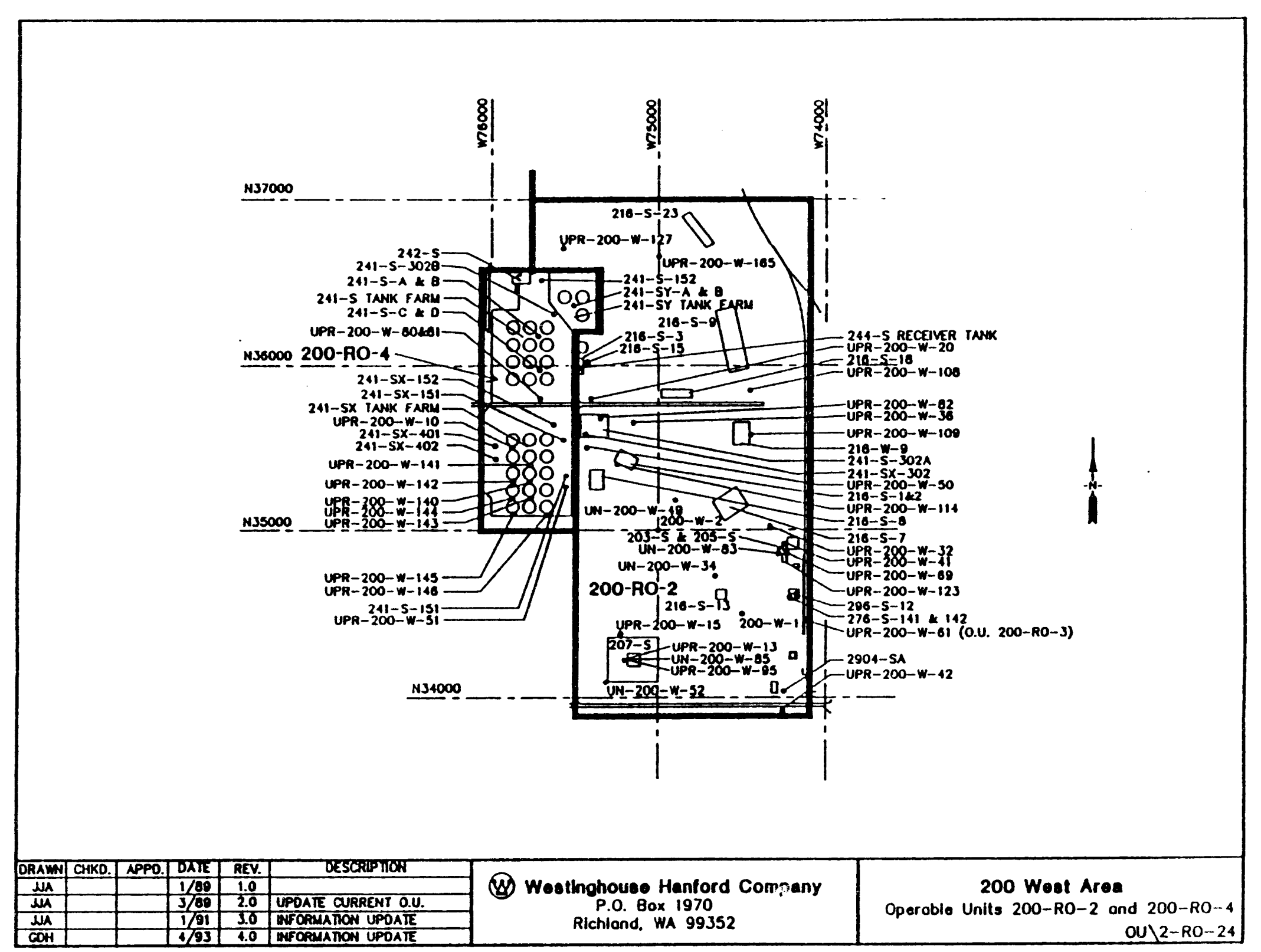




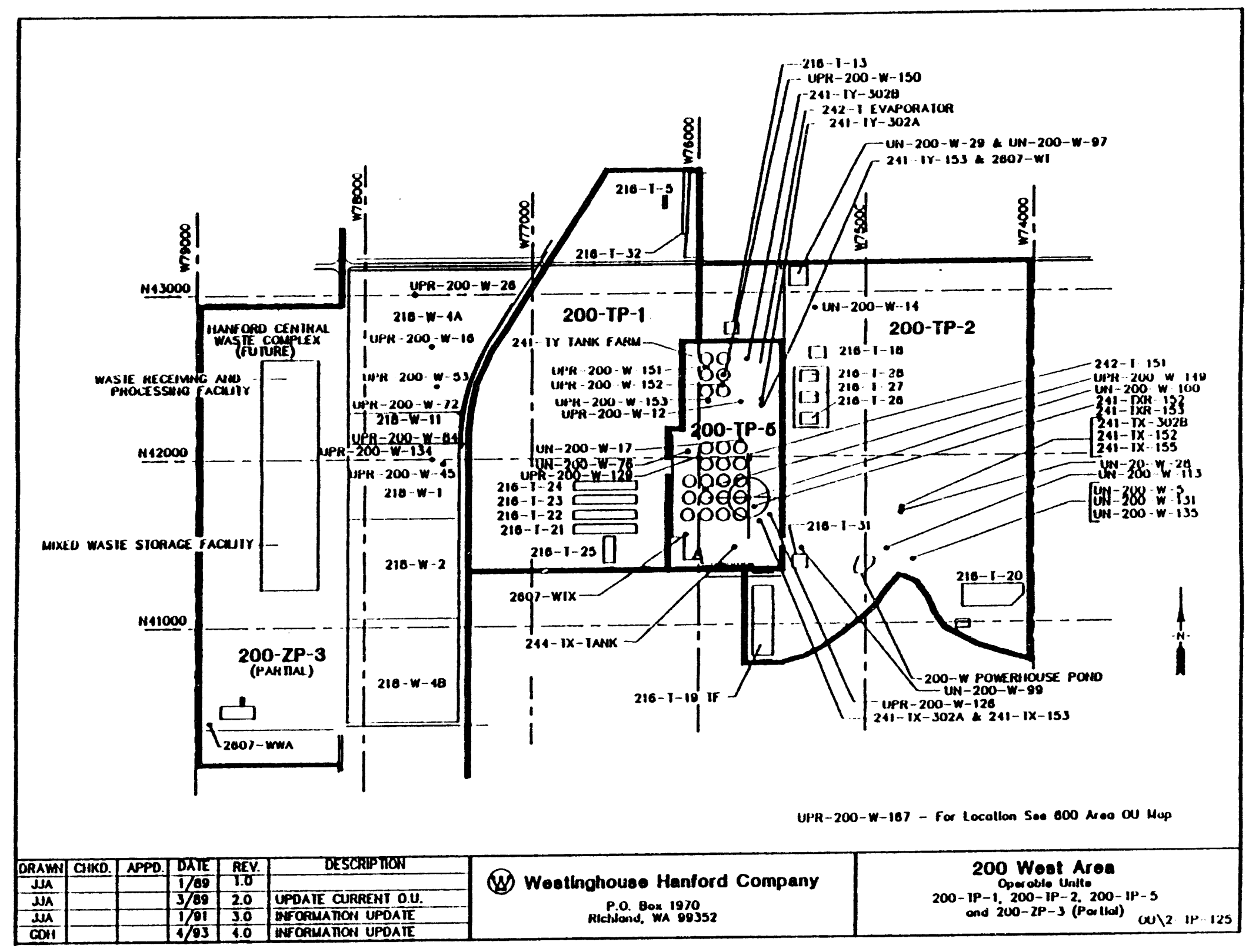




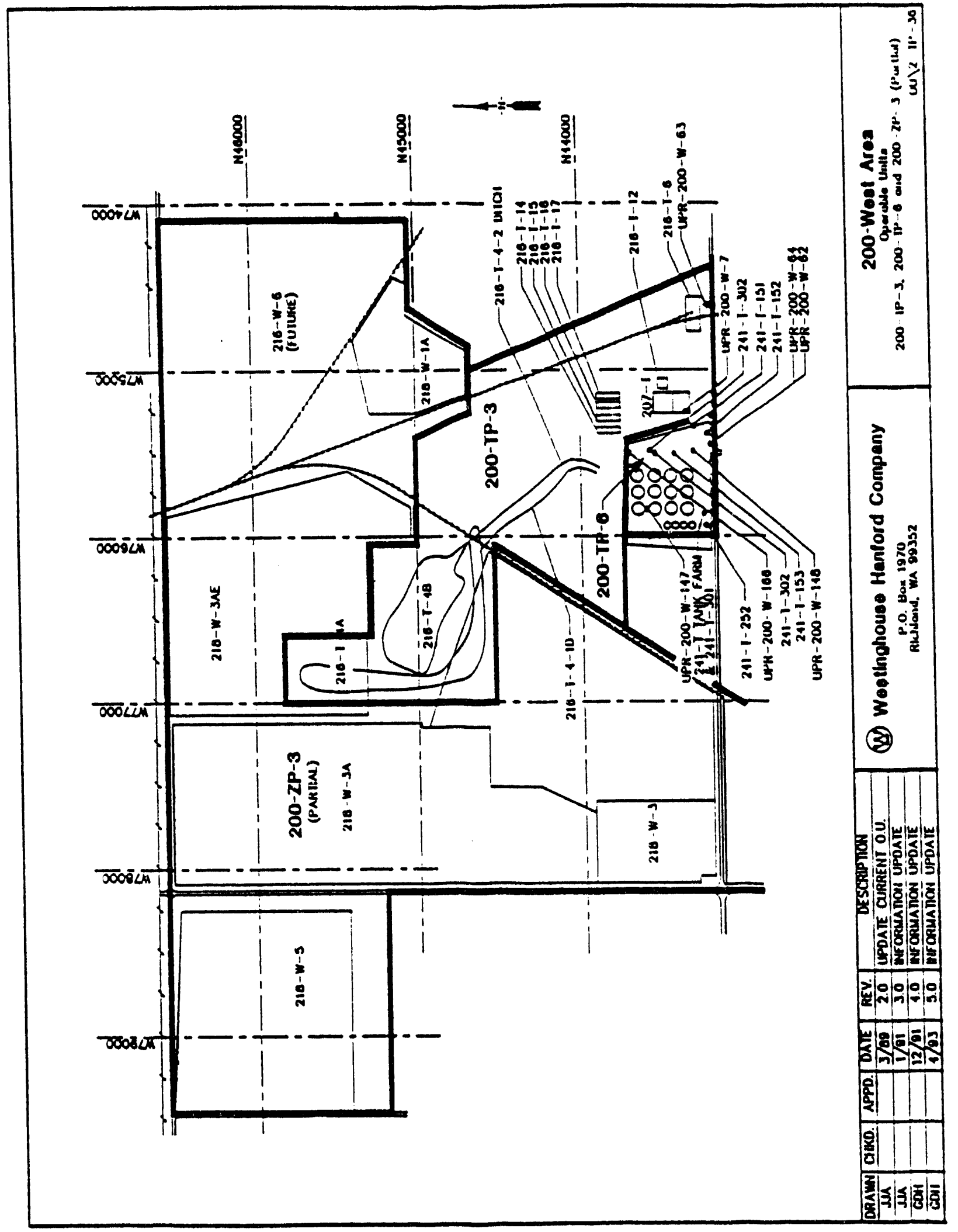




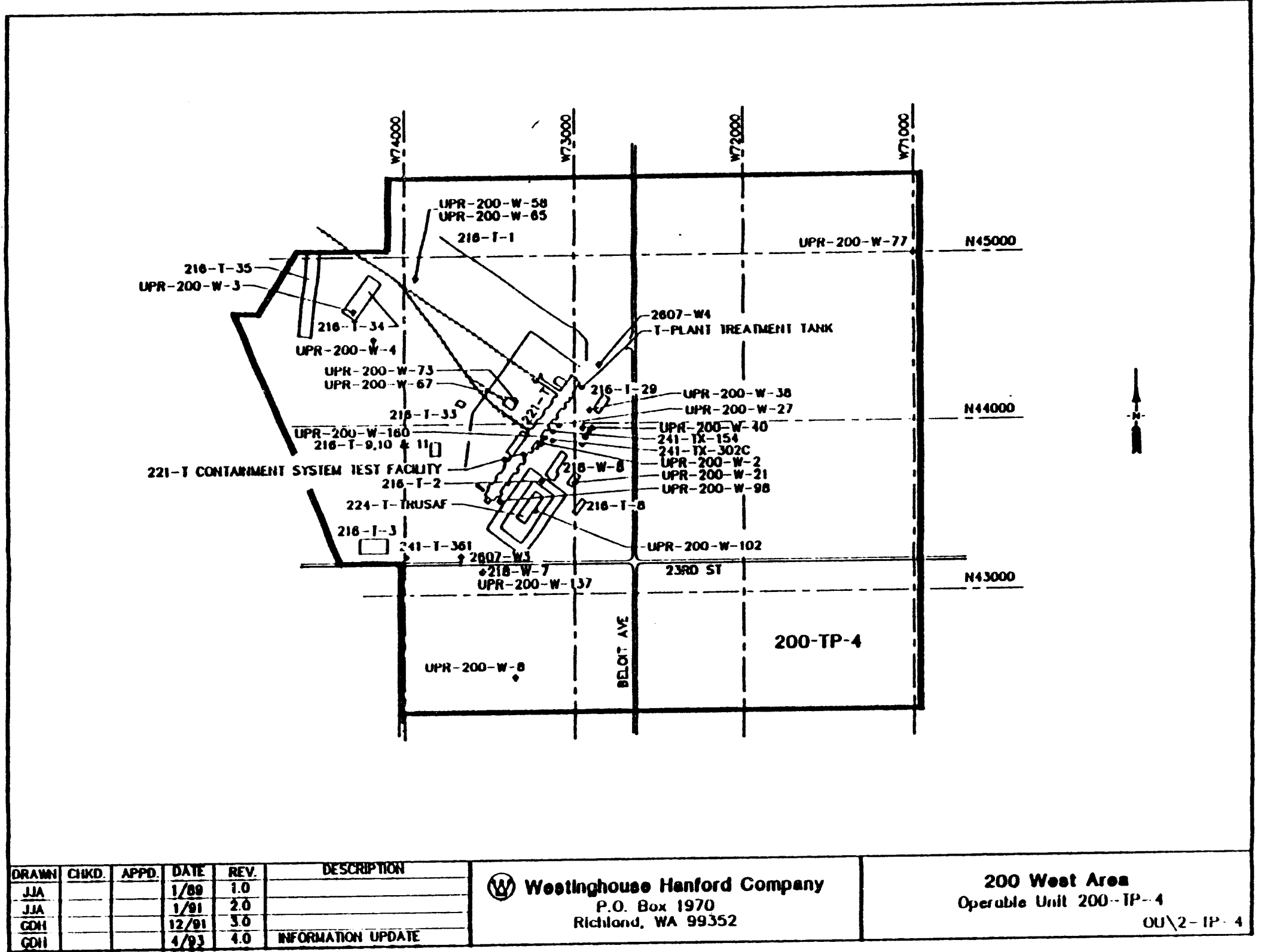





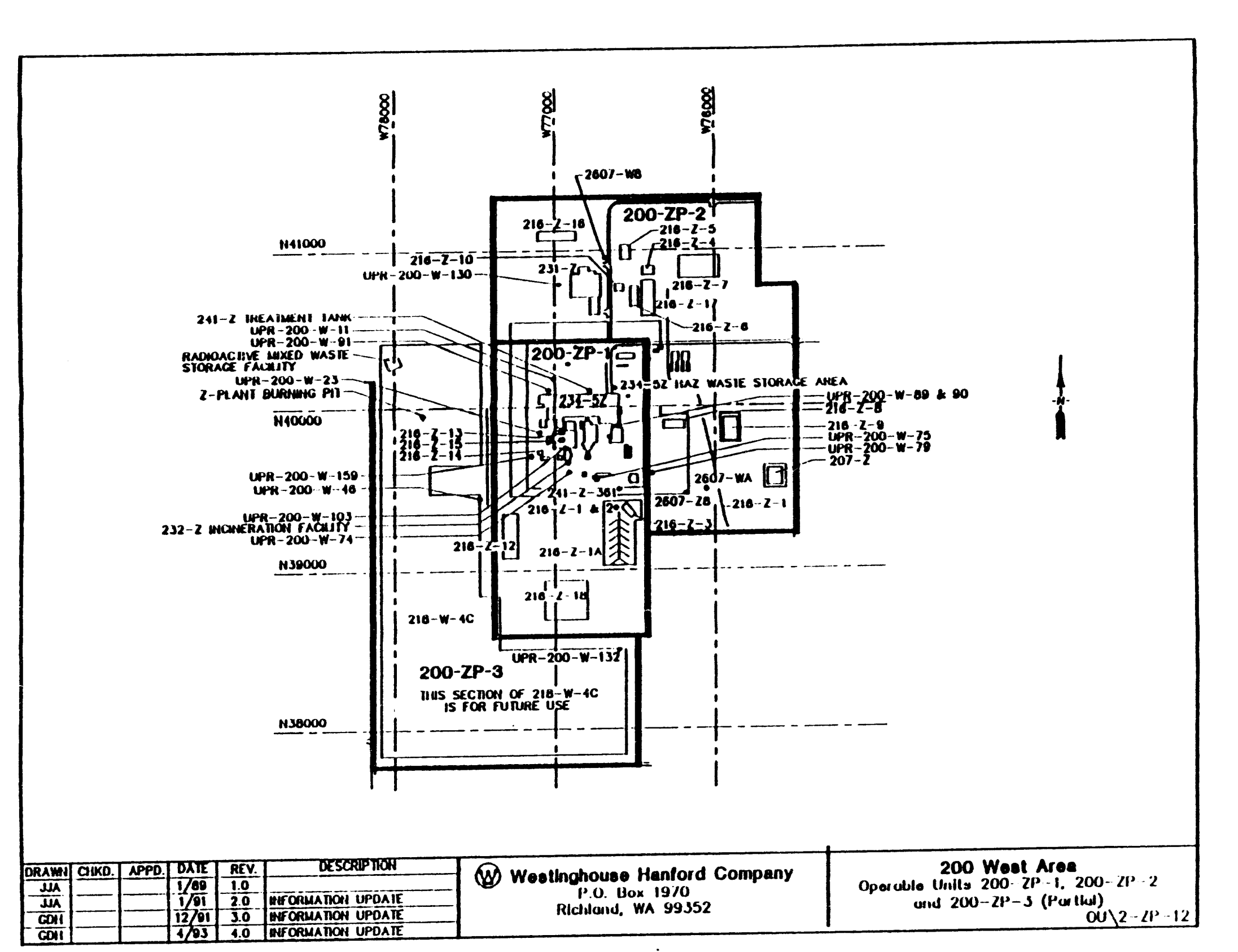




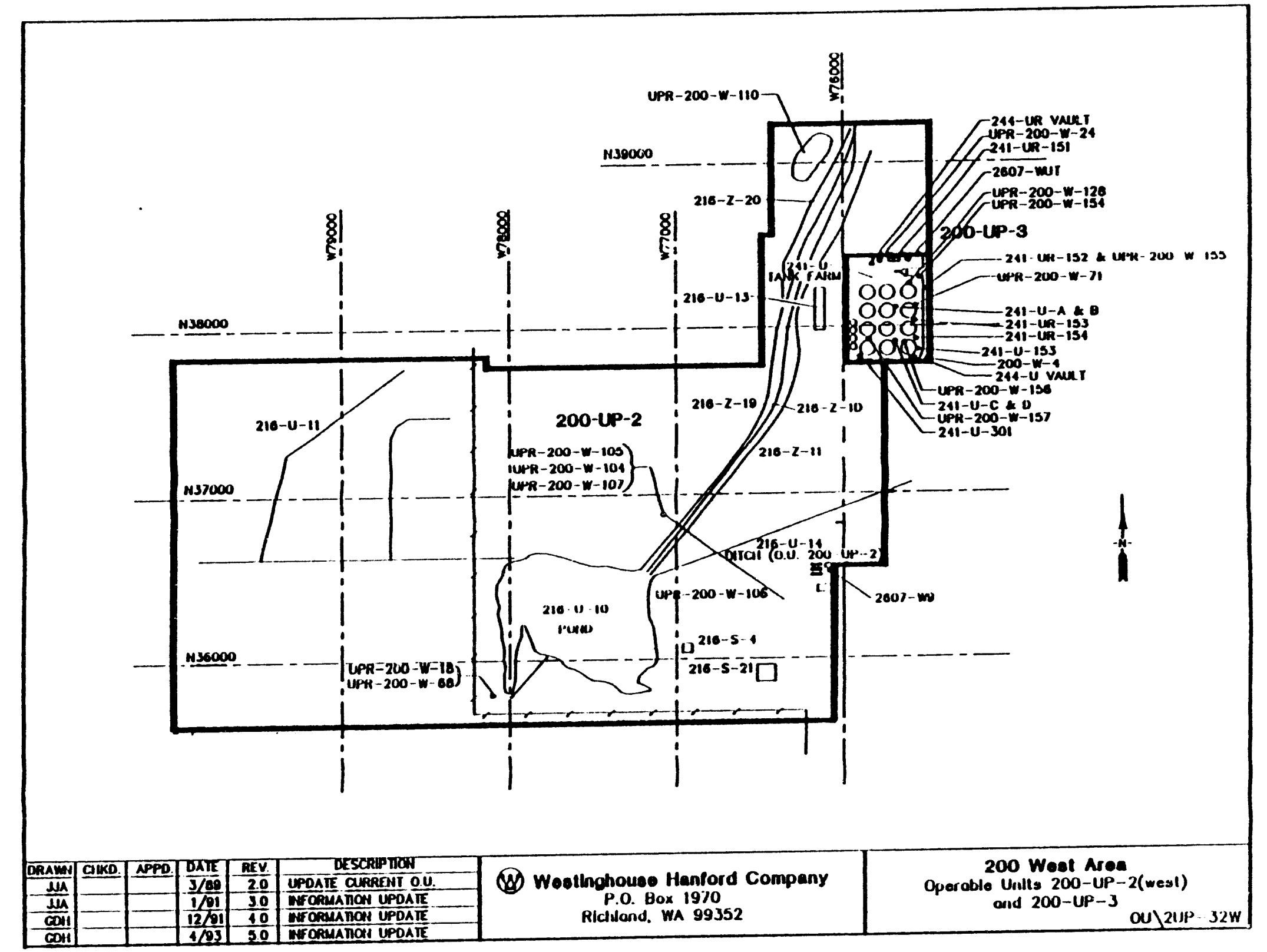




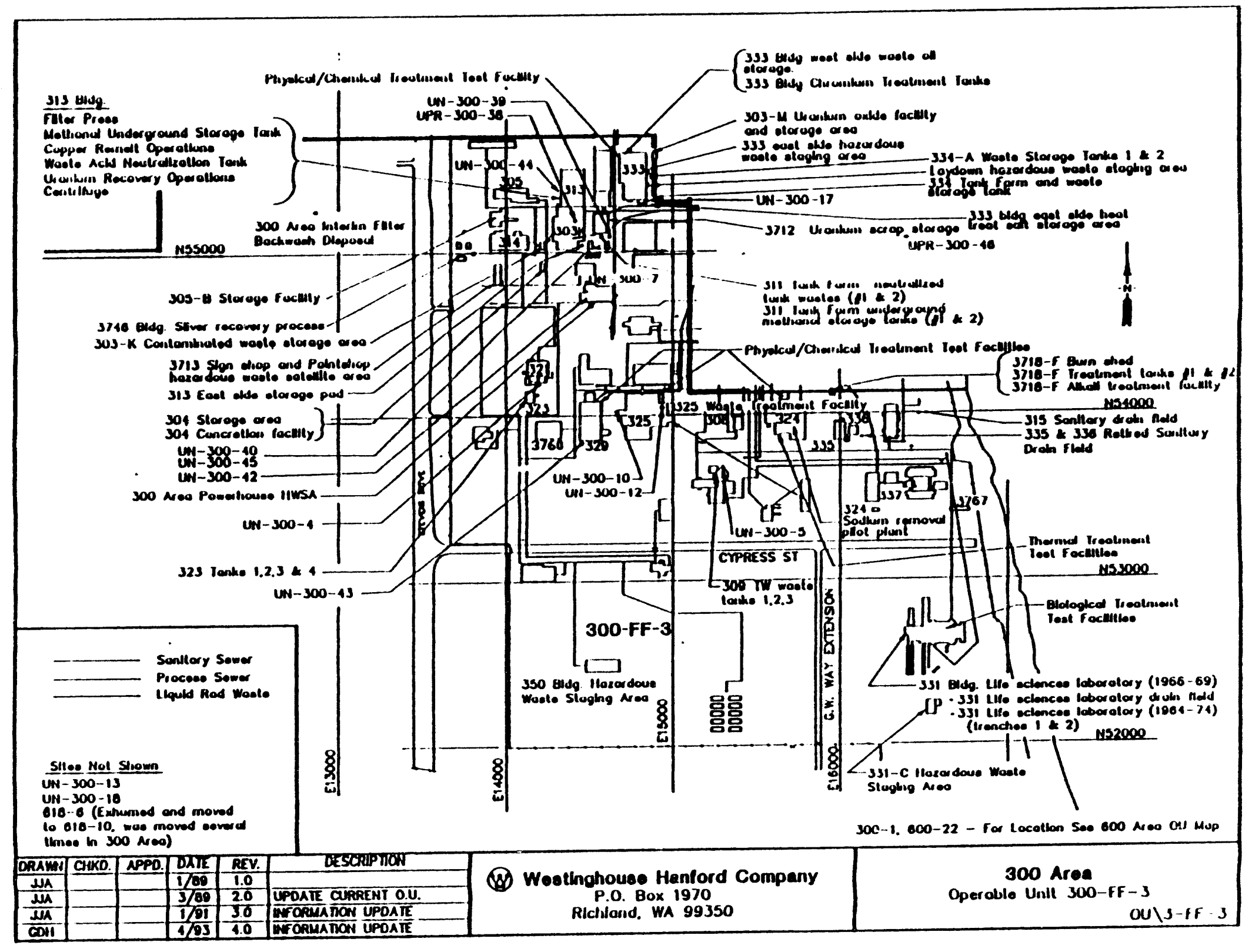




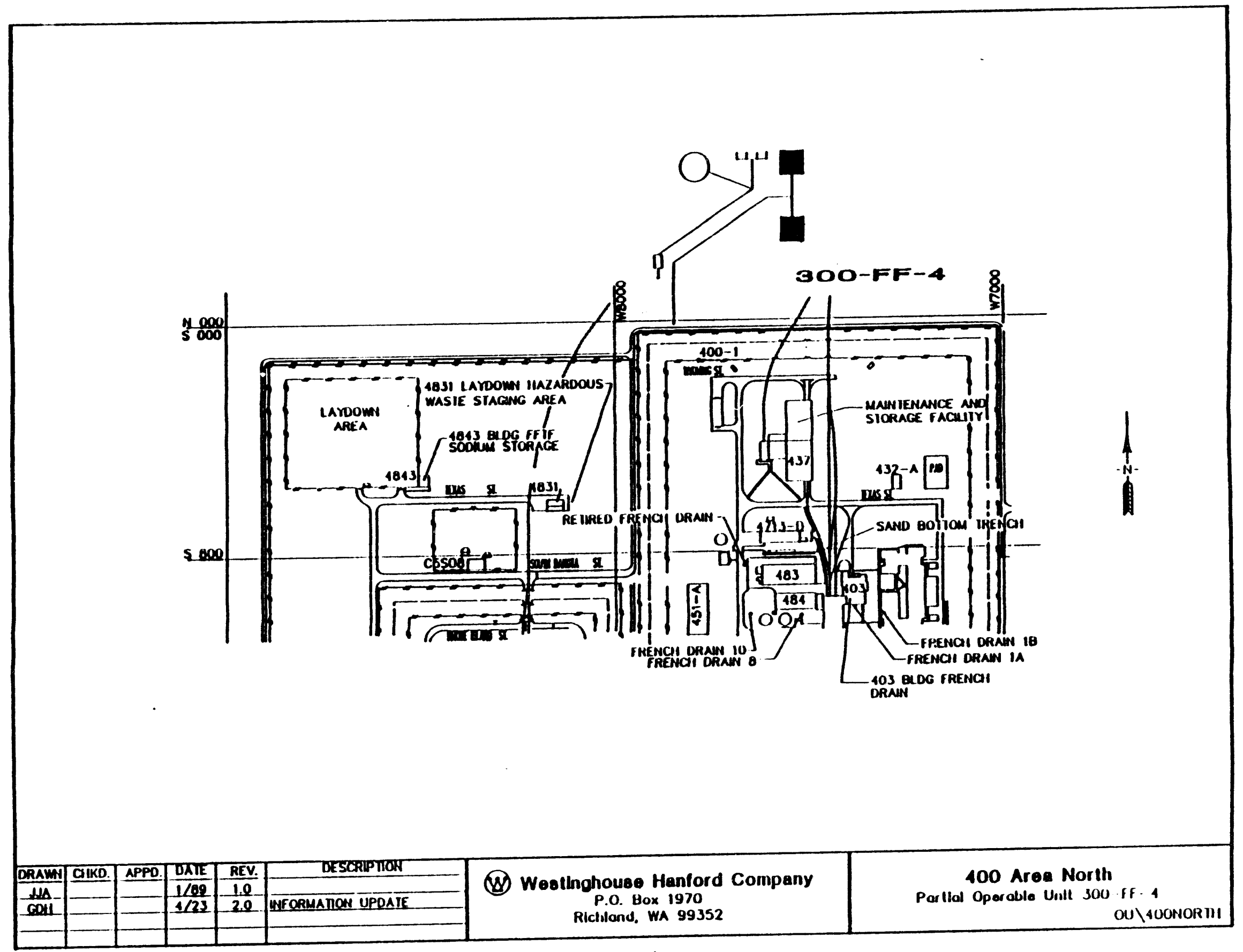




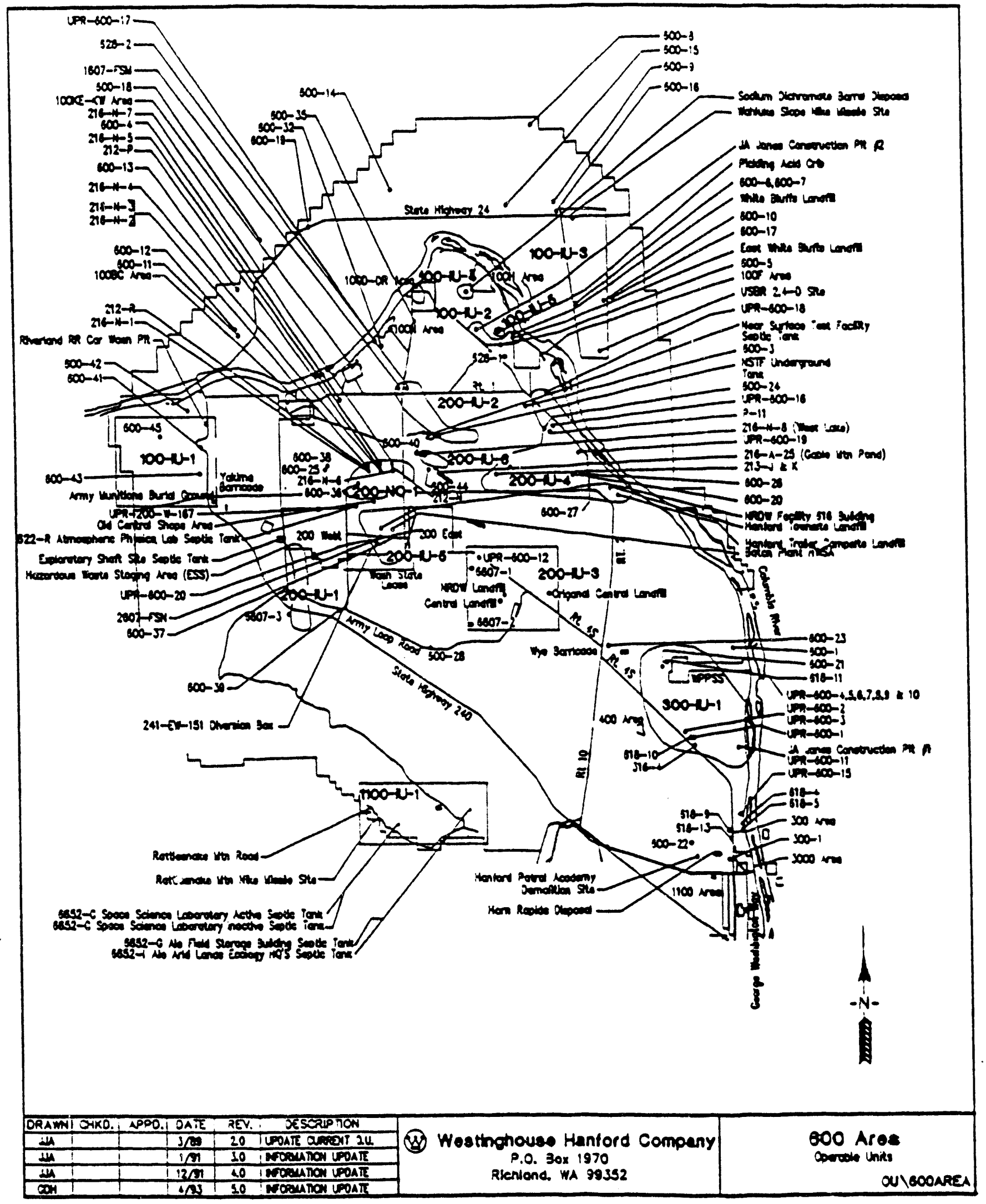


DOE/RL-91-28, Rev. 1

$05 / 28 / 93$

\section{APPENDIX 2B}

HANFORD FACILITY LEGAL DESCRIPTION 
DOE/RL-91-28, Rev. 1

$05 / 28 / 93$

This page intentionally left blank. 
DOE/RL-91-28, Rev. 1

$05 / 28 / 93$

\section{HANFORD FACILITY LEGAL DESCRIPTION}

2

3

The following legal description describes the overall facility boundaries of the DOE-RL controlled Hanford Site. Individual TSD units use only a very small portion of the Hanford Site. Additional descriptive information on the individual TSD units is contained in the Unit-Specific Portion of this permit application:

The Hanford Site being a tract of 1 and located in Benton County, WA, the aforesaid tract being more particularly described as follows:

Commencing at the point of intersection of the $E$. $-W$. centerline of sec. 14, T.10N., R.28E. Willamette Meridian, with the western navigation line of the Columbia River;

Thence northerly 200 feet along said line of navigation to the TRUE POINT OF BEGINNING;

Thence W. to a point on the W. right-of-way line of George Washington Way, which line is the boundary of the city of Richland;

Thence southerly 100 feet or less, along said right-of-way line of George Washington Way to a point on the N. right-of-way line of Horn Rapids Road, an unplatted road;

Thence $W$. along the $N$. right-of-way line of Horn Rapids Road approximately $1 / 2$ mile to the E. right-of-way line of Stevens Drive, an unplatted road;

Thence S. along said E. right-of-way line to a point on the N. right-ofway line of Spengler Street, a platted street;

Thence W. 145 feet to the W. right-of-way line of Stevens Drive;

Thence $S$. to a point 30 feet $N$. of the $S$. line of sec. 27, T.10N., R.28 E.W.M.;

Thence $W$. along a line 30 feet $N$. of, and parallel with, the $S$. line of sec. 27 to the E. line of the S.W. 1/4 of the S.E. 1/4 of said section;

Thence N. along the E. line of the S.W. 1/4 of the S.E. 1/4 of sec. 27 to the S.E. corner of the N.W. 1/4 of the S.E. 1/4 of said sec. 27;

Thence W. along the S. line of the N.W. $1 / 4$ of the S.E. $1 / 4$ to the W. 1 ine of the E. $1 / 2$ of sec. 27 ;

Thence $N$. along the $W$. line of the $E .1 / 2$ of $\mathrm{sec} .27$, and of the $E .1 / 2$ of sec. 22 and the E. $1 / 2$ of sec. 14 to the N. right-of-way line of Horn Rapids Road;

Thence westerly and northwesterly along the N. right-of-way line of Horn Rapids Road 26,000 feet more or less to the line's intersection with the $N$. right-of-way line of State Highway 240, in the N.E. 1/4 of sec. 11, T.10N., R.27E.W.M.;

Thence northwesterly along said N. right-of-way line of the highway, 75 feet $N$. of and parallel with the centerline of said highway to a point in sec. 3, T.10N., R.27E.W.M., which point is on the eastward extension of the N. right-of-way line of a county road from Horn Rapids to Benton City;

Thence along the northerly and westerly right-of-way line of said road, 75 feet northerly and westerly of, and parallel with, the center line of said road to a point on the E. line of sec. 8, T.1ON., R.27E.W.M.;

Thence $N$. to the $E$. quarter corner of said section; 
DOE/RL-91-28, Rev. 1

$05 / 28 / 93$

\title{
HANFORD FACILITY LEGAL DESCRIPTION (cont)
}

\author{
Thence W. to the S.W. corner of the E. $1 / 2$ of the N.E. $1 / 4$ of sec. 12 , \\ T.10N., R.26E.W.M.; \\ Thence $N$. to the $N$. line of said sec. 12; \\ Thence W. to the N.E. corner of the N.W. $1 / 4$ of the N.W. $1 / 4$ of the N.W. \\ $1 / 4$ of sec. 11, T.10N., R.26E.W.M.; \\ Thence S. 660 feet; \\ Thence W. 660 feet to the E. I ine of sec. 10, T.10N., R.26E.W.M.; \\ Thence S. to the S.E. quarter corner of said sec. 10; \\ Thence $W$. along the E. $-W$. centerline of sec. 10 to the $W$. line of said \\ section; \\ Thence $N$. along the $W$. section line to the S.E. corner of sec. 4, T.10N., \\ R.26E.W.M.; \\ Thence W. along the S. line of sec. 4 and sec. 5 to the S.W. corner of \\ the S.E. $1 / 4$ of the S.E. $1 / 4$ of sec. 5 ; \\ Thence N. to the S.E. corner of the N.W. $1 / 4$ of the S.E. $1 / 4$ of sec. 5 ; \\ Thence W. along the S. line of the N.W. $1 / 4$ of the S.E. 1/4 to the S.W. \\ corner of the N.W. $1 / 4$ of the S.E. 1/4;
}

Thence N. to the S.E. corner of the N. $1 / 2$ of the N.W. 1/4;

Thence W. along the S. line of the N. $1 / 2$ of the N.W. $1 / 4$ to the W. line of sec. 5;

Thence N. to the S.E. corner of sec. 31, T.11N., R.26E.W.M.;

Thence $W$. along the $S$. line of the E. $1 / 2$ of the S.E. $1 / 4$ of sec. 31 to the E. line of said E. $1 / 2$ of the S.E. $1 / 4$ of sec. 31;

Thence $N$. along the $W$. line of the E. $1 / 2$ of the S.E. $1 / 4$ to the S.E. corner of the S.W. $1 / 4$ of the N.E. $1 / 4$ of sec. 31 ;

Thence W. along the S. line of the S.W. $1 / 4$ of the N.E. $1 / 4$ to the S.W. corner of the S.W. $1 / 4$ of the N.E. $1 / 4$;

Thence N. along the W. line of the S.W. $1 / 4$ of the N.E. $1 / 4$ to the S.E. corner of the N. 1/2 of the N.W. 1/4 of said sec. 31 ;

Thence $W$. along the S. I ine of the N. 1/2 of the N.W. 1/4 to the W. Tine of said sec. 31 ;

Thence $N$. along the $W$. Iine of sec. 31 to the S.E. corner of sec. 25, T.11N., R.25E.W.M.;

Thence W. along the S. line of sec. 25 to the S.W. corner of the S.E. 1/4 of the S.E. $1 / 4$ of said sec. 25;

Thence N. along the W. line of the S.E. $1 / 4$ of the S.E. $1 / 4$ to the S.E. corner of the N.W. $1 / 4$ of the S.E. 1/4;

Thence W. along the S. line of the N.W. $1 / 4$ of the S.E. $1 / 4$ to the S.W. corner of the N.W. $1 / 4$ of the S.E. 1/4;

Thence N. along the W. line of the N.W. $1 / 4$ of the S.E. $1 / 4$ to the S.E. corner of the N.W. 1/4 of sec. 25; $\sec 25$;

Thence W. along the S. I ine of the N.W. $1 / 4$ of sec. 25 to the W. line of

Thence $N$. along the $W$. Tine of sec. 25 and the $W$. line of sec. 24 to the N. 1 ine of the $S .1 / 2$ of the S. $1 / 2$ of sec. 23 ;

Thence $W$. along the $N$. line of the $S .1 / 2$ of the $S .1 / 2$ of sec. 23 and the N. line of the S. $1 / 2$ of the S. $1 / 2$ of sec. 22 and the N. line of the $S$. $1 / 2$ of the $S .1 / 2$ of sec. 21 to the E. line of sec. 20; 
DOE/RL-91-28, Rev. 1

$05 / 28 / 93$

HANFORD FACILITY LEGAL DESCRIPTION (cont)

Thence S. to the S.E. corner of sec. 20;

Thence $W$. along the S. I ine of sec. 20 and the S. line of sec. 19 to the S.E. corner of the S.W. $1 / 4$ of the S.W. $1 / 4$ of sec. 19;

Thence N. to the N.E. corner of the S.W. 1/4 of the S.W. 1/4 of sec. 19;

Thence $W$. to the $W$. line of sec. 19, all being in T.11N., R.25E.W.M.;

Thence continuing $W$. to the S.W. corner of the N.E. $1 / 4$ of the S.E. 1/4 of sec. 24, T.11N., R.24E.W.M.;

Thence N. to the N.W. corner of said N.E. 1/4 of the S.E. $1 / 4$ of sec. 24;

Thence W. to the S.W. corner of the S.E. 1/4 of the N.W. 1/4 of sec. 24;

Thence N. to the N.W. corner of said S.E. 1/4 of the N.W. 1/4 of sec. 24;

Thence $W$. to the $W$. line of sec. 24;

Thence N. to the N.W. corner of sec. 24;

Thence $W$. to the S.E. quarter corner of sec. 14;

Thence N. to the N.W. quarter corner of sec. 14;

Thence $W$. along the $N$. line of sec. 14 to the N.W. corner of sec. 14;

Thence N. along the W. line of sec. 11 and sec. 2 to the N.W. corner of sec. 2, all being in T.11N., R.24E.W.M., and continuing N. along the W. lines of secs., 35, 26, 23, 14, 11, and 2 , all being in T.12N., R.24E.W.M.;

Thence continuing $N$. along the $W$. lines of secs. 35 and 26 in T.13N., R.24E.W.M., to the N.W. corner of sec. 26;

Thence $W$. along the S. line of sec. 22 to the S.E. quarter corner of sec. 22;

Thence N. along the N.-S. centerline of sec. 22 to the N.E. quarter corner of sec. 22;

Thence W. along the S. line of sec. 15 to the S.W. corner of sec. 15;

Thence N. along the W. line of sec. 15 to the S.W. corner of the N. $1 / 2$ of the N.W. $1 / 4$ of sec. 15;

Thence $E$. along the S. I ine of the N. $1 / 2$ of the N.W. $1 / 4$ of sec. 15 to

the S.W. corner of the N.W. $1 / 4$ of the N.E. $1 / 4$ of sec. 15;

Thence N. along the W. line of the S.W. $1 / 4$ of the N.E. $1 / 4$ of sec. 15 and continuing $N$. along the centerline of sec. 10 to the $W$. navigation line of the Columbia River, following said navigation line easterly, northerly, and southerly to a point directly $W$. of the $S$. line of Tract 4 of Ringold Tracts according to the plat filed in the records of Franklin County.

Thence southerly along the said $W$. line of navigation to the TRUE POINT OF BEGINNING.

EXCEPTING FROM THE ABOVE-DESCRIBED LAND THE FOLLOWING PARCELS, EXCLUDING that portion of the Hanford Railroad and any Hanford Site access roads which may traverse these parcels.:

PARCEL A) The N. $1 / 2$ of the N.W. 1/4, and that portion of the N.W. $1 / 4$ of the N.E. $1 / 4$ in sec. 14, T.13N., R.24E.W.M. in the ownership and jurisdiction of the BONNEVILLE POWER ADMINISTRATION.

PARCEL B) SEC. 1, T.1IN., R.26E.W.M. in the ownership under quitclaim deed, of the STATE OF WASHINGTON.

PARCEL C) A tract of land leased to the STATE OF WASHINGTON lying in sections 7, 8, and 9, T.12N., R.26E.W.M., containing 1,000 acres more or less, more particularly described as follows: That part of the S. $1 / 2$ of said sec.

7 bounded on the $W$. and $N$. by the following described line: BEGINNING at a 
DOE/RL-91-28, Rev. 1

$05 / 28 / 93$

HANFORD FACILITY LEGAL DESCRIPTION (cont)

1

2

3

4

5

point on the $S$. line of said sec. 7 , which point is S. $88^{\circ} 44^{\prime} 47^{\prime \prime} \mathrm{W} .4,515.30$ feet from the S.E. corner of the sec., and at coordinates N. 438,868.46 and E. $2,222,800.00$ on the Washington State Grid System, South Zone; thence $N$. 1,781.54 feet; thence E. 2,200.00 feet; thence N. 907.19 feet more or less to the N. line of said S. $1 / 2$ of the sec.; thence N. $88^{\circ} 38^{\prime} 43^{\prime \prime}$ E. along said line 2,275.48 feet more or less to the $E$. quarter corner of said sec. 7 . The $\mathrm{S} .1 / 2$ of sec. 8 . The S. $1 / 2$, and the S. $1 / 2$ of the N. $1 / 2$ of sec. 9, EXCEPT that portion lying easterly of the following described line: BEGINNING at a point on the E. line of said sec. 9, which point is N. $0^{\circ} 53^{\prime} 09^{\prime \prime} \mathrm{W} .3,071.71$ feet from the S.E. corner of the sec., and at coordinates N. 442,268.92 and E. $2,237,790.19$ on the Washington State Grid System, South Zone; thence northwesterly along a 1,055.37 foot radius curve to the right an arc distance of $1,064.64$ feet (the chord of said arc bears N. $30^{\circ} 21^{\prime} 08^{\prime \prime} W .1,020.05$ feet) to a point on the N. line of the S. 1/2 of the N. 1/2 of said sec. 9, said point being at coordinates N. 443,149.16 and E. 2,237,274.74 on the Washington State Grid Systen, South Zone.

Three tracts of land leased to the WASHINGTON PUBLIC POWER SUPPLY SYSTEM more particularly described as follows:

PARCEL D) a tract of 1 and (for the Hanford Generating Plant), commencing at the S.E. corner of sec. 28, T.14N., R.26E.W.M., said point having Washington State Coordinates, South Zone, of N. 486,994.01, and E. $2,236,672.11$; thence N. $72^{\circ} 02^{\prime} 15^{\prime \prime} \mathrm{W} .3,483.15$ feet, thence N. $67^{\circ} 11^{\prime} 41^{\prime \prime} \mathrm{W}$. 1,810 feet more or less to a point on the line of ordinary high water on the right bank of the Columbia River, which point is the TRUE POINT OF BEGINNING: thence S. $67^{\circ} 11^{\prime} 41^{\prime \prime}$ E. 1,810 feet more or less to a point, having Washington State Coordinates, South Zone, of N. 488,068.19 and E. 2,233,358.73, thence N. $22^{\circ} 48^{\prime} 19^{\prime \prime}$ E. a distance of 1,595 feet to a point, having Washington State Coordinates, South Zone, of N. 489,538.48 and E. 2,233,976.96, thence N. $67^{\circ}$ $11^{\prime} 41^{\prime \prime}$ W. 1,108 feet more or less to a point on the line of ordinary high water on the right bank of the Columbia River, thence southwesterly along the said line of ordinary high water to the TRUE POINT OF BEGINNING, containing 53.42 acres more or less; THIS PARCEL AMENDED BY DELETING THE FOLLOWING:

Beginning at the S.E. corner of the leased parcel, which point is at coordinates N. 488,068.19 and E. 2,233,358.73 on the Washington State Coordinate, South Zone; thence N. $22^{\circ} 48^{\prime} 19^{\prime \prime}$ E. 1,060 feet; thence N. $67^{\circ} 11^{\prime}$ $41^{\prime \prime}$ W. 200 feet; thence S. $22^{\circ} 48^{\prime} 19^{\prime \prime} \mathrm{W} .1,060$ feet; thence S. $67^{\circ} 11^{\prime} 41^{\prime \prime}$ E. 200 feet to the point of beginning; containing 4.85 acres, more or less;

PARCEL E) a tract of land (for WNP Site 2), beginning at the S.W. corner of sec. 11, T.11N., R.28E.W.M., said corner having Washington State coordinates, South Zone, of N. 408,335.30 and E. 2,307,653.50, thence N. $0^{\circ}$ $41^{\prime} 08^{\prime \prime}$ E. 8,065.28 feet to the TRUE POINT OF BEGINNING; thence W. $11,153.57$ feet; thence S. $01^{\circ} 01^{\prime} 23^{\prime \prime}$ E. 3,000.48 feet; thence S. $88^{\circ} 53^{\prime} 54^{\prime \prime} \mathrm{W}$. $5,200.96$ feet; thence N. $0^{\circ} 31$ ' 41" W. 3,690.15 feet; thence E. 1,430.00 feet; thence N. 1,865.69 feet; thence N. $87^{\circ} 46^{\prime} 08^{\prime \prime}$ E. 3,703.83 feet; thence S. $01^{\circ}$ $01^{\prime} 23^{\prime \prime}$ E. 1,600.25 feet; thence E. 11,189.29 feet; thence N. 01 $01^{\prime} 23^{\prime \prime}$ E. $1,800.29$ feet; thence N. $89^{\circ} 07^{\prime} 55^{\prime \prime}$ E. $3,300.38$ feet to the line of Navigation of the $W$. bank of the Columbia River, thence southerly along said line of Navigation to a point that bears $N .89^{\circ} 15^{\prime} 21^{\prime \prime} \mathrm{E}$. from the TRUE POINT 
$\mathrm{DOE} / \mathrm{RL}-91-28$, Rev. 1

$05 / 28 / 93$

HANFORD FACILITY LEGAL DESCRIPTION (cont)

OF BEGINNING; thence S. $89^{\circ} 15^{\prime} 21^{\prime \prime} \mathrm{W} .3,850.32$ feet more or less to the TRUE POINT OF BEGINNING.

PARCEL F) A tract of 1 and (for WNP Sites 1 and 4) lying in Section 4 of Township 11 North, Range 28 East, Willamette Meridian, described as follows:

Beginning at the Southwest corner of Section 11, Township 11 North, Range 28 East, W.M., (said corner being located by reference to the Washington State Coordinate jystem South Zone at coordinates North 408,335.30 and East $2,307,653.50$ ) thence North $65^{\circ}-17^{\prime}-03^{\prime \prime}$ West 12113.14 feet to the TRUE POINT OF BEGINNING (said point being located by reference to the Washington State Coordinate System South Zone at coordinates North 413,400.00 and East $2,296,650.00)$; thence North $01^{\circ}-01^{\prime}-23^{\prime \prime}$ West 3000.48 feet to a point; thence East 5280.00 feet to a point; thence South $01^{\circ}-01^{\prime}-23^{\prime \prime}$ East 3000.48 feet to a point; thence West 5280.00 feet more or less to the TRUE POINT OF BEGINNING, containing 363.69 acres more or less; and

A parcel of 1 and $7 y$ ing in Sections 3 and 4 of Township 11 North, Range 28 East, and Sections 33 and 34 of Township 12 North, Range 28 East, Willamette Meridian, described as follows:

Beginning at the Southwest corner of Section 11, Township 11 North, Range 28 East, W.M., (said corner being located by reference to the Washington State Coordinate System South Zone at coordinates North 408,335.30 and East $2,307,653.50$ ) thence North $50^{\circ}-42^{\prime}-00^{\prime \prime}$ West $14,311.63$ feet to the TRUE POINT OF BEGINNING (said point being located by reference to the Washington State Coordinate System South Zone at coordinates North 417,400.00 and East $2,296,578.57$ ); thence North $01^{\circ}-01^{\prime}-23^{\prime \prime}$ West 3000.48 feet to a point; thence East 5,280.00 feet to a point; thence South $01^{\circ}-01^{\prime}-23^{\prime \prime}$ East 1200.19 feet to a point; thence East 5,973.57 feet to a point; thence South $1^{\circ}-01^{\prime}-23^{\prime \prime}$ West 1800.29 feet to a point; thence West $11,189.29$ feet more or less to the TRUE POINT OF BEGINNING, containing 609.15 acres more or less.

PARCEL G) The parcels on the Hanford Site used but not owned by the Bonneville Power Administration including the Ashe Substation, the Hanford Substation, the Benton Switch Substation, and the White Bluffs Substation. ASHE SUBSTATION. A parcel of 1 and in the W. $1 / 2$ S.E. $1 / 4$, the S.E. $1 / 2$ N.W. $1 / 4$ and the S.W. $1 / 4$ of Section 32, Township 12 North, Range 28 East, Willamette Meridian, Benton County, Washington, more particularly described as follows:

Commencing at a Bonneville Power Administration monument set at the intersection of the north-south and east-west base lines for the Ashe Substation Site in the S.E. 1/4 S.W. 1/4 of Section 32, Township 12 North, Range 28 East, Willamette Meridian. This monument is iocated N.26 49'15'E., 1503.1 feet from a 2 -inch brass disc on the south line of Section 32, said disc being set by WPPSS survey of August 11,1971 . Thence N.52 $10^{\prime} 10^{\prime \prime E}$.,

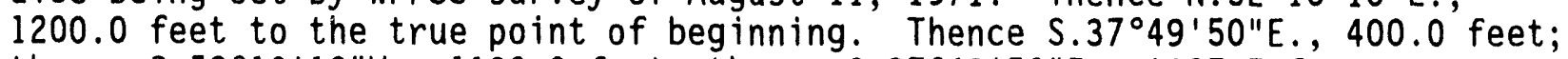

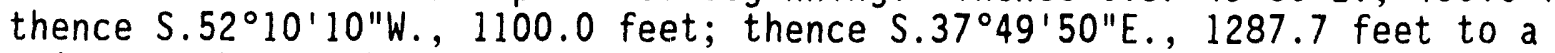
point on the south 1 ine of Section 32 ; thence $S .87^{\circ} 46^{\prime} 12^{\prime \prime} \mathrm{W}$., along said south line of Section 32, a distance of 984.0 feet; thence N.37 $49^{\prime} 50^{\prime \prime} \%$,

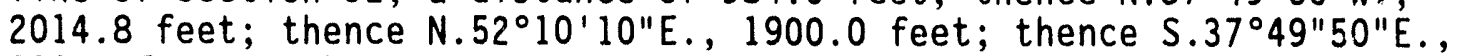
900.0 feet to the true point of beginning; containing 75.09 acres, more or less. 
DOE/RL-91-28, Rev. 1

$05 / 28 / 93$

HANFORD FACILITY LEGAL DESCRIPTION (cont)

ASHE SS SOUTH CORRIDOR, PARCEL 1. A portion of Government Lot 3 of Section 5, Township 11 North, Range 28 East, Willamette Meridian, Benton County, Washington, more particularly described as follows:

Commencing at a point in Bay 3 in the Ashe Substation Site in the N.E. 1/4 S.W. 1/4 of Section 32, Township 12 North, Range 28 East, Willamette

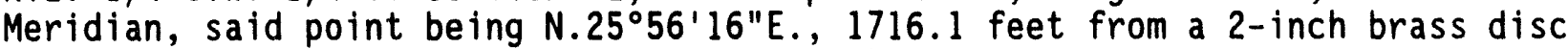
on the south line of Section 32, said disc being set by WPPSS survey of August 11,1971 . Thence $S .31^{\circ} 24^{\prime} 10^{\prime \prime} E ., 553.5$ feet; thence S.1 ${ }^{\circ} 50^{\prime} 00^{\prime \prime} \mathrm{E}$, 1029.6 feet to a point on the north 1 ine of Section 5, Township 11 North, Range 28 East, Willamette Meridian, the true point of beginning for this description. Thence N.87 $86^{\prime} 12^{\prime \prime} E$., along said north line of Section 5 , a distance of 75 feet; thence S.1 ${ }^{\circ} 50^{\prime} 00^{\prime \prime E}$., 1299.7 feet; thence $S .88^{\circ} 10^{\prime} 00^{\prime \prime} W$., 281.5 feet; thence N. $1^{\circ} 50^{\prime} 00^{\prime \prime W} ., 1297.6$ feet to a point on said north 1 ine; thence $N .87^{\circ} 46^{\prime} 12^{\prime \prime} E$., along said north line, a distance of 206.5 feet to the true point of beginning.

ASHE SS SOUTH CORRIDOR, PARCEL 2. A11 that portion of the S.E. 1/4 S.W. 1/4 of Section 32, Township 12 North, Range 28 East, Willamette Meridian, Benton County, Washington, that lies southerly and easterly of the Ashe Substation Site and westerly of a line 75 feet easterly from and parallel with the survey line for the Bonneville Poser Administration WPPSS No. 2 Powerhouse-Ashe $500 \mathrm{kV}$ line No. 2. The survey line is described, with reference to the Washington Coordinate System - South Zone, as follows:

Beginning at a point in Bay 3 in the Ashe Substation Site in the N.E. 1/4 S.W. $1 / 4$ of Section 32, Township 12 North, Range 28 East, Willamette Meridian, at a survey Station $97+84.0$, said point being N.25 $56^{\prime} 16^{\prime \prime}$ E., 1716.1 feet from a 2 -inch brass disc on the south line of Section 32, said disc being set by WPPSS survey of August 11,1971 . Thence S.31 $24^{\prime} 10^{\prime \prime E}$., 553.5 feet to station $92+30.5$; thence $S .1^{\circ} 50^{\prime} 00^{\prime \prime} E$., 1029.6 feet to a point on the south line of Section 32 , said point being N.87 $46^{\prime} 12^{\prime \prime E}$., 1072.1 feet from said brass disc.

ASHE-SS-AR-1. A portion of Lot 3 S.1/2 N.W. 1/4, and N.W. 1/4 S.W. $1 / 4$ of Section 5, the E. $1 / 2$ S.E. $1 / 4$ and S.W. $1 / 4$ S.E. $1 / 4$ of Section 6 , the N.W. $1 / 4$ N.E. $1 / 4$ and E. 1/2 N.W. $1 / 4$ of Section 7, Township 11 North, Range 28 East, Willamette Meridian, Benton County. Washington.

HANFORD SUBSTATION SITE. Lot I of Block 8 , Lots 13 and 14 of Block 9 , and Lot 8 of Block 10 of Hanford, according to the recorded plat thereof, and that part of Thirteenth Street lying between the northeasterly line of Tract $A$ of Hanford, according to the recorded plat thereof and the Columbia River, and that part of Dunham Street lying southeasterly of a line connecting the northwesterly lines of Lot 8 of Block 10 and Lot 13 of Block 9 of Hanford, according to the recorded plat thereof, all in Section 25, Township 13 North, Range 27 East, Willamette Meridian Benton County, Washington, containing 2.7 acres, more or less. Sub.ject to easement to Pacific Power \& Light Company for power line and access purposes.

BENTON SWITCH SUBSTATION. A parce 1 of 1 and in the N.W. $1 / 4$ of Section 11, Township 11 North, Range 28 East, Willamette Meridian, Benton County, Washington, described with reference to the Washington Coordinate System - South Zone, as follows: 
DOE/RL-91-28, Rev. 1

$05 / 28 / 93$

\section{HANFORD FACILITY LEGAL DESCRIPTION (cont)}

Beginning at the northwest corner of said parcel, being $S .54^{\circ} 50^{\prime} E$., 1804.0 feet more or less from the northwest corner of said Section 11; thence N. $49^{\circ} 13^{\prime} 45^{\prime \prime} E$., 550.0 feet to the northeast corner, evidenced by a brass cap; thence $S .40^{\circ} 46^{\prime} 15^{\prime \prime} E ., 500.0$ feet to the southeast corner, evidenced by a brass cap; thence $S .49^{\circ} 13^{\prime} 45^{\prime \prime} \mathrm{W}$., 550.0 feet to the southwest corner, evidenced by a brass cap; thence N. $40^{\circ} 46^{\prime} 15^{\prime \prime} \mathrm{W} ., 500.0$ feet to the point of beginning. The described parcel contains 6.31 acres, of which 2.75 acres 1 ie within the boundaries of the existing Benton Switching Station.

WHITE BLUFFS SUBSTATION. A parcel of 1 and in Government Lots 3 and 4 and the E. 1/2 S.W. 1/4 of Section 7, Township 10 North, Range 28 East, Willamette Meridian, Benton County, Washington, more particularly described as follows:

Commencing at a Bonneville Power Administration monument in said Government Lot 4 at the intersection of the east-west and north-south base lines for the White Bluffs Substation Site, said monument being N.36 $45^{\prime} 35^{\prime \prime} E$., 1623.7 feet from the southwest corner of Section 7 . This corner is evidenced by a rock mound. Thence $\mathrm{N} .72^{\circ} 55^{\prime} 20^{\prime \prime} \mathrm{W}$., along the east-west base 1 ine, a distance of 500 feet to the true point of beginning. Thence N.1 $7^{\circ} 04^{\prime} 40^{\prime \prime} E$., 400 feet; thence S. $72^{\circ} 55^{\prime} 20^{\prime \prime} E ., 900$ feet; thence S. $17^{\circ} 04^{\prime} 40^{\prime \prime} \mathrm{W} ., 1060$ feet, more or less, to a point 40 feet north of the centerline of Horn Rapids Road; thence $N .72^{\circ} 55^{\prime} 20^{\prime \prime W}$., 900 feet., thence $N .17^{\circ} 04^{\prime} 40^{\prime \prime} E$., 660 feet, more or less, to the true point of beginning, containing 21.90 acres, more or less.

For purposes of application of Part IV Corrective Action of the Hanford Facility Permit only, the Hanford Facility also includes PARCELS C, D, E, F, and $G$ of the lands identified as Excepted from the ABOVE-DESCRIBED LAND, in the foregoing legal description. 


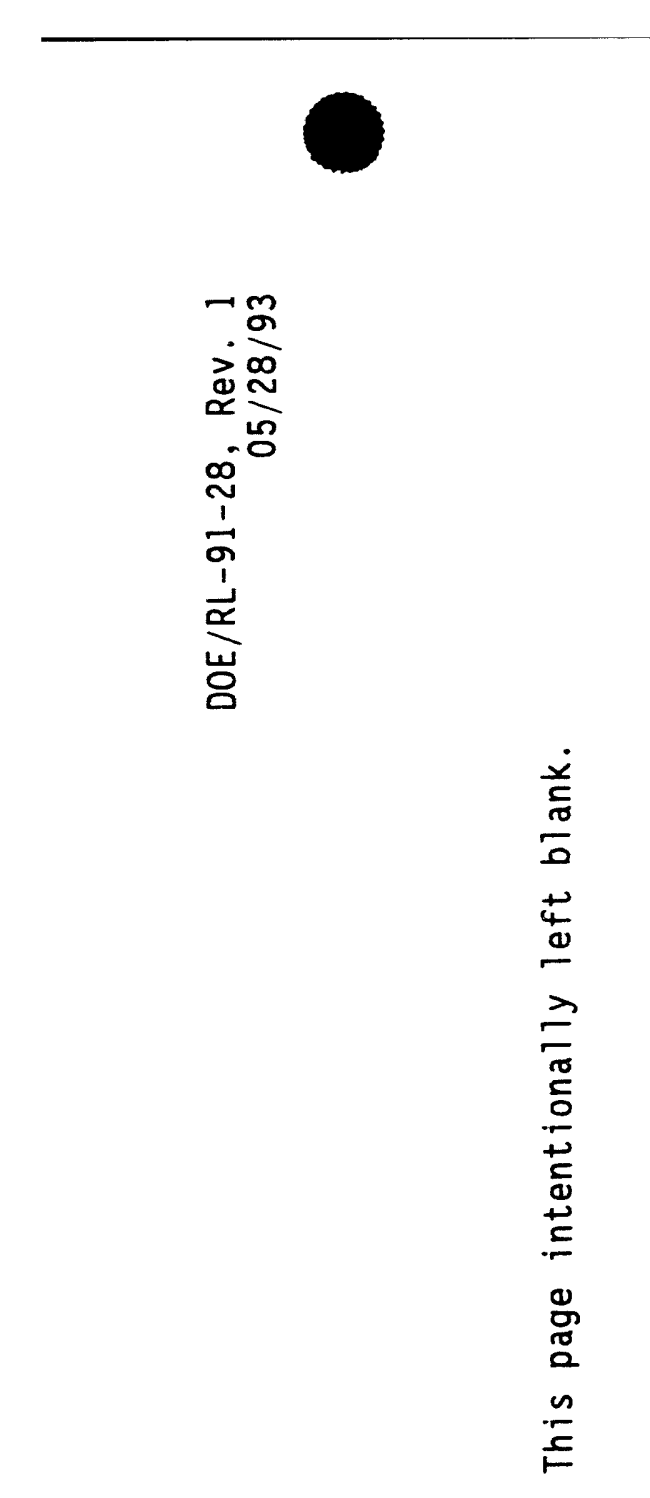

$\infty$
1
0
$⿱ 亠 乂$
0
$\vdots$ 
DOE/RL-91-28, Rev. 1 $05 / 28 / 93$

APPENDIX 7A

HANFORD FACILITY CONTINGENCY PLAN 
$\mathrm{DOE} / \mathrm{RL}-91-28$, Rev. 1

$05 / 28 / 93$

HANFORD FACILITY CONTINGENCY PLAN

CONTENTS

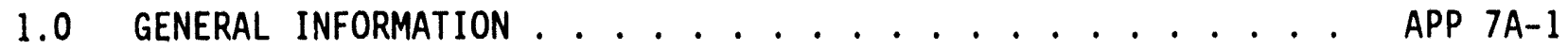

2.0 PURPOSE .............................. APP 7A-1

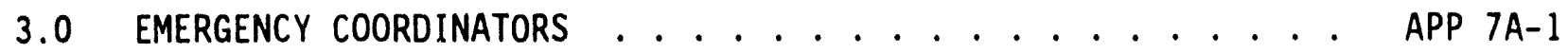

4.0 IMPLEMENTATION OF THE CONTINGENCY PLAN . . . . . . . APP 7A-2

5.0 INCIDENT RESPONSE . . .......... APP 7A-3

5.1 INCIDENT GENERIC RESPONSES .......... APP 7A-3

5.1 .1 Discoverer ............ . . APP 7A-3

5.1 .2 Single Point-of-Contact ........ APF 7A-4

5.1.3 Building Emergency Director (or al ternate) . . APP 7A-5

5.1.4 Identification of Hazardous Materials and Dangerous Waste and Assessment of Hazards

5.1.6 Protective Actions

5.2 RESPONSE TO MINOR SPILLS OR RELEASES $\because \cdots$ APP $7 A-7$

5.3 MAJOR DANGEROUS WASTE AND/OR MIXED WASTE SPILL

OR MATERIAL RELEASE . ............. APP 7 A-7

5.3.1 Discoverer . . . . . . . . . . . . APP 7A-8

5.3.2 Single Point-of-Contact .......... APP 7A-8

5.3.3 Building Emergency Director......... APP 7A-8

5.3.4 Hanford Fire Department Response to Major

or Unknown Spills . . . . . . . APP 7A-10

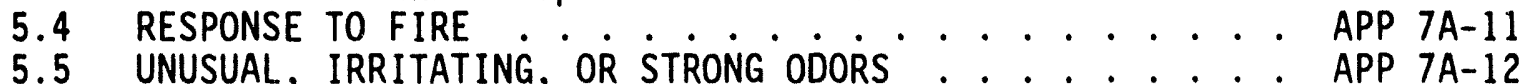

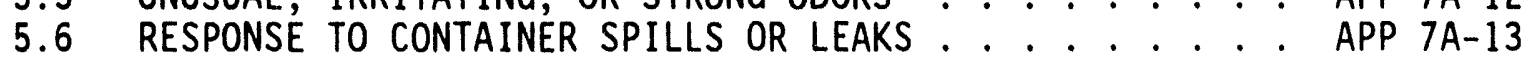

5.7 RESPONSE TO TRANSPORTATION AND/OR PACKAGING

INCIDENTS . . . . . . . . . . . . . . . . . APP 7A-13

5.7.1 Initial Responder Actions ......... APP 7A-13

5.7.2 Event Commander--Outside Treatment,

Storage, and/or Disposal Units ....... APP 7A-14

5.8 DAMAGED, UNACCEPTABLE SHIPMENTS ....... APP 7A-16

5.9 PREVENTION OF RECURRENCE OR SPREAD OF FIRES,

EXPLOSIONS, OR RELEASES ............ APP 7 A-17

6.0 TERMINATION OF EVENT, INCIDENT RECOVERY, AND RESTART OF

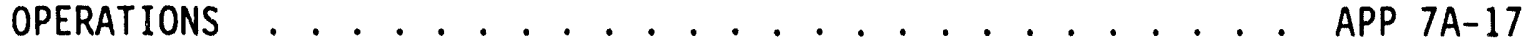

6.1 TERMINATION OF EVENT . . . . . . . . . . APP 7A-17

6.2 INCIDENT RECOVERY AND RESTART OF OPERATIONS . . . . . . APP 7A-18

6.3 INCOMPATIBLE WASTE . . . . . . . . . . APP 7A-18

6.4 POST-EMERGENCY EQUIPMENT MAINTENANCE AND

APP $7 A-19$ 
7.0 EMERGENCY CONTROL CENTERS, EMERGENCY EQUIPMENT . . . . . . . APP 7A-20

7.1 HANFORD FACILITY EMERGENCY CONTROL CENTERS . . . . . . APP 7A-20

7.2 COMMUNICATIONS EQUIPMENT .............. APP 7A-20

7.3 FIRE CONTROL EQUIPMENT ............. . APP 7A-20

7.4 PERSONAL PROTECTIVE EQUIPMENT . . . . . . . . . . . . APP 7A-20

7.5 SPILL CONTROL AND CONTAINMENT SUPPLIES ........ . . APP 7A-21

7.6 HANFORD SITE EMERGENCY ORGANIZATIONS . . . . . . . . . APP 7A-21

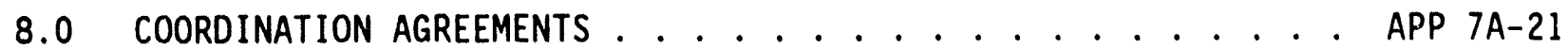

8.1 LOCAL, STATE, AND FEDERAL AUTHORITIES . . . . . . . . APP 7A-22

8.2 HANFORD FIRE DEPARTMENT MUTUAL AID . . . . . . . . . . APP 7A-22

8.3 MEDICAL AND FIRST AID . . . . . . . . . . . . . . APP 7A-22

8.4 AMBULANCE SERVICE ................... . . . APP 7A-22

8.5 UNIFIED DOSE ASSESSMENT CENTER . . . . . . . . . . . . . . APP 7A-23

8.6 HANFORD PATROL/BENTON COUNTY SHERIFF . . . . . . . . . APP 7A-23

8.7 ALERTING OF PERSONNEL ON THE COLUMBIA RIVER . . . . . APP 7A-23

8.8 METEOROLOGICAL INFORMATION ............. APP 7A-23

8.9 WASHINGTON PUBLIC POWER SUPPLY SYSTEM . . . . . . . . . APP 7A-24

9.0 REQUIRED REPORTS . . . . . . . . . . . . . . . . . . . . . . APP 7A-24

9.1 ASSESSMENT REPORT TO ECOLOGY AND GOVERNMENT

OFFICIAL OR NATIONAL RESPONSE CENTER . . . . . . . . APP 7A-24

9.2 WRITTEN REPORT TO ECOLOGY .............. . . APP 7A-24

9.3 OCCURRENCE REPORTING . . . . . . . . . . . . . . APP 7A-25

9.3.1 Emergency Event Reporting .. . . . . . . . APP 7A-25

9.3.2 Unusual Occurrence Reporting . . . . . . . APP 7A-26

9.3.3 Offnormal Event Reporting .......... APP 7A-26

10.0 CONTINGENCY PLAN LOCATION . . . . . . . . . . . . . APP 7A-26

\section{FIGURE}

1. Hanford Facility Evacuation Routes and Locations of the Fire Stations on the Hanford Facility........... APP 7A-F1 
$\mathrm{DOE} / \mathrm{RL}-91-28$, Rev. 1 $05 / 28 / 93$

TABLES

1. Emergency Control Centers................ APP 7A-T1

2. Hanford Facility Alarm Systems . . . . . . . . . . . APP 7A-T2

3. Fire Department Equipment List . . . . . . . . . . . . . APP 7A-T3

7 


\subsection{GENERAL INFORMATION}

The Hanford Facility is defined as a single Resource Conservation and Recovery Act (RCRA) of 1976 facility identified by the U.S. Environmental Protection Agency/State Identification Number WA7890008967 that consists of over 60 treatment, storage, and/or disposal (TSD) units conducting dangerous waste management activities. The Hanford Facility consists of the contiguous portion of the Hanford Site that contains these TSD units and, for the purposes of RCRA, is owned by the U.S. Government and operated by the U.S. Department of Energy, Richland Operations Office (excluding lands north and east of the Columbia River, river islands, lands owned or used by the Bonneville Power Administration, lands leased to the Washington Public Power Supply System, and lands owned by or leased to the state of Washington).

\subsection{PURPOSE}

The Hanford Facility Contingency Plan (PIan), together with each TSD unit-specific contingency plan, meets the WAC 173-303 requirements for a contingency plan. This Plan includes descriptions of responses to a nonradiological hazardous materials spill or release at Hanford Facility locations not covered by TSD unit-specific contingency plans or building emergency plans. This Plan includes descriptions of responses for spills or releases as a result of transportation activities, movement of materials, packaging, and storage of hazardous materials.

\subsection{EMERGENCY COORDINATORS}

The overall responsibility for implementation of this Plan lies with the building emergency director (BED) or their designated alternates. The BED has the responsibilities of the Emergency Coordinator as discussed in WAC 173-303-360 and is also the Event Commander. A list of all BEDs and alternates is maintained at various locations throughout the Hanford Facility, and these individuals can be reached 24 hours a day. The BEDs have the authority to commit all necessary resources (both equipment and personne1) to respond to any emergency. Additional responsibilities have been delegated to Hanford Fire Department personnel who are authorized to act for the BED when the BED is absent. These Hanford Fire Department personnel have the authority to commit all necessary resources (both equipment and personnel) to respond to any emergency. 


\begin{abstract}
Response by a BED (or an Emergency Coordinator) usually is obtained through the DOE-RL single point-of-contact* by dialing telephone number 811 or 373-3800 or 375-2400. The single point-of-contact has been designated as the contact point to mobilize a response to any Hanford Facility emergency. The single point-of-contact is available at all times and has the responsibility to initiate notifications to the BED or alternate to begin responses to emergencies, as well as to dispatch emergency responders (Hanford Fire Department, Hanford Patrol, or ambulance services). All emergency notifications to the BED, building managers, etc., can be made directly from the affected TSD unit or through the single point-of-contact.
\end{abstract}

The unit-specific DOE-RL technical contact responds to regulatory agency inquiries regarding this $\mathrm{Plan}$. The unit-specific DOE-RL technical contact is accessed by contacting $373-3800$ or $375-2400$.

\title{
4.0 IMPLEMENTATION OF THE CONTINGENCY PLAN
}

This Plan describes parallel decision flow paths for evaluating and classifying an incident. The U.S. Department of Energy (DOE) Orders and WAC 173-303-360 require incident classification. The definition of emergencies according to DOE Orders differs from the definition contained in WAC 173-303. Because of this, a dual incident classification decision path is necessary to meet both DOE Orders and WAC 173-303 requirements. Incident classification according to DOE Orders is described in this Plan for completeness only. The DOE Orders will not be used to evaluate whether an incident requires implementation of a contingency plan.

Implementation of a contingency plan will occur when a BED has determined that a release, a fire, or an explosion has occurred at the Hanford Facility that could threaten human health and the environment. A release is defined in WAC 173-303-040 within the definition of "discharge". An incident requiring evacuation of personnel or the summoning of emergency response units will not necessarily indicate that a contingency plan has been or will be implemented.

Any incident that poses a potential threat to human health and the environment discovered by TSD unit personnel requires immediate notification of the BED and the single point-of-contact, who then notifies the Hanford Fire Department. Personnel may respond, in accordance with the procedures described in TSD unit-specific contingency plans, before the arrival of the $B E D$, as long as such response is within their level of training. The Hanford Fire Department is contacted through the single point-of-contact on all incidents involving dangerous materials or mixed waste. 
DOE/RL-91-28, Rev. 1

$05 / 28 / 93$

\subsection{INCIDENT RESPONSE}

Incident response procedures have been established for each TSD unit. The initial response to any emergency will be to immediately protect the health and safety of persons in the immediate area. Identification of released material is essential to determine appropriate protective actions. Containment, treatment, and disposal assessment will be the secondary responses.

The following sections describe actions for personnel for several different types of incidents, including a generic response, that might occur on the Hanford Facility. Regardless of how an incident is classified, minimum onsite notification requirements exist to ensure that the appropriate organizations are contacted and that the incident is classified correctly.

\subsection{INCIDENT GENERIC RESPONSES}

Responses made by the discoverer, single point-of-contact, and the BED are discussed in the following sections. Identification of hazardous materials and dangerous waste and the assessment of hazards also are discussed.

\subsubsection{Discoverer}

The discoverer performs the following actions:

1. Immediately notifies potentially affected personnel (including the BED, if present, for a TSD unit incident) of the incident

2. Immediately notifies the single point-of-contact (811* or 375-2400) and provides all known information, if the information can be obtained without jeopardizing personnel safety, including the following:

- Name(s) of chemical(s) involved and amount(s) spilled, on fire, or otherwise involved, or threatened by, the incident

- Name and callback telephone number of person reporting the incident

*The DOE-RL and other contractor personnel are trained to notify the Hanford Emergency number (811 from onsite telephones and 375-2400 from 375 prefix telephones) for immediate dispatch of the Hanford Fire Department for fire, ambulance services, hazardous materials/mixed waste response, and for the Hanford Patrol. Hanford Patrol, who operates the 811 number, and Pacific Northwest Laboratory Security, who operates the 375-2400 number, notify other organizations and contractors to ensure appropriate actions are taken. 
- Location of incident (identify as closely as possible)

- Time incident began or was discovered

- Where the materials involved are going or might go, such as into secondary containment, under doors, through air ducts, etc.

- Source and cause, if known, of spill or discharge

- Name(s) of anyone contaminated or injured in connection with the incident

- Any corrective actions in progress

- Anyone else who the discoverer has contacted.

\subsubsection{Single Point-of-Contact}

The single point-of-contact performs the following actions:

1. Initiates notification to the BED, or one of the alternates if the BED cannot be reached iulmediately, to arrange immediate response to the incident

2. Requests immediate response from the Hanford Fire Department for fire, ambulance service, and/or hazardous material/mixed waste incidents as needed

3. Contacts the Hanford Patrol for traffic control and security measures, as needed, based on the report of the discoverer

4. Initiates notification to appropriate management of the spill or release incident

5. Supports the BED in providing further notification and coordination of response activities if needed

6. Activates or requests activation of the appropriate alarm signals (as required) for the affected building or affected 200, 300, 400, or 600 Areas, when the BED determines that protective actions are necessary

7. Notifies the emergency response organizations

8. Prompts the affected area emergency control centers (ECC) to activate if requested by the BED or other authorized persons

9. Prompts activation of the DOE-RL Emergency Action and Coordinating Team (EACT), if necessary, to recommend protective actions for areas outside the Hanford Facility. 


\subsubsection{Building Emergency Director (or alternate)}

The BED (or alternate) performs the following actions:

1. Sounds appropriate alarms to notify occupants

2. Notifies the single point-of-contact if additional support or an area evacuation is needed

3. Activates the building emergency response organization as necessary

4. Arranges for care of any injured employees

5. Requests the single point-of-contact to activate the appropriate ECC if required. Activation of the ECC should be done whenever technical assistance is required in evaluating a spill, when the emergency might affect neighboring buildings, or when otherwise deemed necessary by the BED

6. Provides for event notification in accordance with DOE Order 5000.3B and other established Hanford Facility procedures

7. Provides details of the event to appropriate management as the details become available.

\subsubsection{Identification of Hazardous Materials and Dangerous Waste and Assessment of Hazards}

The BED ensures that trained personnel identify the character, source, amount, and areal extent of the hazardous material or dangerous waste involved in the incident to the extent possible. Identification of waste can be made by visual inspection of involved containers; by sampling; by reference to inventory records, shipping manifests, or waste tracking forms; or by consulting with TSD unit operations personnel. Samples of materials involved in an emergency might be taken by qualified personnel and analyzed as appropriate.

Concurrently, the hazards that the incident poses to human health and the environment also must be assessed. The assessment must take into consideration the direct, indirect, immediate, and long-term effects of the incident. In addition to the information sources identified previously, the hazard assessment should include other sources such as material safety data sheet toxicity and health information, and results from any personnel monitoring examinations conducted at medical facilities. These are the types of tools that wi? aid in ascertaining the extent to which human health and the environment is threatened.

Upon activation, the ECC is available to assist the BED if needed. Possible assistance could include determining the extent of an emergency, identifying the hazards associated with the materials or waste involved in the 
DOE/RL-91-28, Rev. 1

$05 / 28 / 93$

incident, assisting in response to the incident, or coordinating the

mobilization of special equipment or supplies to the incident site.

If assessment of all available information does not yield a positive assessment of the danger posed by the incident, a worst-case condition will be presumed and appropriate protective actions will be initiated. The BED is responsible to initiate any protective actions.

\subsubsection{Incident $\mathrm{Classification}$}

After the assessment has been completed, the incident should be ready for classification. If not, the BED will take whatever means are necessary to obtain the information to complete the classification. The BED must classify the incident according to the DOE Order and contingency plan implementation criteria in this section.

1. DOE Order Incident Classification

There are three categories of incidents on the Hanford Facility: offnormal event, unusual occurrence, and emergency. Incidents are categorized based on degradation of TSD-unit safety systems and impact to other TSD units, employees, structures, public safety, and the environment. Incidents categorized as offnormal events and unusual occurrences are communicated as described in Section 9.0. Incidents categorized as an emergency are further classified into one of three emergency classes as required by DOE Orders. Incidents categorized as emergencies will prompt automatic activation of the appropriate ECCS.

\section{WAC 173-303 Incident Classification}

If the BED determines that the incident meets the criteria for a release, a fire, or an explosion that threatens human health and the environment, the BED notifies the ECC (if activated) or the Occurrence Notification Center (ONC) for notification to local authorities for evaluation and/or action. In addition, the BED, with assistance from the ONC and environmental compliance/protection personnel, must immediately (within 2 hours) notify Ecology, and either the government official designated as the on-scene coordinator or the National Response Center. The information included in the assessment report to these agencies is described in Section 9.0.

\subsubsection{Protective Actions}

Evacuation and take cover alarms and procedures are discussed as follows:

1. Evacuation (Signal: Steady siren). Each TSD unit has emergency procedures that include an evacuation plan identifying emergency signals and staging area locations. In the event a Hanford Facility 
evacuation is required, TSD unit personnel evacuate to their designated staging area, are accounted for, and receive directions on routes to take to safely evacuate the area. If the primary route is blocked by the emergency, personnel use alternate evacuation routes determined at the time of the event.

Evacuation routes for the Hanford Facility are shown on Figure 1. Specific routes will be determined at the time of the event based on event magnitude, location, and meteorology.

2. Take Cover (Signal: Wavering siren). In the event of a take cover alarm, personnel should go inside the nearest building, or remain inside, close all exterior doors, and regulate ventilation to meet building-specific requirements. Personnel secure all waste and classified documents.

\subsection{RESPONSE TO MINOR SPILLS OR RELEASES}

(Signal: None) The TSD unit personnel generally perform immediate cleanup of minor spills or releases using sorbents and emergency equipment. Personnel detecting such spills or releases contact the single point-ofcontact to notify of the detection of such spills or releases and to ensure notification of the BED and the Hanford Fire Department. Responses to spills or releases occurring within individual storage cells, structures, modules, etc., during routine handling and storage are contained in TSD unit-specific contingency plans. Response to minor spills generally does not require the implementation of the contingency plan.

A spill or release of hazardous material or dangerous waste is considered 'minor' if all of the following are true:

- The spill does not threaten the health and safety of personnel at the TSD unit, i.e., an evacuation is not necessary

- The spill is small in size (generally less than half of the immediately dangerous to 1 ife and health quantities identified in material safety data sheets)

- The composition of the material or waste is known or can be quickly determined from label, manifest, material safety data sheets, or disposal request information.

If one or more of the foregoing conditions are not met, responses are performed as outlined in Section 5.3. Notification of the spill or release is made as outlined in Section 5.1.

\subsection{MAJOR DANGEROUS WASTE AND/OR MIXED WASTE SPILL OR MATERIAL RELEASE} release.

(Signal: None) The following actions are taken in the event of a major 


\subsubsection{Discoverer}

The discover performs the following:

1. If within the TSD unit, notifies personnel (including BED) of discovery of spill or release by sounding the appropriate alarm, using the public address system, etc.

2. Initiates notifications to the Hanford Fire Department (and BED if necessary) by contacting the single point-of-contact and provides all known information, in accordance with Section 5.1.

3. Takes action to contain and/or to stop the spill if all of the following are true:

- Identity of the substance(s) involved is known

- Appropriate protective equipment and control/cleanup supplies are readily available

- Action(s) can be performed safely without assistance, or assistance is readily available from other trained TSD unit personnel.

If any of the above conditions are not met, or there is any doubt, the discoverer evacuates the area and remains outside, upwind of the TSD unit, pending the arrival of the BED. The discoverer remains available for consultation with the BED, Hanford Fire Department, or other emergency response personnel.

\subsubsection{Single Point-of-Contact}

The single point-of-contact performs the following:

1. Notifies the Hanford Fire Department and relays information received from the event scene

2. Initiates notification to the BED if the BED is not at the TSD unit

3. Remains available to support further notification and response activities if needed.

\subsubsection{Building Emergency Director}

The BED performs or arranges for the following:

1. Proceeds directly to the TSD unit to coordinate further activity and to establish a command post at a safe location 
2. Obtains all available information pertaining to the incident and determines if the incident requires implementation of the contingency plan

3. Determines need for assistance from agencies 1 isted in Section 8.0 and arranges for their mobilization and response through the single point-of--contact

4. Initiates the appropriate alarm if building or area evacuation is necessary

5. Arranges for care of any injured persons

6. Requests activation of the affected area ECC via the single pointof-contact if a threat to surrounding buildings or structures exists

7. Provides for event notification in accordance with Section 5.1

8. Maintains access control at the incident site by keeping unauthorized personnel and vehicles away from the area. Security personnel can be used to assist in site control if control of the boundary is difficult (e.g., repeated incursions). In deterinining controlled access areas, considers environmental factors such as wind velocity and direction

9. Arranges for proper remediation of the incident after evaluation

10. Remains available for fire, patrol, and other authorities on the scene and provides all required information

11. Enlists the assistance of alternate $B E D(s)$ if around-the-clock work is anticipated

12. Refers media inquiries to the Media Relations/Communications offices of the contractors or the DOE-RL

13. Ensures the use of proper protective equipment, remedial techniques (including ignition source control for flammable spills), and decontamination procedures by all involved personnel if remediation is performed by TSD unit personnel. Areas of expertise are available in determining necessary equipment or procedures

14. Remains at the scene to oversee activities and to provide information if remediation is performed by the Hanford Fire Department Hazardous Materials Response Team or other response teams

15. Ensures proper containerization, packaging, and labeling of recovered spill materials and overpacked containers

16. Ensures decontamination (or restocking) and restoration of emergency equipment used in the spill remediation before resuming TSD unit operations 
17. Provides required reports after the incident in accordance with Section 9.0.

\subsubsection{Hanford Fire Department Response to Major or Unknown Spills}

The Hanford Fire Department response to unknown spills is as follows.

1. Initial Hanford Fire Department response includes one engine company, one hazardous materials unit, one ambulance unit, and one battalion commander.

2. The Hanford Fire Department, as the Hazardous Materials Incident Command Agency, establishes command and control of the situation. The first arriving unit assumes incident command and determines location of the command post, and evacuates personnel from a red zone consisting of a minimum of 100 feet ( 30.5 meters) in all directions. The red zone could be adjusted as deemed necessary by the hazardous materials team leader.

3. The Incident Commander evacuates all personnel within the red zone area.

4. The hazardous materials team leader establishes a yellow zone and decontamination corridor.

5. The hazardous materials team leader assigns fully trained and qualified team members specific tasks, i.e.,

Team Safety Officer : Decontamination Team Leader

Entry Team

Resource Leader

Backup Team

Science Leader

6. The hazardous materials team safety leader controls and directs the medical evaluations for personnel working in the red and the yellow zones.

7. Team members performing entry, back up, and decontamination, suit up in level "A" protection.

8. The entry team members make entry to obtain samples of unknown hazardous material, and observe for other pertinent information.

9. Entry team collects sample and exits area going through decontamination by decontamination team.

10. The hazardous materials sample is analyzed on scene by hazardous materials team personnel using available testing equipment. This testing is to determine hazard group classification, i.e., poison, acid, flammable, oxidizer, etc. 
11. Once the hazard classification has been identified, the hazardous materials entry team makes re-entry to stabilize and control hazardous materials to the point that the emergency no longer exists.

12. The entry team exits the area going through decontamination by the decontamination team.

13. The spill site is turned over to cleanup personnel for cleanup and disposal.

14. The hazardous materials response command is dissolved; all units return to stations.

15. A critique of the hazardous materials incident is held with team members as soon as possible after Hanford Fire Department units have returned to their stations.

\subsection{RESPONSE TO FIRE}

(Signal: Gong) In the event of a fire, the discoverer activates a fire alarm and calls the single point-of-contact. Automatic initiation of a fire alarm (through the smoke detectors and sprinkler systems) also is possible. The TSD unit personnel are trained in the use of portable fire extinguishers for incipient fires. Personnel use their best judgment whether to fight a fire or to evacuate. Under no circumstances do personnel remain to fight a fire if unusual hazards exist.

The following actions are taken in the event of a fire or explosion.

1. On actuation of the fire alarm, personnel shut down equipment, secure waste, and lock up classified documents (or carry the documents with them), ONLY if time permits. The alarm automatically signals the Hanford Fire Department and the Hanford Patrol Operations Center.

2. Personnel leave the area/building by the nearest safe exit and proceed to the designated staging area for accounting.*

3. The single point-of-contact is notified immediately, who in turn initiates notifications to the BED (or alternate) if necessary.

4. The BED proceeds directly to the scene (if not already there).

5. The BED obtains all necessary information pertaining to the incident.

* Nuclear or nuclear reactor facilities are not required to evacuate upon sound of a fire alarm but are provided supplemental information via building notification systems relative to evacuations. 
6. Depending on the severity of the event, the BED (or lead TSD unit manager) contacts the ONC and requests additional notifications to offsite agencies (e.g., Ecology, local counties, and COEHeadquarters), informing them as to the extent of the emergency (including estimates of dangerous waste or mixed waste quantities released to the environment) and any actions necessary to protect nearby buildings and/or structures.

7. Depending on the severity, the BED requests activation of the affected area ECC to establish organizations to provide assistance from the DOE-RL, other Hanford Facility contractors, and outside agencies.

8. The Hanford Patrol establishes roadblocks within the area to route traffic away from the emergency scene.

9. Hanford Fire Department medical personnel remove injured personnel to a safe location, apply first aid, and prepare the injured for transport to medical aid stations or to local hospitals in accordance with established memoranda of understanding (MOUs) (copies of the MOUs are maintained by the Hanford Fire Department). Medical personnel are on standby at the fire stations 24 hours a day.

10. Hanford Fire Department firefighters extinguish the fire.

11. All emergency equipment is cleaned and fit for its intended use following completion of cleanup procedures.

\subsection{UNUSUAL, IRRITATING, OR STRONG ODORS}

(Signa1: None) If an unusual, irritating, or strong odor is detected, and the discoverer has reason to believe that the odor might be the result of an uncontrolled release of a toxic or dangerous material, the discoverer performs the following:

- Activates the building evacuation alarm or fire alarm system to evacuate the building

- Notifies the single point-of-contact, the building manager, and cognizant line management.

If the discoverer knows of the source and scope of the release, this information is reported quickly to the BED. Measures are taken to contain the release and ventilate the area, if safe and advisable to do so.

If an unusual odor is detected within the building or structure, and the source of the odor is unknown, the BED considers additional protective actions. 
DOE/RL-91-28, ReV. 1

$05 / 28 / 93$

\subsection{RESPONSE TO CONTAINER SPILLS OR LEAKS}

In addition to the foregoing Plan provisions, the following specific actions could be taken for leaks or spills from containers at TSD units. These actions may be taken only by appropriately trained personnel.

- Container leaks are stopped as soon as possible using appropriate procedures. Appropriate personnel protective equipment is used.

- If it is inadvisable to approach the container, absorbent materials are used, and access is restricted pending notification of the BED and implementation of the Plan.

- Contents of leaking containers could be transferred to appropriate nonleaking containers. Transfer procedures for fire safety are followed for ignitable or reactive waste (e.g., use of nonsparking tools, bonding and grounding of containers, isolation of ignition sources, and use of explosion-proof electrical equipment).

- Overpacked containers are marked and labeled in the same manner as the contents. All containers of spill debris, recovered product, etc., are managed in the same manner as waste containers received from outside the TSD unit. Overpacks in use at the TSD unit are marked with information pertaining to their contents and noted as to whether the container inside the overpack is leaking or is in good condition.

\subsection{RESPONSE TO TRANSPORTATION AND/OR PACKAGING INCIDENTS}

This section describes the actions taken in the event of an unplanned sudden or nonsudden release of dangerous waste or dangerous waste constituents to air, soil, surface water, or groundwater during onsite transportation activities, or at locations not covered by a unit-specific contingency plan. This includes spills or releases as a result of transportation activities, movement of materials, packaging, and storage of hazardous materials.

The following actions are performed by those individuals responding to a hazardous materials transportation incident at the Hanford Facility.

\subsubsection{Initial Responder Actions}

The initial responder or discoverer of a hazardous materials spill or release resulting from onsite transportation activities initiates the following response actions, if the actions can be performed without jeopardizing personnel safety, as appropriate:

- Determines the nature of incident

- Personnel injuries

- Hazardous material spill with fire

- Hazardous material spill without fire. 
DOE/RL-91-28, Rev. 1

$05 / 28 / 93$

2

- Assists injured personne1

- Initiates notifications to the single point-of-contact by any means available (telephone, radio, passing motorist, etc.) to request assistance from the Hanford Fire Department (Emergency Coordinator for these type of events), Hanford Patrol, and medical personnel

- Remains in a safe location and attempts to isolate the area to prevent inadvertent personnel access.

\subsubsection{Event Commander--Outside Treatment, Storage, and/or Disposal Units}

If the emergency event is located within the responsibility of a BED, the BED will establish event command.

The Hanford Fire Department will establish and maintain incident command on arrival at the emergency event. The Incident Commander will perform or coordinate the event command actions for locations not controlled by a BED.

The Event Commander ensures that the cause of the incident and its possible effects are investigated and evaluated as soon as possible. The Event Commander, with input from the Incident Commander, assesses possible hazards to human health and the environment (considering direct, indirect, immediate, and long-term effects) that might result from the release, fire, or explosion and takes the following actions as appropriate:

- Isolate event from employees:

- Cordon off access

- Place apparatus to block roadways

- Use Hanford Patrol roadblocks

- Use TSD unit/vehicle public address systems

- Sound appropriate alarms.

- Determine type of hazardous materials involved:

- Occupancy/location

- Container shapes

- Markings and colors

- Placards and labels

- Shipping papers

- Consult reference materials [(U.S. Department of Transportation, National Institute of Occupational Safety and Health Pocket Guide to Chemical Hazards (NIOSH 1993)]

- Unit managers/employees.

- Notify the appropriate manager of the incident and ensure that the incident is reported properly in accordance with Section 9.0 of this Plan 
- If the TSD unit stops operations in response to a fire, an explosion, or a release, the BED will monitor for leaks, pressure buildup, gas generation, or ruptures in valves, pipes, or other equipment, wherever this is appropriate

- Coordinate with emergency response organizations to establish a command post, upwind and uphill of the incident:

- Ensure command post is located so as to minimize the need for relocation

- Direct incoming response vehicles to a safe staging area

- Coordinate tasks with other responders

- Activate required emergency centers

- Dispatch radiological and nonradiological field teams to help define and locate the plume.

- Ensure that all personnel who enter the area are equipped with proper protective clothing and respiratory protection

- Rescue should only be attempted when the risks have been evaluated and are considered acceptable

- If the risks are unknown, or considered unacceptable, wait for the Hazardous Materials Response Team.

Rescue/evacuation can be performed by trained personnel, other than the Hanford Fire Department, if the victim's location could present an immediate life-threatening situation or further injuries to the victim.

- Complete othe including but

is necessary to effect control of the scene, mited to the following:

NOTE: The following steps normally are conducted and/or directed by a Hanford Fire Department Hazardous Materials Response Team leader:

- Secure the scene

- Use absorbents

- Use covering (blankets, polyethylene, etc.)

- Overpack

- Plug/patch

- Transfer to new container

- Venting/vapor suppression.

- Initiate other measures as needed, including but not limited to, the following:

- Place hose streams and unmanned monitors

- Establish confinement dikes to prevent run-off

- Perform first aid.

- Obtain additional information:

- Who is operating the equipment

- What and how much hazardous material is involved

- Manufacturer, shipper, receiver

- Weather conditions. 
DOE/RL-91-28, Rev. 1

\subsection{DAMAGED, UNACCEPTABLE SHIPMENTS}

(Signal: None) When a damaged shipment of hazardous material or dangerous waste arrives at a TSD unit and the shipment is unacceptable for receipt, tre damaged shipment should not be moved. The TSD unit personnel instead perform the following steps.

- If the release from the damaged package is a 'minor' spill under the criteria of Section 5.2, the following actions are performed:

- Notify the BED, the Hanford Fire Department, and the single pointof-contact to advise of the situation. The BED responds and assists in the evaluation of, and response to, the incident

- Notify the generating unit of the damaged shipment and provide any chemical information necessary to assist in responding to the 'minor' spill

- Proceed with remedial action, including overpacking damaged containers, cleanup of spilled material, or other necessary actions to contain the spill. 
DOE/RL-91-28, Rev. 1

$05 / 28 / 93$

- Implement the TSD unit contingency plan, if the release does not meet the criteria of a 'minor' spill as noted previously, or the extent of the spill cannot be determined.

\subsection{PREVENTION OF RECURRENCE OR SPREAD OF FIRES, EXPLOSIONS, OR RELEASES}

The BED, in coordination with emergency response organizations, takes the steps necessary to ensure that a secondary release, fire, or explosion does not occur. The following actions are taken:

- Isolate the area of the initial incident by shutting off power, closing off ventilation systems, etc., to minimize the spread of a release and/or the potential for a fire or explosion

- Inspect containment for leaks, cracks, or other damage

- Inspect for toxic vapor generation

- Remove released material and waste remaining inside of containment structures as soon as possible

- Contain and isolate residual waste material using dikes and adsorbents

- Cover or otherwise stabilize areas where residual released materials remain to prevent migration or spread from wind or precipitation run-off

- Install new structures, systems, or equipment to enable better management of hazardous materials or dangerous waste

- Reactivate adjacent operations in affected areas only after cleanup of residual waste materials is achieved.

\subsection{TERMINATION OF EVENT, INCIDENT RECOVERY, AND RESTART OF OPERATIONS}

Information concerning termination of event, incident recovery, and restart of operations is provided in the following sections.

\subsection{TERMINATION OF EVENT}

It is a function of the BED (Emergency Coordinator) to declare the termination of an event. However, in an event where additional emergency centers are activated only the highest activated level of the emergency organization, in conjunction with the BED, will declare that an event has ended. If the DOE-RL-EACT is activated, only the DOE-RL director officially terminates the eveni. In all cases, however, the BED or Emergency Coordinator must be consulted before reentry is initiated. 
1

\subsection{INCIDENT RECOVERY AND RESTART OF OPERATIONS}

A recovery plan is developed when necessary. A recovery $p l a n$ is needed following an event when further risk could be introduced to persorinel, a TSD unit, or the environment through recovery action and/or to maximize the preservation of evidence. If a recovery $\mathrm{plan}$ is required, it is reviewed by appropriate personnel and approved before restart. Restart of operations is performed in accordance with the approved plan.

If the contingency plan was implemented, notification must be made to Ecology before operations can be resumed. Section 9.0 discusses different reports to outside agencies. This notification is in addition to the required reports in Section 9.0. This notification must include assurances that there are no incomp atibility issues with the waste and released materials from the incident, and that all the equipment has been cleaned, fit for its intended use, and placed back into service. The notification can be made via telephone conference. Any additional information that Ecology requests regarding these restart conditions could be included in the required 15-day report identified in Section 9.2.

For emergencies not involving activation of the ECC, the BED ensures that conditions are restored to normal before operations are resumed. If the ECC was activated and the emergency phase is complete, a special recovery organization could be appointed at the discretion of the BED to restore conditions to normal. The makeup of this organization depends on the extent of the damage and its effects. The recovery organization will be appointed by the appropriate contractors' emergency director.

\subsection{INCOMPATIBLE WASTE}

After an event, the BED or the recovery organization ensures that no waste that might be incompatible with the released material is treated, stored, and/or disposed of until cleanup is completed. Cleanup actions are taken by TSD unit operations personnel or other assigned personnel. Actions to be taken might include, but are not limited to, any of the following:

- Neutralization of corrosive spills

- Chemical treatment of reactive materials to reduce hazards

- Overpacking or transfer of contents from leaking containers

- Use of sorbents to contain and/or absorb leaking liquids for containerization and disposal

- Decontamination of solid suriaces impacted by released material, e.g., intact containers, equipment, floors, containment systems, etc.

- Disposal of contaminated porous materials that cannot be decontaminated and any contaminated soil 
- Containerization and sampling of recovered materials for classification and determination of proper disposal technique

- Follow up sampling of decontaminated surfaces to determine adequacy of cleanup techniques as appropriate.

Waste from cleanup activities is designated and managed as newly generated waste. A field check for compatibility before storage is performed as necessary. Incompatible waste is not placed in the same container. Containers of waste are placed in storage areas appropriate for their compatibility class.

If it is determined that incompatibility of waste was a factor in the incident, the BED or the recovery organization ensures that the cause is corrected. Examples would be modification of an incompatibility chart or increased scrutiny of waste from a generating unit when incorrectly designated waste caused or contributed to an incident.

\subsection{POST-EMERGENCY EQUIPMENT MAINTENANCE AND DECONTAMINATION}

All equipment used during an incident is decontaminated (if practicable) or disposed of as spill debris. Decontaminated equipment is checked for proper operation before storage for subsequent use. Consumables and disposed materials are restocked. Fire extinguishers are recharged or replaced.

The BED ensures that all equipment is cleaned and fit for its intended use before operations are resumed. Depleted stocks of neutralizing and absorbing materials are replenished, self-contained breathing apparatus are cleaned and refilled, and protective clothing are cleaned or disposed of and restocked, etc.

Equipment and personnel decontamination stations are established. Items to consider when establishing a decontamination station are as follows:

- Water supplies

- Containment/catch basins and/or systems

- Staff necessary to accomplish proper decontamination

- Protective clothing

- Decontamination supplies (buckets, brushes, soap, chemicals as needed)

- Risk to personnel

- Weather conditions; i.e., severe heat, cold (current and forecasted)

- Toxicity of material

- Porosity of equipment to be decontaminated

- Disposal requirements of decontamination rinse

- Use of controlled zones to maintain contamination control. 
DOE/RL-91-28, Rev. 1

\subsection{EMERGENCY CONTROL CENTERS, EMERGENCY EQUIPMENT, AND EMERGENCY ORGANIZATIONS}

Hanford Facility ECCS, emergency equipment, and emergency organizations are discussed in the following sections.

\subsection{HANFORD FACILITY EMERGENCY CONTROL CENTERS}

The ECCs are those locations staffed to provide assistance to building emergency organizations in an emergency situation. The ECCs are established to support and to provide overall direction of emergency events occurring at locations within their geographic area of responsibility, within the Hanford Facility. This includes acquisition of and assignment of resources to respond to emergency events. Responsibilities also include personnel protection (employee and public), TSD unit safety, and environmental protection. The establishment of ECCs ensures that notification and communication of emergency conditions are communicated properly.

There are five ECCS located throughout the Hanford Facility and Hanford Site (Table 1).

\subsection{COMMUNICATIONS EQUIPMENT}

The Hanford Facility has alarm systems that are monitored by the Hanford Fire Department and the Hanford Patrol Operations Center. The alarm signals that exist at the Hanford Facility are identified in Table 2. The TSD unit operations personnel also can use telephones, building public address systems, portable radios, and cellular telephones to summon assistance.

\subsection{FIRE CONTROL EQUIPMENT}

Many Hanford Facility buildings are equipped with automatic firesuppression (sprinkler) systems. Portable fire extinguishers are located in working areas in compliance with National Fire Protection Association safety codes. Each Class $A B C$ extinguisher is capable of suppressing fires involving ordinary combustible materials, flammable liquids, oils, paints, flammable gases, and electrical equipment. All extinguishers comply with the National Fire Code standards for portable extinguishers and are inspected monthly. The inspections are recorded on tags attached to each extinguisher.

\subsection{PERSONAL PROTECTIVE EQUIPMENT}

The TSD units have safety showers and eyewash stations, located as necessary, for personnel protection. Drainage from these stations is contained. In addition to these stations, portable eyewash equipment is maintained at protective storage areas as necessary. These eyewash/shower stations are inspected regulariy. 


\begin{abstract}
Protective clothing and respiratory protective equipment are maintained for use during both routine and emergency operations. This equipment is identified in the unit-specific contingency plans.

\subsection{SPILL CONTROL AND CONTAINMENT SUPPLIES}

Supplies of absorbent pillows are located in operating areas as necessary. These pillo:ds absorb organic or inorganic materials and have a rated absorption capacity of approximately 0.26 gallon (1 1 iter) of waste each. Absorbents might be used for barriers to contain liquid spills as well as for absorbent purposes. Diatomaceous earth for absorption of liquid waste spills is available. Neutralizing absorbent is available for response to acid or caustic spills. A supply of empty containers (U.S. Department of Transportation 17E tight head and U.S. Department of Transportation $17 \mathrm{H}$ open head) and salvage containers (overpacks) also are maintained, as well as brooms, shovels, and miscellaneous spill response supplies.
\end{abstract}

\title{
7.6 HANFORD SITE EMERGENCY ORGANIZATIONS
}

The Hanford Facility has fire and patrol personnel trained and equipped to respond in emergency situations. The Hanford Fire Department is the Hazardous Materials Incident Command Agency for the Hanford Site and has a Hazardous Materials Response Team that is trained to stabilize and control hazardous materials emergencies. A description of equipment for hazardous materials responses available through the Hazardous Materials Response Team is given in Table 3 . Locations of the four fire stations on the Hanford Facility are shown on Figure 1.

The Hanford Patrol provides support to the Hanford Fire Department during an incident, including such activities as activation of area crash alarm telephone systems or area sirens (for evacuation or take cover), access control, traffic control, and assistance in emergency notifications.

\subsection{COORDINATION AGREEMENTS}

This section describes a number of coordination agreements, or memoranda of understanding (MOU) established by and through the DOE-RL to ensure proper response resource availability for incidents involving the Hanford Facility.

An agreement among the four major Hanford Site contractors (an operations and engineering contractor, a research and development contractor, an engineer and constructor contractor, and a medical and health services contractor) dofines the interfaces and notifications required during an emergency. The DOE-RL has the overall responsibility for emergency preparedness. Per the agreements, the operations and engineering contractor has responsibility for Site-wide emergency preparedness while each contractor retains responsibility for emergency prepa! edriess at individual units. Agreements have been 
established with a number of offsite authorities to reduce the impact to human health and the environment in the event that an incident has offsite public health implications, or if an onsite emergency warrants offsite assistance. These agreements are activated through the emergency notification of the DOE-RL (Section 4.1).

\subsection{LOCAL, STATE, AND FEDERAL AUTHORITIES}

Various agreements have been established among the DOE-RL and Benton, Franklin, and Grant Counties and the states of Washington and Oregon. These agreements describe the cooperative arrangements among these agencies for any onsite emergency that warrants offsite assistance. These agreements describe the planning for, communication of, and response to emergencies at the Hanford Facility that might have offsite consequences.

\subsection{HANFORD FIRE DEPARTMENT MUTUAL AID}

The Hanford Fire Department provides fire department services for the Hanford Site and Hanford Facility. Mutual aid agreements have been established with the Richland, Kennewick, and Pasco fire departments; with Benton County Fire Districts 1 through 6, Franklin County Fire District 3, and Walla Walla Fire District 5.

\subsection{MEDICAL AND FIRST AID}

Professional medical help is provided onsite by the DOE-RL through the Hanford Environmental Health Foundation. Doctors and nurses are available for emergency assistance at all times. These medical personnel are trained in procedures to assist personnel contaminated with hazardous and/or radioactive material. Emergency call lists are maintained to provide professional medical consultation at all times.

Referral to offsite hospital facilities is made by the Hanford Environmental Health Foundation physician providing emergency assistance by telephone or in person. The primary hospital used in emergencies is Kadlec Hospital, Richland. Kennewick General Hospital, Kennewick, and Our Lady of Lourdes Hospital, Pasco, are used as backup facilities. Agreements have been established among these hospitals and the DOE-RL.

\subsection{AMBULANCE SERVICE}

Ambulance service is provided by the Hanford Fire Department, which uses paramedics and emergency medical technicians as attendants. This service is available from area fire stations on a 24-hour, 7-day basis. Additional ambulance service is available from other local city fire departments through the mutual aid agreements (Section 8.2). 


\subsection{UNIFIED DOSE ASSESSMENT CENTER}

The Unified Dose Assessment Center (UDAC) is the technical extension of the DOE-RL-EACT, providing services to both the DOE-RL-EACT and the ECC. The primary mission of the UDAC is to provide recommendations for protective actions, dose calculations and projections, and consultation in the area of industrial hygiene for hazardous materials, biology, environmental monitoring, and meteorology to support the DOE-RL-EACT and the ECC.

Industrial hygiene and biological consultants at the UDAC advise and assist in determining proper response procedures for spills or releases of toxic, flammable, carcinogenic, and pathogenic materials. The UDAC personnel are responsible to provide a central unified assessment of the dispersion and impact of environmental releases from the Hanford Facility. In communication with the ECC, the UDAC coordinates the assessment of impacts and assists in the determination of actual and potential release scenarios.

\subsection{HANFORD PATROL/BENTON C.OUNTY SHERIFF}

The Hanford Patrol serves as the security agency for the Hanford Facility. The Benton County Sheriff's Department provides law enforcement for the Hanford Facility. In the event of an emergency, the Hanford Patrol provides services such as activating the crash alarm systems or area sirens, coordinating the movement of emergency responders through security gates, assisting evacuation, establishing barricades, and making necessary notifications through the single point-of-contacts. Benton County Deputies will assist with traffic control activities. Agreements also have been established with the Richland, Kennewick, and Pasco police departments to provide additional backup capabilities if required.

\subsection{ALERTING OF PERSONNEL ON THE COLUMBIA RIVER}

An agreement exists among the JOE-RL, the Washington Public Power Supply System, Benton and Franklin Counties, and the Thirteenth Coast Guard District to ensure safety on the Columbia River during an emergency at the Hanford Facility and to coordinate response activities for alerting personnel on the Columbia River.

\subsection{METEOROLOGICAL INFORMATION}

An agreement is in place between the DOE-RL and the National Weather Service to define mutual responsibilities for providing meteorological information in an emergency situation. Additional meteorological information can be obtained from the Hanford Site Meteorological Station. 


\subsection{WASHINGTON PUBLIC POWER SUPPLY SYSTEM}

An agreement has been established between the DOE-RL and Washington Public Power Supply System for providing mutual assistance as needed. This assistance is available in the use of facilities and equipment for personnel decontamination, first aid, evacuation and reassembly areas, respiratory protective equipment, protective clothing, radiological survey equipment, resources for river evacuation, and radiological assistance response.

\subsection{REQUIRED REPORTS}

Three types of written post-incident reports are required for incidents at the Hanford Facility. These reports are summarized in the following sections.

\subsection{ASSESSMENT REPORT TO ECOLOGY AND GOVERNMENT OFFICIAL OR NATIONAL RESPONSE CENTER}

Immediately following classification of an incident as a WAC 173-303 emergency, as assessment report must be transmitted when the regulatory agencies are notified. This initial assessment report will be submitted by DOE-RL and must include:

- Name and telephone number of reporter

- Name and address of the Hanford Facility/TSD unit

- Time and type of incident

- Name and quantity of material(s) involved to the extent known

- Extent of injuries if any

- Possible hazards to human health and the environment outside the Hanford Facility.

\subsection{WRITTEN REPORT TO ECOLOGY}

Following an incident that requires implementation of the contingency plan, the BED must ensure that the time, date, and details of tile incident are recorded in the operating record. Within 15 day of the incident, a written report must be submitted to Ecology. The report generated through the DOE-RL reporting system may be used to supplement this written report, but will not bo used as a substitute. The 15 day report will be submitted by DOE-RL and mist include: 
DOE/RL-91-28, Rev. 1

$05 / 28 / 93$

- Name, address, and telephone number of the owner or operator

- Name, address, and telephone number of the Hanford Facility/TSD unit

- Date, time, and type of incident

- Name and quantity of material(s) involved

- Extent of injuries if any

- Assessment of actual or potential hazards to human health and the environment where this is applicable

- Estimated quantity and disposition of recovered material that resulted from the incident

- Cause of incident

- Descripticn of corrective action taken to prevent recurrence of the incident.

\subsection{OCCURRENCE REPORTING}

Under DOE Order 5000.3B, an occurrence report is required for incidents occurring at the Hanford Facility involving hazardous materials release, fire, or explosion. Specific details of this reporting system are found in the DOE Order. To summarize, the event is categorized within 2 hours and proper notifications are completed to onsite and offsite agencies to include contractor, DOE, county, and state organizations.

These occurrences are investigated, reported, and analyzed promptly to ensure that effective corrective actions are taken in compliance with contractual and statutory requirements. All such occurrences are recorded in the building manager's $10 \mathrm{~g}$ book, and the $10 \mathrm{~g}$ book is audited to ensure that incidents were reported and handled properly. In the DOE reporting system, three levels of incidents are described, in descending order of severity: emergency, unusual occurrence, and offnormal occurrences.

\subsubsection{Emergency Event Reporting}

An emergency event involves an incident in progress, or having occurred, that is the most serious occurrence and requires an increased alert status for onsite and, in specified cases, for offsite authorities. There are three classifications associated with emergency events: Alert, Site Area Emergency, and General Emergency. Occurrences are classified into one of the three levels based on real or potential consequences to personnel, facilities, or the environment, both on and off the Hanford Facility. Current MOUs between the state of Washington and the Hanford Site identify events that would be classified at the stated levels. Emergency events require notification of classification to affected populations. 


\subsubsection{Unusual Occurrence Reporting}

An unusual occurrence is a nonemergency occurrence that has significant impact or potential for impact on safety, environment, health, security, or operations. Generally, these types of events result in release of radioactive or hazardous materials in minor amounts, involve degradation of unit safety systems; and/or result in fatalities, exposures to hazardous or radioactive materials, or significant contamination incidents.

\subsubsection{Offnormal Event Reporting}

An offnormal event is a significant deviation from normal operations that requires categorization and reporting. Hanford Facility management is required to evaluate an event to determine the depth of investigation and level of reporting required.

\subsection{CONTINGENCY PLAN LOCATION}

Copies of this Plan are maintained at the following locations:

- Each specific TSD unit

- Hanford Fire Department (area fire stations)

- Area ECCS

- ONC

- The DOE-RL ECC, Federal Building, Richland. 
DOE/RL-91-28, Rev. 1

$05 / 28 / 93$

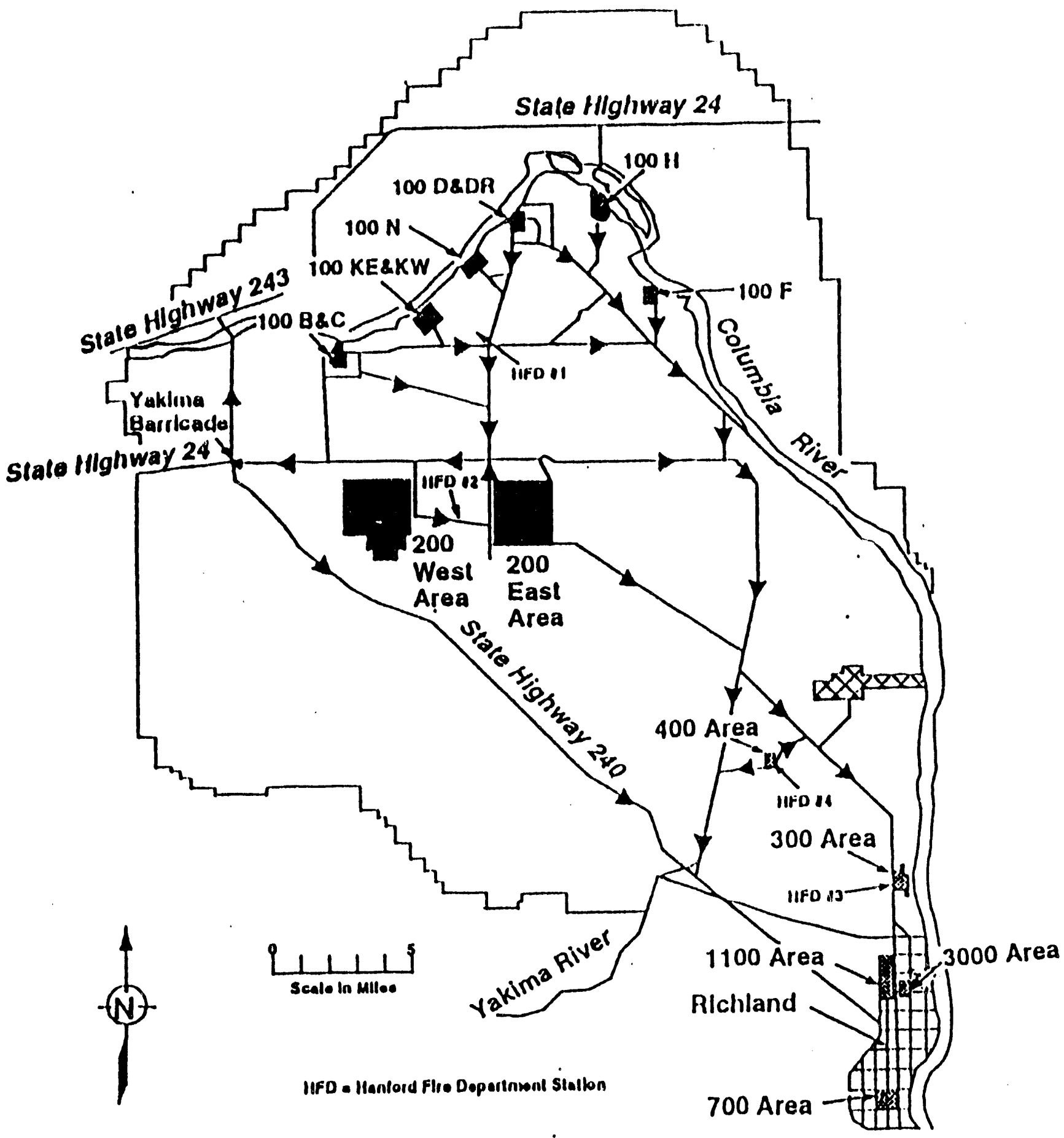

29209007.1

Figure 1. Hanford Facility Evacuation Routes and Locations of the Fire Stations on the Hanford Facility. 
Table 1. Emergency Control Centers.

\begin{tabular}{|c|c|}
\hline Emergency Control Center & Responsibility \\
\hline $\begin{array}{l}\text { Northern Area Emergency Control Center } \\
\text { Location: } 2750-E, 200 \text { East Area }\end{array}$ & $\begin{array}{l}\text { Geographic area of responsibility: } \\
\text { A11 } 100 \text { and } 200 \text { Areas plus the } \\
600 \text { Area north of the } \\
\text { WYE Barricade bounded by the } \\
\text { Columbia River and Highway } 240 \text {. }\end{array}$ \\
\hline $\begin{array}{l}300 \text { Area Emergency Control Center } \\
\text { Location: } 3701-D, 300 \text { Area }\end{array}$ & $\begin{array}{l}\text { Geographic area of responsibility: } \\
\text { RCHS, RCHC, RCHN, } 1100 \text { and } \\
3000 \text { Areas plus the } 600 \text { Area south } \\
\text { of the WYE Barricade bounded by } \\
\text { the Columbia River and Highway } \\
240 \text {. }\end{array}$ \\
\hline $\begin{array}{l}400 \text { Area Emergency Control Center } \\
\text { Location: Fast Flux Test Facility, } \\
400 \text { Area }\end{array}$ & $\begin{array}{l}\text { Geographic area of responsibility: } \\
400 \text { Area. }\end{array}$ \\
\hline $\begin{array}{l}\text { Emergency Management Center } \\
\text { Location: } 1170 \text { Building }\end{array}$ & $\begin{array}{l}\text { Area of responsibility: } \\
\text { Responsible for the remaining } \\
600 \text { Area not covered by the area } \\
\text { ECCs, assisting area ECCs, } \\
\text { coordinating the Facility-wide } \\
\text { response to emergencies, and } \\
\text { serving as the focal point for } \\
\text { other Hanford Site contractors and } \\
\text { DOE-RL during emergencies. }\end{array}$ \\
\hline $\begin{array}{l}\text { DOE-RL Emergency Control Center } \\
\text { Location: Federal Building, } \\
\text { Richland }\end{array}$ & $\begin{array}{l}\text { Area of responsibility: } \\
\text { Responsible for providing overall } \\
\text { direction for all Hanford Facility } \\
\text { emergency situations involving the } \\
\text { DOE-RL and/or contractor } \\
\text { personnel, ensuring direct } \\
\text { interface with all offsite } \\
\text { agencies for mitigation and } \\
\text { protection of offsite populations, } \\
\text { facilities, and the environment. }\end{array}$ \\
\hline
\end{tabular}

$$
\begin{aligned}
& \text { RCHS = Richl and South. } \\
& \text { RCHC }=\text { Richl and Central } . \\
& \text { RCHN }=\text { Richl and North. }
\end{aligned}
$$


DOE/RL-91-28, Rev. 1

$05 / 28 / 93$

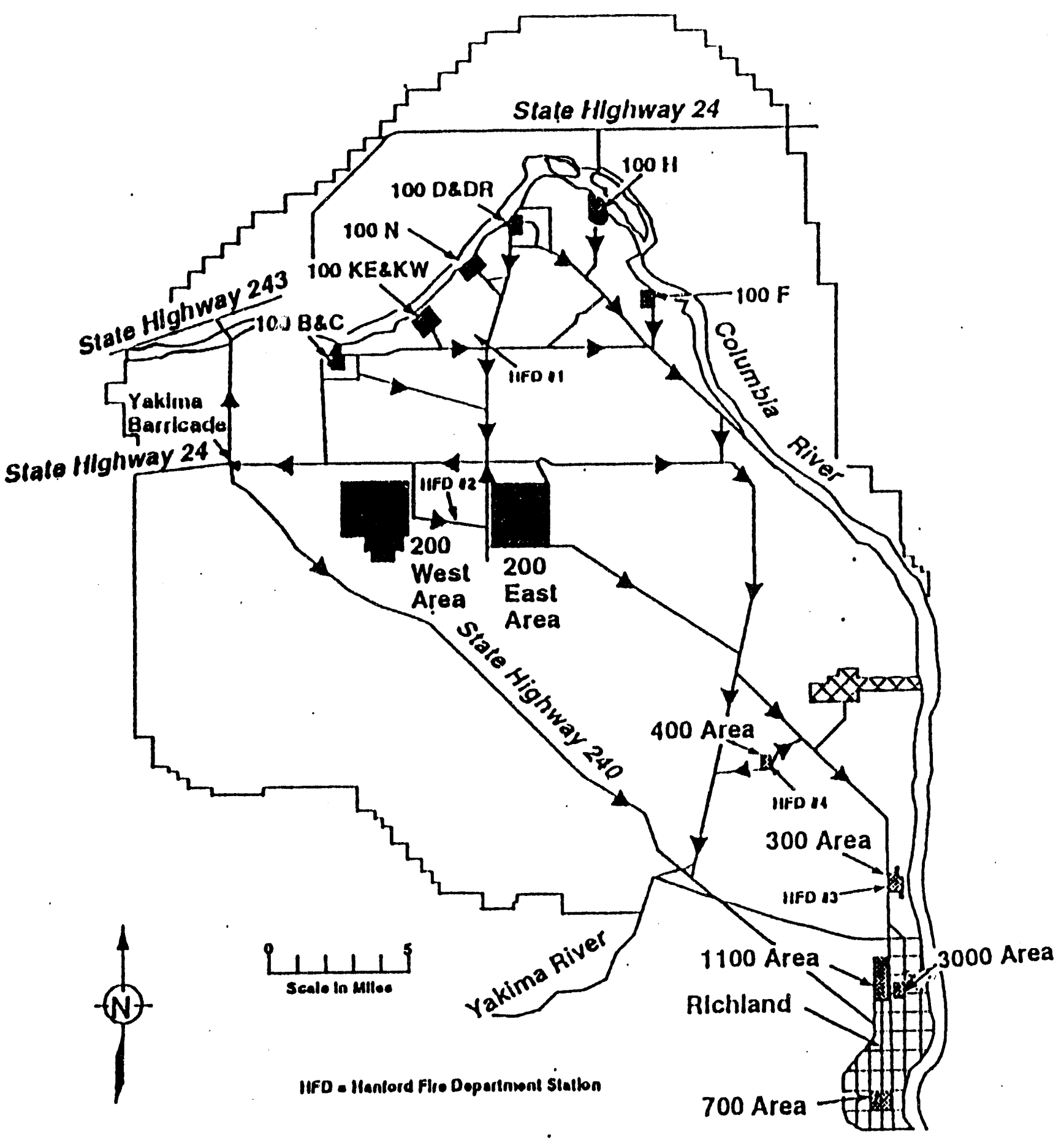

29200007.1

Figure 1. Hanford Facility Evacuation Routes and Locations of the Fire Stations on the Hanford Facility. 
Table 1. Emergency Control Centers.

\begin{tabular}{|l|}
\hline Emergency Control Center \\
\hline Northern Area Emergency Control Center \\
\hline Location: 2750-E, 200 East Area
\end{tabular}

\begin{tabular}{|l|} 
\\
\hline $\begin{array}{l}400 \text { Area Emergency Control Center } \\
\text { Location: Fast Flux Test Facility, }\end{array}$ \\
\hline
\end{tabular}

Emergency Management Center

Location: 1170 Building

Geographic area of responsibility: 400 Area.

Area of responsibility:

Responsible for the remaining 600 Area not covered by the area ECCs, assisting area ECCs, coordinating the Facility-wide response to emergencies, and serving as the focal point for other Hanford Site contractors and DOE-RL during emergencies. emergency situations involving the DOE-RL and/or contractor personnel, ensuring direct interface with all offsite agencies for mitigation and protection of offsite populations, facilities, and the environment.

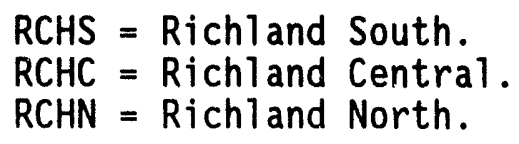


Table 2. Hanford Facility Alarm Systems.

\begin{tabular}{|c|c|c|}
\hline Signal & Meaning & Response \\
\hline $\begin{array}{l}\text { Crash Alarm } \\
\text { Telephones } \\
\text { (steady ringing } \\
\text { phone) }\end{array}$ & $\begin{array}{l}\text { Emergency } \\
\text { message }\end{array}$ & $\begin{array}{l}\text { Lift receiver, do not speak, listen } \\
\text { to caller and relay message }(\mathrm{s}) \text { to } \\
\text { building occupants and BED or } \\
\text { alternate. }\end{array}$ \\
\hline Gong (2 gongs/second) & Fire & $\begin{array}{l}\text { Evacuate building. Move upwind. } \\
\text { Keep clear of emergency vehicles. }\end{array}$ \\
\hline Siren (steady blast) & $\begin{array}{l}\text { Area } \\
\text { evacuation }\end{array}$ & $\begin{array}{l}\text { Proceed promptly to accountability } \\
\text { area. Follow instructions. }\end{array}$ \\
\hline Wavering Siren & Take cover & $\begin{array}{l}\text { Close all exterior doors, turn off } \\
\text { all intake ventilation and notify } \\
\text { manager of whereabouts. Request call } \\
\text { back for status and monitor portable } \\
\text { radios. }\end{array}$ \\
\hline Howler (AA-00-GAH) & Criticality & $\begin{array}{l}\text { Immediately run to the nearest exit } \\
\text { and move and remain at least } 100 \text { feet } \\
(30.5 \text { meters) from the building. }\end{array}$ \\
\hline
\end{tabular}


Table 3. Fire Department Equipment List. (sheet 1 of 3 )

3

\begin{tabular}{|l|l|l|}
\hline \multicolumn{1}{|c|}{ Equipment } & \multicolumn{1}{|c|}{ Description } & \multicolumn{1}{c|}{$\begin{array}{c}\text { *Norma11y } \\
\text { Located }\end{array}$} \\
\hline Engines & $\begin{array}{l}\text { Examples of equipment contained on } \\
\text { engines: }\end{array}$ & $\begin{array}{l}1 \text { at each } \\
\text { station }\end{array}$ \\
\hline Ladders & & Pumpers
\end{tabular}

8

4 Pumpers

- $1,500-2,000 \mathrm{gal} / \mathrm{min}(5,678.1-$ $7,570.8 \mathrm{~L} / \mathrm{min})$ pump

- 300-500 gal (1,135.6-1,892.7 L) portable tank

- Telescoping nozzle

- Jaws of Life.

Tankers

Tankers

Examples of equipment contained on tankers and pumpers:

6 Each

- $500 \mathrm{gal} / \mathrm{min}(1,892.7 \mathrm{~L} / \mathrm{min})$ pump

- 1,500 gal $(5,678.1$ L) tank

- $6 \times 6$ with 2,000 gal $(7,570.8 \mathrm{~L})$ porti-tank

- Hose, nozzles, fittings, and tools.

Water Tenders

Examples of equipment contained on water tenders:

1 Each

- $450 \mathrm{gal} / \mathrm{min}(1,703.4 \mathrm{~L} / \mathrm{min})$ pump

- 4,500 gal $(17,034.3 \mathrm{~L})$ tank

- Hose, nozzles, fittings, and tools.

Grass Fire Units

Examples of equipment contained on grass fire units:

1 at Station 1

2 at Station 2

1 at Station 4

2 at Station 3

- $100 \mathrm{gal} / \mathrm{min}(378.5 \mathrm{~L} / \mathrm{min})$ pump

- $250 \mathrm{gal}(946.3 \mathrm{~L})$ tank

- 4-wheel drive

- Hose, nozzles, fittings, and tools.

\begin{tabular}{|l|l}
\hline Ambulances & Exam \\
\hline
\end{tabular}

5 Each

Examples of equipment contained on ambulances:

- Life support systems

- Medical supplies and emergency response supplies.

\begin{tabular}{|l|l|l|l}
\hline Command Vehicles & Contains communications equipment and & Station 2
\end{tabular}

3 Each protective equipment for commander. 
Table 3. Fire Department Equipment List. (sheet 2 of 3)

\begin{tabular}{|c|c|c|}
\hline Equipment & Description & $\begin{array}{l}\text { * Normally } \\
\text { Located }\end{array}$ \\
\hline $\begin{array}{l}\text { Attack Vehicles } \\
1 \text { Each }\end{array}$ & $\begin{array}{l}\text { Examples of equipment contained on } \\
\text { attack vehicles: } \\
\text { - } 450 \mathrm{lb}(204.1 \mathrm{~kg}) \text { of purple-k } \\
\text { - } 300 \mathrm{gal}(1,1335.6 \mathrm{~L}) \text { aqueous film- } \\
\text { forming foam concentrate } \\
\text { - } 300 \mathrm{gal}(1,135.6 \mathrm{~L}) \text { of aqueous } \\
\text { film-forming foam pre-mix solution } \\
\text { - Hose, nozzles, fittings, and } \\
\text { tools. }\end{array}$ & Station 2 \\
\hline $\begin{array}{l}\text { Hazardous } \\
\text { Materials } \\
\text { Vehicle } \\
2 \text { Each }\end{array}$ & $\begin{array}{l}\text { Examples of equipment contained on } \\
\text { hazardous materials vehicle: } \\
\text { - Protective clothing for Hazardous } \\
\text { Materials Response Team } \\
\text { - Breathing apparatus for Hazardous } \\
\text { Materials Response Team } \\
\text { - Diking, plugging, and damming } \\
\text { equipment } \\
\text { - Detection instruments for } \\
\text { Hazardous Materials Response Team } \\
\text { - Tools for plugging and repairing } \\
\text { leaking containers } \\
\text { - Overpack containers for leaking } \\
\text { containers } \\
\text { - Command module with material } \\
\text { safety data sheets, software, and } \\
\text { portable meteorological station } \\
\text { - Tools and communications devices } \\
\text { necessary to provide } \\
\text { communications during emergency } \\
\text { response activities. }\end{array}$ & $\begin{array}{l}1 \text { at Station } 2 \\
1 \text { at Station } 3\end{array}$ \\
\hline $\begin{array}{l}\text { Metal Fire } \\
\text { Response Vehicle } \\
1 \text { Each }\end{array}$ & $\begin{array}{l}\text { Examples of equipment contained on } \\
\text { metal fire response vehicle: } \\
\text { - Equipment for response to special } \\
\text { metals fire } \\
\text { - } 5001 \mathrm{~b}(226.8 \mathrm{~kg}) \text { of extinguishing } \\
\text { powder } \\
\text { - } 1,0001 \mathrm{~b}(453.6 \mathrm{~kg}) \text { of carbon } \\
\text { microspheroids. }\end{array}$ & Station 4 \\
\hline
\end{tabular}


Table 3. Fire Department Equipment List. (sheet 3 of 3)

3

\begin{tabular}{|l|l|l|}
\hline \multicolumn{1}{|c|}{ Equipment } & \multicolumn{1}{|c|}{ Description } & \multicolumn{1}{|c|}{$\begin{array}{c}\text { *Normally } \\
\text { Located }\end{array}$} \\
\hline $\begin{array}{l}\text { Mobile Air } \\
\text { Vehicle }\end{array}$ & $\begin{array}{l}\text { Examples of equipment contained on } \\
\text { mobile air vehicle: }\end{array}$ & Station 4 \\
1 Each & $\begin{array}{l}\text { Mobile air compressor, recharges } \\
\text { self-contained breathing apparatus } \\
\text { cylinders } \\
\text { Tools and fittings for operation } \\
\text { of vehicle and spare cylinders. }\end{array}$ & \\
\hline
\end{tabular}

*The Hanford Fire Department Chief has the authority to direct the

placement of Fire Department equipment as needed to control emergency events. The Hanford Fire Department Chief also has the authority to take pro-active action and assign different vehicle locations based on such conditions as fuel moisture content, area fire history, work in progress, or other conditions that could arise.

$$
\text { gal }=\text { gallon(s) }
$$

gal $/ \mathrm{min}=$ gallon(s) per minute

$\mathrm{kg}=\mathrm{kilogram}(\mathrm{s})$

$L \quad=1 \operatorname{liter}(s)$

$\mathrm{L} / \mathrm{min}=1 i \operatorname{ter}(\mathrm{s})$ per minute

$1 \mathrm{~b}=\operatorname{pound}(\mathrm{s})$ 


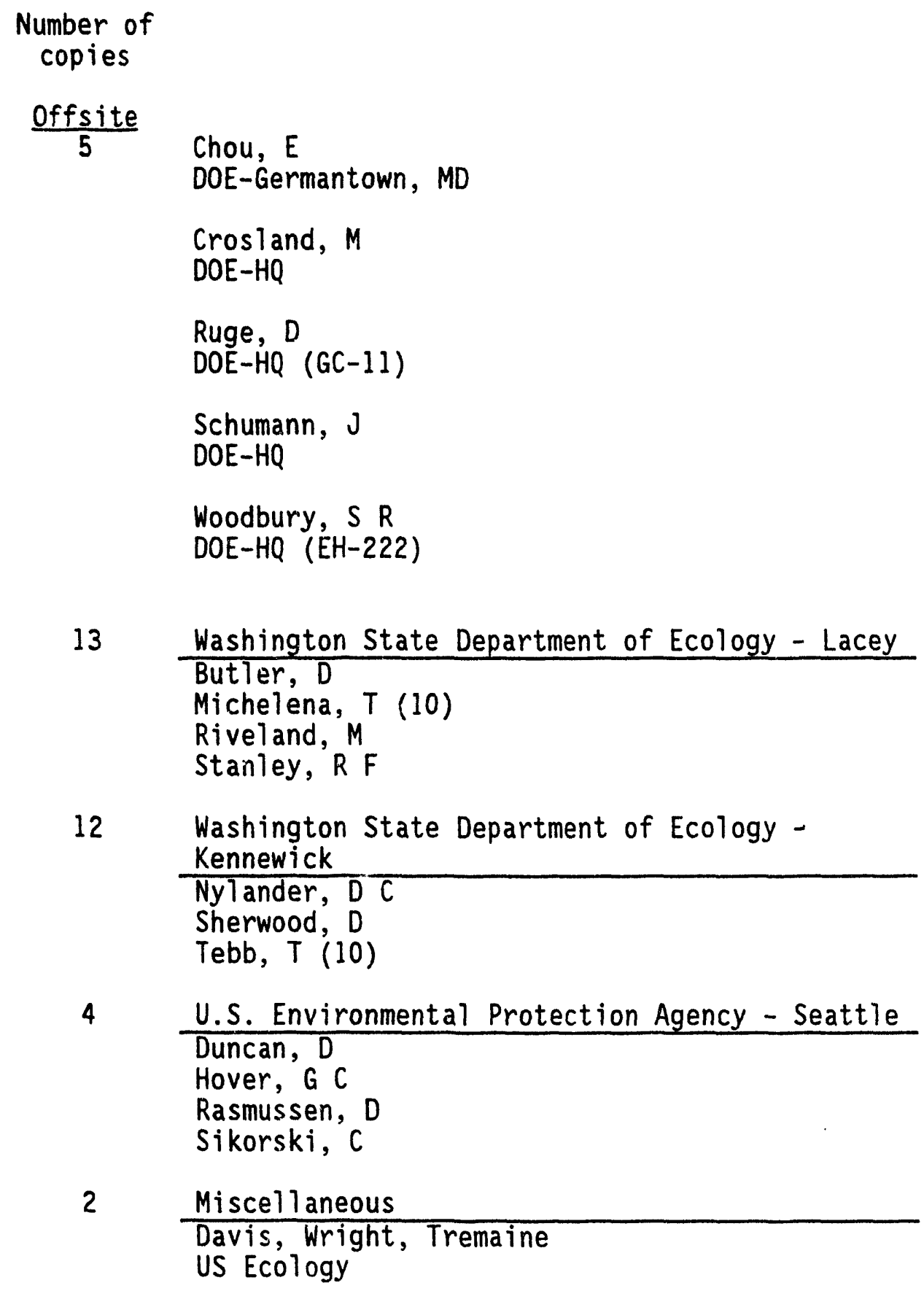

$\underline{\text { Onsite }}$ Richland Operations Office Beard, A V Bowers, EM Brown, D A A5-90 Carosino, R M R3-81 Chin, WS Clark, C E (5) A4-52 A5-18 Dev, M 
$\mathrm{DOE} / \mathrm{RL}-91-28$

Distribution

Guercia, R F Huffman, L A

R3-80

Kasch, C K

Kreke1, R N

Larson, R D

Lijek, S J (2)

Rasmussen, $J E$

A5-16

A5-55

A5- 15

A7-80

A4-35

Rodriguez, A L

A5- 15

A5- 15

Stewart, R K

A5- 19

Thomas, N G

A7 -27

Willison, PW

A4-52

Public Reading Room

$\mathrm{H} 2-53$

1 Kaiser Engineers Hanford Company

Dixon, B J

G7-33

14 Pacific Northwest Laboratory

Bjorklund, WJ

Bohn, L R

Broussard, D S

P7-68

Day, B J

Epperly, V P

Gephart, R E

Miller, $P L$

Minton, $B$ A

Poston, $\mathrm{K} \mathrm{A}$

Slater, H W

Thornton, G T

Tilden, $H T$

Turner, P J

Webster, K S

Hanford Technical Library

K1-67

P7 -68

P7 -63

$\mathrm{K} 1-22$

$\mathrm{K} 6-26$

$\mathrm{P} 7-72$

P8-01

P7 -40

P7 -68

P7 -68

P7-34

P8-45

K1-11

167 Westinghouse Hanford Company

Adams, MR (ECO)
Adler, J G
Albin, S E
Aldrich II, L K
Baker, R L (ECO)
Barnes, B M
Barron, D L
Bennington, T L
Bhatia, R K
Bolls, RE
Bowman, RC
Broomfield, B J
Brown, R W
Brown, L C
Brown, J F
Brown, G S
Brown, D W
Brunke, R C

H6-01

H6-23

T1-06

L8-16

S4-65

H6-24

S2-12

$\mathrm{H} 4-16$

H6-23

N3-13

$\mathrm{H} 6-24$

N3-13

L6-79

H6-20

G1-40

L6-53

N3-06

H6-24 
Burnside, $M E$

G2-02

Butcher, D P

$\mathrm{H} 6-23$

Calihan, $T W$

G2-02

Carlson, $G B$

G2-06

Carlson, A B

H5-49

Clark, M L

Clifford, S B

P7 -68

Cline, $M W$

H6-23

Clogston, $G L$

H6-24

$\mathrm{H} 2-18$

Coenenberg, $J$ G

$\mathrm{H} 6-24$

Cook, S A

SO-07

Cox, W G

H6-23

Darling, N E

H6-21

Dixon, W $T$

B2-17

Dutt, D S (ECO)

L6-39

Ehlis, J J

T2-10

Eide, $\mathrm{JH}$

G2-02

Engelmann, R H (5)

H6-26

Erlandson, B G

H6-20

Estey, L J

T5-20

Evans, G C

$\mathrm{H} 6-24$

Farquhar, D J (ECO)

A1-05

Field, J G

Fields, J L

Fox, R D

G2-02

H6-24

Fredenburg, E A

H6- 07

Freeman, $\mathrm{P} J$

S4-55

Fritz, Jr., DW

H6-06

H6-30

Gamin, JE

G6-57

Gano, K A

$X 0-21$

Garrison, H L

H5-38

Gasper, K A

Geier, C J

R2-08

H6-21

Gilchrist, SM

L6-26

Girres, C K

Greager, E M

Gretsinger, W T (ECO)

N3-13

H6-30

Grygiel, M L

R4-01

Gunter, P R (ECO)

B] -58

S2-46

R3-50

Hadley, K A

B4 -53

Hale, N S

T5-30

Halgren, D L (ECO)

S6-70

Hall, M J (ECO)

T6-12

Hare, DE

S3-97

Hawkins, A R

Hencke1, R P

L4-85

Hendrix, M S

H6-02

$\mathrm{H} 4-23$

Hendrix, R T

H6-23

Herman, D R

S2-66

Hill, R C

B4-53

Hoff, D J

H6-23 
Hookfin, R W

H6-30

Hoover, $J D$

$\mathrm{H} 6-23$

Hopkins, G G

N3-06

Hydzik, K M

L4-93

Jackson, $R$ L

H6-06

Jansky, M T

N2-53

Jensen, $R D$

A2-50

Jones, $R L$

N3-05

Jutian, R J (ECO)

T3-28

Kasper, J R (ECO)

R2-50

Kirkenda11, J R

$\mathrm{H} 4-21$

Knox, K E

$\mathrm{H} 6-24$

Koerner, J A

S6-70

Korematsu-01und, D M

$\mathrm{H} 6-23$

La Barge, $M J$

Landeen, $G H$

H6-30

Landon, $R \mathrm{~J}$

H6-23

Larue, $\mathrm{J} H$

H6-22

Lauterbach, M J

G6-16

Law, R L

H6-0I

Laws, J R

B1-61

LeBaron, $G J$ (ECO)

H6-23

Legore, $T$

Lucas, C D

Luke, $S \mathrm{~N}$

Mackey, P J

Maier, B

Marple, C E (ECO)

S6-19

B4-63

$\mathrm{X} 0-35$

H6-23

B3- 15

T4-06

Marsh, D A

B4-52

A3-05

McBride, D J (ECO)

T5-54

Mcleod, R G

A5- 19

Miller, P C (ECO)

N2-04

Moak, D J

N3-05

Moist, S L

Montgomery, L M

N3-05

Morton, M R (ECO)

H6-08

Moss, K J (ECO)

R2-77

Nichols, D H

01dham, R W

R3-12

$\mathrm{H} 4-21$

H6-25

Parker, D L

Petersen, S W

$\mathrm{H} 6-03$

H6-23

Petersen, K L

H4-14

Petkevicius, F R

B2-30

Pierce, R D (ECO)

N3-13

Poor, A D (ECO)

G4-10

Pope, Jr., R B

B5-21

Powers, $L L$ (ECO)

L4-96

Price, WH

N3-05

Price, S M

H6-23

Prignano, A L

$\mathrm{H} 6-23$

Quayle, T A

H6-22

Retterer, W A

S2-20 
DOE/RL-91-28

Distribution

Ring, $J M$

H6-30

Rogers, $L$ (ECO)
Romsos, M R

S3-97

N3-11

Ruck, $F A$

$\mathrm{H} 6-23$

Saueressig, D G

H6-24

Schanke, M T

Schmid, J S

Schmidt, J P (ECO)

B2-16

Silva, R R

H6-06

XO-41

Smith, EH

$\mathrm{H} 4-14$

Speer, D R

$\mathrm{H} 6-22$

St Georges, L L

$\mathrm{R} 1-48$

Stevenson, $M W$

XO-21

Steward, J C

$\mathrm{B} 2-35$

Stocker, DE

H6-30

Sutton, $S C$

Szelmeczka, R W

Thompson, $S A$

Thompson, $R$ R

Toebe, WE

Tredway, M A (ECO)

G4-10

S2-37

T4-06

H6-24

ᄂ4-96

H6-22

R3-54

Vance, LW

H4-16

Vaughn, $\mathrm{J}$

Vitulli, M J

N3-06

$\times 0-35$

Votaw, EF (ECO)

G2-02

Waite, J L

Watson, $D \mathrm{~J}$

Weakley, E A

Welsch, J M

$\mathrm{B} 2-35$

$\times 0-41$

L6-26

L6-13

Williams, J D

R1-48

Williams Jr., J F

H6-24

Willis, N P

N3-11

Zoric, J P

Correspondence Control (Denise)

Environmental Data Management Center (2)

ERC

$\times 0-21$

H6- 08

H6-07

Information Release Administration (3)

$\mathrm{H} 4-14$ 

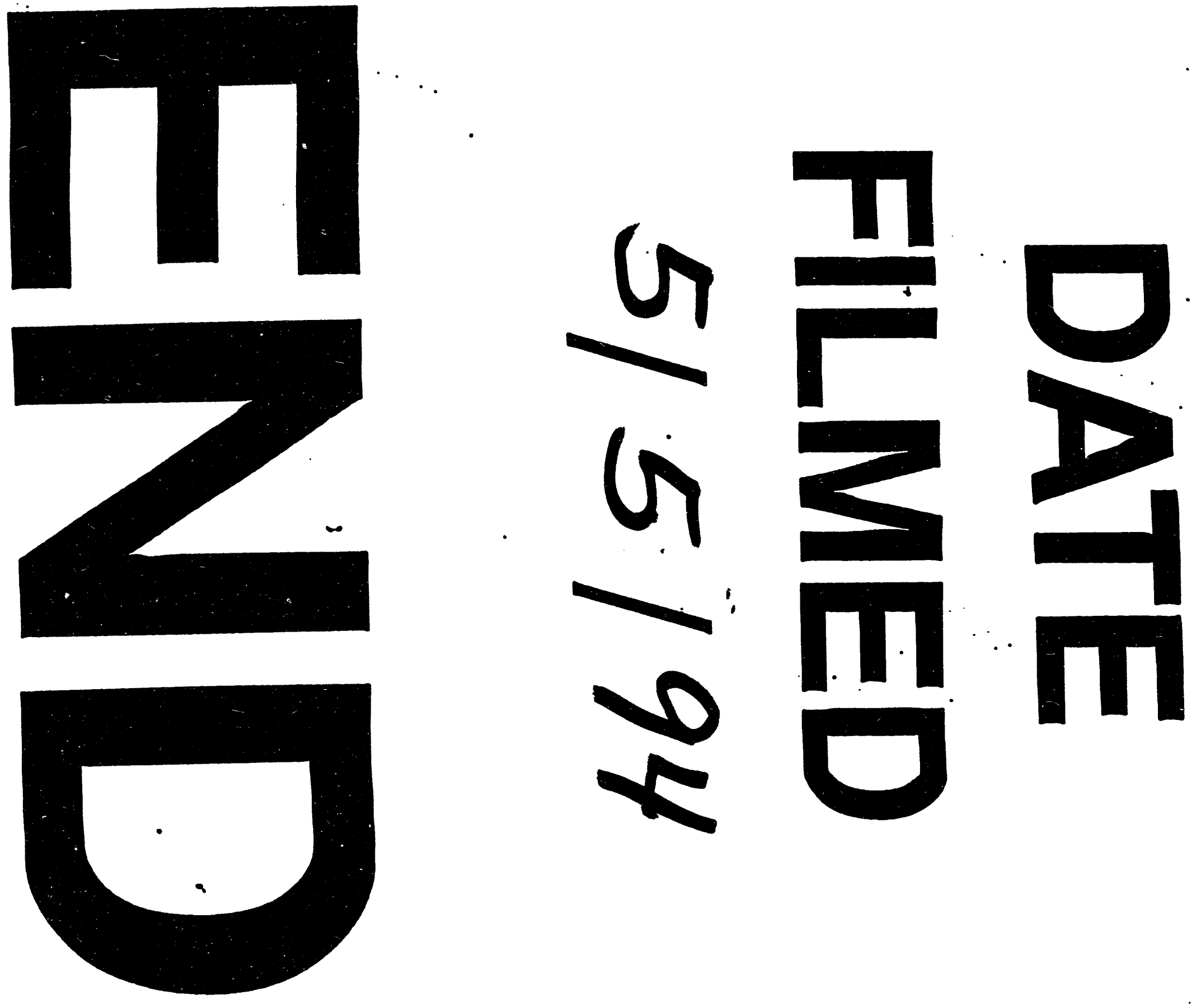